
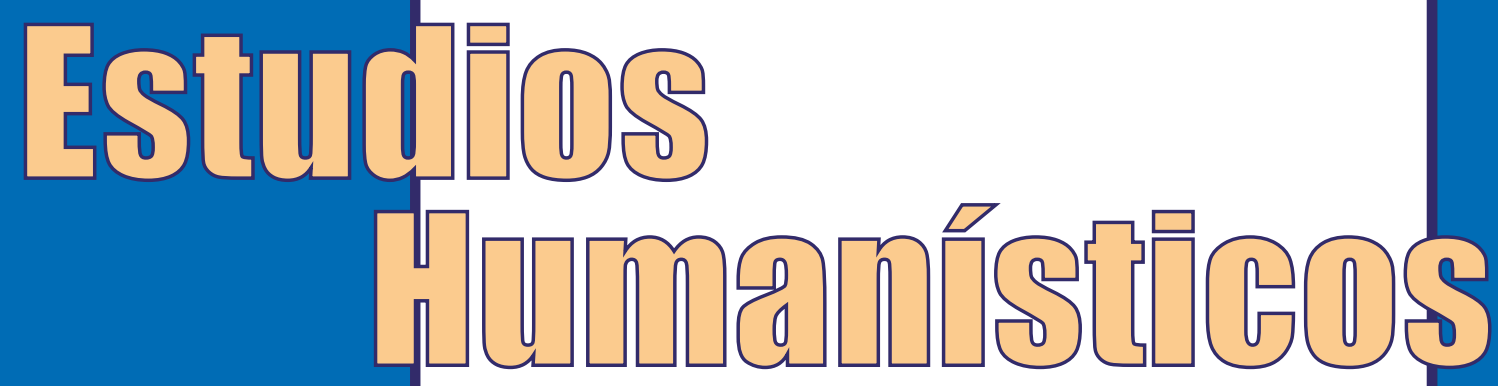

ப)
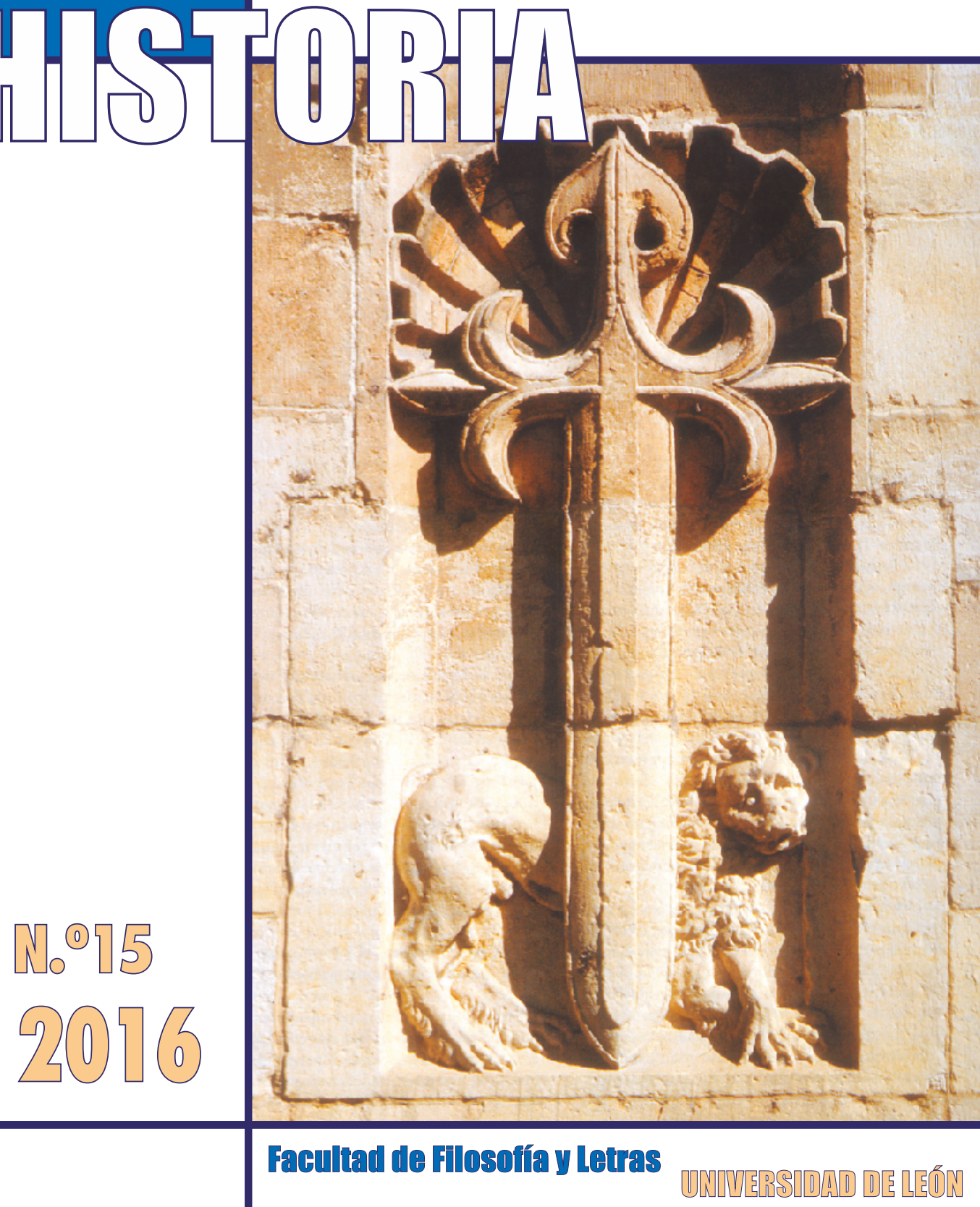


\section{NORMAS PARALOS AUTORES}

1. Los Artículos han de ser inéditos y originales. Tendrán una extensión de entre 20 y 30 páginas a doble espacio, con un máximo de 70.000 caracteres (unas 10.000 palabras), incluidos cuadros, gráficos, notas, apéndices y bibliografía.

2. La extensión de las Notas Científicas y metodológicas no podrá superar los 18 folios, con un máximo de 45.000 caracteres (unas 6.400 palabras).

3. Las Aportaciones de investigadores noveles incluirán trabajos de investigadores no doctores, que el consejo de redacción considere relevantes. No podrán superar los 18 folios, con un máximo de 45.000 caracteres (unas 6.400 palabras) y en cada número no se podrá acoger más de tres colaboraciones de este tipo.

4. Las Reseñas y noticias bibliográficas se recomienda que no superen la extensión máxima de tres folios.

5. En cada número se incluirán, además de las informaciones que puedan resultar relevantes, los resúmenes de las tesis doctorales vinculadas al departamento de Historia, que deberán remitir los doctorados; su extensión no superará los cuatro folios.

6. Cada trabajo irá precedido de una hoja donde figurarán el título, nombre del autor o autores, titulación, centro al que está vinculado, dirección postal, dirección de correo electrónico (los datos particulares no serán publicados). Además cada contribución incluirá el título en inglés y dos resúmenes -máximo 100 palabras- en castellano e inglés. Asimismo, se indicarán las palabras clave en ambos idiomas.

7. Las colaboraciones podrán remitirse en cualquiera de las lenguas oficiales de la Unión Europa(UE).

8. Sólo se aceptarán apéndices documentales breves, para su publicación en Notas científicas y metodológicas.

9. Las notas de los respectivos trabajos deberán ir numeradas correlativamente, en caracteres arábigos, voladas sobre el texto e insertas a pie de página. Se realizarán en el mismo formato que las referencias bibliográficas.

10. Las referencias bibliográficas observarán el siguiente formato:

Libros:

TOPOLSKY, J. (1973). Metodología de la Historia. Madrid: Cátedra, p. 50.

Contribuciones en volumen colectivo:

BURGE, G. (1986). "El problema del desarrollo histórico". En Álvarez, J. y Huyeres, T. (eds). Temas y conceptos para pensar la Historia. Madrid: Anthropos, pp. 117-136.

Artículos de revista:

ÁLVAREZ, M. (2003). "Métodos para establecer los hechos históricos". Estudios Humanísticos. Historia, 16, pp. 35-50.

Recursos en línea:

RODRIGUEZ BRAVO, B. ALVITE DÍEZ, M. L. (2005). Survey of the providers of electronic publications holding contracts with spanish university libraries [recurso electrónico]. D-Lib Magazine, 2005, vol.11, nº 4. <http://www.dlib.org/dlib/april05/alvite/04al> [Consultado:12-11-2008].

11. Las ilustraciones, gráficos, cuadros, etc., deberán ir numerados en caracteres arábigos y acompañados de pie identificativo, con cita de la fuente.

12. La Secretaría de la revista acusará recibo de los trabajos en el plazo de diez días a partir de la fecha de su recepción. Tras la pertinente evaluación, se comunicarála resolución del Consejo de Redacción a los interesados.

13. Los autores recibirán pruebas de imprenta para su corrección, debiendo proceder a su revisión en un plazo máximo de diez días.

\section{REQUISITOS DEEDICIÓN}

A fin de facilitar las tareas de edición/impresión, se encarece la observación de las siguientes pautas:

1. Los trabajos se enviarán en soporte informático y podrán estar realizados sobre cualquier versión de Microsoft Office o sistema abierto compatible. El envío ser realizará preferiblemente a través de la plataforma OJS de la Universidad de León. También pueden enviarse por correo electrónico a la secretaría de la Revista.

2. De forma preferente, se entregarán en un solo archivo, ajustados a tamaño de página DINA4 con los márgenes predeterminados que aparecen por defecto al crear un nuevo archivo de Word. En ningún caso debe modificarse el margen de encuadernación, que ha de ser cero (0).

3. Se utilizará como fuente Times New Roman, tamaño 12 puntos, pudiendo variar este patrón en función de los distintos niveles jerárquicos del texto.

4. No se recomienda el empleo de símbolos o signos procedentes de fuentes de origen alfabético cirílico, griego y, en general, las de procedencia oriental. En caso de necesidad, los textos de esa naturaleza deberán de ser procesados como imágenes. Para destacar palabras o textos se usará exclusivamente cursivas, no negritas ni subrayados.

5. En caso de remisión de imágenes, deberán incrustarse, no vincularse, en el documento. Aeste respecto, se recomiendan el empleo del formato JPG, la inserción en blanco y negro y su preferente agrupación en las páginas finales. Siempre que sea posible, los archivos que contengan imágenes usadas en el documento se entregarán junto con el mismo.

6. Por acuerdo de 28 de febrero de 2007 se ha decido difundir la revista en DIALNET a texto completo, de manera que, al enviar sus colaboraciones, los autores se comprometen a aceptar este medio de difusión electrónica

\section{PROCESO DE SELECCIÓNYEVALUACIÓN DE LOS ORIGINALES}

Los trabajos deberán someterse a las normas de edición mencionadas, de no ser así se devolverán a sus autores para su adaptación.

Todos los estudios serán sometidos a la evaluación confidencial de dos expertos externos. En caso de que los evaluadores propongan modificaciones, será responsabilidad del Consejo de redacción verificar la reelaboración del estudio. De no ser aceptado para su publicación, el original será devuelto a su autor junto con los dictámenes emitidos por los evaluadores.

El Consejo de Redacción se compromete a dar cuenta a los autores de la decisión de publicar o no su trabajo en tiempo y forma.

\section{ACCESO ABIERTO}

Una vez publicados sus trabajos -y nunca antes- los autores podrán difundirlos por otros medios (repositorios, web personal, etc.) siempre que indiquen claramente la referencia bibliográfica dela Revista, e incluyan un enlace activo a la web de la misma. 


\section{ESTUDIOS HUMANÍSTICOS \\ HISTORIA}

$N^{0} 15$ - 2016

ISSN: 1696-0300

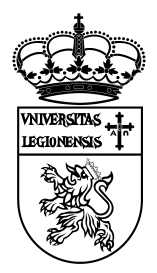

Revista del Departamento de Historia

Universidad de León

León, 2016 


\section{ESTUDIOS HUMANÍSTICOS. HISTORIA \\ Revista del Departamento de Historia \\ Universidad de León}

DIRECTORA

Matividad Fuertes Prieto - (Universidad de León)

SECRETARIO

Carlos Fernández Rodríguez - (Universidad de León)

\section{CONSEJO DE REDACCIÓN}

\begin{tabular}{|c|c|}
\hline Gregoria Cavero Domínguez (ULE) & Mauricio Herrero Jiménez (UVA) \\
\hline Julio Escalona Monge (CSIC) & Juan Francisco Jiménez Alcázar (UM) \\
\hline Óscar Fernández Álvarez (ULE) & Ofelia Rey Castelao (USC) \\
\hline Ma Encarnación Martín López (ULE) & Jorge Sánchez-Lafuente Pérez (ULE) \\
\hline M José Pérez Álvarez (ULE) & Susana Sueiro Seoane (UNED) \\
\hline Blanca Rodríguez Bravo (ULE) & José Viriato Capela (UMINHO) \\
\hline Carlos Sen Rodríguez (ULE) & \\
\hline
\end{tabular}

\section{COMITÉ CIENTÍFICO}

José Manuel Abascal Palazón (Universidad de Alicante) José Ramón Aja (Universidad de Cantabria)

Luis Álvarez Munárriz (Universidad de Murcia) Juan Manuel Abascal palazón (Universidad de Alicante)

Pedro Cardim (Universidade Nova de Lisboa) Juan Manuel Carretero Zamora (Universidad Complutense) Gérard Chastagnaret (Université de Aix-en-Provence) David González Cruz (Universidad de Huelva) Klaus Herbers (Universidad Erlangen-Nürnberg) Bruno Laffort (Université de Besançon)
José Lucio Mijares Pérez (Universidad de Valladolid)

José Antonio Moreiro González (Univ. Carlos III de Madrid)

Rodrigo Moreno Jeria (Universidad Adolfo Ibáñez de Chile)

Manuel Redero San Román (Universidad de Salamanca)

Gerardo F. Rodríguez Universidad Nacional de Mar del Plata)

Ioan Piso (Universidad de Cluj)

Andrew Reynolds (London University College)

David Ruiz González (Universidad de Oviedo)

Diana Soto Arango (Rudecolombia)

Estudios Humanísticos. Historia, aparece, entre otras, en las siguientes bases de datos: Catálogo Latindez, ISOC. Historia, REBIUN, DIALNET, DICE, INRECH, REGESTA, IMPERII y CIRC.

Sumarios electrónicos:http://revpubli.unileon.es/index.php/EEHHHistoria; DIALNET

Envío de artículos:

SECRETARÍA DE ESTUDIOS HUMANÍSTICOS. HISTORIA

Departamento de Historia - Facultad de Filosofía y Letras - Universidad de León 24007 León

e-mail: ulecreh@unileon.es

Suscripciones e intercambios

Área de Publicaciones - Edificio de Servicios - Campus de Vegazana s/n - Universidad de León - 24007 León

$$
\text { Periodicidad: anual }
$$

Contenido:

Estudios Humanísticos - Historia, es una revista científica de Historia que acepta trabajos originales de investigación de todas las etapas históricas en cualquier idioma de la UE. Tiene una periodicidad anual y los artículos recibidos son evaluados por revisores externos mediante el sistema de doble ciego. También acepta revisiones bibliográficas, notas, comunicaciones y otras noticias sobre estudios históricos.

(C) Universidad de León - Área de Publicaciones

(C) Los Autores

e-ISSN: 2444-0248 - ISSN: 1669-300

Depósito Legal: LE-565-2003

Maquetación y preimpresión: Juan Luis Hernansanz Rubio - Área de Publicaciones de la Universidad de León 


\section{SUMARIO}

\section{Sección I. MONOGRÁFICO}

\section{J.M. BARTOLOMÉ BARTOLOMÉ Y M. GARCÍA FERNÁNDEZ (COORDS.) CONSUMOS DE APARIENCIA EN LA CASTILLA MODERNA}

Bartolomé Bartolomé, Juan Manuel, García Fernández, Máximo. Presentación. Consumos de apariencia en la Castilla moderna.

Blanco Carrasco, José Pablo. Sedas, rasos y damascos en la casa del Conde de Benavente (C. 1533).

GARCÍA HERAS, Víctor Alberto. El pan y el oro. Consumo diferenciado en la ciudad de Cuenca durante la guerra de sucesión española

GIORGI, Arianna. Sastres y roperos en Madrid. La imagen cotidiana de la moda del siglo XVIII.

GARCÍA FERnÁNDEZ, Máximo. Vestidos pobres: consumos estancados. Valladolid en el siglo XVIII

BARTOLOMÉ BARTOLOMÉ, Juan Manuel. Vestir los cuartos y el cuerpo en el clero regular masculino: los canónigos de San Isidoro de León (1700-1825).....

BIRRIEL SALCEDO, Margatita M. ¿Un consumo imprescindible? El traje femenino en las cartas de capital del Valle de Lecrín (1730-1770).

CRESPO SÁNCHEZ, Francisco Javier. Vestidos y adornos: la crítica a las apariencias externas a través de la prensa española (finales del siglo XVIII - siglo $X I X)$

Roso DíAz, José. Vestimenta, moda y sociedad en la comedia española de buenas costumbres.

\section{Sección II. ESTUDIOS}

FERNÁNDEZ MENÉNDEZ, Mercedes. La respuesta patronal durante la Restauración ante los accidentes laborales en una empresa minera. El caso de la Sociedad Anónima Minas de Riosa (Asturias, 1899-1916).

RODRÍGUEZ YunTA, Luis. Difusión y evaluación de la investigación histórica en la era digital: revistas españolas y bases de datos. 


\section{Sección III. INVESTIGADORES NOVELES}

LI, Chenguang. "A vos el poderoso y muy estimado Rey de la China". Primera Embajada Regia de Felipe II con destino a la China de la dinastía Ming: origen, preparación y abandono....

\section{Sección IV. RESEÑAS Y NOTICIAS BIBLIOGRÁFICAS}

García Hurtado, Manuel-Reyes y Rey CAStelao, Ofelia (eds.), Fronteras de agua. Las ciudades portuarias y su universo cultural (siglos XIV-XXI), Santiago de Compostela: Universidade de Santiago de Compostela, 2016, 570 p. ISBN: 978-8416533-87-9, por María José PÉREZ ÁlVAREZ

ApaOlaza LloRente, Dorleta, Los bandos de buen gobierno en Cuba. La norma y la práctica (1730-1830), Vitoria: Servicio Editorial de la Universidad del País Vasco, 2016, 719 págs., ISBN: 978-84-9082-400-9, por Jesús PANIAGUA PÉREZ

\section{Sección V. OTRAS INFORMACIONES}

BARRIONUEVo AlmuZARA, Isabel. La fotografía en León (1839-1900). Director: Dr. Francisco Carantoña Álvarez. Tesis doctoral defendida el 5 de febrero de 2016 277

GARCÍA FUERTES, Arsenio. La decisiva participación de los $6^{\circ}$ y $7^{\circ}$ ejércitos españoles en el triunfo aliado en las campañas de 1811 y 1812 durante la Guerra de la Independencia. Director: Dr. Francisco Carantoña Álvarez. Tesis doctoral defendida el 15 de enero de 2016.

Lagartos Pacho, Francisco Javier. Población, sociedad y familia en Tierra de Campos leonesa. La comarca de Sahagún en el s. XVIII. Director: Dr. Juan Manuel Bartolomé Bartolomé. Tesis Doctoral defendida el 21 de enero de 2016

MARTínez PÉREZ, David. Construyendo la democracia. Tardofranquismo, transición política y la cuestión autonómica en la provincia de León (1962-1984). Director: Dr. Francisco Carantoña Álvarez. Tesis doctoral defendida el 28 de enero de 2016

Revilla CASADO, Javier. La economía de posguerra en la provincia de León (1937-1953): El Servicio Nacional del Trigo, los molinos y las fábricas de harinas. Los años del hambre y del estraperlo. Director: Dr. D. José Javier Rodríguez González. Tesis doctoral defendida el 19 de enero de 2016

Unanue Cuesta, Ma Concepción. Antropología del Género. Identidad sexual y géneros alternativos: un estudio sobre la homosexualidad femenina. Director: Dr. Óscar Fernández Álvarez. Tesis doctoral defendida el 21 de enero de 2016 
Sección I: MONOGRÁFICO 



\title{
CONSUMOS DE APARIENCIA EN LA CASTILLA MODERNA
}

\author{
JUAN MANUEL BARTOLOMÉ BARTOLOMÉ \\ Departamento de Historia, Universidad de León (León) \\ jmbarb@unileon.es \\ MÁXIMO GARCÍA FERNÁNDEZ \\ Universidad de Valladolid - IUHS \\ mgarcia@fyl.uva.es
}

Los estudios sobre el consumo han evolucionado desde unos planteamientos iniciales más económicos (De Vries, 2009; Torras, 1999; Maruri, 2003) a otros de orientación eminentemente social y de civilización (Ago, 2006; Muñoz, 2011; Bartolomé, 2012; García, 2013; Pérez-García, 2013), poniendo el acento en los enseres e indumentarias demandadas y en la dinámica de las cantidades consumidas, pero también en el quién, cómo y dónde se consumían, aspectos todos ellos claves para poder aproximarnos a la reconstrucción de las identidades culturales tejidas en la Europa Occidental durante la Edad Moderna. De la fábrica, la feria y la tienda, al mostrador, el escaparate y la revista de modas, en suma. Así, en la actualidad, lo que interesa son las líneas de investigación que podemos denominar visiones horizontales del consumo; es decir, la adopción por parte de diferentes familias o grupos de individuos, hasta en espacios planetarios muy alejados, de diversas prácticas consumistas o una demanda contrastada de productos originarios de otras latitudes más o menos conectadas. Partiendo de esa idea motriz, y sin olvidar tales objetivos, tratamos de seguir analizando dicho proceso desde miradas comparadas más próximas y cercanas al interior castellano urbano.

El proceso reformador ilustrado y las nuevas formas de la sociabilidad burguesa paseos, visitas, bailes, juegos de mesa, etcétera- impulsaron y aceleraron la llegada de una concepción de la casa y de los espacios domésticos más moderna, favoreciendo la extensión de la privacidad. En paralelo, se estimulaba la demanda de nuevos productos, destinados tanto a una mayor comodidad y notoriedad de las residencias privadas como también a la adecuación pública de las vestimentas (con sus accesorios más visibles) y de unas apariencias personales externas parejas a aquellas modificaciones socioculturales. 
Siguiendo esas premisas claves y dentro de las líneas prioritarias de nuestro proyecto de investigación en curso $^{1}$, el monográfico que ahora se presenta es el resultado de una profunda reelaboración de los trabajos defendidos y ampliamente discutidos en la concurrida Sesión paralela $\mathrm{n}^{\circ}$ 6, celebrada dentro del XI Congreso de la Asociación de Demografía Histórica (Cádiz, junio de 2016), que llevaba por estimulante título de debate: Familias y consumo en Europa entre 1600 y 1850. Interiores domésticos y apariencias externas.

Esquemáticamente y profundizando en esas innovadoras líneas de investigación vigentes y metodológicamente más en boga, estos ocho artículos tienen como principal nexo de unión el análisis del contraste de las apariencias externas, focalizadas en el atuendo y el adorno de los cuerpos. En ese recorrido cronológico y temático, los puntos de atención inciden tanto en los consumos de ostentación notoria de los estratos más elitistas de la primera mitad del siglo XVI (Blanco bucea en el viaje que el conde de Benavente realizó en compañía de la emperatriz Isabel al objeto de recibir al emperador a su llegada a Barcelona, punto focal capital donde expresar con esplendor y rotundidad el fasto y el poder de toda la alta nobleza castellana lucido en sus ropajes), mientras García Heras analiza las demostraciones textiles diferenciadas según las distintas familias y grupos en pugna por acercarse y controlar el poder cortesano capitalino a comienzos del Setecientos en la ciudad de Cuenca durante la Guerra de Sucesión, pasando por algunos interesantes dimorfismos estéticos presentes en el a priori más homogéneo hábito del clero regular masculino (según el trabajo de Bartolomé sobre los canónigos de la Colegiata de San Isidoro de León), hasta valorar los enseres y pertenencias propias de los sectores populares mayoritarios durante el siglo XVIII (García Fernández compara la ausencia de consumo en los ajuares portados por los enfermos del Hospital de la Resurrección de Valladolid o a través de los numerosos legados testamentarios de ropas, en franca disparidad con los rasgos modernizadores del vestir masculino y femenino presentes en las grandes ciudades y en la Corte; o se trata de comprender el simbolismo exhibido en los trajes más característicos y mantenidos secularmente inventariados en las cartas de capital del valle de Lecrín, en la provincia de Granada, entregados públicamente por los varones a las novias con motivo de la celebración de sus esponsales, examinados por la doctora

${ }^{1}$ Proyecto investigador financiado: Civilización, juventud y cultura material e inmaterial. Familia e identidad social. Demandas y apariencias en la Castilla interior. 1500 - 1850; Ministerio de Economía y Competitividad de España, 'Retos', 2014-2017 (HAR2013-48901C6-3-R). 
Birriel). Esas imágenes se tornan más completas y evidentes tras el estudio de las vestimentas guardadas en sus casas y vendidas en sus tiendas por los propios sastres y mercaderes del activo sector ropero capitalino madrileño (Giorgi), complementadas además con las sugerentes aportaciones que toman como eje de referencia la extensa literatura editada en aquella época sobre la polémica generada por la moda y las formas de lucir, con no pocos excesos, el aparato indumentario en la comedia dieciochesca de buenas costumbres (Roso). Finalmente, tampoco podían faltar las constantes y celebradas críticas vertidas desde la embrionaria prensa española letrada al lujo, a las vanidades mujeriles y, en general, al exagerado peso del universo de boato y el oropel extranjerizante (Crespo).

Se trata así de ofrecer una nueva panorámica que muestre la modernización del vestuario masculino y femenino así como la evolución de las manifestaciones culturales de la indumentaria como símbolo de pobreza, de necesidad de apariencia o de poder, síntesis de muchos de los rasgos más sobresalientes de la mentalidad enraizada en la Castilla interior (pasando por Madrid y hasta cubrir la exteriorizada en tierras granadinas). Tanto entre grupos sociales minoritarios como para los sectores populares rurales; una notoriedad tan buscada como criticada; retratada o impresa; con notables efectos económicos y hasta políticos; visible en una cronología amplia y desde fuentes documentales muy diversas; en un tenso proceso estético de aceleración integrador, aunque con prácticas muy contrastadas, que acabó convertido en un modelo de civilización occidental impuesto, al menos, en la sociedad urbana española.

Así lo acaba de poner de manifiesto también el doctor Maruri en una excelente y recientísima síntesis de planteamientos historiográficos y de recorrido metodológico sobre los que seguir investigando, a la que remitimos ${ }^{2}$.

En definitiva, con estas aportaciones se sigue demostrando que, sin olvidar la importancia de cuantificar los objetos, debe tenderse también a la valoración de sus múltiples significados (económicos, de estatus, de edad, de género, de apariencia, de demostración, de moda, de modernidad, de afrancesamiento, de tradicionalismos...) para responder con más conocimiento de causa a la cuestión capital de la existencia o no de una revolución del consumo (McKendrick, 1982) pareja a otra revolución de las apariencias (Roche, 1989) en la España y en la Europa de la Edad Moderna.

León, a 24 de noviembre de 2016

\footnotetext{
${ }^{2}$ Ramón Maruri Villanueva, "La historia social del consumo en la España Moderna: un estado de la cuestión”, Estudis. Revista de Historia Moderna, 42 (2016), pp. 267-301.
} 



\title{
SEDAS, RASOS Y DAMASCOS EN LA CASA DEL CONDE DE BENAVENTE (C. 1533)
}

\section{SILKS, SATINS AND DAMASK FABRICS IN THE HOUSE OF THE COUNT OF BENAVENTE (C. 1533)}

\author{
JOSÉ PABLO BLANCO CARRASCO \\ Departamento de Historia, Universidad de Extremadura \\ blanco@unex.es
}

Recibido: 26/09/2016

Aceptado: 20/12/2016

RESUMEN: Las pautas de consumo de las familias castellanas cambiaron a medida que se consolidaron dos procesos descritos por la historiografía reciente. Por una parte, el aumento del capital disponible. Por otra, la llegada al reino de productos de lujo procedentes de los principales centros manufactureros de la época. El efecto que esta transformación tuvo en la sociedad es múltiple. Con esta comunicación intentaremos mostrar la magnitud de esta intensificación en las economías nobiliarias, tomando como ejemplo la casa condal de Benavente a principios del siglo XVI.

PALABRAS CLAVE: Consumo, conde de Benavente, gastos de representación.

ABSTRACT: The consumption patterns of Castilian families changed in the 16th century as two processes described by recent historiography were consolidated. On the one hand, the increase in available capital. On the other, the arrival to the kingdom of luxury products from the main manufacturing centers of the time. The effect of this transformation on society is manifold. With this paper, we will try to show the magnitude of this intensification in the nobiliary economies, taking as an example the house of Benavente in the early 16th century.

KEYWORDS: Consumption, Count of Benavente, representation expenses.

\section{INTRODUCCIÓN}

El consumo de las familias durante el siglo XVI conoció dos fenómenos paralelos. Por una parte, el aumento de productos provenientes de la importación disponibles en el mercado. Por otro lado, un incremento del poder adquisitivo de determinados sectores de la población que animó consecuentemente este proceso. Ambos elementos forman parte de la trayectoria económica de la primera Edad Moderna en Castilla, cuyos trazos resultan cada vez mejor conocidos. 
A pesar de las novedades, conviene subrayar algunas características que no se modificaron sustancialmente. Es sabido que una parte considerable de los ingresos familiares se destinaban a la supervivencia -alimentación, siembra, vestido...- ${ }^{1}$. Esa es posiblemente la tónica general de las pautas de consumo de la mayoría de los habitantes del reino, es decir un gasto que gira alrededor de las necesidades diarias de la supervivencia familiar ${ }^{2}$, periódicamente comprometida por las variaciones climáticas y las crisis de subsistencia, sobre todo en el mundo rural antes que en las florecientes villas y ciudades castellanas ${ }^{3}$. Sin embargo, en las contabilidades familiares de los umbrales de la modernidad aparecen con mayor frecuencia que en épocas anteriores productos que podríamos considerar relacionados con el consumo suntuario ${ }^{4}$. Si hacemos caso de la literatura de la época y de las escrituras notariales conservadas, uno de los escenarios en donde ese cambio se hizo más patente es la vestimenta ${ }^{5}$, tal como advierten en múltiples ocasiones historiadores de la cultura que ven como la ropa es usada para identificar con un sencillo golpe de vista la posición social que ocupa el que las porta ${ }^{6}$.

Además del consumo de telas y adornos de lujo en la $\mathrm{Corte}^{7}$, la trascendencia de la generalización del uso de confecciones consideradas de lujo en un sector más amplio

${ }^{1}$ M. GARCÍA FERNÁNDEZ (2011). "Lujos y penurias populares: enseres cotidianos y cultura material en el Quinientos”. Biblioteca: estudio e investigación, 26, pp. 25-47.

${ }^{2}$ A. MARCOS MARTÍN (2000). España en los siglos XVI, XVII y XVIII. Economía y sociedad. Barcelona: Crítica, p. 41.

${ }^{3}$ F. COMÍN, M. HERNÁNDEZ y E. LLOPIS (Eds.) (2003). Historia económica de España. Siglos $X-X X$. Barcelona: Crítica, p. 49-53.

${ }^{4}$ M.A. LADERO QUESADA (Coord.) (2004). El mundo social de Isabel la Católica. La sociedad Castellana a finales del siglo $X V$. Madrid: Dikynson. En torno al problema que describimos, vid. en especial los trabajos de Álvaro Fernández de Córdova Miralles sobre la Corte y el entorno cortesano y María Concepción Quintanilla Raso sobre los grandes nobles. (A. FERNÁNDEZ DE CÓRDOVA MIRALLES: "Sociedad cortesana y entorno regio" en Ladero Quesada, M.A. (coord.) op. cit. pp. 49- 78 y C. QUINTANILLA RASO: "Los grandes nobles" en Ibid pp. 127-142).

${ }^{5}$ N. DE DIEGO Y GONZÁLEZ y A. LEÓN SALMERÓN (1915). Compendio de indumentaria española, Madrid, 1915, p. 107 y ss. (Ed. fascímil, 2011, Valladolid: MAXTOR).

${ }^{6}$ M. GARCÍA FERNÁNDEZ (2012): "Consumo e identidad cultural urbana europea en el largo periodo de transición hacia la contemporaneidad”. Revista de historiografía, 16, pp. 129-140.

${ }^{7}$ En un texto clásico ya exponía que la Corte no era sólo un lugar donde se tomaban decisiones políticas. Se comportaba, en cierto modo, como un escenario difusor de tendencias en el vestir, el protocolo social y el ocio. (M. FERNÁNDEZ ÁLVAREZ (2001). "El siglo XVI. Economía. Sociedad. Instituciones" En Historia de España Menéndez Pidal. Madrid: Espasa Calpe, T. XIX, p. 318). 
de la sociedad de la época es un hecho descrito por las fuentes ya en los inicios del siglo XVI. El cambio de gustos de las mujeres y los hombres de las élites locales, eminentemente urbanas, en cuanto a las vestimentas y los aderezos que las adornan, y el impulso de las nuevas modas vivido por sus familias, produjo un efecto en los hábitos de consumo que ha sido objeto de estudio central de los historiadores de la cultura y la historia social, poniendo el objetivo en el papel difuminador que esta transformación tenía en las rígidas fronteras estamentales todavía vigentes a finales de la Edad Media ${ }^{8}$. El surgimiento de cierto individualismo diferenciador no puede alejarse de este proceso9 9

Los principales consumidores de lujo en la España del siglo XVI son los nobles cortesanos. A diferencia de los cortesanos que rodeaban a Enrique IV y los Reyes Católicos, un noble en el siglo XVI necesita disponer a su alrededor de un número creciente de elementos destinados a su distinción, no solo para identificarse como tal ante el resto de la sociedad, sino para distinguirse dentro de su propio estado, es decir, en relación con su mismo grupo social esencialmente. Dos de los ámbitos de la representación en los que este cambio se da con más claridad e intensidad van a ser, primero, el de la apariencia que irán adoptando las clases más altas de la escala social, y después, aunque conectado en cierta forma con el anterior, el de la proliferación de sirvientes y criados a su alrededor. Norbert Elias lo subrayaba en un texto esencial: "la elaboración diferenciada de lo externo, como instrumento de la diferenciación social (...) es característica esencial de la vida cortesana"10.

Algunos textos recientes dejan claro el proceso -sin abundar en él- del incremento del gasto en economía simbólica de la nobleza. Gastos que son inversión, tal como vienen explicados por las fuentes, pues su sentido se justifica tanto desde dentro como desde fuera del estamento. Durante el siglo XVI y en el XVII se da un proceso de enclasamiento -por utilizar el término empleado por Bourdieu ${ }^{11}$, que acerca a miembros destacados del común, formalmente al menos, a los representantes de la pequeña y media nobleza local y provincial. En estos grupos, el proceso de identificación con la forma noble de vida, en especial en las indumentarias y las formas de vestir, genera alrededor de esta dinámica un debate que nos conduce a la

\footnotetext{
${ }^{8}$ Ibid.

${ }^{9}$ R. VON DÜLMEN: El nacimiento del individualismo. Madrid: Siglo XXI, 2016.

${ }^{10}$ N. ELÍAS (1982). La sociedad cortesana. México: Fondo de Cultura Económica, p. 187.

${ }^{11}$ P. BOURDIEU (2002). La distinción. Criterios y bases sociales del gusto. México: Fondo de Cultura Económica.
} 
importancia de las apariencias y la representación por encima de las teorías jurídicas en torno a la identidad de la nobleza ${ }^{12}$. En cualquier caso, el proceso determina que el rango debe ser alimentado contantemente de representaciones, de etiquetas, y de forma urgente en una época de rápido ascenso social de grupos ajenos al estamento.

¿Dicho proceso afecta por igual a las grandes y a las pequeñas familias nobles? Sí, ciertamente, pero en muy diferente medida. Los más perjudicados son los representantes de la nobleza local, los hidalgos, los pequeños caballeros, un referente universal para una parte de la población que es mayoritariamente rural y campesina. Ambos grupos, en especial los primeros, se empiezan a ver sobrepasados en rentas y prestigio social por comerciantes y rentistas de todo tipo, labradores notorios, ganaderos dueños de las bases productivas locales. El fenómeno es esencialmente urbano, pero las posiciones de prestigio de los "hombres de tratos" tienen en muchos casos, origen rural.

A pesar del empuje de estos grupos sociales en ascenso, en la mentalidad imperante en la época (segunda mitad del siglo XV, primera mitad del XVI), la notoriedad de la hidalguía es reconocida inequívocamente en el ámbito geográfico inmediato como un elemento de prestigio social, independientemente de sus rentas. López de Gómara al retratar a la familia de Hernán Cortés, dice de ellos que "tenían poca hacienda, empero mucha honra, lo cual raras veces acontece si no es en personas de buena vida, y no solamente los honraban sus vecinos por la bondad y cristiandad que conocían en ellos, sino que hasta ellos mismos se preciaban de ser honrados en todas sus palabras y obras, por lo que vinieron a ser muy bienquistos y amados de todos"13. Fama pública y buena opinión, al margen de la riqueza, dos elementos indispensables y constantes para encajarles socialmente, porque en la España de finales del siglo XV, la familia de los hidalgos representa a un grupo social bien definido, la pequeña nobleza rural, con rasgos originales derivados del momento político que se vivía en esos años, pero por ese motivo también, una época en la que era posible medrar al servicio de un noble de mayor rango o, mejor aún, ganar prestigio, honra y fortuna al servicio del rey. Esta idea caló en una parte de la población que aspiraba a la nobleza -o a formas alternativas de prestigio- y se veía desplazada del centro social, como los grandes labradores, los ganaderos rentistas o los mercaderes urbanos, pero también en aquella porción de los nobles que no podían acompañar su forma de vida con una inversión constante y

12 J.A. GUILLÉN BERRENDERO (2012). La Edad de la Nobleza. Identidad nobiliaria en Castilla y Portugal (1556-1621). Madrid: Polifemo, pp. 30-149.

${ }^{13}$ F. LÓPEZ DE GÓMARA: La conquista de México. (Ed. 2008 Linkgua Digital). 
creciente en gasto social. En efecto, son años de cambio en la mentalidad de la propia nobleza. De hecho, cuando López de Gómara quiere describir en pocas palabras la posición social que disfrutaba Cortés -en este caso- menciona primero la hacienda, la fortuna familiar, sus rentas, para después compensar su poca cuantía con una honra colmada, reconocible entre los miembros de su comunidad y signo visible de la identidad de la familia hidalga. Y lo hace interesadamente, porque, a pesar de todo, tal como indica M.-C. Gerbet, a finales del siglo XV en el reino de Castilla, "la gloria no bastaba si no engendraba fortuna, y el prestigio de un linaje estaba en función de su riqueza" ${ }^{14}$, una idea que refuerza las palabras que en este sentido escribiera en el Espejo de la verdadera nobleza Diego de Valera, entre otros, para quien era evidente la pérdida de importancia del concepto de virtud -patrimonio de la nobleza-a la hora de definir al noble en la época.

El cuestionamiento de la nobleza aparente se comenzó a dar en torno al proceso de enriquecimiento de los grupos sociales más pujantes en la España del Quinientos. En efecto, la pérdida de posiciones sociales del estamento nobiliario venía alentando un debate sobre sus funciones que encontraba en el cuestionamiento que manejaban las clases pecheras sobre la verdadera nobleza, un motivo para la discordia, pues nunca se generó un verdadero problema social al respecto, del que están alejados los grandes linajes cortesanos. La respuesta fue el incremento del gasto destinado a la diferenciación social para seguir manteniendo la visibilidad del rango como elemento de diferenciación social ${ }^{15}$. Éstos, a diferencia de las tensiones reproducidas a escala por la pequeña nobleza comarcana o señorial -que gira en torno a una corte estatal con su propio sistema gravitacional al estar encabezada por un gran noble territorial-, están intentando encontrar un sitio distinguido en la compleja corte que se organiza en los reinos hispánicos simultáneamente alrededor de Fernando II de Aragón, el Católico, la reina Juana de Castilla y el emperador Carlos V. En este contexto de cambios de poder, de vértigo para muchas casas señoriales, se impuso en España el estilo de corte borgoñona, algo más que un cambio de vestuario, un cambio de orden.

En este contexto de cambio, que afecta a todo el estamento, las grandes casas nobiliarias jugaban su partida en un escenario relativamente independiente, donde

\footnotetext{
${ }^{14}$ M.-C. GERBET (1989): La nobleza en la corona de Castilla. Sus estructuras sociales en Extremadura (1454 1516), Cáceres: Diputación Provincial de Cáceres.

${ }^{15}$ A. ÁlVAREZ-OSSORIO ALBARIÑO (1998-1999). "Rango y apariencia. El decoro y la quiebra de la distinción en Castilla (SS. XVI-XVIII). Revista de Historia Moderna, 17, pp. 263278.
} 
confluyen la ampliación del Estado con la aparición en Castilla de reglas y etiquetas nuevas. La llegada al trono de Carlos, coronado en Castilla en 1516, hizo que se impusiese un complejo sistema de casas que, a su vez, devino en la coexistencia de distintos protocolos hasta la final generalización de las normas del protocolo y estructura de la corte de Borgoña, que fue la que el joven monarca había seguido en Flandes ${ }^{16}$. El conflicto Comunero dejó en evidencia el papel integrador de la Corte y la Casa del Esperador y en 1523 éste inició un proceso de hispanización que culminará con la ocupación por grandes nobles castellanos de los cargos que les garantizaban la cercanía del monarca, en correspondencia con la importancia capital de Castilla en el conjunto de la monarquía. Al final de su vida, en 1558, Carlos estaba rodeado por cuatro quintas partes de gentilhombres y hombres de cámara castellanos. Ello impuso un cambio importante en las estrategias familiares de muchas de estas casas nobles, que vieron aumentado su rango en la misma medida que sus inversiones en lujo y representación.

Sin embargo, la imposición de la casa de Borgoña en Castilla no implicaba cambios necesariamente urgentes en las formas de vestir y actuar de toda la nobleza. De la misma manera, la adaptación a los nuevos estilos llegados con Carlos $\mathrm{V}$ aconsejaba un cambio en la moda y en la apariencia de los cortesanos y, tras de sí, la de toda su casa. Sin embargo, a pesar de la progresiva instauración de la etiqueta borgoñona, por primera vez impuesta a partir de la llegada a Castilla de Isabel de Valois (1559-1560), de los nuevos gustos en la sociedad aristocrática castellana, en el reino coexistieron diferentes estilos y modas hasta la homogeneización vivida ya durante el reinado de Felipe II ${ }^{17}$.

\section{LUJO Y APARIENCIA: EL CONDE DE BENAVENTE, SU CASA Y SU SÉQUITO.}

Ejemplos de lo que indicamos en las líneas anteriores, en los que se expresan con esplendor y rotundidad el fasto y el poder de la alta nobleza, son fruto tanto de su forma de vida como de sus estrategias políticas; dos de las manifestaciones de rango y ostentación de forma más llamativa y colorista, son la comitiva y la fiesta cortesana ${ }^{18}$.

16 J. MARTÍNEZ MILLÁN (2011). "Corte y casas reales en la Monarquía Hispana: la imposición de la Casa de Borgoña" Obradoiro de Historia Moderna, 20, pp. 13-42.

17 C. BERNIS MADRAZO (1962). Indumentaria española en tiempos de Carlos V, Madrid: CSIC.

${ }^{18}$ En contraste con la imagen de sobriedad que se convierte en emblema de la corte hispana, el colorido de las vestimentas representa un ambiente festivo. A. GIORGI (2016). España se viste 
Hemos escogido para recrearlas el viaje que el Conde de Benavente realizó en compañía de la emperatriz Isabel con objeto de recibir al emperador a su llegada a Barcelona después de la guerra de Italia, y una serie de justas y torneos que se celebraron de camino a Valladolid, ciudad de residencia del Conde ${ }^{19}$, en el viaje de regreso. En el documento que nos sirve de base se encuentran detallados los gastos que el conde Antonio Alonso de Pimentel realizó en telas, mayoritariamente sedas y terciopelos, aproximadamente en los años treinta del siglo XVI, al servicio del emperador Carlos en bastantes ocasiones, pero también con objeto de decorar estancias privadas o servir de vestido para el propio conde, amigos o miembros de su séquito y de su familia ${ }^{20}$.

La posición de los condes de Benavente fue muy favorable durante el reinado de Carlos I, tanto la de Alonso de Pimentel, como la de su hijo Antonio Alonso, II y III condes de Benavente. En torno a su casa y a la del Conde de Aguilar giraba uno de los principales resortes de la monarquía carolina en sus primeros instantes, y esa lealtad nunca fue olvidada por el monarca, que favoreció a estos linajes con numerosas prebendas y beneficios. Una política de cercanía que, sin embargo, debía cuidarse y

a la francesa. La historia del traje de moda de la segunda mitad del siglo XVII. Murcia: Editum, p. 23.

${ }^{19} \mathrm{El}$ establecimiento preferente de la corte en Valladolid atrajo a la ciudad a numerosos nobles de diferente condición y burgueses ansiosos por conectar con el monarca, esencialmente aquellos que tienen señoríos cercanos a la villa. El conde de Benavente, la cuarta fortuna del reino a mediados del siglo, es propietario de Villalón y Cigales, entre otras; en su mismo lugar está el Almirante de Castilla, con ingresos por valor 170.000 ducados, respecto de Medina de Rioseco, de la que es duque: "[...] el favor del monarca tuvo otra repercusión, también muy estimable para la villa: el hacer de ella una de sus residencias preferidas, la monarquía a trajo a las orillas del Pisuerga, como ya hemos visto, a muchos grandes señores o hidalgos muy ricos..." B. BENNASSAR (1983): Valladolid en el siglo de Oro. Una ciudad de Castilla y su entorno agrario en el siglo XVI. Valladolid: Ayuntamiento de Valladolid, p. 123. Obviamente, en pos de estas fortunas, no tardará en llegar un mercado local orientado a los productos de lujo. Una nota ilustrativa de este hecho en Ibid. p. 126.

${ }^{20}$ Archivo Histórico Nacional (AHN). Sección Nobleza, OSUNA, Caja 422, Exp.72. Se trata de un documento contable, no fechado, posiblemente realizado con el objetivo de llevar un registro detallado de las piezas de tela adquiridas por el sastre Juan Note, destinadas a los arreglos y confecciones que éste realizó para el conde, su séquito y un conjunto heterogéneo de personajes a los que el conde quería agasajar con vestidos y prendas de lo más variado. En él Juan Note da cuenta de tallada de las piezas de seda y paño que utilizó en estas composturas, sin mencionar el precio de cada una de ellas, por lo que no parece probable que se trate de un documento del Libro de cuentas o Despensa típico de las administraciones nobiliarias, sino de un expediente anterior, informativo, y, quizás por ello, plagado de detalles. 
potenciarse y que, por lo tanto, obligaba a los condes a invertir enormes cantidades de dinero para mantener sobre ellos la atención y el favor del emperador. Fruto de esta confianza mutua fue la posición en la corte de la emperatriz, instalada en Valladolid, a la que Carlos dejaba al cuidado del conde durante sus largas ausencias, encomendándole tareas solo reservadas para personas muy cercanas $\mathrm{y}$, naturalmente, con medios económicos suficientes para acometerlas con éxito.

Una de estas ocasiones la brindó el viaje de bienvenida que la emperatriz emprendió para recibir a Carlos $\mathrm{V}$ tras su estancia en Italia, algo más de cuatro años después de su salida. En 1529 partió el emperador Carlos desde Barcelona tras siete años de residencia en el reino de Castilla. La situación en Italia era insostenible para los intereses de la familia real. Salió del puerto de Barcelona, atestado de naos, urcas y chalupas de la armada imperial; afuera quedaban las galeras de la armada que habían venido con Andrea Doria, en una de cuyas naves, ricamente cubierta con toldos de raso y seda, se alojará Carlos V. El espectáculo en el puerto era seguido por miles de personas seguramente impresionadas por el despliegue de colores, sonidos y artefactos que acompañaban el largo embarque, concebido en sí mismo como un espectáculo público más que como una aséptica maniobra de guerra. Su destino, Génova. Con él viajaban ya muchos caballeros castellanos y aragoneses, los cuales, según testimonio de Prudencio Sandoval, se mostraron ante el gentío que esperaba en el puerto "con gran demostración de sus riquezas, en sus casas y en las libreas que llevaban”21.

Allí, en la capital del condado, confluyeron los grandes que acompañarían al emperador en el viaje. De las palabras de Sandoval se deduce que sus respectivas llegadas a la ciudad, por mar o por tierra, estaban preparada y diseñadas para impactar en el espectador. En la comitiva se ordenaba la sociedad noble de forma jerárquica; la ostentación de la riqueza y el poder del grupo era evidente:

"Venían luego los caballeros principales de todas naciones, duques, condes, marqueses, varones, gobernadores, capitanes, hijos y hermanos dellos, donde venía toda la riqueza del mundo, de los adereços de sus personas y caballos, de oro y de plata, de piedras y de perlas, brocados de telas de oro y recamados; y bien poco menor la de sus pajes y lacayos. Tras ellos iban los ballesteros de maça, y los reyes de armas del Emperador ${ }^{22} \ldots "$

${ }^{21}$ SANDOVAL, P. de (1625). Historia de la vida y hechos del emperador Carlos V. Libro III, pp. 53 y 54 .

${ }^{22}$ SANDOVAL, P. de: Historia ... op. cit. pp 68-69. 
El alarde que se vivió en esos días permitía a los nobles hacer uso de sus pendones de seda y tafetán, mostrar el rango de sus casas a través de sus criados, ricamente ataviados, de sí mismos y de sus caballos, engalanados como para iniciar un torneo. En aquella ocasión, cercana todavía la guerra de las Comunidades, con un poder en formación, el viaje era crucial tanto para los nobles que deseaban consolidar sus posiciones alrededor del monarca como por los problemas políticos y territoriales que pretendía acometer. La coronación definitiva, la difícil situación de Venecia y Florencia, el constante peligro vivido en el Mediterráneo, que se alargaría durante todo el reinado... Cinco años después de la partida, la vuelta a España del emperador tras su salida, a pesar de los fastos preparados para su llegada en la lengua de mar del puerto de Barcelona, no había asegurado la tranquilidad en todos los frentes abiertos.

Como era habitual, en este tiempo la emperatriz se había alojado en Valladolid, ciudad de residencia del Conde de Benavente y de un nutrido grupo de las principales familias aristocráticas del reino. El viaje de la emperatriz entre Valladolid y Barcelona para recibir al emperador en su regreso del primer viaje a Italia era una ocasión impagable para mostrar la grandeza de la casa de Benavente fuera de su escenario habitual, Valladolid, en cuyos festejos tenían siempre un papel destacado. Su residencia, en las márgenes del río, extramuros, era citada por todos los viajeros como una de las principales residencias de la villa y su presencia en la ciudad era constante. Por su posición y su fortuna el conde formaba parte principal del séquito de la reina y aunque no había podido participar activamente en la primea guerra de Italia, junto al emperador, sí su padre, titular del señorío, quien murió un año después de iniciadas las hostilidades que motivaban este viaje. No le faltarían ocasiones de señalarse, pues la casa de Benavente era, en la figura de su titular, una de las más queridas por Carlos I, leales desde su llegada y como, tales personajes muy cercanos al monarca. Por todo ello, estaban encargados de proporcionar a la emperatriz las comodidades necesarias para el largo viaje, una empresa nada desdeñable dado el creciente prestigio de Isabel de Portugal en Castilla al hacerse cargo de la gobernación del reino ${ }^{23}$. Para lograr sus fines, el conde de Benavente disponía de gran número de sirvientes, un grupo ordenado y eficaz que debía causar el mismo efecto ante la opinión pública, ante el espectador

\footnotetext{
${ }^{23}$ Acompañaban a la emperatriz, además de sus hijos Felipe y María, media nobleza de Castilla. M. FERNÁNDEZ ÁLVAREZ (1999): Carlos V. El César y el hombre. Madrid: Espasa Calpe, p. 468.
} 
de la comitiva, que un pequeño ejército en marcha ${ }^{24}$.

Obviamente, la comitiva no estaba pensada para pasar desapercibida, sino todo lo contrario. Los músicos se encargaban de difundir la noticia de la inminente llegada de la emperatriz a muy larga distancia, de manera que las autoridades y aristocracia locales estuvieran prevenidas y evitaran cualquier sombra de ofensa. Los cazadores y trompeteros, casi una treintena, debían acopiar alimentos para los participantes, cuyo número no podemos precisar, aunque posiblemente multiplicara por tres o cuatro veces el total de lo consignado en el cuadro siguiente si tenemos en cuenta el servicio que acompaña a la emperatriz y el del resto de los aristócratas que participaban en la comitiva $^{25}$.

${ }^{24}$ Esta demanda creciente de servicio se explica por varios motivos: los cambios que a lo largo de la baja Edad media y en la primera modernidad sufre este cuerpo social en concreto, una de cuyas consecuencias no es otra que la pérdida de prestigio de la nobleza en relación con grupos cuyo ascenso social es creciente, como ocurre con el patriciado urbano, los magistrados, los hombres al servicio de la administración del cada vez más complejo entramado estatal del monarca, etcétera. Este hecho significa en la práctica un aumento relativo del número de criados empelados en las casas de las élites locales. Desde el punto de vista de la nobleza, también se dan razones objetivas para aumentar el número y la especialización de los criados a su servicio, especialmente en los palacios en los que fijan su residencia, dada la complejidad creciente de sus administraciones y la necesidad constante de mantener a través de la apariencia, el rango social en el que viven instalados. Por último, en ausencia de un clima bélico y de sus amenazas, la proliferación de juegos públicos de guerra, rodeados de lujo y espectáculo, además de mantenerse desde antiguo como una dimensión habitual de su forma de vida, persigue, en cierta manera, la idea de alejar del olvido aquella naturaleza original propia de su estado sobre la que se fundan sus privilegios; dichas prácticas precisan de un enorme contingente de servidores directos e indirectos, muchos de ellos especializados en dotar a las familias nobles de un aspecto marcado por el lujo y la ostentación. Así pues, su estilo de vida les convierte en uno de los principales demandantes de servicios personales, porque una parte muy importante de sus actividades las ocupa el tiempo que su casa necesita dedicar a la representación social y la inversión en cierta economía simbólica, es decir, a la distinción. Bartolomé Bennasar advertía, en relación con los festejos que animaban el calendario de espectáculos en el Valladolid del siglo XVI que era "el momento soñado para exhibir brocados, adornos y caballos de raza, para que las gentes sencillas admiren la fuerza, la habilidad, el valor de sus nobles, y para acrecentar así su respeto hacia ellos”. B. BENNASSAR (1983): Valladolid en el siglo de Oro. Op. cit, p. 435.

${ }^{25}$ M J. REDONDO CANTERA: "La itinerancia de la Emperatriz Isabel de Portugal y de su recámara" en Cabañas Bravo, M. et al (coords.) (2011). El arte y el viaje. Madrid: CSIC, p. 484. 


\section{Cuadro 1. Criados al servicio del duque de Benavente en el viaje a Barcelona} (1533)

\begin{tabular}{|l|c|}
\hline \multicolumn{1}{|c|}{ Criados al servicio del Conde } & Número \\
\hline Pajes & 52 \\
\hline Lacayos & 18 \\
\hline Mozos de espuelas & 11 \\
\hline Mozos de galgos & 3 \\
\hline Otra gente (sic. $)^{26}$ & 6 \\
\hline Menestrales & 6 \\
\hline Atabaleros y trompeteros & 4 \\
\hline Trompetas & 9 \\
\hline Cazadores & 21 \\
\hline Cazadores pajes (capote) & 12 \\
\hline Acemileros & 17 \\
\hline Aguador & 1 \\
\hline Gallinero & 1 \\
\hline Mozos de copa & 5 \\
\hline
\end{tabular}

Fuente: AHN, Sección Nobleza, OSUNA, Caja. 422, Doc. 72. Elaboración propia.

El rango del conde debía hacerse notar además desde un punto de vista visual de manera efectista. La posición del personaje y su cercanía al monarca en cierta medida debían reflejarse en el lujo con el que se revestía y de ello da buena cuenta la descripción de las vestimentas y adornos confeccionados para la ocasión.

Para vestir a los lacayos y pajes fueron necesarias 42 varas de terciopelo. Se confeccionaron con ellas cincuenta y dos libreas y otras cuatro para los mozos de cámara. Los pajes fueron vestidos con grandes sayos, con la manga izquierda bordada de terciopelo verde y blanco y -tal como indica el documento que recoge la tela utilizada- "por guarnición dos fajas de terciopelo una blanca y otra verde, con sus pestañas de raso (de tafetán) blancos e verdes"27. En conjunto, tan sólo para el sayo de pajes y lacayos, Juan Note, el sastre del conde, empleó aproximadamente 90 varas de terciopelo verde y blanco ${ }^{28}$. Más de 50 varas del mismo terciopelo verde y blanco

\footnotetext{
${ }^{26}$ Entendemos, criados de servicio.

${ }^{27}$ AHN, Sección Nobleza, OSUNA, Caja 422, Doc. 72, f. 2

${ }^{28}$ En el libro de cuentas tomadas al contador Alonso Pérez de la tesorería de la casa de Benavente correspondiente al año 1536, aparece una entrada contable que refleja los pagos
} 
fueron usadas para confeccionar las capas de los pajes, que vestían un sayo idéntico al de los lacayos. La colorista legión de sirvientes que acompañaba a la comitiva se enriquecía con nuevos colores en función de la ocupación o los atuendos específicos de cada criado según la especialidad que tuviesen. Es de notar, que la mayor cercanía al señor implicaba inmediatamente un mayor lujo y vistosidad en el uniforme. Los 28 mozos de espuela se vistieron con sayos "de ruan y perpiñán anaranjado, que llevan dos fajas de terciopelo una blanca y otra verde, con sus pestañas de raso e tafetán sin la manga bordada". Sobre este uniforme, "28 capas de ruan anaranjado que llevan las dichas dos fajas de terciopelo blanco y verde, con pestañas de raso y tafetán por guarnición; entraron en las dichas 28 capas, a vara y tres cuartos en cada una en la dicha guarnición, que son 49 varas de terciopelo", cantidad que debe sumarse a las 49 varas anteriores.

Como se puede observar, la paleta de colores de la indumentaria era muy llamativa, un hecho que se agudiza con personajes singulares dentro del conjunto, como era el caso de Salsamón, un criado del conde para quien se hizo "una capa de terciopelo anaranjado con cuatro mangas, las dos para vestir y dos muy largas que fuesen colgando. (...) Entró en ella trece varas escasas de terciopelo e más llevaba por guarnición dos varas y sesma de terciopelo en dos fajas anchas con sus pestañas de raso, de manera que son quince varas y sesma de terciopelo" ${ }^{29}$. Además, se le confeccionó un capote de caza, éste de paño, como al resto de los cazadores, cuyo atuendo estaba compuesto básicamente por prendas del mismo tejido teñido de color anaranjado, sayos y capas, adornados con terciopelos verdes y blancos; los menestrales vestían "ropas" y "capillas flamencas con fajas de terciopelo muy anchas, aforradas

realizados al sastre Juan Note por parte del conde, en total, 14.000 maravedís, cantidad fija en la que posiblemente tenía apalabrado su contrato (AHN, Secc. Nobleza., Osuna, caja 424, doc. 23, fol. 42v.). Un documento de contrato privado formalizado entre el V Conde de Alba de Aliste y el sastre Sebastián Gutiérrez correspondiente a 1562 sugiere que las condiciones de la contratación incluían clausulas específicas que podrían variar los términos de la contratación en situaciones concretas. En este caso, por ejemplo, los emolumentos anuales ascendían a 50.000 maravedíes, a los que el sastre añadía diez ducados para gastos de hospedaje, aunque los botones y sus arreglos para la casa del conde y las personas que decidiera beneficiar debían ser costeados y pegados por el sastre. Éste, a su vez, consiguió establecer una cláusula que impedía un sobrecoste en la contratación de mano de obra, lo cual era muy probable ante la proximidad de acontecimientos festivos muy próximos; si las necesidades del taller lo requerían -"si se hiciese obra que fuese menester priesa", dice el documento-, el conde debía contratar a su costa los oficiales necesarios. AHN, Sección Nobleza, OSUNA, Caja 873, Doc. 34.

${ }^{29}$ AHN, Sección Nobleza, OSUNA, Caja.422, Doc.72, f. 3 
las delanteras, y capillas en raso anaranjado que parecen las ropas todas, en las dos fajas anchas en cada ropa, tres varas y tercia, que son veinte varas de terciopelo y de raso; llevaron en las capillas y delanteras aforradas del dicho raso anaranjado a dos varas escasas, que son lo que entró, diez varas y tres cuartas de raso y llevaron sus pestañas de tafetán" ${ }^{30}$. En cualquier caso, como podemos comprobar la inversión en vestimenta para los criados es una prueba innegable del impacto que se persigue hacer brotar entre las personas que observan la comitiva. No se trata en absoluto de hacer más operativo el viaje, como suele suceder con frecuencia, sino todo lo contrario. El conde, al igual que el resto de la comitiva de aristócratas, pretender ser visto y admirado, dotar al viaje de la pompa necesaria teniendo en cuenta el especial cometido que se le ocupa.

Cada escenario requiere, además, una puesta en escena, un atrezo especial. Los cambios de circunstancias en la corte condicionaban el gasto del conde en vestimentas para su séquito de criados y acompañantes. Acabadas las cortes de Monzón de 1533, poco antes de la salida del emperador para Ávila, Salamanca y Zamora, el séquito del conde se preparaba para el viaje en Toledo ${ }^{31}$, donde había pasado el invierno. En esta ocasión acompañaba al emperador y dado que se trataba de una gira básicamente festiva, las vestimentas del servicio vuelven a ser coloridas y vistosas. En el registro de telas y géneros usados en la confección de los trajes, Juan Note consigna una relación nueva de gastos, no sólo para los lacayos, pajes y mozos de espuela, sino también para un conjunto heterogéneo de sirvientes de todo tipo:

\footnotetext{
${ }^{30}$ AHN, Sección Nobleza, OSUNA, Caja.422, Doc.72, f. 3v

${ }^{31}$ La llegada a Toledo y el descanso de la Corte comportaba un cambio de escenario, y con ello, un cambio de la vestimenta de la servidumbre para adecuarse a las justas y fiestas de palacio que allí se dieron hasta el 22 de mayo de 1533, fecha en la que toman de nuevo el camino de Madrid en dirección a Ávila. Eso supuso el empleo de algo más de trescientas varas de terciopelo por parte de los sastres, aunque los cambios principales afectaron sobre todo a los criados más cercanos al conde.
} 


\section{Cuadro 2. Vestimentas y telas usadas con motivo de la estancia en Toledo antes de la salida hacia Salamanca (1533-1534)}

\begin{tabular}{|c|c|}
\hline Confecciones & Piezas de tela de terciopelo \\
\hline Seis jubones para los menestrales, de terciopelo anaranjado & 20 varas 1 sesma \\
\hline Seis sayos sin mangas para los menestrales & 9 varas \\
\hline $\begin{array}{l}\text { Un sayo para Lorenzo el Portero, de perpiñán, entró en la } \\
\text { guarnición de dos tiras de terciopelo blanco y verde una vara } \\
\text { y dos tercias }\end{array}$ & 1 vara 2 tercias \\
\hline $\begin{array}{l}\text { Cuatro ropas para los atabaleros con sus capillas y mangas } \\
\text { con sus fajas de terciopelo, }(\ldots) \text { y llevaban sus pestañas de } \\
\text { raso y tafetán }\end{array}$ & 9 varas \\
\hline $\begin{array}{l}\text { Cuatro jubones de terciopelo anaranjado para los cuatro } \\
\text { atabaleros... }\end{array}$ & 12 varas \\
\hline $\begin{array}{l}\text { Cuatro sayos de paño anaranjado para los dichos } \\
\text { atabaleros... }\end{array}$ & 13 varas \\
\hline $\begin{array}{l}\text { Unos cestones de terciopelo verde con sus cordones para } \\
\text { llevar de camino collación a las damas... }\end{array}$ & 7 varas 1 sesma \\
\hline Dos maletas de terciopelo anaranjado y verde & 9 varas \\
\hline $\begin{array}{l}\text { Se dieron por menudo a Leonardo, bordador, y a los otros } \\
\text { sesenta bordadores que bordaban las mangas y capillas de } \\
\text { los capotes de los cazadores y mangas de sayos de los pajes } \\
\text { y mozos de espuelas y mozos de cámara y otra gente para } \\
\text { bordar lo suso dicho... }\end{array}$ & 87 varas 2 tercias \\
\hline $\begin{array}{l}\text { Ochenta gorras para cincuenta y dos pajes y mozos de } \\
\text { cámara y } 28 \text { lacayos }\end{array}$ & 40 varas \\
\hline $\begin{array}{l}21 \text { gorras para seis menestrales y nueve trompeteros y cuatro } \\
\text { atabaleros, e Salsamón e Negredo, loco, de terciopelo verde }\end{array}$ & 10 varas \\
\hline $\begin{array}{l}7 \text { varas de terciopelo blanco y verde para guarnecer las } \\
\text { bocas de mangas de los capotes }\end{array}$ & 7 varas y 2 cuartas \\
\hline Para guarnecer en menudos & 149 varas de raso \\
\hline $\begin{array}{l}\text { Diez pendones de trompetas de damasco anaranjado para la } \\
\text { ida a Barcelona lo cual se sacó para ello de casa de Alonso } \\
\text { de Portillo... }\end{array}$ & $\begin{array}{l}30 \text { varas de damasco } \\
\text { anaranjado }\end{array}$ \\
\hline
\end{tabular}

Fuente: Vid. Cuadro I.

Las circunstancias cambiantes de la vida cortesana alrededor de Carlos V, una corte itinerante en todos los años de su reinado, muestran las constantes inversiones que deben realizarse en el vertido y la apariencia no sólo de los cortesanos, sino de los nutridos grupos de criados que les acompañan. En 1538, a la espera del embarque del 
emperador, llegados a Barcelona, puede apreciarse de nuevo la adecuación de todo el séquito del conde y cómo transformó la comitiva completamente. Se vistieron los pajes y mozos con vestidos distintos: los criados del conde cambiaron el color festivo del viaje por ropas oscuras; vestían libreas de terciopelo negro y girones de tela de oro y tiras, "a los pajes de cámara y mozos de espuela se les dieron cintas de terciopelo negro y tiras de tela de oro y manglos (sic) de terciopelo, y sus mangas bordadas de tela de oro y tela de plata, sobre terciopelo negro y a la otra gente de casa sayos de refino con tiras de terciopelo" 32 .

En total, el vestuario de la servidumbre llevó casi seiscientas varas de terciopelo, lo que podría suponer aproximadamente 22.000 maravedíes $^{33}$.

La corte suponía una intensa presencia pública, con lo que los gastos en la apariencia de las legiones de sirvientes que acompañaban en cada desplazamiento a los aristócratas era una constante en sus libros de cuentas. Cuando el conde llegó a Toledo para recibir al emperador, que venía de la jornada de cortes en Monzón (1537), para acompañarle desde la allí hasta Valladolid, donde pasaría el invierno, se gastaron miles de maravedís en las "libreas que el conde mando dar a los pajes y lacayos y otras gentes de su casa, lo cual se dio, a los pajes de cámara, sayos de terciopelo y a los lacayos, jubones flamencos anchos y calzas de terciopelo amarillo y blanco y negro..." ${ }^{34}$ Años antes, la llegada del emperador a Toledo, donde permanece todo el inverno de 1534, supuso la renovación del vestuario completo del séquito del conde, no sólo para denotar su posición junto al monarca, sino también para diferenciarse del resto de la nobleza cortesana que le rodeaba dado que, en las estancias más prolongadas, los cortesanos disponen a su alrededor toda una serie de actividades lúdicas con las que entretenerse. Una de las actividades en donde siempre intentará despuntar será en los juegos de cañas y otros divertimentos que llenaban los períodos de descanso de Carlos V.

No en vano, estos juegos eran el centro del ocio cortesano y estaban presentes en la mayoría de las grandes casas aristocráticas europeas y en las cortes provinciales. En el juego de cañas que se celebró en Nápoles con motivo de la jornada de Túnez, está descrito con profusión de detalles la vestimenta de la comitiva que acompañaba al

\footnotetext{
${ }^{32}$ AHN, Sección Nobleza, OSUNA, C.422, D.72, f. 11.

33 AGS, Sec. Estado, Leg. 1370, exp. 217 "Quenta de las seys piezas de terçiopelo que se compraron para su magestad". Manejamos precios de 1538 con fabricantes de telas genoveses. ${ }^{34}$ AHN, Sección Nobleza, OSUNA, C.422, D.72, f. 12.
} 
conde de Benavente:

"Se hicieron dieciséis marlotas con la de Hernández, de terciopelo encarnado con sus vueltas de terciopelo bordadas; tres caperuzones que se hicieron para el conde y el comendador mayor de Alcántara y para otro señor de los dichos ... [...]; se hicieron para los jugadores dieciséis caperuzones que colgaban atrás; se hicieron tres petrales de cascabeles para el conde; más se hicieron para treinta y cinco mozos de espuelas del conde y de los jugadores ... treinta y cinco gorras; ítem, se hicieron dieciséis albornoces grandes de damasco azul... más se cubrieron de tafetán azul las adargas del conde y conde de Chinchón y Nieva y todos los jugadores..." 35

En estos juegos de guerra participaban todos los nobles de la época. El uso de las telas de vivos colores, los adornos de terciopelo y los vestidos llamativos, son a la vez imagen y representación. No obstante, el gasto destinado a ellos era considerable como se desprende del gasto en telas que tuvo que desembolsar el conde de Benavente, un gasto no menor al que debía hacer en casos de enfrentamientos reales:

\section{Cuadro 3. Vestimentas del servicio del conde de Benavente en los preparativos de la campaña de Túnez}

\begin{tabular}{|l|c|}
\hline $\begin{array}{l}\text { Casacas de terciopelo morado con sus mangas largas la una } \\
\text { manga larga atrás con tiras de tela de oro y tela de plata } \\
\text { ribeteadas con raso amarillo para trece pajes que embarcaron } \\
\text { con el conde }\end{array}$ & 113 varas 3 cuartas \\
\hline $\begin{array}{l}\text { Se hicieron para catorce lacayos que fueron con el conde } \\
\text { jubones de terciopelo morado con sus tiras de tela de oro por } \\
\text { guarnición con sus ribetes de rizo amarillo }\end{array}$ & 42 varas \\
\hline Catorce capas de paño morado para los dichos lacayos & 13 varas ambos \\
\hline Para los dichos trece pajes y catorce mozos de espuelas & 7 varas \\
\hline Otro paje que tomo el conde de unas damas, por una casaca & 4 varas 2 cuarto 1 \\
\hline $\begin{array}{l}\text { Mandó dar el conde otra casaca de terciopelo a un niño de } \\
\text { Barcelona que venía allí a la posada del conde que le enviaban } \\
\text { unas señoras que llevó cuatro varas y una tercia en una gorra }\end{array}$ & $\begin{array}{l}\text { terciaras } 2 \text { cuartos } \\
\text { Se hizo para el conde un caparazón de caballo de terciopelo } \\
\text { morado que va bordado de unas hojas de tela de oro y plata }\end{array}$ \\
\hline
\end{tabular}

Ibid.

35 “Juego de cañas del conde en Nápoles, junto al emperador. Más el conde de Nieva, y el comendador mayor de Alcántara, y el marqués de Molina, y Don Juan Pimentel, y don Alonso Pimentel, y don Miguel del Barco, y don Gutierre de Avellaneda, y don Sancho del Barco, Don Juan de Beamonte, el conde de Chinchón y otros hasta quince caballeros en cuadrilla..." $A H N$, Sección Nobleza, OSUNA, C.422, D.72, f. 42. 
El documento sigue con otras piezas elaboradas para cubrir caballos y armas, y vestir al portaestandarte del conde.

En Nápoles, llegados de Túnez, vistió al servicio con terciopelo negro en las libreas, sayos con dos fajas anchas de terciopelo y pestañas de raso... Cuando entraron en Roma, se vistieron de terciopelo azul y tafetanes para las libreas (11 pajes y 12 lacayos). Se hicieron diez capas de terciopelo azul gallegas, con las capillas de encima, tan grandes y largas como la capa, con guarnicionados, tiras de tela de oro y ribeteados de raso azul (105 varas). Lo mismo para doce lacayos, capas gallegas todas ellas, llenas con unas fajas de tela de oro y con dos ribetes de raso azul y forradas todas en tafetán. (126 varas)...

\section{NOTAS FINALES}

El gasto en vestido de los nobles españoles era muy importante en sus cuentas. En parte por mantener una identidad que no se prestaba a dudas, en parte porque su estilo de vida, la cercanía y el papel político de sus casas dependía de alguna manera de mantener un aspecto acorde con su rango. Ello perdura a lo largo del tiempo y es común a todas las grandes casas aristocráticas castellanas. A la muerte de la duquesa viuda de Béjar, María Alberta de Castro, décima duquesa, su hijo Juan Manuel López de Zúñiga saldó 6.000 reales de gasto en telas que la duquesa había adquirido en Madrid con Pablo Rodríguez Mate, mercader de la Calle Mayor de Madrid, al que aún se le debían 1.281 reales por compras realizadas poco tiempo atrás $(1706)^{36}$. La deuda a la que tuvo que hacer frente el duque para pagar a la servidumbre a la que se le debía parte de su sueldo ascendía a 50 ducados para la criada de las damas, en concepto de legado, más 69 reales que se le debían del sueldo del mes de julio en que murió la duquesa; a los tres mozos de silla, por dos meses de servicio y el coste de dos libreas, 930 reales; a Blas Canero, lacayo, tres reales de sueldo y ocho para la casa; al maestro de coches, cuyos servicios incluían tanto el mantenimiento como el resguardo de los coches, se le liquidaron 1.400 reales por siete meses de servicio; al sastre de la casa se le pagaron 1.757 reales y medio. Al cocinero se le adeudaban 11.915 reales, a su ayudante, 62 y 38 al mozo de despensa; al maestro cabestrero, 47; al guarnicionero, 66; al zapatero, 24; al caballerizo se le adeudaban 187 reales; 248 a Don José Chacón, gentilhombre de la duquesa y finalmente, 13.200 a Inés Negrete, su dama, a la que había legado en su testamento la cantidad de 1.200 ducados. Las deudas contraídas con un repostero, un cordonero y un platero ascendían a más de 1.000 reales. Sólo en la

${ }^{36}$ AHN, Sec. Nobleza, Osuna, C.257. D. 43 
servidumbre de su madre difunta, la deuda del duque ascendía a algo más de 36.000 reales ${ }^{37}$.

${ }^{37}$ Poco tiempo después (13 de marzo de 1709) moría la segunda esposa del duque, Manuela de Toledo Osorio y Aragón, constan sólo 23 años de edad. Gastó 8.151 reales en misas el día de su funeral. Doña Rafaela, tercera esposa del duque de Béjar, dejó encargadas misas por valor de 12.060 reales. El gasto en la dignificación de la casa, como vemos, no acababa con la vida de sus protagonistas. 


\title{
EL PAN Y EL ORO. CONSUMO DIFERENCIADO EN LA CIUDAD DE CUENCA DURANTE LA GUERRA DE SUCESIÓN ESPAÑOLA ${ }^{1}$
}

\section{BREAD AND GOLD. DIFFERENTIAL HUMAN CONSUMPTION IN THE CITY OF CUENCA DURING THE WAR OF SPANISH SUCCESSION}

\author{
VÍCTOR ALBERTO GARCÍA HERAS \\ Facultad de Humanidades de Albacete - Universidad de Castilla-La \\ Mancha \\ VictorAlberto.Garcia@uclm.es
}

Recibido: $12 / 09 / 2016$

Aceptado: 10/12/2016

RESUMEN: El presente artículo tiene por objetivo poner de manifiesto las prácticas de consumo en el interior de Castilla durante un periodo bélico y convulso como la guerra de Sucesión. Para llevarlo a cabo hemos trabajado la diversa documentación municipal contenida en el Archivo Histórico Municipal de Cuenca, los protocolos notariales depositados en el Archivo Histórico Provincial de Cuenca y documentación proveniente del Archivo Histórico Nacional. El trabajo con toda la documentación ha consistido en la descarga y comparación sistemática de las informaciones referentes a prácticas de consumo, abastecimiento de la población, precios, carestías, etc., y por lo que respecta a la documentación notarial se han trabajado los testamentos e inventarios de bienes que podían aportar información sobre las prácticas de consumo de las élites. Hemos podido constatar que la falta de abastecimiento de algunos productos, sobre todo del trigo, supone un importante factor de inestabilidad y descontento social. De la misma forma y de manera paralela, las élites locales llevaban a cabo prácticas de consumo que las diferenciaba tanto económica como simbólicamente del resto de la población.

PALABRAS CLAVE: Guerra de Sucesión, élites, consumo, lujo, Cuenca, abastecimiento.

ABSTRACT: The objective of this article is to reveal the practices of human consumption in the interior of Castile during a war and convulsive period as the War of Spanish Succession. In order to carry it out, we have worked on various local documents

\footnotetext{
${ }^{1}$ El presente artículo forma parte del proyecto de investigación: "Familia, desigualdad social y cambio generacional en la España centro-meridional, 1700-1900" referencia HAR201348901-C6-6-R, del que es Investigador Principal D. Francisco García González y ha sido posible gracias a la financiación concedida por el Ministerio de Economía y Competitividad.
} 
from the Archivo Municipal de Cuenca, Notary Public Documents filed in the Archivo Histórico Provincial de Cuenca and documentation from the Archivo Histórico Nacional. All this documentation has allowed a systematic download and comparison of information related to practices of human consumption, population supply, prices, shortages, etc. Regarding Notary Public Documentation, we have worked on wills and goods stocks to obtain information on human consumption practices of elites. We have been able to confirm that lack of supply of some products, especially wheat, was an important factor of instability and social unrest. In the same way and in parallel, local elites carried out human consumption practices well differentiated economically and symbolically from the rest of the population.

KEYWORDS: War of the Spanish Succession, elites, consumption, luxury, Cuenca.

\section{INTRODUCCIÓN}

El artículo tiene por objetivo poner de manifiesto las prácticas de consumo durante un periodo bélico y convulso como la guerra de Sucesión. Durante una guerra la población se ve obligada a convivir con la escasez y carestía de los productos básicos que suponen la base sobre la que se asienta en gran medida su supervivencia. La falta de abastecimiento de algunos de estos productos, sobre todo de la carne y del trigo, supone para las autoridades concejiles un importante escollo que solventar para impedir posibles revueltas y protestas por parte del común. Un momento de tanta intensidad política y bélica se traduce históricamente en un espacio en el que poder analizar los distintos comportamientos adoptados por el conjunto de la población ante la escasez de bienes de primera necesidad y los llevados a cabo por las élites, lo que nos puede mostrar el grado de conflictividad social alcanzado en un territorio tradicionalmente definido como fiel al primer representante de la dinastía Borbón en España.

La variedad de los productos que llegaban a una ciudad del interior de Castilla durante un periodo caracterizado por la inestabilidad bélica constituye un indicador para poner de relieve cómo sus habitantes se vieron obligados a modificar sus prácticas de consumo durante el conflicto debido al encarecimiento de los productos básicos para la subsistencia, como el trigo. Otro de los colectivos que se vio directamente afectado por la falta de suministro de alimento fueron los soldados y con ellos la defensa de las posiciones alcanzadas por los candidatos al trono. Los ejércitos contendientes necesitados de pertrechos se convierten durante la guerra en unos demandantes incesantes de productos que nutriesen sus almacenes y conllevaron los consiguientes problemas para garantizar el abastecimiento de las tropas a las instituciones locales que habrían de alojarlos en sus villas y ciudades. Durante el 
Antiguo Régimen el aprovisionamiento de armas, pero también el avituallamiento, resultaba esencial para mantener las posiciones militares; qué consumían y quién se encargaba de suministrar estos pertrechos a los ejércitos que conformaban las guarniciones de defensa de las distintas localidades durante la guerra de Sucesión, nos mostrará la relevancia que llegaba a alcanzar el abastecimiento de las tropas en los momentos de escasez.

De la misma forma y de manera paralela, las élites locales llevaban a cabo prácticas de consumo que las diferenciaba tanto económica como simbólicamente del resto de la sociedad, viéndose apartadas, en gran medida, de las dificultades que afectaron a la mayoría de la población durante la guerra de Sucesión. El mantenimiento del estatus privilegiado en unos casos y el logro, en otros, de esta posición se va a ver plasmado en unas prácticas de consumo caracterizadas por el lujo. El consumo de obras de arte, joyas, objetos de plata y oro, vestidos, etc., se convertirá en una muestra de diferenciación social que ponga de manifiesto la posición social alcanzada dentro de las sociedades del Antiguo Régimen, pese a las críticas que el consumo de productos de lujo provocaba en algunos tratadistas.

\section{EL CONSUMO DEL COMÚN, SUBSISTIR EN TIEMPOS DE GUERRA.}

Los más importantes autores sobre el régimen municipal se han referido ampliamente al tema de los mantenimientos. En el caso del más arquetípico, como es Castillo de Bobadilla, indica que cada uno de los productos se debería vender en partes señaladas de la ciudad y distintas entre ellas. Esta exigencia obedecía a un deseo de orden y policía en la ciudad y para que la Justicia tuviera más fácil la visita del mercado ${ }^{2}$. El abastecimiento y el mercado urbano llenan de por sí un buen tanto por ciento de la actuación municipal ${ }^{3}$, de ahí su relevancia a la hora de analizar el consumo de Cuenca durante estos años.

El abastecimiento de la ciudad, al estar encomendado al Concejo, se veía mediatizado por una falta de racionalización en la comercialización de los productos,

\footnotetext{
${ }^{2}$ F.J. ARANDA PÉREZ y M. GARCÍA RUIPÉREZ (1999). "Posturas y penas en el mercado. Los fieles ejecutores en Castilla en la Edad Moderna”. En de Bernardo Ares, J. M. y González Beltrán, J. M. (eds.), La Administración Municipal en la Edad Moderna. Cádiz, Universidad de Cádiz, p. 351.

${ }^{3}$ F.J. GUILLAMÓN ÁLVAREZ (1988-1990). “Algunos presupuestos metodológicos para el estudio de la administración: el régimen municipal en el siglo XVIII”. Revista de Historia Moderna, Anales de la Universidad de Alicante, nº. 8-9, p. 61.
} 
por los obstáculos consecuencia de cualquier eventualidad climática que provocase malas cosechas y por las deficiencias innatas en el propio régimen de administración de los bienes municipales ${ }^{4}$. La política de abastos sobreponía el interés social al particular y suponía una verdadera preocupación para las autoridades locales ${ }^{5}$, como tendremos lugar de poner de manifiesto, principalmente en lo que respecta a los productos fundamentales como el pan. Para lograr garantizar la calidad y, sobre todo, la cantidad de los abastos, la ciudad nombraba dos comisarios entre sus regidores que se habrían de encargar de supervisar que las medidas eran las correctas, que no se producía fraude y, en el caso del trigo, garantizar la compra de una cantidad suficiente para el abasto de las panaderas. De hecho, el carácter garantista había hecho que se desarrollase el sistema de obligados de abastos en muchas localidades a lo largo de la Edad Moderna, provocando la intervención de los precios de los productos de primera necesidad ${ }^{6}$. Aun con esta garantía, los precios no pararán de subir de forma general durante el periodo estudiado en toda la región, pasando de un índice de 58 en 1690, a 65,8 en 1700 y 73,5 para 1710, mientras que los salarios verán una evolución inversa ${ }^{7}$, lo que conlleva un aumento en las dificultades de abastecimiento de la población de la ciudad por la consiguiente pérdida de poder adquisitivo.

En estos primeros años del siglo XVIII el abasto parece resultar bastante rentable al igual que en otras ciudades como Madrid, donde un grupo familiar como los Prieto Haedo se hace con el control de los abastos como fuente de pingües beneficios ${ }^{8}$. Aunque no podemos valorar las ganancias finales que cada uno de los arrendadores

${ }^{4}$ J.Ma. GARCÍA MARÍN (1985). "La reconstrucción de la administración territorial y local en la España del siglo XVIII". En La época de los primeros borbones. La nueva Monarquía y su posición en Europa (1700-1759). Madrid: Espasa-Calpe, p. 215.

${ }^{5}$ C.M . CREMADES GRIÑÁN (1984). Alimentación y consumo en la ciudad de Murcia durante el siglo XVIII (1701-1766). Murcia, Universidad de Murcia, p. 42.

6 A. MARCOS MARTÍN (1996). "Historia y desarrollo: el mito historiográfico de la burguesía”. En Enciso Recio, L.M. (coord.). La Burguesía Española en la Edad Moderna, I. Valladolid: Universidad de Valladolid-Fundación Duques de Soria-V Centenario Tratado de Tordesillas, p. 24.

7 M.R. PARDO PARDO (2000). "Base socioeconómica de los siglos XVI y XVII" y "Transformaciones económicas bajo el signo del reformismo borbónico". En Pardo Pardo, M.R. (coord.). Historia Económica de Castilla-La Mancha (siglos XVI-XX). Madrid: Celeste Ediciones, pp. 30 y 38.

8 F. ANDÚJAR CASTILLO (2015). "Negocios privados, cargos públicos: el recurso a testaferros en la etapa del cambio dinástico". En Solbes, S y Dubet, A. (coords.). "Actores políticos y actores privados en el gobierno de la Hacienda”. Revista Tiempos Modernos, vol. 8, $\mathrm{n}^{\mathrm{o}} 30$. 
obtenía en un año en el que el abasto no sufriese ningún contratiempo extraordinario, la repetición como arrendatarios de Alonso Carrascosa, Miguel Sanz o Gabriel Rodríguez, durante este periodo, es suficiente dato para explicar los beneficios logrados, ya que cuando se ponen en duda, nadie puja por el contrato9.

\subsection{El pan: garantizar el consumo a toda costa.}

Braudel ya aludió tiempo atrás a la trilogía que, en su opinión, conducía la historia de Europa: trigo, harina y pan. De ahí que mientras una buena cosecha representaba, sin ningún género de dudas, una bendición del cielo, la simple sospecha de ausencia de trigo en el año generaba la alerta de los consumidores ${ }^{10}$. Los concejos, conscientes de la importancia estratégica que había alcanzado el pan, observaban con atención constante el nivel de las cosechas, la oscilación de los precios, la marcha del comercio de cereales, llegando en momentos de crisis a intervenir el mercado, subvencionando las importaciones para atraer cereal a la ciudad, creando reservas, que sirvieran de seguridad y regulación, y tasando los precios ${ }^{11}$.

El mercado de cereales estaba bajo el marco del intervencionismo mercantilista de la época. Ante el peligro de agitaciones populares y motines de subsistencias, las administraciones intervienen en la distribución de productos alimenticios, especialmente el grano, distorsionando con ello los mercados ${ }^{12}$. El impacto de las crisis de subsistencia durante la época moderna causadas por fenómenos naturales, en su gran mayoría, con sus derivaciones sobre los precios, la mortalidad o la nupcialidad, intentaron ser atenuadas por las intervenciones de la administración municipal, ya fuese con la importación de trigo, el control de los precios o la gestión de los pósitos ${ }^{13}$;

\footnotetext{
${ }^{9}$ GÓMEZ ZORRAQUINO citado en J.A. ARMILLAS VICENTE y P. SANZ CAMAÑES (1996). "El municipio aragonés en la Edad Moderna: Zaragoza, caput regni". En De Bernardo Ares, J.M. y Martínez Ruiz, E. (eds.). El municipio en la España Moderna. Córdoba: Universidad de Córdoba, p. 63.

${ }^{10}$ A. ALBEROLA ROMÁ (1999). "Abasto urbano y protesta popular en tierras valencianas durante el siglo XVIII”. En De Bernardo Ares, J.M. y González Beltrán, J.M. (eds.). La Administración Municipal en la Edad Moderna. Cádiz: Universidad de Cádiz, p. 322.

${ }^{11}$ MaA. PÉREZ SAMPER (1999). "El pan en la Barcelona moderna: Poder municipal y abastecimiento". En De Bernardo Ares, J. M. y González Beltrán, J. M. (eds.). La Administración Municipal en la Edad Moderna. Cádiz: Universidad de Cádiz, p. 409.

${ }^{12}$ C. DE CASTRO (1987). El pan de Madrid. El abasto de las ciudades españolas del Antiguo Régimen. Madrid: Alianza Universidad, p. 58

13 J. DANTÍ I RIU (2012). "La diversidad agraria en la España moderna: Campo, campesinos y actividades productivas". En Pérez Álvarez, Mª. J. y Rubio Pérez, L. M. (eds.). Campo y
} 
en el caso de Cuenca, se debería valer de las dos primeras al carecer de pósito durante la guerra de Sucesión.

El pan era el alimento básico de todos, muy especialmente de los grupos populares. El pan de trigo estaba reservado a las gentes más acomodadas. El pan común de las clases populares y del campesinado estaba hecho de otros cereales como la cebada, en muchos casos, mezclada con trigo ${ }^{14}$. A finales de la década de los años 90 del siglo XVII, la situación es dantesca en cuanto al abastecimiento de trigo en Cuenca se refiere, y el regidor y comisario encargado de su abasto, D. Juan Cerdán, informa de que si en un año normal se consumen en Cuenca unas 12000 fanegas de trigo, en noviembre de 1699 no ha conseguido nada más que $4000^{15}$.

Los precios agrícolas eran aún buenos en 1706, pero no tan bajos como en 1703 y 1704, pagándose el pan a 20 maravedíes en Madrid y a 20 reales las fanegas de trigo y de cebada. En Andalucía el precio había subido de 17 a 18 maravedíes por ración de pan en 1704 y la fanega de cebada de 15 a 19 reales. En Castilla y Extremadura el precio del pan alcanzaría los 22 maravedíes, algo más caro de lo que hemos consignado para Cuenca por estas fechas, y la cebada a $19^{16}$.

En agosto de 1706, los ejércitos de ambos bandos están necesitados de pan, por lo que Felipe V le escribe al marqués de Valdeguerrero, como gobernador del Real Sitio de Aranjuez, para que ponga a disposición del director de víveres de las tropas francesas los molinos que le sobren para moler el trigo que necesitan las tropas; se le contesta que es imposible, puesto que no hay suficientes para el abasto de la gente de La Mancha ${ }^{17}$. A mediados del mes de octubre de 1706 el limosnero de la catedral de Cuenca se queja de que se debía haber abierto la limosna para los pobres de la ciudad y que no se había hecho, para que los soldados austracistas no tuviesen noticia del trigo y lo sacasen con violencia. Se queja también de que en 1705 habían quedado tan solo

campesinos en la España Moderna. Culturas politicas en el mundo hispánico, I. León: Fundación Española de Historia Moderna, p. 218.

${ }^{14} \mathrm{M}^{\mathrm{a}} \mathrm{A}$. PÉREZ SAMPER (2012). "La alimentación catalana en la Edad Moderna, según el Libre dels secrets d'agricultura, casa rústica i pastoril de Miquel Agustí”. En Pérez Álvarez, $\mathrm{M}^{\mathrm{a}}$. J. y Rubio Pérez, L. M. (eds.). Campo y campesinos en la España Moderna. Culturas políticas en el mundo hispánico, II, León: Fundación Española de Historia Moderna, p. 1487.

${ }^{15}$ Archivo Histórico Municipal de Cuenca (en adelante A.H.M.C.) Leg. 304. Acta Municipal 28-11-1699.

${ }^{16}$ C. DE CASTRO (2004). A la sombra de Felipe V. José de Grimaldo, ministro responsable (1703-1726). Madrid: Marcial Pons, p. 179.

${ }^{17}$ Archivo Histórico Nacional (en adelante A.H.N.) Sección Estado, Leg. 301. 
150 almudes de trigo, cuando otros años habían quedado $800^{18}$.

En 1707 el corregidor informó a la ciudad de que, tras la muerte del obispo D. Alonso Antonio de San Martín, había localizado varias partidas de trigo en las cercanías de Huete en manos de los terceros de los años anteriores. Estas partidas sumaban 2100 fanegas y podía traerlas para el abasto de la ciudad pagando tan solo el precio del transporte y su coste conforme se fuesen deshaciendo y vendiendo en las panaderías. Añade, además, que de las 800 que había ajustado en El Provencio tan solo habían llegado 160 porque las justicias locales impedían que se sacase el trigo de la población, alegando que lo necesitaban para abastecer a las tropas que se encontraban acampadas allí. Ante este contratiempo, D. Juan Cerdán de Landa expuso que él tenía un despacho que le autorizaba a que todos los granos que necesitase la ciudad para la manutención de la guarnición que el duque de Berwick había dejado en Cuenca para su defensa, tras reconquistarla, los conduzca de las partes que lo necesitare sin que con ningún pretexto se embarace su saca ${ }^{19}$. En las decisiones de las autoridades concejiles primaba el aprovisionamiento a sus vecinos al menor precio posible, y en años de carestía tienden a prohibir, contra la ley del reino, la venta a compradores forasteros y la extracción ${ }^{20}$ para evitar los conatos de revuelta que se pudieran producir ante la falta de abastecimiento.

La pobre cosecha de 1707 deparó una aún más escasa al año siguiente, el cual parece ser que fue de sequía y escasos rendimientos en todo el sur de Francia y el resto del continente europeo, propiciando que 1708 fuera uno de los «más fatales» padecidos, al decir de Zabala y Auñón. Para Gonzalo Anes, la gran crisis agraria de este año acrecentaría los efectos negativos de la guerra, provocando notables pérdidas demográficas, incrementando la miseria de los campesinos y la regresión de los cultivos $^{21}$. En agosto de 1708 el corregidor pide ayuda al Cabildo para el abasto de la ciudad por lo corto de la cosecha de este año ${ }^{22}$. La situación se complica y el corregidor informa de que ha llevado a cabo trámites con el Cabildo para intentar garantizar el abasto por la epidemia general que se padecía y que para ello estaba dispuesto a

\footnotetext{
${ }^{18}$ Archivo Catedral de Cuenca (en adelante A.C.C.) Sección Secretaría. Serie Actas. Libro 179. Acta Capitular 20-10-1706.

${ }^{19}$ A.H.M.C. Leg. 312. Acta Municipal 26-1-1707.

${ }^{20}$ C. DE CASTRO (1987). El pan de Madrid. El abasto..., op. cit., p. 63.

${ }^{21}$ A. ALBEROLA ROMÁ (2004). "Oscilaciones climáticas y coyuntura agrícola en tierras valencianas durante el reinado de Felipe V". En Serrano, E. (ed.). Felipe V y su tiempo, I. Zaragoza: Institución Fernando el Católico, p. 210.

${ }^{22}$ A.C.C. Sección Secretaría. Serie Actas. Libro 180. Acta Capitular 21-8- y 19-9-1708.
} 
vender y a empeñar todas sus alhajas ${ }^{23}$. Con estos antecedentes se llega al año 1709 que comienza con una profunda escasez de trigo debida en gran medida a la especial dureza del invierno, en el que por la conjunción de diversas causas climáticas se produjo el peor invierno del periodo. En Francia el invierno hizo estragos abocando, según Vauban, al 10\% de la población francesa a vivir de la limosna y el resto, con gran estrechez ${ }^{24}$.

En febrero de 1709 varios prebendados de la catedral habían dado libramientos para sacar trigo de las tercias de La Mancha, pero las justicias locales lo habían impedido para garantizarse el propio abasto, por lo que la ciudad tuvo que buscar trigo para su abastecimiento en poblaciones mucho más lejanas, enviando a D. Juan Cerdán de Landa, como comisario, hasta Molina de Aragón ${ }^{25}$ en busca de trigo con el que poder satisfacer el consumo de Cuenca. Las acciones llevadas a cabo por D. Juan Cerdán de Landa para garantizar el abasto, pese a su imposible desempeño por la general carencia de frutos que padece todo este obispado, van a ser numerosas y de distinta índole: la entrega a las panaderas de la ciudad de 160 fanegas de su propio trigo; la consecución de que los canónigos del Cabildo entregasen libranzas por valor de otras 2000 fanegas al depositario del abasto nombrado por la ciudad, Miguel Sanz Paniagua y conseguir que el obispo, D. Miguel del Olmo, ofreciese entregar otras 4000 fanegas a cambio de que el propio D. Juan Cerdán las avalase con sus propias alhajas, si bien el obispo no consintió admitirle las fianzas y puso a disposición de la ciudad el trigo, con la condición de que se le pagase de lo obtenido por la venta del pan. No conforme con todas estas, en pleno mes de enero D. Juan Cerdán había partido a través de la Serranía de Cuenca camino de Sigüenza y de Molina de Aragón, todavía convaleciente de una enfermedad, para intentar conseguir surtirse de una cantidad mayor de trigo. Después de muchas diligencias, consiguió negociar y apalabrar otras 1200 fanegas, para cuyo traslado su hermano, D. Julián Cerdán de Landa, pidió al Concejo que se hiciera cargo del coste, con el objetivo de que puedan servir al socorro de su pueblo, ofreciéndose él mismo a pagar el coste del transporte en el caso de que la ciudad no contase con el dinero líquido en esos momentos ${ }^{26}$.

A principios de marzo, los dos comisarios, D. Juan Cerdán y D. Francisco Castillo,

\footnotetext{
${ }^{23}$ A.H.M.C. Leg. 313. Acta Municipal 22-9-1708. p. 29.

${ }^{25}$ A.H.M.C. Leg. 314. Acta Municipal 5-2-1709.

${ }^{26}$ A.H.M.C. Leg. 314. Acta Municipal 8-2-1709.
}

${ }^{24}$ A. DOMÍNGUEZ ORTIZ (1984). Sociedad y Estado en el s. XVIII español. Barcelona: Ariel, 
consiguieron apalabrar una gran suma de trigo, entre 6000 y 7000 fanegas en Sigüenza, y pidieron a la ciudad que juntase el dinero de su importe a la mayor brevedad posible, ya que por lo que habian experimentado, convenía su ejecución pronta porque cada día se alteraba el precio en aquella tierra respecto de la común falta de trigo ${ }^{27}$.

Las necesidades de granos afectan también a los ejércitos reales y con ello a la capacidad operativa de los soldados y al desarrollo de la guerra. Así, D. Luis Antonio de Mergelina y Mota, como encargado del abastecimiento de las tropas, escribe a D. José Grimaldo informándole de que se encuentra realizando todas las diligencias necesarias para las compras de cebada, aunque no se logra el aumento que desea a causa de lo exhaustos que están los pueblos de granos, por lo que da la orden para embargar todos los bagajes necesarios para la conducción de cebada a Extremadura, a la ciudad de Mérida, cuyo transporte se habrá de pagar a 11 maravedíes/legua/fanega; en cuanto al trigo, ha enviado a algunas villas peticiones para que envíen fanegas de trigo, como a Alcázar o Argamasilla (de Alba) del priorato de San Juan ${ }^{28}$.

Los pueblos de La Mancha no tienen grano para su abasto y, por tanto, tampoco para vender para el abastecimiento de Cuenca. La situación de escasez y la subida del precio del trigo por parte del Concejo conllevará el desencadenamiento de un tumulto en las calles de Cuenca en marzo de $1709^{29}$ contra las autoridades borbónicas, que se verá rápidamente sofocado por la intervención del corregidor y de la justicia contra los cabecillas y por la inmediata rectificación en la medida que había supuesto el detonante de la revuelta. A principios de abril, el regidor D. Francisco Castillo vuelve a insistir para que se suba el precio del pan por las crecidas pérdidas, alrededor de 6000 o 7000 reales hasta la fecha, que se le venían ocasionando a la ciudad, al haber mantenido el precio a 6 cuartos debido al motín que se produjo el 18 de marzo. La ciudad, en cumplimiento de las indicaciones del Consejo de Castilla, acordó subir el precio a 7 cuartos para los vecinos y a 8 cuartos para los forasteros sin que se pregonase la subida para evitar más alteraciones ${ }^{30}$. El precio del trigo no para de subir y D. Juan Cerdán ajusta otras 250 fanegas en Sigüenza a 33 reales y la ciudad se ve obligada a aprobar la compra, pese al precio tan alto al que se ha ajustado ${ }^{31}$. Otro ejemplo de la subida del precio del trigo lo encontramos en Jaén donde durante 1708 se encareció un 47\%,

\footnotetext{
${ }^{27}$ A.H.M.C. Leg. 314. Acta Municipal 1-3-1709.

${ }^{28}$ A.H.N. Sección Estado, Leg. 492.

${ }^{29}$ A.H.M.C. Leg. 314. Acta Municipal 18-3-1709.

${ }^{30}$ A.H.M.C. Leg. 314. Acta Municipal 3-4-1709.

${ }^{31}$ A.H.M.C. Leg. 314. Acta Municipal 16-4-1709.
} 
pasando de 19 reales por fanega a principios de año hasta los 28 reales de octubre ${ }^{32}$.

Figura 1. Evolución de los precios de la fanega de trigo y del pan de dos libras en Cuenca 1692-1714

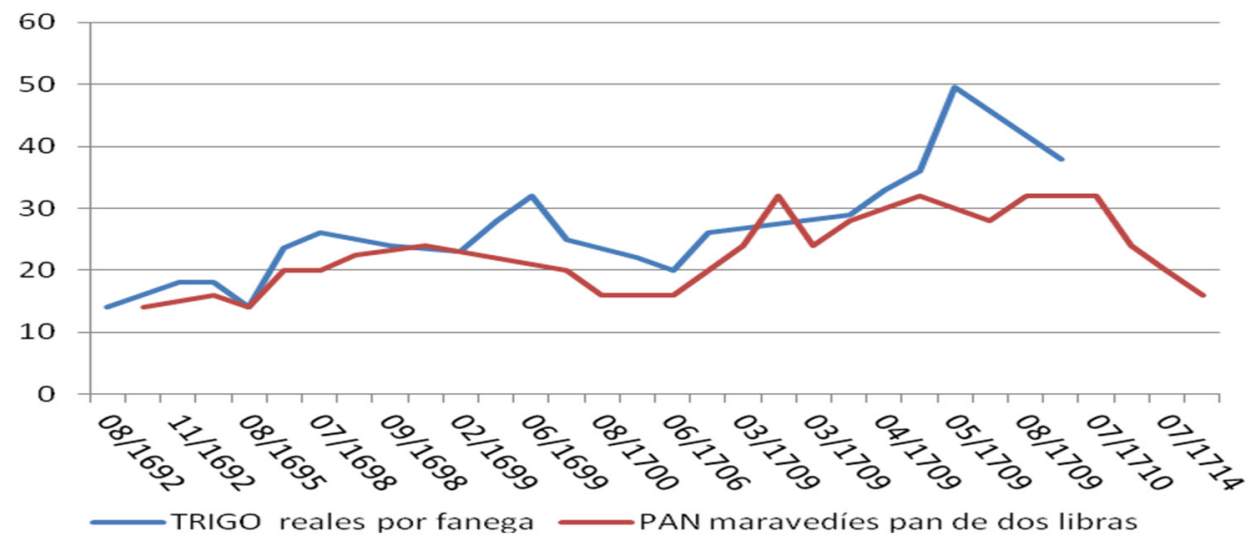

Fuente: A.H.M.C. Legs. 297-317. Actas Municipales 1692-1714.

Tal y como se muestra en la figura 1, a partir de 1709 el precio del trigo comienza a bajar pese a lo cual, en 1713 D. Juan José Miera Castañeda, recién tomada la posesión del cargo de corregidor y viendo la falta de pan en la que se hallaba la ciudad, pidió a los regidores que le informasen de quién podía tener trigo para garantizar el abasto y la ciudad mandó llamar de nuevo a D. Juan Cerdán de Landa para que proporcionase el que pudiera. La confianza depositada por el Concejo en D. Juan Cerdán para conseguir trigo suficiente en los momentos más duros de la crisis de subsistencia y el encargo recibido para garantizar el abastecimiento de la guarnición que había quedado en Cuenca por orden del duque de Berwick, nos indican la actividad económica que desarrolla D. Juan durante estos años, convirtiéndose en un miembro de la élite política y económica de la ciudad, posición que también se verá reflejada en las prácticas de consumo diferenciado de su familia. La escasez provoca que de las 1000 fanegas que el obispo había concedido en Huete tan solo se pudieron llevar a Cuenca 250, puesto que las autoridades locales dificultaban la saca de trigo para poder garantizar el abasto de su propia población. Ante esta situación y la escasez de trigo que de forma recurrente se sufre en la ciudad, el corregidor propuso que a los vecinos de mayor

${ }^{32}$ H. RODRÍGUEZ DE GRACIA (2001). "La Guerra de Sucesión. El crecimiento de los impuestos y sus consecuencias en Jaén". En La Guerra de Sucesión en España y América, X Jornadas Nacionales de Historia Militar. Madrid: Deimos, p. 748. 
caudal se les precisase a que tuviesen siempre en sus casas una cantidad de trigo para prestar a la ciudad y que así quedase garantizado el abasto. Los regidores aprobaron la propuesta y acordaron tener 500 fanegas que pusieron a disposición del corregidor y sugirieron que los vecinos que tuvieran el trigo prevenido lo pudiesen cocer en sus casas y lo vendieran al precio que estuviese puesto en cada momento, sin intervención de las panaderas ${ }^{33}$. Parece que los miembros del Concejo no se encuentran afectados directamente por la crisis de subsistencia que afecta al resto de la población al contar con trigo suficiente para garantizar su propio consumo y, ahora también, contribuir con el de la ciudad. La situación de crisis y la falta de trigo para garantizar el abastecimiento de la ciudad obligan a las autoridades reales a encomendar la búsqueda de soluciones a miembros de la élite local. Por fin, en 1714 el corregidor puede decir que siendo la cosecha muy abundante como parecía y estando tan inmediata, tenía por conveniente se bajase el pan y moderase al mismo tiempo la cebada que se vende en los mesones ${ }^{34}$.

Los productos con los que se abastecía la ciudad constituyen una muestra para conseguir observar las prácticas de consumo de la población durante un periodo tan convulso como la guerra. A través de las dificultades, o por el contrario abundancia, de los distintos abastecimientos podemos observar las distintas prácticas fraudulentas (acaparamiento, rebaja en la calidad del producto, etc.) que se producían entre los vendedores. Algunas de estas prácticas intentaban ser solventadas por el Concejo, pero otras eran flagrantemente toleradas pese a las quejas que se presentaban por los síndicos del común, constituyendo una dificultad añadida a las ya acuciantes dificultades para abastecerse que padecían las gentes del común.

\section{CONSUMIR LUJO, DIFERENCIARSE SOCIALMENTE.}

Senac de Meilhan escribía en 1797 que [el fasto] anuncia la superioridad del rango; se manifiesta por la pompa, el esplendor, la decoración (...). El lujo es más un atributo particular de los ricos ${ }^{35} \mathrm{y}$ pese a las múltiples normas contra las prácticas suntuarias y

\footnotetext{
${ }^{33}$ A.H.M.C. Leg. 316. Acta Municipal 29-4, 20-6, 8-7-1713.

${ }^{34}$ A.H.M.C. Leg. 317. Acta Municipal 21-7-1714.

${ }^{35}$ G. SENAC DE MEILHAN (1787). Considérations sur les richesses et le luxe. Amsterdam y París, p. 88 citado en M. FIGEAC (2015). "La vida material de la nobleza francesa, entre el 'Gran Siglo' y el Siglo de las Luces: una lectura de las diferenciaciones sociales en el seno del estamento nobiliario". Revista Investigaciones Históricas: Época moderna y contemporánea, p. 67.
} 
de ostentación recogidas en el siglo XVIII por autores como Sempere Guarinos ${ }^{36} \mathrm{o}$ Manuel Romero ${ }^{37}$, que instruían sobre los efectos perniciosos del lujo, las élites practicaban unos hábitos de consumo que denotaba una diferenciación social a través de los bienes que se compraban y se poseían, mientras la población de Cuenca sufría los menoscabos propios de la guerra y de la escasez, cuyo descontento se mostró en el tumulto que tuvo lugar en 1709. Como obispo de Badajoz durante la guerra de Sucesión y después de la guerra como arzobispo de Toledo, D. Francisco Valero y Losa se caracterizará por unas prácticas y prédicas contra el lujo por considerarlo no solo ocasión de infinitos pecados, sino que empobrece las casas de las familias. Entre las razones esgrimidas se mezclaban las de naturaleza política, pues los políticos consideran al lujo útil al Estado teniendo en consideración el aumento del comercio activo y pasivo, y las de naturaleza moral argumentando que ningún filósofo cristiano nunca podrá sostener que el lujo se pueda reputar por inocente ${ }^{38}$. Las indicaciones del obispo Valero no surtieron los efectos esperados entre las élites conquenses y ni tan siquiera entre los miembros de su propia familia, los Cerdán de Landa, quienes se destacarán por un consumo diferenciado que los caracterizará como uno de los linajes más notables de la ciudad durante la guerra de Sucesión. Entre los bienes de lujo serán de especial significación las joyas y los productos exóticos, como la porcelana china o los muebles de caoba o ébano, como se mostrará en el caso de la familia Cerdán o en el de los condes de Siruela. El consumo de productos de lujo supone un "consumo ostensible" que distingue a los individuos entre sí y fortalece sus pretensiones de estatus $^{39}$. Estas prácticas de consumo entroncaban dentro de una movilidad socioideológica y cultural (que se retroalimentaba de las críticas suscitadas en torno a la "apariencia") que se plasmaba en la demostración pública y la privada a través de consumos aparentes ${ }^{40}$.

\footnotetext{
${ }^{36}$ J. RICO GIMÉNEZ (2000). "Estudio preliminar”. De Sempere y Guarinos, Historia del lujo $y$ de las leyes suntuarias de España. Valencia: Institució Alfons el Magnànim, pp. 9-66.

37 E. MARTÍNEZ CHACÓN (1985). "Estudio preliminar". De Efectos perniciosos del lujo: Las cartas de D. Manuel Romero del Álamo al Memorial Literario de Madrid (1789). Oviedo: Universidad de Oviedo, pp. 9-48.

${ }^{38}$ J. IGLESIAS GÓMEZ (1998). Vida de Don Francisco Valero y Losa (1664-1720) Arzobispo de Toledo. Madrid: La Librería, p. 71.

${ }^{39}$ J. DE VRIES (2009). La revolución industriosa. Consumo y economía doméstica desde 1650 hasta el presente. Barcelona: Crítica, pp. 35 y 36.

${ }^{40}$ M. GARCÍA FERNÁNDEZ (2013). "Prefacio. Cultura e identidades: nuevos horizontes y planteamientos de futuro". En García Fernández, M. (coord.). Cultura material y vida cotidiana moderna: escenarios. Madrid: Sílex, p. 10.
} 
Más allá de las distintas casas, rentas, oficios, heredades o ganado que poseían los miembros de la élite conquense y que constituían su fuente fundamental de riqueza, nos centraremos en aquellos objetos especialmente valiosos, por su precio, material en el que estaban hechos o por su exotismo, al provenir de mercados más o menos lejanos (porcelanas chinas, alfombras turcas, etc.), y que representaban para quien los poseía un elemento de diferenciación social al poder poseer objetos reservados tan solo a un grupo muy reducido de individuos. En 1706 fallece doña Esperanza Valero, esposa de D. Juan Cerdán y hermana de D. Francisco Valero y Losa, quien alcanzó la mitra de Badajoz y el arzobispado de Toledo por los servicios prestados a Felipe V durante la guerra de Sucesión, por lo que nos encontramos ante una de las familias proborbónicas más relevantes de la ciudad de Cuenca. En su testamento podemos apreciar los objetos más valiosos que poseían los miembros de las élites. Dña. Esperanza donó el vestido rojo con guarnición con el que se casó a la Virgen del Rosario de Villanueva de la Jara; a su hijo D. Andrés le legó una cadena de oro de 50 doblones; a su hija, dos fuentes de plata con fajas doradas; y a su yerno, un cabestrillo de oro con una cruz de esmeraldas; a su cuñada Dña. M ${ }^{a}$ Clara Poblete y a su sobrina Dña. Juana Valero les dejó una alhaja a cada una; a su cuñada Dña. Gregoria Valdés, mujer de D. Julián Cerdán, mandó que se le entregase un cintillo de diamantes y otro igual a Dña. María Márquez, mujer de D. Marcos Morales y Jaraba ${ }^{41}$. La posesión de objetos de oro y plata destinados al adorno personal estaba estrechamente relacionada con los niveles de riqueza de la familia, pero también con los deseos de mostrarse en sociedad ${ }^{42}$. Doña Isabel Cerdán, cuñada de Dña. Esperanza, también había dejado en su testamento distintos bienes como sus vestidos y objetos devocionales a sus hermanas y cuñadas, entre los que se hallaban una lámina de ágata guarnecida o una joya de cristal decorada con filigrana de oro $^{43}$. Por el contrario, su hermano, el arzobispo Valero, se caracterizó por una profunda religiosidad y una austeridad franciscana desde sus primeros momentos como cura en Villanueva de la Jara, donde se retiraba a la habitación más desocupada del bullicio de la casa, juntó allí una copiosa y selecta librería. Los muebles eran seis sillas viejas, una mesa y sobre ella un crucifixo muy devoto [...] Su cama era un

\footnotetext{
${ }^{41}$ Archivo Histórico Provincial de Cuenca (en adelante A.H.P.C.) Sección Protocolos, P-1187. 42 J.M. BARTOLOMÉ BARTOLOMÉ (2013). "Patrimonios, condiciones de vida y consumo. La burguesía administrativa y las profesiones liberales en León”. En García Fernández, M. (coord.). Cultura material y vida cotidiana moderna: escenarios. Madrid: Sílex, p. 79.

${ }^{43}$ A.H.P.C. Sección Protocolos, P-1195.
} 
colchón sobre unas tablas y unas mantas muy pobres... ${ }^{44}$.

Otros ejemplos de consumo diferenciado los encontramos entre algunos miembros de la élite conquense como Dña. Ana Domínguez de Córdoba, quien entregó a sus sobrinas, Dña. Jacinta Domínguez, seis almohadas de terciopelo carmesí y damasco; a Dña. María Domínguez, un brasero, alfombra, perendengues de oro y aljófar; a Dña. Dorotea López, seis almohadas de terciopelo carmesí y una anguarina de paño; y a Dña. Catalina López, un trencillo de oro con diamantes y en medio una piedra turca ${ }^{45}$.

En 1707 Dña. María Antonia de Montemayor y Córdoba, marquesa de Ciadoncha, le deja a su marido el marqués, D. Francisco Nicolás Crema y Sandoval, un velón de plata grande con seis mecheros con un peso de 15 libras; a su hijo mayor, D. Francisco Rafael, un taller de mesa de plata sobredorada con salero, pimentero, azucarero, aceitera y vinagrera; y a su hija, otro taller de plata blanca y todas sus joyas y sortijas. A sus cuñados, D. Joaquín Crema, una bandeja de plata de 30 onzas; a D. Ventura Crema, una bandeja de 20 onzas; a Dña. Ana María de Silva, un relojito pequeño de oro; a D. Pedro Losa un bernegal de plata; y a su prima Dña. Teresa Velázquez, una pililla de plata para agua bendita ${ }^{46}$.

Dña. Inés Muñoz Carrillo de Mendoza, marquesa de Villel, lega en su testamento un vestido carmesí listado de negro y un jubón de raso liso bordado de colores a su sobrina; a la mujer de su tío, Dña. Ana Valterra Blanes, un reloj de porcelana y oro; a la Virgen que se encuentra en la ermita de San Antonio de Cuenca, una mantilla color de fuego con encaje de oro y plata; una firma de Santa Teresa de Jesús guarnecida de oro y perlas a la Virgen del altar mayor del convento de San Francisco de Cuenca; a la Virgen del convento de la Concepción Angélica, una basquiña de tela de plata; y a la Virgen de Loreto, una guardapiés de tela verde con tres encajes de oro y plata para un vestido $^{47}$.

Dña. Antonia Cañaveras Guadarrama, hija de D. Juan Cañaveras, regidor de Huete y madre de D. José Sancha y Ayala, regidor de Cuenca, le deja a su nuera, Dña. Quiteria Antonia Salonarde, uno de los objetos más curiosos de todos los que hemos podido catalogar: un pájaro de oro en su jaula guarnecido de esmeraldas, así como

44 J. IGLESIAS GÓMEZ (1998). Vida de Don Francisco Valero y Losa (1664-1720)..., op. cit., p. 29.

${ }^{45}$ A.H.P.C. Sección Protocolos, P-1225.

${ }^{46}$ A.H.P.C. Sección Protocolos, P-1228.

${ }^{47}$ A.H.P.C. Sección Protocolos, P-1179. 
distintos cuadros y una cruz de cristal con remates de filigrana de oro a otros miembros de su familia ${ }^{48}$.

La presencia de bienes de consumo que denotan un estatus diferencial de los individuos lo podemos atestiguar a través de otros documentos como son las capitulaciones matrimoniales, donde además de cantidades elevadas de dinero en efectivo o en bienes inmuebles, aparecen joyas cuya descripción muestra lo relevante del objeto para quien lo entregaba como dote. Dña. María Josefa Sánchez Ramírez de Torres aporta en su dote joyas con 270 diamantes valoradas en 8000 reales $^{49}$. Del mismo modo, en las capitulaciones firmadas en plena guerra de Sucesión en 1705 entre dos de las ramas de la familia Cerdán de Landa para el matrimonio entre D. Francisco Javier Cerdán de Landa, hijo de D. Dionisio Cerdán, y Dña. Juana María Cerdán, hija de D. Juan Cerdán, regidor de Cuenca, ambos cónyuges se entregan, además de rentas y bienes, una joya para sellar la unión. Dña. Juana le entrega a su primo y futuro esposo una sortija de oro y esmeraldas y D. Francisco Javier a ella, una joya de oro y perlas, una y otra de valor considerable ${ }^{50}$. La familia Cerdán de Landa alcanza durante la guerra una posición privilegiada entre la élite conquense y los objetos que consume dan buena muestra de ello, consiguiendo plasmar el proceso de ascenso social a través de unas prácticas de consumo de productos de lujo.

La familia Velasco y de la Cueva era otra de las que se distingan por poseer objetos de lujo en Cuenca. Dña. Isabel de Velasco, hermana y tía del XII y XIII condes de Siruela, respectivamente, a su muerte lega una joya de oro esmaltado a su sobrino el conde; todas las alhajas de plata a su hermana Dña. Estefanía de Velasco, dama de la reina; a su sobrina Dña. Leonor de Velasco, marquesa de Caracena del Valle, un tocador con su espejo; y a su sobrino D. Gabriel de Velasco, un escritorio de ébano y marfil $1^{51}$.

Pero si hay un personaje que llame la atención por la calidad de los objetos que posee ese es D. Antonio de Velasco y de la Cueva, XIII conde de Siruela. D. Antonio durante la contienda pasará de mantenerse sin una significación política manifiesta a favor del archiduque al principio de la guerra de Sucesión, (hay que indicar aquí que su yerno, el conde de Cifuentes, era uno de los principales austracistas castellanos desde el comienzo de la contienda), a trasladarse a Barcelona en 1710 a la Corte de

\footnotetext{
${ }^{48}$ A.H.P.C. Sección Protocolos, P-1184.

${ }^{49}$ A.H.P.C. Sección Protocolos, P-1183.

${ }^{50}$ A.H.P.C. Sección Protocolos, P-1206.

${ }^{51}$ A.H.P.C. Sección Protocolos, P-1171.
} 
Carlos III del que recibirá el honor de la grandeza de España al año siguiente. Este cambio de actitud le conllevará el embargo de sus bienes ${ }^{52}$ por parte de Felipe V y no le serán restituidos hasta $1721^{53}$. Pese al menoscabo que sufrió por el mencionado embargo, a su muerte en 1730 D. Antonio de Velasco poseía en su palacio de Madrid unos bienes por valor de más de 116000 reales. Estos objetos estaban compuestos por numerosos muebles de valor, ropa blanca, cobres, coches, armas, vestidos, pinturas, tapices, ornamentos religiosos, joyas y objetos de plata por un peso de 77 libras de plata (más de $35 \mathrm{~kg}$.), valoradas al peso en 21000 reales, a razón de 9 reales la onza, y tasados los objetos labrados en más de 37000 .

Entre ellos, destacaremos aquellos por su especial valor simbólico en cuanto a detentadores de un estatus diferenciado, como las dos estampillas de plata que utilizaba para firmar los documentos en los últimos años de su vida, debido a que su avanzada edad y el deterioro físico consiguiente le imposibilitaban firmar de su puño y letra, así como los que constituyen bienes de un extraordinario lujo. Entre estos últimos destaca el más caro de todos cuantos fueron tasados como fue

“...una joya broche de oro que llaman porta mantón que según la tasa que está con ella dada por Juan Muñoz contraste en esta Corte en 16 de agosto de 1726 expresa tener los reversos tallados compuesta de hojas y cogollos con una rosa grande en medio y cuatro más pequeñas a los lados y a la parte de arriba un cogollo de seis engastes, los tres pendientillos y una mariposa encima y otros dos a los lados y un joyel pendiente. Y otros ocho pendientillos a los lados guarnecido todo con 579 diamantes y 43 esmeraldas, la mayor que hace medio cuya joya está en una caja forrada de terciopelo encarnado y dicha joya está legada a Nra. Sra. del Sagrario sita en la iglesia catedral de la ciudad de Cuenca..."

Esta joya estuvo tasada en más de 11700 reales y al ser legada a la Virgen del Sagrario pone de manifiesto que, pese a acabar sus días en Madrid, el conde de Siruela seguía manteniendo una vinculación con Cuenca ${ }^{54}$. La donación de objetos específicos dentro de las mandas pías tenían, como en este caso, destinatarios muy concretos como distintas imágenes o instituciones religiosas ${ }^{55}$; así lo muestra el hecho de que esta imagen recibiera donaciones de otros miembros ilustres de Cuenca, como Dña. Agustina de Jaraba Carrillo, quien legó a la Virgen del Sagrario una alfombra

\footnotetext{
52 A.H.N. Sección Estado, Leg. 2973.

${ }^{53}$ A.H.N. Sección Nobleza, Fernán Núñez, C. 101, D. 10.

${ }^{54}$ A.H.N. Sección Nobleza, Fernán Núñez, C. 17, D. 10.

${ }^{55}$ M. GARCÍA FERNÁNDEZ (1995). Herencia y patrimonio familiar en la Castilla del Antiguo Régimen (1650-1834). Valladolid: Universidad de Valladolid, p. 137.
} 
turca, unas perlas, una joya de la Soledad, una joya de oro y perlas con una lámina de la Sagrada Familia, por un lado, y por el otro, una reliquia de San Adrián ${ }^{56}$.

Además de las distintas joyas de oro y plata presentes en el inventario de bienes del conde, destacan los objetos exóticos como las más de ochenta piezas de porcelana china con la que contaba en su haber, los siete cocos guarnecidos con pies de plata, distintos vestidos a la francesa, unas sillas de Inglaterra valoradas en 1200 reales, o un bufete de ágatas de varios colores tasado en más de 1000, distintos muebles de maderas exóticas como el ébano o la caoba, obras de arte (pinturas, esculturas, relicarios, etc.) por un valor superior a los 5700 reales, colgaduras de cama que alcanzaban los 1000 reales o juegos de cortinas que incluso superaban los 2000 reales, como el juego que regaló a la Virgen de la Soledad de Cuenca ${ }^{57}$.

Otro de los bienes distintivos de la posición social del conde lo constituyen sus vestidos. Entre ellos contaba con uno de militar o a la francesa que se habían generalizado en la Corte en la primera mitad del siglo XVIII ${ }^{58}$, valorado en 600 reales, realizado en paño fino de color musco, compuesto de casaca, chupa y calzón forrado en siguiri ( $\operatorname{segrí}^{59}$ ) y la chupa y las vueltas de la casaca eran de espumillón; otro vestido grana valorado en 500 reales, con la casaca y el calzón forrados de raso liso y la chupa de terciopelo rizado encarnado y color de porcelana; y otros dos más de carro de oro de seda color perla valorados en otros 500 reales cada uno, el primero con la chupa y las vueltas de la casaca de moer de aguas forrado de tafetán verde y el segundo con las vueltas de la casaca en ormesí de aguas ${ }^{60}$. En 1718 otro de los miembros de la élite conquense, D. Sebastián Vicente de Borja, regidor de Cuenca y de Madrid y gentilhombre de Boca de Su Majestad, presumía de seis vestidos a lo militar y tres casacas de brocato ${ }^{61}$. El atuendo se plasmaba como un signo ampliamente reconocido

\footnotetext{
${ }^{56}$ A.H.P.C. Sección Protocolos, P-1154.

${ }^{57}$ A.H.N. Sección Nobleza, Fernán Núñez, C. 17, D. 10.

${ }^{58}$ A. GIORGI (2013). De la vanidad y de la ostentación. Imagen y representación del vestido masculino y el cambio social en España, siglos XVII-XIX. Tesis doctoral. Murcia: Universidad de Murcia, p. 482.

59 Tela de seda fuerte, del grueso o cuerpo del tafetán doble, DÁVILA, R., DURÁN, M. y GARCÍA, M., (2004). Diccionario histórico de telas y tejidos. Salamanca: Junta de Castilla y León, p. 179.

${ }^{60}$ A.H.N. Sección Nobleza, Fernán Núñez, C. 17, D. 10.

${ }^{61}$ A. GIORGI (2012). "Vestir a la española y vestir a la francesa. Apariencia y consumo de la población madrileña del siglo XVIII". En Bartolomé, J.M y García, M. (dirs.). Apariencias contrastadas: contraste de apariencias. Cultura material y consumos de Antiguo Régimen. León: Universidad de León, p. 162.
} 
de la ocupación de los individuos como marcadores de su identidad social ${ }^{62}$. En el caso del conde de Siruela estos bienes son especialmente relevantes, al no aparecer entre sus ropas las golillas y los trajes a la española que podrían suponerse a un noble que se había decantado por el partido austracista durante la guerra de Sucesión y que había obtenido la grandeza de España para su casa de manos del archiduque Carlos. La decisión de D. Antonio de Velasco y de la Cueva de no acompañar al archiduque a Viena tras la evacuación de Barcelona y la de regresar a Castilla tras la guerra, así como el perdón otorgado por Felipe V tras la paz de Viena de 1725, favorecieron la reinserción de la casa de Siruela entre la nobleza española lo que habría de plasmarse en la imagen y el vestido del conde. La utilización de determinadas prendas supuso un innegable papel en el lento cambio ideológico colectivo de la sociedad castellana ${ }^{63}$. El vestido había supuesto rasgos nacionalistas o de inclinación política, como demuestra la impopularidad desatada hacia $\mathrm{M}^{\mathrm{a}}$ Luisa Gabriela de Saboya por el rechazo del tontillo ${ }^{64} \mathrm{o}$ el uso de la vestimenta a la española por los partidarios austracistas durante la guerra de Sucesión.

Otro apartado corresponde a los tapices, entre los que destaca un conjunto valorado en 8400 reales compuesto por ocho paños donde se mostraba la fábula de Diana y otra colección todavía más grande representando la historia de Tobías con una dimensión total de 55 anas y media de largo y seis de alto valorada en 14650 reales. Así como los espejos de los que el conde poseía dos grandes valorados en 3000 reales y todos los del inventario fueron tasados en más de 7700. Las tasaciones se hacían en función del valor de los objetos, pero también podían entrar en juego otros factores como la demanda que tuviesen en cada lugar ${ }^{65}$, siendo en este caso la Corte uno de los lugares

\footnotetext{
${ }^{62}$ M.M. BIRRIEL SALCEDO (2013). "Clasificando el mundo. Los libros de trajes en la Europa del siglo XVI”. En García Fernández, M. (coord.). Cultura material y vida cotidiana moderna: escenarios. Madrid: Sílex, p. 276.

${ }^{63}$ M. GARCÍA FERNÁNDEZ (2005). "La presencia de productos textiles con 'denominación de origen francés e inglés' en Castilla. Evolución de los intercambios comerciales entre la Paz de Utrecht y Trafalgar”. En A. Guimerá y V. Peralta (coords.). El Equilibrio de los Imperios: de Utrecht a Trafalgar, II. Madrid: Fundación Española de Historia Moderna, p. 281

${ }^{64}$ M. GARCÍA FERNÁNDEZ (2014). "Individuo y consumo de apariencia: replanteamientos ilustrados en clave social”. En García Fernández, M. y Chacón Jiménez, F. (dirs.). Ciudadanos y familias. Individuo e identidad sociocultural hispana (siglos XVII-XIX). Valladolid: Universidad de Valladolid, p. 341.

$65 \mathrm{M}^{\mathrm{a}}$ M. GUERRERO CANO y $\mathrm{M}^{\mathrm{a}}$ M. BARRIENTOS MÁRQUEZ (2013). "La documentación de bienes de difuntos y el estudio de la vida cotidiana”. En García Fernández, M. (coord.). Cultura material y vida cotidiana moderna: escenarios, Madrid: Sílex, p. 30.
} 
donde mayor demanda se podía encontrar de estos objetos de lujo. Los tapices eran un verdadero marcador de las cimas de la jerarquía social; durante el siglo XVII los presidentes de tribunales supremos franceses llegaban a acaparar más de trescientas piezas de tapicería ${ }^{66}$. Otro de los bienes accesible a un muy reducido número de individuos eran los coches de caballos de los que el conde poseía dos forlones, uno valorado en 5000 reales, tapizado en terciopelo rojo, cubierto y cerrado por siete cristales, y otro tapizado en terciopelo azul y con tres cristales valorado en 2500 reales ${ }^{67}$. En 1691 había sido limitado el uso de coches a los individuos de una marcada posición social, prohibiéndolo para aquellos cuya condición era inferior, como alguaciles de Corte, escribanos, notarios, procuradores, mercaderes, etc. ${ }^{68}$ La posesión de coches se había convertido en la España de los últimos Habsburgo en el acicate del pugilato de vanidad y ostentación ${ }^{69}$, tal era así que el arzobispo de Toledo, D. Francisco Valero, haciendo gala de su proverbial estima hacia la pobreza evangélica, como obispo de Badajoz había declinado su uso en sus visitas a los distintos pueblos del obispado y ya como arzobispo de la sede primada se vio obligado a hacer uso de seis carrozas que compusieron la comitiva que lo condujo desde el palacio arzobispal en Madrid hasta el palacio del Retiro, donde celebró la confirmación de los infantes Felipe, Fernando y Carlos en 1716. La ceremonia estuvo marcada por la exhibición del lujo correspondiente a un acto de representación tan relevante para la Monarquía, lo que se contraponía con los ideales del arzobispo, y tuvo que ser el Cabildo quien en esta ocasión arregló las cosas por la mayor parte, para que el venerable arzobispo compareciese en aquel acto con el culto y decencia que el acto requería. La carroza que ocupó el arzobispo se compró por orden del Cabildo; la segunda fue regalo del duque de Béjar; el caballo que montaba el caballerizo mayor era del conde de Altomira; casi todas las mulas y guarniciones fueron franqueadas por el duque del Arco y el marqués de San Juan; y el anillo y el pectoral que ostentaba era préstamo del marqués de Ariza. Una vez finalizada la ceremonia, y en consonancia con sus ideales, el arzobispo mandó que la carroza recibida del duque de Béjar fuese vendida y su producto repartido entre los pobres; la carroza de respeto regalada y las libreas

\footnotetext{
${ }^{66}$ M. FIGEAC (2015). “La vida material de la nobleza francesa...”, op. cit., p. 68.

${ }^{67}$ A.H.N. Sección Nobleza, Fernán Núñez, C. 17, D. 10.

${ }^{68}$ A. LÓPEZ ÁlVAREZ (2007). Poder, lujo y conflicto en la Corte de los Austrias. Coches, carrozas y sillas de mano, 1550-1700. Madrid: Polifemo, p. 309.

${ }^{69}$ J. DELEITO Y PIÑUELA (1946). La mujer, la casa y la moda (en la España del rey poeta). Madrid: Espasa-Calpe, p. 257.
} 
vendidas y su importe entregado a los hospitales del Arzobispado ${ }^{70}$, como muestra de su rechazo a la ostentación y al lujo.

El inventario post mortem del conde de Siruela cataloga los bienes siguiendo categorías: madera, dinero, joyas, etc., a diferencia de los inventarios de finales de siglo donde en muchos de ellos se describen los bienes distribuidos por habitación ${ }^{71}$, por lo que nos ha resultado imposible distinguir qué objetos ocupaban cada sala. El único espacio de las casas del conde que hemos podido reconstruir en buena medida a través de los objetos que se guardaban en él ha sido el oratorio del palacio. Presidía la estancia una escultura de la Virgen del Carmen de tres cuartas de alta y coronada de plata. A la imagen la acompañaban otras dos esculturas de poco más de una tercia, una de San José con el Niño y otra de San Antonio. Las pinturas que decoraban el oratorio estaban formadas por un cuadro de Nra. Sra. del Pópulo de cinco cuartas de alto y una vara de ancho, otro de Santa Bárbara y otra de la Virgen del Sagrario, patrona de Cuenca. D. Antonio seguía vinculado a su ciudad de nacimiento a través de las imágenes de los patrones de Cuenca, como en este caso en el oratorio, además de las de San Julián, quien aparecía representado en dos pinturas en otras estancias del palacio. En cuanto a los objetos dedicados a la liturgia, aparecen una cruz de Jerusalén embutida en nácar, un cáliz con su patena y cucharita de plata, además de la ropa para oficiar (casulla, estola y manípulo de damasco encarnado y forrado en holandilla con guarnición de galón de oro, dos amitos de cambrayón, un alba con encajes y distintos paños para el cáliz entre otros) $)^{72}$. Otros de los objetos que componían el mobiliario de la sala eran la mesa de altar con una grada cubierta de damasco, un misal con su atril, un relicario con cinco agnus con diferentes rosas de mano y seis ramilleteros de flores con sus macetas pintados de verde y dorado, contra los que ya clamaba en el primer tercio del siglo XVII Pedro Fernández de Navarrete en su Conservación de monarquías. Discursos políticos sobre la gran consulta que el Consejo hizo al Señor Rey don Felipe Tercero (Madrid, 1626), donde criticaba que ya no se juzga qué huelen las flores, si los ramilleteros son de barro: y así los hacen de plata, o de otra manera más costosa [...] no sólo los ramilleteros son de plata, sino que aún se hacen los tiestos

70 J. IGLESIAS GÓMEZ (1998). Vida de Don Francisco Valero y Losa..., op. cit., pp. 108 y 109.

${ }^{71}$ J. CRUZ VALENCIANO (2014). El surgimiento de la cultura burguesa. Personas, hogares y ciudades en la España del siglo XIX. Madrid: Siglo XXI, , p. 128.

72 A.H.N. Sección Nobleza, Fernán Núñez, C. 17, D. 10. 
y potes para las hierbas de este tan estimado metal ${ }^{73}$, como muestra del lujo ostentoso de las clases privilegiadas castellanas. El oratorio del conde mantenía las características típicas de este tipo de estancias de época de los Austrias y que serían sustituidas progresivamente a lo largo del siglo XVIII por estructuras más acordes a la nueva estética proveniente de Francia ${ }^{74}$.

\section{CONCLUSIÓN}

Durante un periodo bélico como la Guerra de Sucesión, se comprende que la población tuviera como principal preocupación y práctica de consumo la subsistencia, algo que se expresaba con tres consignas: guardar el grano que se tenía, fijar tasas y denunciar a los acaparadores ${ }^{75}$. Y más en una ciudad como Cuenca donde el trigo se tenía que comprar fuera. Garantizar el abasto se convierte así en una prioridad para las autoridades municipales que tienen que hacer frente a la demanda de la población de la ciudad y de las distintas tropas que se alojaron en Cuenca durante la guerra, en tránsito hacia sus cuarteles o como guarnición de defensa, valiéndose de la intervención del obispo, del Cabildo y de los individuos más adinerados de la élite concejil. Como hemos visto, la insuficiencia provocará a lo largo de la guerra diversos problemas de abastecimiento que llegarán a su punto culmen en 1709, año en que la ciudad tiene que abastecerse desde el reino de Aragón a unos precios tan elevados que hacen imposible el hecho de poder recuperar el dinero invertido. La deuda contraída por la ciudad solo se podrá ver saldada a través de la subida del precio del pan hasta unos límites que la población no puede pagar, y menos en un momento de crisis de subsistencia como el vivido en 1709. Estas circunstancias provocarán que la población muestre su descontento por las calles de la ciudad protagonizando el primer tumulto del siglo XVIII causado por la carestía del trigo. La revuelta obligó a las autoridades locales a dar marcha atrás en las decisiones que habían tomado por miedo a una reacción entre la población de la ciudad todavía de mayores dimensiones.

Por otro lado, los individuos más relevantes política y socialmente se ven afectados en menor medida por la subida del precio del trigo al contar con reservas que llegan a poner a disposición del abastecimiento público ante las peticiones de las autoridades

\footnotetext{
${ }^{73}$ J. VEGA (2005). "Transformación del espacio doméstico en el Madrid del siglo XVIII: del oratorio y el estrado al gabinete". Revista de Dialectología y Tradiciones Populares, LX, $\mathrm{n}^{\circ} 2$, p. 192.

${ }^{74}$ Ibídem, pp. 207-212.

75 P. VILAR (1982). Hidalgos, amotinados y guerrilleros. Pueblo y poderes en la historia de España. Barcelona: Crítica, p. 77.
} 
reales. Pese a las numerosas voces en contra el lujo y la ostentación, como la del arzobispo Valero, las élites conquenses realizaban prácticas de consumo caracterizadas por la posesión de productos que marcaban su diferenciación social con respecto al común como objetos de plata, oro, maderas nobles o porcelanas entre otros. De tal manera que el ascenso social de los individuos que apoyaron a Felipe V, como los Cerdán de Landa, también se plasmaba en los objetos de los que eran poseedores a través de un consumo diferenciado, como hemos podido comprobar en el caso de Dña. Esperanza Valero. Por lo que respecta a los individuos austracistas, representados por D. Antonio de Velasco y de la Cueva, XIII conde de Siruela, hemos constatado que pese a su afinidad durante la guerra de Sucesión por el archiduque Carlos y las consiguientes represalias tras la finalización del conflicto, al final de sus días contaba entre sus haberes con un número muy estimable de objetos de lujo que lo situaban en un puesto privilegiado de la élite y había asumido los nuevos gustos franceses en su indumentaria como muestra de su reinserción en la Corte borbónica, puesto que, como defiende Rafaela Sarti, el vestido, en mayor medida que otros bienes, fue la imagen de luchas simbólicas de las que salieron nuevas definiciones ${ }^{76}$. La etiqueta a la francesa había sido adoptada por los grupos más cercanos a la Corte y desde allí se había difundido hasta los grupos en proceso de movilidad social ascendente ${ }^{77}$.

La guerra de Sucesión se convierte así en un escenario donde poder visualizar las diferentes pautas de consumo en un momento de crisis de subsistencia y las dificultades de abastecimiento de aquellos productos básicos que habrían de garantizar la supervivencia de la mayoría de la población y de los soldados, especialmente del trigo, y nos manifiesta una marcada diferenciación social en cuanto a los hábitos de las élites que cuentan, en unos casos, con el acceso a un mercado de bienes de lujo que caracteriza su estatus y, en otros, se muestra como signo de su recientemente alcanzado ascenso social.

\footnotetext{
${ }^{76}$ R. SARTI (2002). Vida en familia. Casa, comida y vestido en la Europa Moderna. Barcelona: Crítica, p. 267.

77 A. GIORGI (2014). "La difusión del vestido francés en la villa de Madrid durante la segunda mitad del siglo XVIII”. En García Fernández, M. y Chacón Jiménez, F. (dirs.). Ciudadanos y familias. Individuo e identidad sociocultural hispana (siglos XVII-XIX). Valladolid: Universidad de Valladolid, p. 426.
} 


\section{BIBLIOGRAFÍA}

AGUIRRE MARTÍN, C. (2000). Los avatares de la guerra de Sucesión en El Burgo de Osma (1700-1714). Soria: Excma. Diputación Provincial de Soria.

ALBEROLA ROMÁ, A. (1999). "Abasto urbano y protesta popular en tierras valencianas durante el siglo XVIII”. En De Bernardo Ares, J.M. y González Beltrán, J.M. (eds.). La Administración Municipal en la Edad Moderna, II, Cádiz: Universidad de Cádiz, pp. 331-339. (2004). "Oscilaciones climáticas y coyuntura agrícola en tierras valencianas durante el reinado de Felipe V". En Serrano, E. (ed.). Felipe Vy su tiempo. Zaragoza: Institución Fernando el Católico, pp. 201-224.

ANDÚJAR CASTILLO, F. (2015). "Negocios privados, cargos públicos: el recurso a testaferros en la etapa del cambio dinástico". En Solbes, S. y Dubet, A. (coords.). "Actores políticos y actores privados en el gobierno de la Hacienda". Revista Tiempos Modernos, 8, $\mathrm{n}^{\circ} 30$.

ARANDA PÉREZ, F.J. y GARCÍA RUIPÉREZ, M. (1999). "Posturas y penas en el mercado. Los fieles ejecutores en Castilla en la Edad Moderna”. En De Bernardo Ares, J.M. y González Beltrán, J.M. (eds.). La Administración Municipal en la Edad Moderna, II. Cádiz: Universidad de Cádiz, pp. 349358.

ARMILLAS VICENTE, J.A. y SANZ CAMAÑES, P. (1996). "El municipio aragonés en la Edad Moderna: Zaragoza, caput regni". En De Bernardo Ares, J.M. y Martínez Ruiz, E. (eds.). El municipio en la España Moderna. Córdoba: Universidad de Córdoba, pp. 43-72.

BARTOLOMÉ BARTOLOMÉ, J. M. (2013). "Patrimonios, condiciones de vida y consumo. La burguesía administrativa y las profesiones liberales en León". En García Fernández, M. (coord.). Cultura material y vida cotidiana moderna: escenarios. Madrid: Sílex, pp. 73-89.

BIRRIEL SALCEDO, M.M. (2013). "Clasificando el mundo. Los libros de trajes en la Europa del siglo XVI”. En García Fernández, M. (coord.). Cultura material y vida cotidiana moderna: escenarios. Madrid: Sílex, pp. 261-278.

DE CASTRO, C. (1987). El pan de Madrid. El abasto de las ciudades españolas del Antiguo Régimen. Madrid: Alianza Universidad. (2004). A la sombra de Felipe V. José de Grimaldo, ministro responsable (1703-1726). Madrid: Marcial Pons,. 
CREMADES GRIÑÁN, C. Ma (1984). Alimentación y consumo en la ciudad de Murcia durante el siglo XVIII (1701-1766). Murcia: Universidad de Murcia.

CRUZ VALENCIANO, J. (2014). El surgimiento de la cultura burguesa. Personas, hogares y ciudades en la España del siglo XIX. Madrid: Siglo XXI.

DANTÍ I RIU, J. (2012). "La diversidad agraria en la España moderna: Campo, campesinos y actividades productivas”. En Pérez Álvarez, Mª J. y Rubio Pérez, L. M. (eds.). Campo y campesinos en la España Moderna. Culturas políticas en el mundo hispánico, I. León: Fundación Española de Historia Moderna, pp. 213-253.

DELEITO Y PIÑUELA, J. (1946). La mujer, la casa y la moda (en la España del rey poeta). Madrid Espasa-Calpe.

DOMÍNGUEZ ORTIZ, A. (1984). Sociedad y Estado en el s. XVIII español, Barcelona: Crítica.

FIGEAC, M. (2015). "La vida material de la nobleza francesa, entre el 'Gran Siglo' y el Siglo de las Luces: una lectura de las diferenciaciones sociales en el seno del estamento nobiliario". Revista Investigaciones Históricas: Época moderna y contemporánea, pp. 67-84.

GARCÍA FERNÁNDEZ, M. (1995). Herencia y patrimonio familiar en la Castilla del Antiguo Régimen (1650-1834). Valladolid: Universidad de Valladolid. (2005). "La presencia de productos textiles con 'denominación de origen francés e inglés' en Castilla. Evolución de los intercambios comerciales entre la Paz de Utrecht y Trafalgar”. En A. Guimerá y V. Peralta (coords.). El Equilibrio de los Imperios: de Utrecht a Trafalgar, II. Madrid: Fundación Española de Historia Moderna, pp. 277-294.

(2013). "Prefacio. Cultura e identidades: nuevos horizontes y planteamientos de futuro". En García Fernández, M. (coord.). Cultura material y vida cotidiana moderna: escenarios. Madrid, Sílex, pp. 9-22.

(2014). "Individuo y consumo de apariencia: replanteamientos ilustrados en clave social". En García Fernández, M. y Chacón Jiménez, F. (dirs.).

Ciudadanos y familias. Individuo e identidad sociocultural hispana (siglos XVII-XIX). Valladolid: Universidad de Valladolid, p. 337-356.

GARCÍA MARÍN, J.Ma (1985). "La reconstrucción de la administración territorial y local en la España del siglo XVIII”. En La época de los primeros borbones, I, La nueva Monarquía y su posición en Europa (1700-1759). Madrid: Espasa-Calpe, pp. 179-221. 
GIORGI, A. (2012). "Vestir a la española y vestir a la francesa. Apariencia y consumo de la población madrileña del siglo XVIII". En Bartolomé, J. M y García, M. (dirs.). Apariencias contrastadas: contraste de apariencias. Cultura material y consumos de Antiguo Régimen. León: Universidad de León, pp. 157-172.

(2013). De la vanidad y de la ostentación. Imagen y representación del vestido masculino y el cambio social en España, siglos XVII-XIX. Tesis doctoral. Murcia: Universidad de Murcia.

(2014). "La difusión del vestido francés en la villa de Madrid durante la segunda mitad del siglo XVIII". En García Fernández, M. y Chacón Jiménez, F. (dirs.). Ciudadanos y familias. Individuo e identidad sociocultural hispana (siglos XVII-XIX). Valladolid: Universidad de Valladolid, pp. 425-435.

GUERRERO CANO, Ma M. y BARRIENTOS MÁRQUEZ, Ma M. (2013). "La documentación de bienes de difuntos y el estudio de la vida cotidiana". En García Fernández, M. (coord.). Cultura material y vida cotidiana moderna: escenarios. Madrid: Sílex, pp. 23-38.

GUILLAMÓN ÁLVAREZ, F. J. (1988-1990). “Algunos presupuestos metodológicos para el estudio de la administración: el régimen municipal en el siglo XVIII". Revista de Historia Moderna, Anales de la Universidad de Alicante, 8-9, pp.59-74.

IGLESIAS GÓMEZ, J. (1998). Vida de Don Francisco Valero y Losa (1664-1720) Arzobispo de Toledo, Madrid: La Librería.

LÓPEZ ÁlVAREZ, A. (2007). Poder, lujo y conflicto en la Corte de los Austrias. Coches, carrozas y sillas de mano, 1550-1700. Madrid: Polifemo.

MARCOS MARTÍN, A. (1996). "Historia y desarrollo: el mito historiográfico de la burguesía”. En Enciso Recio, L.M. (coord.). La Burguesía Española en la Edad Moderna, I. Valladolid: Universidad de Valladolid-Fundación Duques de Soria-V Centenario Tratado de Tordesillas, pp. 15-34.

MARTÍNEZ CHACÓN, E. (1985). "Estudio preliminar". De Efectos perniciosos del lujo: Las cartas de D. Manuel Romero del Álamo al Memorial Literario de Madrid (1789). Oviedo: Universidad de Oviedo, pp. 9-48.

PARDO PARDO, M.R. (2000). "Base socioeconómica de los siglos XVI y XVII" y "Transformaciones económicas bajo el signo del reformismo borbónico". En Pardo Pardo, M. R. (coord.). Historia Económica de Castilla-La Mancha (siglos XVI-XX). Madrid: Celeste, pp. 29-36. 
PÉREZ SAMPER, Ma A. (1999). "El pan en la Barcelona moderna: Poder municipal y abastecimiento”. En De Bernardo Ares, J. M. y González Beltrán, J. M. (eds.). La Administración Municipal en la Edad Moderna, II, Cádiz: Universidad de Cádiz, pp. 407-420.

(2012). "La alimentación catalana en la Edad Moderna, según el Libre dels secrets d'agricultura, casa rústica i pastoril de Miquel Agustí". En Pérez Álvarez, M J. y Rubio Pérez, L.M. (eds.). Campo y campesinos en la España Moderna. Culturas políticas en el mundo hispánico, II. León: Fundación Española de Historia Moderna, pp. 1483-1496.

RICO GIMÉNEZ, J. (2000). "Estudio preliminar". De Sempere y Guarinos, Historia del lujo y de las leyes suntuarias de España. Valencia: Institució Alfons el Magnànim, pp. 9-66.

RODRÍGUEZ DE GRACIA, H. (2001). "La Guerra de Sucesión. El crecimiento de los impuestos y sus consecuencias en Jaén". En La Guerra de Sucesión en España y América, X Jornadas Nacionales de Historia Militar. Madrid: Deimos, pp. 737-752.

RODRÍGUEZ HERNÁNDEZ, A. J. (2011). Los tambores de Marte. El reclutamiento en Castilla durante la segunda mitad del siglo XVII (16481700). Valladolid: Universidad de Valladolid-Castilla Ediciones.

SARTI, R. (2002). Vida en familia. Casa, comida y vestido en la Europa Moderna. Barcelona: Crítica.

VEGA, J. (2005). "Transformación del espacio doméstico en el Madrid del siglo XVIII: del oratorio y el estrado al gabinete", Revista de Dialectología y Tradiciones Populares, LX, nº 2, pp. 191-226.

VILAR, P. (1982). Hidalgos, amotinados y guerrilleros. Pueblo y poderes en la historia de España. Barcelona: Ed. Crítica.

DE VRIES, J. (2009). La revolución industriosa. Consumo y economía doméstica desde 1650 hasta el presente. Barcelona: Crítica. 


\title{
SASTRES Y ROPEROS EN MADRID: LA IMAGEN COTIDIANA DE LA MODA DEL SIGLO XVIII'
}

\section{NEW-CLOTHIER MERCHANTS' AND TAILORS' IN MADRID: THE EVERYDAY IMAGE OF FASHION IN XVIIITH CENTURY.}

\author{
ARIANNA GIORGI \\ Universidad de Murcia \\ arianna.giorgi@gmail.com
}

Recibido: $12 / 09 / 2016$

Aceptado: 12/12/2016

RESUMEN: ¿Cómo vestían los sastres? ¿Cuál era la identidad indumentaria de los mercaderes de ropería de nuevo? Estas sencillas preguntas corresponden a aspectos cotidianos de los miembros del sector textil, que aún se desconocen en la actualidad. Al ser el grupo profesional encargado de la elaboración de los vestidos $\mathrm{y}$, por consiguiente, de la difusión de los nuevos patrones indumentarios, nos interesa conocer hasta qué punto los compartían o utilizaban. Con el fin de resolver estas cuestiones, nos apoyaremos en la imagen vestimentaria que les caracterizaba como grupo profesional y social. A través de las referencias del Archivo Histórico de Protocolo de Madrid, pretendemos averiguar qué moda y qué gusto indumentario les definían. Igualmente, trataremos de periodizar la evolución de su consumo textil a lo largo del Antiguo Régimen. De este modo, pretendemos indagar las apariencias de los que satisfacían la demanda de atuendos de moda en la Villa y Corte de Madrid.

PALABRAS CLAVE: Vestido, Sastre, Roperos de Nuevo, Apariencias, Madrid.

ABSTRACT: How wore the tailors? What was the textile identity for the newclothier merchants' guild? These simple questions correspond to everyday aspects for the members of the textile sector, which are still unknown today. Considering that they formed the professional group responsible for the elaboration of the dresses and, therefore, the diffusion of new fashion patterns, it is interesting to know what shared or used. In order to resolve these issues, we will rely on the sartorial image that characterized them as professional and social group. With the references of the Historical Archive of the Madrid, we try to find out what fashion and sartorial taste what defined them. Also, we aim to periodize the evolution of their textile consumption at the

\footnotetext{
${ }^{1}$ Una primera versión de este trabajo fue presentada en la sesión 16 con el título "Familias y consumo en Europa entre 1600 y 1850 . Interiores domésticos y apariencias exteriores" durante el XI Congreso de la Asociación de Demografía Histórica.
} 
end of the Ancient Regime. So we try to resolve the appearances of this sector that satisficing of fashion in Madrid.

KEY-WORDS: Dress, Tailors, Textile Sector, Appearances, Madrid, Ancien Regime.

¿Cómo vestían los sastres? ¿Cuál era la identidad indumentaria de los mercaderes de ropería de nuevo? Estas sencillas preguntas corresponden a aspectos cotidianos de los miembros del sector textil, que aún se desconocen en la actualidad. En el ámbito de la historiografía pocos son los trabajos dedicados a la labor de estos protagonistas del sector textil ${ }^{2}$. Así, con este estudio pretendemos centrarnos sobre su imagen exterior para desentrañar una faceta desconocida de su vida y responder a dichos interrogantes.

Con este fin, nos vamos a servir de la indumentaria como elemento de caracterización de este grupo profesional que se encargaba de la elaboración de vestidos. De hecho, los roperos se ocupaban, al igual que los sastres, de los nuevos patrones indumentarios y su difusión. ¿Pero realmente vestían los modelos vestimentarios que comercializaban? Por eso se hace necesario conocer hasta qué punto los compartían y utilizaban. Algunos estudios les señalan como los responsables del fenómeno de los petimetres, sin embargo se pueden averiguar algunas primeras señales de esta tendencia en sus atuendos, al ser ellos mismos unos petimetres ${ }^{3}$. ¿Podemos aventurar que esta valoración cultural encontró su expresión en los miembros del sector textil?

Éstas son algunas de las cuestiones que pretendemos abordar en este trabajo, donde estudiaremos el vestido como apariencia dentro del más amplio gremio textil en el Madrid del siglo XVIII. La indumentaria era una importante herramienta en la cultura de las apariencias sociales, durante el Antiguo Régimen ${ }^{4}$. Su función ya no era la de proteger de los agentes atmosféricos sino más bien la de diferenciarse y sobresalir ya

2 J.C. ZOFÍO LLORENTE (2005). Gremios y artesanos en Madrid, 1550-1650. La sociedad del trabajo en una ciudad cortesana preindustrial. Madrid: CSIC; R. DE LA PUERTA ESCRIBANO (1997). Historia del gremio de sastres y modistas de Valencia: del siglo XIII al siglo XX. Valencia: Ayuntamiento de Valencia; J.A. NIETO SÁNCHEZ (1995). "Labour, capital and the structure of Textil Industry in XVIIIth Madrid". En Diederiks, H. y Balkeisten, M., Occupational titles and their classification: the case of the textile trade in past times. Max Planck-Institut für Geschichte: Göttingen, pp. 217-229.

${ }^{3}$ C. MARTÍN GAITE (1995). Usos amorosos del Dieciocho en España. Madrid: Anagrama.

${ }^{4}$ D. ROCHE (2004). La culture des apparences: une histoire des vetement (XVIIe-XVIIIe siècles). Paris: Fayard. 
que el actor social moderno exteriorizaba su identidad a través de las apariencias vestimentarias $^{5}$.

De este modo, pretendemos contribuir a su perfil social a través del traje y determinar su identidad como también su imagen. Durante el siglo ilustrado, las apariencias dependían de las modas extranjeras que se convirtieron en seña y distinción cultural. Pocos, de hecho, han profundizado el papel social de la introducción de prendas extranjeras en la sociedad del Antiguo Régimen ${ }^{6}$. Como tampoco se ha estudiado su valor y estimación económica en la transmisión material de bienes ${ }^{7}$. Siguiendo el ejemplo de estos investigadores, vamos a recurrir a las fuentes escritas para abordar a este grupo textil. Entre las escrituras notariales del Archivo Histórico de Protocolo, se priorizarán las testamentarías y en especial: los inventarios de bienes así como las cuentas y partición de bienes que se realizaba a la muerte de los miembros de este conjunto social ${ }^{8}$.

Por eso pretendemos observar a los miembros del grupo textil a partir de su vestido y comprobar qué moda y qué gusto indumentario les definían. Igualmente, trataremos de periodizar la evolución de su consumo textil a lo largo del Antiguo Régimen. También pretendemos indagar las apariencias de los que satisfacían la demanda de atuendos de moda en la Villa y Corte de Madrid. De este modo, presentamos un artículo cuyo objetivo es definir este sector dedicado a la ropa y su casi invisible apariencia indumentaria.

\section{ESTADO DE LA CUESTIÓN}

Desde que la historia se ocupa de la vida cotidiana, numerosos han sido los estudios que se han inspirado en los vestigios materiales. Centradas en cuestiones culturales,

${ }^{5}$ R. MARURI VILLANUEVA (1990). La burguesia mercantil santanderina, 1700-1850: cambio social y de mentalidad. Santander: Asamblea Regional.

${ }^{6}$ J.M. BARTOLOMÉ BARTOLOMÉ y M. GARCÍA FERNÁNDEZ (2011). "Patrimonios urbanos, patrimonios burgueses: herencias tangibles y transmisiones inmateriales en la Castilla interior”. Studia Histórica. Historia Moderna, 33, pp. 29-60.

7 M. GARCÍA FERNÁNDEZ (2013). "Cultura material, consumo, moda e identidades sociales: la almoneda de bienes". En Bartolomé Bartolomé, J.M. y García Fernández, M. Apariencias contrastadas: contraste de apariencias. Cultura material y consumos de Antiguo Régimen. León: Servicio de Publicaciones, pp. 43-64.

${ }^{8}$ M. GARCÍA FERNÁNDEZ (1998). "Herencias y particiones de bienes en Valladolid durante el siglo XVIII: Testamentos e inventarios post-mortem". Investigaciones Históricas: Época moderna y contemporánea, 8 , pp. 73-108. 
estas investigaciones se apoyan en un exhaustivo análisis de las conductas de la sociedad para "apreciar la capacidad del consumo individual y de toda la familia y la subsiguiente demanda diferenciada de géneros textiles y de otros enseres del interior de sus casas - relacionados a su vez con el grado de urbanización, las características del mercado, el estrato social de procedencia o deseado la apariencia externa, la promoción o el precio de los tejidos extranacionales"9. De hecho, estos cambios ponían el acento sobre sus emblemas distintivos y sus ideologías con el fin de definir las nuevas identidades sociales dentro del marco de nuevos ascensos personales y las modificaciones en las pautas de consumo que producirán una nueva movilidad y nuevos hábitos de lucimientos.

Si bien estos trabajos proceden sobre todo del ámbito de la cuestión de género, estos estudios se han trasladado también a otros campos de las Ciencias Sociales en los cuales se han exasperado y contrapuesto los escenarios urbano-rurales. La polarización de estas circunstancias se ha trasmitido hasta en tiempos recientes y se puede apreciar en las publicaciones de Gloria Franco Rubio quien analiza los nuevos cambios a la luz de las nuevas prácticas sociales, repercutiendo en la sociabilidad de la vida doméstica ${ }^{10}$. Siempre dentro del marco histórico-social, Máximo García Fernández estudia los hábitos culturales a esta época de mudanzas que se vivía a las postrimerías del siglo XVIII ${ }^{11}$. Más focalizado en la controversia gremial resulta su reciente publicación Gremios y pleitos. Comportamientos sociales y laborales restrictivos en la castilla interior de los siglos XVI-XVIII donde estudia los pleitos interpuestos por los gremios manufactureros de la Castilla moderna ${ }^{12}$.

Del mismo modo, también José A. Nieto ha dedicado varios trabajos al mundo gremial durante la Edad Moderna. En concreto se trata de estudios dedicados al mundo manufacturero del siglo XVI al XIX. Partiendo de la historia social, se ha centrado en

\footnotetext{
${ }^{9}$ M. GARCÍA FERNÁNDEZ (dir.) (2013). Cultura material y vida cotidiana: escenarios. Madrid: Silex, p. 9.

10 G. FRANCO RUBIO (2001). La vida cotidiana en tiempos de Carlos III. Ediciones libertarias: Madrid; G. FRANCO RUBIO y Ma A. PÉREZ SAMPER (2012). "Mirar la historia con otros ojos", Revista de Historia Moderna, 30, pp. 11-15.

${ }^{11}$ M. GARCÍA FERNÁNDEZ (2012). "Consumo e identidad cultural urbana europea en el largo periodo de transición hacia la contemporaneidad", Revista de historiografía (RevHisto), 16, pp. 129-140.

12 M. GARCÍA FERNÁNDEZ (2016). "Gremios y pleitos. Comportamientos sociales y laborales restrictivos en la castilla interior de los siglos XVI-XVIII", ERASMO: Revista de Historia Bajomedieval y Moderna, 3, pp. 39-54.
} 
el mundo del trabajo artesanal ${ }^{13}$. En este mismo contexto historiográfico, se sitúa el trabajo de John Benson y Laura Ugolini dedicado a los tenderos ingleses donde se exploran los comportamientos de venta al por menor dentro del histórico proceso del trabajo ${ }^{14}$. Basado en una profunda investigación académica, este estudio subraya el papel fundamental desempeñado por el material y su impacto en el balance del comercio de bienes de lujo; como su venta en las primeras galerías comerciales. En especial modo, Ugolini ahonda también en las nuevas revistas de moda donde se explota la variable del consumo que desemboca en una nueva imagen hedonística del hombre de la época Victoriana y Eduardiana. Análogo puede parecer el estudio editado por Bruno Blonde que se centra en los circuitos de venta y consumo ${ }^{15}$. Con un enfoque basado en la historia urbana y social, este libro se completa de estudios culturales con el fin de describir los comportamientos de ostentación que se inscribían en la correlación social como de género en la Europa del tardo medioevo y de la época moderna.

Desarrollado en la Nápoles española, Il lusso cattivo. Dinamiche del consumo nella Napoli del Settecento se centra en esta capital donde los bienes de lujo se utilizan como muestra de distinción y estatus ${ }^{16}$. Alida Clemente analiza esta dinámica social de la ostentación que pronto se confundirá con la siempre más importante difusión de nuevas modas extranjeras. Basado en fuentes literarias y en documentos procedentes de archivos, este libro trata de desentrañar la identidad de esta ciudad, no solo a través de las tiendas sino también de las primeras publicidad en prensa.

Finalmente, en el campo de la Historia del Arte, se debe mencionar a Carolyn Sargentson quien, apoyándose tanto en obras artísticas como en el análisis documental, profundizó los aspectos -no solo estéticos- de los camiseros como una categoría socio-

${ }^{13}$ V. LÓPEZ BARAHONA y J.A. NIETO SÁNCHEZ (2010). "La formación de un mercado de trabajo: las industriasdel vestido en el Madrid de la Edad Moderna", Sociología del trabajo, 68, pp. 147-168.

14 J. BENSON y L. UGOLINI (2003). A Nation of Shopkeepers: Five Centuries of British Retailing. Londres: EH.NET.

${ }^{15}$ B. BLONDE (ed.) (2006). Buyers and Sellers: retail circuits and practices in medieval and early modern Europe: Brepols.

${ }^{16}$ A. CLEMENTE (2011). Il lusso cattivo. Dinamiche del consume nella Napoli del Settecento, Roma: Carracci Editori. 
profesional ${ }^{17}$. Gracias a un enfoque historiográfico, Sargetson estudia a las instituciones, a las colecciones donde la evolución del gusto constituye la base de la producción y difusión de las modas y de las artes decorativas del siglo XVIII.

\section{MADRID: UNA CIUDAD DE MODAS}

Desde que la Corona española decidió implantar la Corte en la Villa de Madrid, el gremio de sastres se convirtió en uno de los grupos profesionales más numerosos de la $V^{V} i l l a{ }^{18}$. No se debía sólo al "efecto corte" ${ }^{19}$ que prometía "dignidades, oficios, pensiones y mercedes que atraían a miles de pretendientes guiados por la codicia de medrar" ${ }^{20}$ sino por la creciente demanda de bienes textiles:

$\mathrm{Si}$ se considera que consume y emplea muchos texidos ordinarios de nuestras fábricas; que mantiene de 4.000 personas de ambos sexos dentro de la Corte, que ocupadas en coser las ropas de su comercio, proveen honradamente a su subsistencia; y que el público se halla surtido en el instante que lo necesita, de vestuario decente, ya sea a dinero contado, o ya fiado, pagándolo con comodidad y lentamente. Este beneficio no se limita a los vecinos de Madrid, sino que también a los pueblos de sus contornos hasta 20 o 30 leguas $^{21}$.

No se puede negar que este fue el periodo de mayor esplendor económico de los sastres y mercaderes quienes debían satisfacer las exigencias indumentarias de los habitantes del Alcázar.

Sin embargo, gran parte de esta demanda fue absorbida también por un pequeño grupo formado por sastres roperos de nuevo. Su trayectoria es paralela a la de la Corte en la capital ya que en 1630 quienes se agremiaron y adquirieron el nombre de

17 C. SARGENTSON (1996). Merchants and Luxury Markets The Marchands Merciers of Eighteenth-Century Paris. Londres: Victoria and Albert Museum Studies in the History of Art and Design Victoria and Albert Museum Editions.

18 J. NIETO y J.C. ZOFIO (2015). "Los gremios de Madrid durante la Edad Moderna: una revisión”. AREAS, Revista Internacional de Ciencias Sociales, 34, pp. 47-61.

${ }^{19}$ V. PINTO CRESPO (2001). Madrid: Atlas históricos. Madrid: Fundación CajaMadrid.

20 Á. ÁLVAREZ-OSORIO (2006). "La esfera de la corte: príncipe, nobleza y mudanza en la jerarquía”. En Chacón Jiménez, F. y Monteiro, N. (eds.), Poder y movilidad social. Cortesanos, religiosos y oligarquías en la península ibérica (siglos XV-XIX). Madrid: CSIC, pp. 146.

${ }^{21}$ E. LARRUGA (1787). Memorias políticas y económicas sobre los frutos, comercio, fábrica y minas de España. Madrid: Imprenta de Benito Cano, p. 342. 
mercaderes de ropería de nuevo. Como se recalcaba en las ordenanzas, se caracterizaban por una doble naturaleza: la comercial y la artesana que les diferenciaba de los sastres -sobre todo a partir de $1657^{22}$. Los roperos de nuevo, de hecho, se distinguían por una rápida producción de ropa hecha.

Este rasgo característico se destacaba también en su estatuto donde el primer requisito fundamental era que "todos los maestros de este gremio que tuvieran tiendas de nuevo en esta Corte y Villa" ${ }^{23}$. En efecto, los roperos de nuevo estaban especializados en abastecer al gran público de ropa hecha. Y para hacer esto, debían estar surtidos de numerosas piezas iguales. Con esta estandarización de las prendas no solo se marginaban a los sastres y su confección a medida sino que se establecía el primer sistema de tallaje. De hecho, mientras que los primeros inventarios de finales del siglo XVII diferenciaban entre "tallas grandes" y "tallas pequeñas", los del siglo se medían en "de a cuatro varas", "de tres varas y tercia", "de cuatro varas y media", "de cuatro varas y cuarto", etc.

En este proceso de fabricación de prendas listas para vestir, los roperos de nuevo se adelantaban a los clientes, comprando las telas directamente a los mercaderes y abaratando así los costes. Bastaba con comprobarlo en las palabras de Suárez de Figueroa quien argumentaba acerca de esta reducción de los precios:

Venden los vestidos a menor precio de lo que salen hechos en casa", puesto que compran "en las partes donde los mismos mercaderes, todo cuanto interviene en las obras, como paños, sedas, aforros, pasamanos y cosas así. De forma que, reduciéndose todas las ganancias a una, y no teniendo particular cuenta y razón, pueden hacer cualquier conveniencia. Mas la utilidad más considerable viene a ser, ahorrar el que se viste en sus tiendas los crecidos aprovechamientos de los sastres, que por este camino los pierden sin algún remedio ${ }^{24}$.

Este abaratamiento de costes se conseguía gracias a que los roperos se anticipaban

\footnotetext{
22 J.A. NIETO SÁNCHEZ (2006). Artesanos y mercaderes: una historia social y económica de Madrid, 1450-1850. Madrid: Fundamentos.

23 V. LÓPEZ BARAHONA y J.A. NIETO SÁNCHEZ (2011). "La ropa estandarizada. Innovaciones en la producción, comercio y consumo de vestuario en el Madrid del siglo XVII". Sociología del Trabajo, 71, pp. 118-136.

${ }^{24}$ C. SUÁREZ FIGUEROA (1615). Plaza Universal de todas las ciencias, Madrid: Luis Sánchez, p. 361.
} 
a los gastos y gustos de los clientes que se identificaban con la nueva clase urbana, por lo que requerían de apariencias cortesanas y a la moda. Entre ellos, no solo se hallaba "la gente pobre y trabajadores" -como declaraban los sastres ${ }^{25}$-, sino destacaban también los criados del Alcázar o los miembros de baja nobleza como los de la clase administrativa. $\mathrm{Y}$ gracias a estos contactos, se enriquecieron, ya que les proporcionaron un estilo de vida holgado e importantes capitales de bienes. Basta con analizar los inventarios de sus casas que estaban ricamente amuebladas con diferentes piezas de maderas -como espejos, escaparates, sillas, y escritorios- y el contenido de sus guardarropas a la moda.

\section{EL GUARDARROPA DE LOS SASTRES}

La creación del gremio de roperos de nuevo ocasionó un debilitamiento del comercio de los sastres que se vieron afectados por el nuevo sistema de confección estandarizada. El sastre, de hecho, era aquel oficial que cortaba y cosía vestidos, tal y como se puede apreciar en el famoso cuadro de Giovan Battista Moroni: The Taylor donde su dignidad residía en las herramientas de su trabajo: las tijeras. Ostentando con orgullo su oficio, el joven vestía según la moda española -que se componía de ropilla, calzones y tahalí para la espada- al igual que los nobles de la primera modernidad europea.

Sin embargo, Torres de Villarroel comentaba en sus Visiones que también en el siglo XVIII, los sastres se caracterizaban por prendas a la moda y de colores reservados a la aristocracia:

Lo que yo puedo decirte, porque lo que sabe todo el mundo es que ciertísimo que nunca fue más feliz la Corte que en este siglo; tanto que para quitar los escandalosos desordenes de su soberbia, poder y suntuosidad, se halló precisado el sabio y temido monarca que hoy nos gobierna a arrojar de Madrid, plata, el oro, los coches, las telas, los encajes y las piedras por pragmáticas expedida cuatro años ha. Las rastreras y meloneras vestían los finísimos bordados que en tu tiempo se fabricaban para el culto de templos e imágenes. En tu edad todos andabais vestidos de réquiem; no

\footnotetext{
${ }^{25}$ Archivo Histórico Nacional (A.H.N.), Consejos, Legajo 490, enmienda capítulo X.
} 
conocisteis la púrpura si no es en las personas reales, y yo la he visto en zapateros y sastres ${ }^{26}$.

¿Qué nos quiere decir este pensador con esta invectiva? ¿Que los sastres adoptaron el vestido a la francesa?

Este atuendo que se difundió también con el nombre de vestido a lo militar - en honor a Luis XIV, quien elevó sus prendas características en prerrogativa palaciegase componía de casaca, chupa y calzón. A pesar de haberse introducido durante el gobierno de Juan José de Austria, se generalizó en la Villa con la llegada al trono de Felipe V también gracias a la labor de los sastres ${ }^{27}$. Primero ante todo, fue el sastre de $\mathrm{Su}$ Majestad quien propició el uso de este nuevo atuendo, provocando que el nuevo monarca no acudiera a la capilla vestido a la española puesto que "no había ningún vestido en buen estado" 28 . Este subterfugio de los criados franceses obligó al abandono paulatino de la golilla y la abolición del sastre de golilla en 1707.

Pero también los documentos notariales de la época, nos revelan que los sastres confeccionaban este nuevo traje en detrimento del español. No solo lo confeccionaban para los soldados o cortesanos borbónicos, sino que también se empezaban a adoptar en la vida cotidiana ${ }^{29}$. El expurgo de todas las escrituras notariales apunta a este cambio en los hábitos indumentarios. Se trata de más de 20 protocolos dedicados a los sastres donde se ha evidenciado que este atuendo formaba parte de sus guardarropas, como se evidencia en el gráfico 1 . Con 55 referencias de vestidos compeltos inventariados y tasados comprendido entre 1701-1789, se ha podido averiguar que las prendas de origen francés eran piezas fundamentales del atuendo diario de estos oficiales en comparación a las de origen español que apenas se contabilizan. La influencia gala se

${ }^{26}$ D. TORRES DE VILLARROEL (1821). Sueños morales, visiones y visitas de Torres con Don Francisco de Quevedo, por Madrid, Madrid: Librería de Ramos, p. 144.

${ }^{27}$ A. DESCALZO LORENZO y C. GÓMEZ-CENTURIÓN (1998). "El Real guardarropa y la introducción de la moda francesa en la Corte de Felipe V”. En Gómez-Centurión, C. y Sánchez Belén, J. A. (eds.), La herencia de Borgoña: la hacienda de las reales Casas durante el reinado de Felipe $V$. Madrid: Centro de Estudios Políticos y Constitucionales, pp. 157-187.

${ }^{28}$ A. DESCALZO LORENZO y C. GÓMEZ-CENTURIÓN (1998). "El Real guardarropa y la introducción de la moda francesa en la Corte de Felipe V”. En Gómez-Centurión, C. y Sánchez Belén, J. A. (eds.), La herencia de Borgoña: la hacienda de las reales Casas durante el reinado de Felipe $V$. Madrid: Centro de Estudios Políticos y Constitucionales, pp. 157-187.

${ }^{29}$ A. GIORGI (2014). "La difusión del vestido francés en la villa de Madrid durante la segunda mitad del siglo XVIII”. En CHACÓN JIMÉNEZ, F. y GARCÍA FERNÁNDEZ, M. Ciudadanos y Familias. Individuos e identidad sociocultural hispana (siglo XVII-XIX). Valladolid: Instituto de Simancas - Universidad de Valladolid, pp. 411-422. 
mostraba netamente superior frente a la castiza que, solo a principios del siglo XVIII, alcanzó su máxima presencia.

GRÁFICO 1: Comparación de prendas españolas y francesas en los guardarropas de los sastres (1701-1789)

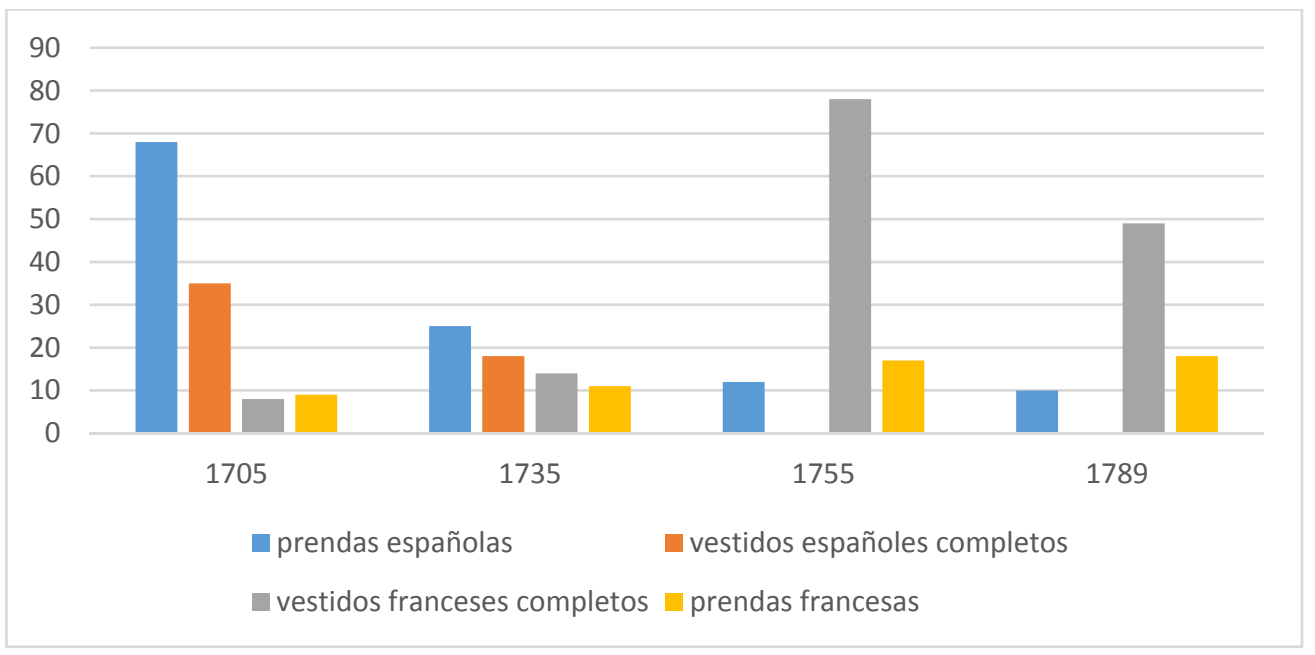

Fuentes: AHPM, protocolos varios. Elaboración de la autora

Tenemos que reconocer que el vestido de ropilla y calzón cayó en desuso con la subida al trono de Felipe V pero la capa seguía presente como prenda de abrigo. Muestra de ello, es el Inventario de bienes de José Tiedra, maestro sastre de la villa quien falleció en $1743^{30}$. Redactado por su mujer -Rafaela González- este documento sin valoración económica recalca la predominancia de esta nueva moda francesa frente a la española donde hallamos un capote oscuro y una patria capa española. A pesar de no indicar el valor, su guardarropa se jactaba de ricas prendas galas. Entre éstas, destacaban sobre todo los dos vestidos de terciopelo completos de sus accesorios y las tres casacas. Esta prenda superior se podía combinar con las cuatro chupas y el calzón de color oscuro.

Menos abundante era, en cambio, el Capital de bienes de Francisco Javier Duque ${ }^{31}$. Realizado en 1746, este documento solo se componía de tres artículos; aun así, eran de un gran valor económico: el primer vestido era el más suntuoso ya que se tasaba en 600 reales; el segundo era un conjunto de dos piezas que se componía de una casaca y

\footnotetext{
${ }^{30}$ Archivo Histórico de Protocolos de Madrid (en adelante A.H.P.M.), Prot. 14949, s.f.

${ }^{31}$ AHPM, Prot. 14960, f. 1.
} 
calzón valorados en 200 reales y por ultimo otro conjunto igual otra de color negro por el valor de 120. A pesar de no estar descritas con minuciosidad, estas piezas delataban su riqueza a través de la tasación económica. Por ejemplo, el primer traje de Francisco Javier podía ser uno de los que causaron las feroces críticas de Torres de Villarroel hacia la faceta más vanidosa de los sastres.

Pero, ¿podemos decir que este era un comportamiento indumentario propio de los sastres del siglo XVIII?

\section{LA IMAGEN DE LOS ROPEROS DE NUEVO}

Si bien los sastres vestían según los cánones imperantes de la moda francesa, los roperos apenas habían adoptado este atuendo de principios de siglo XVIII (gráfico 2). Tal y como se comprueba en el Inventario de bienes que el mercader de ropa de la Calle Mayor, Juan Andrade Sanz realizaba en $1703^{32}$. Este documento cuenta con varias piezas indumentarias y sólo dos prendas de origen francés. En concreto, entre los numerosos vestidos a la moda filipina y las ropillas, solo hallamos tres casacas y dos chupas. Si las casacas estaban confeccionadas en felpa o tafetán oscuro, las chupas eran de raso color de fuego, con flores bordadas. Más curioso resultaba el caso de Andrés Donoso de quien se inventariaban los bienes a su muerte en $1707^{33}$. En el rico apartado dedicado a las piezas de su tienda se pueden apreciar estas dos prendas a pesar de que solo piezas españolas formaban parte de su guardarropa particular, compuesto por dos capas, un coleto, un par de mangas, una capa y dos libreas españolas. Pero hay que subrayar que no todos los roperos se resistían a la moda cortesana. La Batalla de Almansa con el consiguiente asentamiento del reinado de Felipe V, de hecho, determinó el auge de este atuendo que se filtró en la industria textil. Durante la primera mitad de la centuria, la moda francesa se había difundido y se confirmaba como la imagen de estos comerciantes.

Si a principios de 1700 , los vestidos a la española constituían el núcleo de los armarios de estos comerciantes, paulatinamente se fueron poblado de un siempre mayor número de vestidos y prendas francesas. Como se puede apreciar en el gráfico 2 , se observó un paulatino incremento de vestidos y prendas francesas en detrimento de los españoles, en este gremio.

\footnotetext{
${ }^{32}$ AHPM; Prot. 11306, f. 479.

${ }^{33}$ AHPM; Prot. 13187, f. 1153.
} 
GRÁFICO 2: Comparación de prendas españolas y francesas en los documentos notariales.

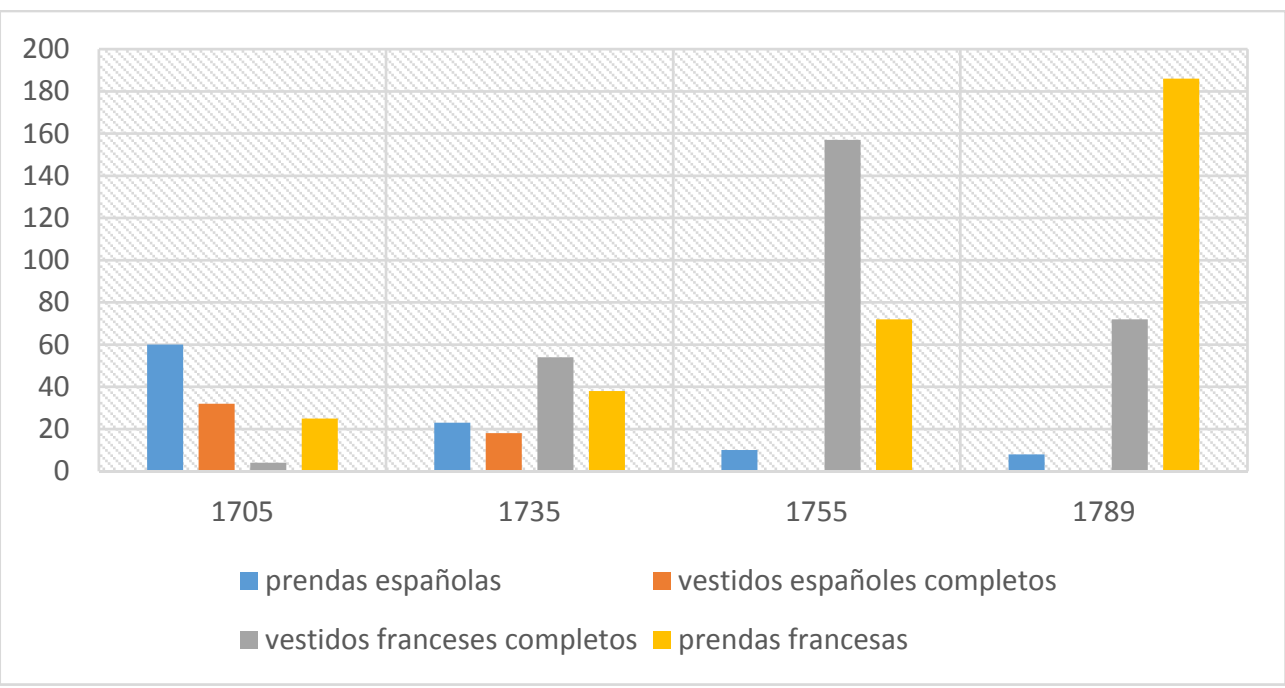

Fuentes: AHPM, protocolos varios. Elaboración de la autora

En concreto, el pico se verificó a mediados de siglo, cuando los vestidos cortesanos completos de sus accesorios remplazaron totalmente los españoles. Sólo se resistían las capas como prendas de abrigos autóctonas frente a las primeras incidencias de prendas foráneas que se difundían bajo las influencias imperialistas inglesas y francesas. Muestra de ello, es el Capital de bienes de $D^{a}$ María de la Cruz Valero para D. Pedro Calisto Honorato Bruno, en el cual se le entregaban prendas de procedencias extranjeras $^{34}$. A excepción de una única capa de paño de color plomo con vueltas de terciopelo que se valoraba en 200 reales, su armario destacaba por un capingot ya andado que era un sobretodo con una media capucha abierta -que se introdujo en España durante los años cuarenta. Por el resto, este inventario se componía de vestidos completos, entre los que destacaba sobre todo uno de "paño fino color de aceituna casi nuevo y dos pares de calzones en quinientos reales". Esta suntuosidad se apreciaba también en los restantes trajes, compuestos por casaca, chupa y calzón -todos nuevos. Valorados en no menos de 360 reales, estos atuendos se distinguían por su colorido azul y flor de romero- frente a las restantes piezas oscuras.

Esta tendencia hacia lo francés se incrementaba hacia finales de siglo cuando se

\footnotetext{
${ }^{34}$ AHPM, Prot. 19416, f. 1. Las siguientes citas, salvo que se indique lo contrario, proceden de dicho documento del cual obviamos repetir la referencia.
} 
asistía a un aumento de estas prendas en este gremio. El capital de bienes de Casimiro Pablo Fernández, delataba esta propensión ${ }^{35}$. En efecto, solo se han podido hallar tres capas españolas en este documento formado sólo por prendas de procedencia foránea y en concreto francesas. En este sobresalía la presencia de un cabriolé o sea una capa con aberturas laterales que se vestía para los paseos en coche ${ }^{36}$. Esta era de paño de color azul, ya usada por lo que se tasaba en apenas 30 reales. En efecto, como mercader de ropa nueva en los soportales de la Calle Toledo lucía los géneros que vendía, como este abrigo que se difundió con anterioridad a la década de los setenta. El resto de su guardarropa se componía de prendas francesas, entre las que hallamos tres casacas tasadas 40 reales cada una- cuatro calzones -todos usados y valorados en unos 50 reales en total. También destacaban los tres vestidos completos, de los cuales el más preciado era el de "paño verdoso que se compone de casaca, chupa y calzón con botones de similor, tasado en 289 reales". Sin embargo, hay que subrayar la importante presencia de prendas semi-interiores. Las chupas, los chalecos y los chupetines superaban las 13 unidades siendo las chupas, las que predominaban entre sus bienes. Con 10 ejemplares, éstas eran también las más preciadas, siendo la más valiosa "una chupa de paño aplomad suelta a medio andar en setenta y cinco"

A pesar de ser bastante menos suntuoso, el inventario y Tasación de María Fernández, viuda de Domingo Arnaez ${ }^{37}$. Mercader de ropa nueva y dueño de una casa de morada en el Portal de Paños de Puerta de Toledo, Domingo encarnaba el perfil del ropero de final de siglo. Su guardarropa, de hecho, se componía de algunas prendas francesas -en concreto, tres casacas, 2 calzones y "una casaca, chupa de carro de oro con botón de ylo de lo mismo, en 90 reales". De este modo, su armario reflejaba la composición del grafico 2 donde se contabilizaba sólo una capa española frente a las prendas francesas y ningún vestido completo.

\section{A MODO DE CONCLUSIÓN.}

La cultura de las apariencias introducida en España con la subida al trono de los Borbones produjo el moderno discurso de las apariencias del cual el vestido era esencia

\footnotetext{
35 AHPM, Prot. 17394, f. 180. Las siguientes citas, salvo que se indique lo contrario, proceden de dicho documento del cual obviamos repetir la referencia.

36 M. TEJEDA FERNÁNDEZ (2007). Glosario de términos de la indumentaria regia cortesana. Málaga: Universidad de Málaga.

${ }^{37}$ AHPM, Prot. 20563, f. 1. Las siguientes citas, salvo que se indique lo contrario, proceden de dicho documento del cual obviamos repetir la referencia.
} 
por su significado y valor de identidad y poder ${ }^{38}$. Esta praxis del Antiguo Régimen plasmaba la identidad a través de las apariencias, no solo de los miembros del Alcázar sino también de los que abastecían la Casa Real. En este sentido, el predominio de estas apariencias se difundía a través de esta estética de prestigio social y personal que subrayaba el vínculo con la corte. De esta relación se sirvieron los sastres y roperos, autores de los primeros trajes militares en la Villa de Madrid. Éste era testimonio de la conducta palaciega y proyectaba honor a través de sus apariencias, tal y como ha quedado patente mediante el análisis de los documentos notariales.

Dentro de los estudios dedicados a la identidad de estos artesanos y su papel en las postrimerías del Antiguo Régimen, se ha tratado de reconstruir su imagen indumentaria ${ }^{39}$. En efecto, estos miembros de la industria textil de la época no sólo fueron los creadores de estas apariencias sino que se convirtieron en un importante vehículo de difusión. Los sastres y los roperos de nuevos fueron los agentes de esta difusión de modas y prendas extranjeras. En especial modo, se ha observado que los sastres adoptaron el vestido cortesano mientras que los roperos de nuevo lo convirtieron en su imagen. Eso se debía a que los primeros vistieron el vestido cortesano, a pesar de ser mucho más mayor la presencia de prendas y atuendos de carácter castizo. Los segundos, en cambio, impusieron un sistema de estandarización de la ropa y de su tallaje, lo que les permitió abaratar los costes y difundirla en la sociedad. De hecho, ellos fueron los primeros en vestir los productos de este nuevo sistema. Las escrituras notariales han relevado que su conducta vestimentaria se apoyaba en estas apariencias foráneas. Tal y como se ha analizado, tanto los vestidos como las prendas francesas se convirtieron en imagen de su identidad social. Sobre todo se definieron por la adopción de las nuevas prendas de abrigas que procedían del extranjero, como el capingot y el cabriolé.

La sistematización de estas imágenes indumentarias subrayaba el valor de las apariencias del Madrid ilustrado al tiempo que evocaba y exhibía una nueva identidad estamental.

\footnotetext{
${ }^{38}$ M. FOUCAULT (1996). Les mots et les choses. Une archéologie de sciences humaines. París: Gallimard.

${ }^{39}$ D. MÚÑ̃Z NAVARRO (2011). Comprar, vender y consumir: nuevas aportaciones a la historia de consumo en España. Valencia: Universidad de Valencia.
} 


\title{
VESTIDOS POBRES: CONSUMOS ESTANCADOS. VALLADOLID EN EL SIGLO XVIII
}

\section{POOR DRESS: STAGNATING CONSUMPTION. VALLADOLID IN THE EIGHTEENTH CENTURY}

\author{
MÁXIMO GARCÍA FERNÁNDEZ • \\ Universidad de Valladolid - IUHS \\ mgarcia@fyl.uva.es
}

Recibido: $12 / 09 / 2016$

Aceptado: 23/11/2016

RESUMEN: Miseria, no reposición y escasez caracterizaban las pobres formas de vestir de enfermos de toda condición, ratificadas en el asiduo recurso al legado textil por parte de campesinos y agremiados... aunque el regalo de trajes nuevos en el momento nupcial también informe sobre una tendencia al incremento de la demanda popular, cuando la evolución hacia una nueva estética mejor surtida cada vez parecía más generalizada. ¿Únicamente la riqueza definía los comportamientos vestimentarios?

Los pobres ropajes de la vestidura popular diaria muestran la evolución de las principales esferas de lo cotidiano, a partir de la cultura material, el consumo y la apariencia externa en clave social, tras la conversión del vestido en imagen de civilización y ya no un mero objeto de uso. La comparación de los ajuares portados por los enfermos del Hospital de la Resurrección de Valladolid, además de las transmisiones hereditarias de ropas legadas a muchos beneficiarios cercanos, en contraste con los rasgos del vestir masculino y femenino presentes en las grandes ciudades y en la Corte, ofrecen tanto la evolución de las enormes y generalizadas carencias populares como los deseos urbanos de lucimiento; otro símbolo de modernización a través del atavío externo frente a una indigencia desharrapada. Sus cantidades, calidades y usos eran reconocibles como apariencia dominante en la Castilla del siglo XVIII.

PALABRAS CLAVE: Consumo; Vestido; Castilla; siglo XVIII.

ABSTRACT: Wretchedness and shortages characterized the poor forms of the dress of sick, ratified in the regular recourse to textile legacy. However, the gift of new clothes in the wedding time also report on an increasing trend popular demand, when the

\footnotetext{
- Proyecto investigador financiado: Civilización, juventud y cultura material e inmaterial. Familia e identidad social. Demandas y apariencias en la Castilla interior. 1500-1850; Ministerio de Economía y Competitividad, convocatoria Retos, 2014-2017, HAR2013-48901C6-3-R.
} 
evolution towards a new aesthetic better stocked seemed increasingly widespread. The wealth defined the vestimentary behaviors?

The poor robes of daily popular garment show the evolution of everyday life, from consumption and external appearance in social key, after conversion of the dress on important image of civilization. The grave goods carried by the patients of the Hospital of the Resurrection of Valladolid, in addition to the hereditary transmission of many clothes, in contrast to the features of dress male and female present in cities and in the Court, offer both the evolution of massive and widespread popular urban shortcomings and wishes to show off. Another symbol of modernization as a dominant appearance in the Eighteenth Century Castile?

KEYWORDS: Consumption; Dress; Castile; XVIIIth Century.

Este trabajo se inscribe dentro de los planteamientos metodológicos de nuestro actual proyecto de investigación: apreciar la evolución de las principales esferas de lo cotidiano, a partir de la cultura material, el consumo y la apariencia externa en clave social, tras la conversión del vestido en imagen de civilización y ya no un mero objeto de uso. Los pobres ropajes de la vestidura popular diaria servirán de hilo conductor.

La comparación de los pobres ajuares portados por los enfermos encamados en el Hospital de la Resurrección de Valladolid, además de las transmisiones hereditarias de ropas legadas a muchos beneficiarios cercanos, en contraste con los rasgos sobresalientes del vestir masculino y femenino presentes en algunas grandes ciudades y en la Corte, muestran tanto la evolución de las enormes y generalizadas carencias populares como los deseos urbanos de lucimiento; otro símbolo de modernización a través del atavío externo frente a una indigencia desharrapada. Sus cantidades, calidades y usos eran reconocibles como apariencia dominante en la Castilla del siglo XVIII.

Todo golilla era considerado un antiguo mientras un petimetre sólo podía ser criticado por excesivamente moderno; tópicos a la moda. Los jóvenes consumían vestidos a la francesa completos frente a una típica (castiza) indumentaria maja donde no faltaría la capa: ¿el mantenimiento del traje español originó el motín de Esquilache en 1766? Cuestiones todas de cultura material cotidiana y de civilización en progreso muy alejadas de la precaria realidad popular mayoritaria.

Madrid era escenario del debate internacional sobre las apariencias. Allí la batalla indumentaria fue ganada por las modas francesas: lazo y corbata para militares y políticos, mientras presentarse vestido de ropilla y golilla significaba blasonar de mal 
vasallo. Pero muy poco se atiende a la mayoría de los harapos circundantes, aunque el padre Feijoo resumiese así su visión de la cotidianeidad: "cuatro trapos cubren sus carnes; o mejor diré que por las muchas roturas que tienen las descubren"1.

\section{CONVENIENCIAS ESTÉTICAS O NECESIDADES PERENTORIAS: CONTRASTES DE APARIENCIAS}

Entre 1750 y 1800 el vestido cortesano se había convertido ya en atuendo urbano predominante y nuevo código de civilización. A finales del siglo XVIII los comportamientos eran más multiformes: prendas extranjeras junto a demandas populares adaptadas a la tijera del sastre. Hábito cortesano desde 1730, una paulatina filtración afrancesada sustituiría al oscuro modelo hispano del XVI (únicamente un $22 \%$ de sus ropajes se inventariaban ya al uso español). Procedente del uniforme militar, se convirtió en indicador social: casacas y chupas internacionales frente a capas y golillas patrias. Los aledaños de palacio eran escenario material de aquel ritual ceremonial, extendiéndose hacia abajo. Triunfo de dicha indumentaria completa también entre los menestrales madrileños; aunque la costumbre heredada siguiese pesando muchísimo en las dotes de los jóvenes de la época. En todo caso, adquiridas habitualmente en las tiendas, de diario y hasta bastas junto a otras más suntuosas; como se aprecia en el traspaso de prenderías y comercios de ropa hecha, donde los artesanos y comerciantes de la Plaza Mayor de Madrid vendían los géneros necesarios para cubrir aquella moda popularizada. Aunque no faltasen tampoco capas y jubones, allí sobresalían los vestidos franceses, reduciendo su precio ante su acelerado y gran consumo. Muestran fehacientemente la oferta textil y el cambio de los gustos masculinos, tendentes a la supremacía del traje a la francesa y a las prendas de abrigo foráneas.

¿La apariencia podía minimizar las barreras estamentales entre ciertas familias en ascenso? Esa realidad se refleja también en la extendida polémica sobre los lujos del atuendo femenino. Continuación ilustrada de las clásicas Leyes suntuarias, en el Discurso sobre el lujo de las señoras y proyecto de un traje nacional (fechado en 1788), una mujer proponía el uso de tres tipos de vestidos con el fin de distinguirlas según su estatus: La Española, La Carolina y La Borbonesa o Madrileña ${ }^{2}$. La Junta

${ }^{1}$ B.J. FEIJOO (1739). Teatro crítico universal; tomo 8, discurso 12: 'Honra y provecho de la Agricultura' ('Del estado de los labradores en algunas provincias de España').

${ }^{2}$ Autoría anónima, 1788 (facsímil; Sevilla: Extramuros, 2009). 
de Damas de la Matritense se negó a vigilar su instauración y cumplimiento nivelador ${ }^{3}$, si bien reflejaban un gusto moderno muy diferente a la estética popular predominante.

Antes, en clave social comunitaria de mantenimiento de un estatus de apariencia inmediatamente visible (siempre), Felipe IV prohibiría el uso del guardainfante entre todas las mujeres... salvo para las prostitutas, claramente diferenciadas y marcadas estéticamente de esa manera tan plástica, llamativa y reconocible. Tapadas o velazqueños guardapiés de viejas friendo huevos también como símbolos notorios.

$\mathrm{Y}$ a finales del siglo XVIII, por ejemplo en Ferrol, no eran infrecuentes los impagos de ciertas damas a las modistillas que les habían ataviado con las novedades más de moda entonces (sombreros y otros complementos) para, mediante la demanda de un atrezo mucho más moderno y por emulación entre su círculo social de adscripción, mostrar nítidamente su posición privilegiada (militar) respecto al común del vecindario: debían lucir sus modelos aunque arruinasen a sus familias los encargos demandados ${ }^{4}$. Comparativamente, en otras zonas marítimas de la España mediterránea (Cartagena o Valencia), y a diferencia de lo ocurrido en la Castilla interior -salvo en Madrid-, aquella progresiva globalización de los patrones de consumo, utilizando la propuesta metodológica del vicarious consumers, y en un lento trickle-down, también llegaría a provocar una notable expansión del mercado de no pocos artículos de lujo 5 .

Por el contrario, ¿cuántos pobres callejeros u hospitalizados podían mudarse de ropa?; ninguno. Algunas de nuestras visiones de lo popular proceden de la tradición barroca castellana. Pobres pícaros o hidalgos. Negros hábitos talares y golillas. Oscuras viudas y místicas tocadas ${ }^{6}$. Una imagen que tras el tamiz ilustrado llegó a la recreación de falsos diseños cotidianos y trajes regionales decimonónicos.

\footnotetext{
${ }^{3}$ Respuesta a las objeciones que se han hecho al proyecto de un traje nacional para las damas, 1788.

M. GARCÍA FERNÁNDEZ (2011 -2014-). "La cuestión de un Traje Nacional a finales del siglo XVIII. Demanda, consumo y gestión de la economía familiar". Norba. Revista de Historia, 24, pp. 151-165.

${ }^{4}$ M.R. GARCÍA HURTADO (ed.) (2009). Vivir las Luces. La vida cotidiana en la España del siglo XVIII. Madrid: Sílex.

5 Véanse: M. PÉREZ-GARCÍA (2013). Vicarious Consumers. Trans-national meetings between the West and East in the Mediterranean world (1730-1808). Farnham: Ashgate; o L.M. ROSADO CALATAYUD (2016). "Moda, la sociabilidad y nuevos patrones de consumo en el Reino de Valencia en el siglo XVIII. El caso de la ciudad de Xàtiva”. Estudis. Revista de Historia Moderna, 42, pp. 155-176.

${ }^{6}$ C. BERNIS (2001). El traje y los tipos sociales en El Quijote. Madrid: Visor.
} 
Difícilmente se corresponden con la realidad: representaban contrastes de apariencia y reconocimiento por el porte: "hice dos vestidos de calza entera muy gallardos y otro saqué llano para remudar, al parecerme que quien así me viera [y con un par de criados] fácilmente me reconocería; comencé a pavonear y gastar largo"7, como fórmula picaresca excepcional.

En cuanto a las prendas interiores higiénicas, cuellos y puños, se convirtieron (o no) en escaparates de limpieza o refinamiento (querían que todos supiesen que eran de hilo fino). Se jugaba con las apariencias, pasando ya a ser cuestión de buena educación y decencia... o, con mayor frecuencia, revelando inexistencia o suciedad ${ }^{8}$. Era un lujo contar con prendas de repuesto, cambiarse o lavar a menudo la ropa blanca de cama. Las bragas tardarían en imponerse; incluso en París se consideraba hábito de "actrices y prostitutas". El principal atavío de la lencería íntima popular masculina y femenina seguía siendo la camisa ${ }^{9}$.

Eran mucho más frecuentes las penurias populares, aunque se estuviese en Roma, donde, si bien "el uso ha hecho que sólo triunfe la galantería, el adorno, la moda y la usanza" (criticándose las "vanas apariencias del mundo..., dando al siglo escándalo viviendo a la militar moda"), paralelamente, se apreciaba un extendido roto, sucio, mal equipado y antiguo ropaje de "desaliñados andrajos", compuesto de "sudada redecilla, mugriento pecho de jubón que otrora fue negro y ahora del color de ala de mosca y una camisa en otro tiempo blanca". En suma: "todo en el pobre respiraba melancolía, anunciaba miseria, olía a tiricia y resollaba economías, trayendo cierto olorcillo a cera, revuelto con especies de sepultura"; un traje raído y con "cortos posibles de mejora"10.

\footnotetext{
${ }^{7}$ M. ALEMÁN (1604). Guzmán de Alfarache, $2^{\mathrm{a}}$ parte, libro II y III.

${ }^{8}$ R. SARTI (2003). Vida en familia. Casa, comida y vestido en la Europa Moderna. Barcelona: Crítica, pp. 250-257. Véase: D. ROCHE (1997). Histoire des choses banales. Naissance de la consummation dans les sociétés traditionnelles (XVIIe-XIXe siècles). París: Fayard.

9 "Su ropa contribuye mucho a su singular suciedad; multitud de gentes, incluso las más ricas, no tienen más que una camisa; la ponen nueva y la dejan seis meses sobre el cuerpo hasta que se cae de sucia; es imposible pasar en España ocho días sin piojos"; Anónimo (1765). Estado político, histórico y moral del reino de España, p. 90.

${ }^{10}$ R.M a PÉREZ ESTÉVEZ y R.Ma GONZÁLEZ (1992). Pretendientes y pícaros españoles en Roma. Siglo XVIII. Valladolid: Universidad de Valladolid; El Passeo de Roma, concluido en Nápoles. En Roma, año de 1736 (Manuscrito 95, Biblioteca-Archivo de la Iglesia Nacional Española en Roma), pp. 67-68. Un amigo: “opresor cuellecillo, oscura casaquilla más antigua que las calzas atacadas, angosta capilla llena de pulgas, desperdicios de zapatos con visos de albarcas... y con muchos remiendos y lodos"; otro pobrete: "hambriento de casaca, necesitado de chupa y ayuno de calzones, con carencias de capa".
} 
Lo mismo que las visiones negativas sobre el ropaje nacional apreciadas por los extranjeros. En su recuerdo quedaban suciedades y negritudes, penurias y harapos. Sus -peyorativas- descripciones sobre la cultura material popular castellana escondían malas apariencias bajo un atuendo español ${ }^{11}$. Los contrastes y la falta de calidad comenzaban nada más cruzar la frontera. Todavía durante el siglo XVIII se mostraron muy críticos con la pobreza visualizada y con los contrapuntos apreciados entre vecinos: en el Pirineo "todo da una impresión de salvajismo"12; "los hombres y mujeres del pueblo [en Cataluña] van mal vestidos, sin medias y descalzos; mientras, en Andalucía donde la miseria es más real, parecen exteriormente gozar de más acomodo"13.

No extraña, así, que hacia 1753 se alabase la caridad del obispo vallisoletano don Martín Delgado Cenarro al dedicar sus rentas a repartir "a los muchachos calzones y camisas, y a ellas guardapiés y jubones, para que unos y otras se pusiesen a servir"14.

Vestuarios miserables ${ }^{15}$ :

"un pobre trapo le sirve de toca; en una remendada manta lleva seis criaturas desnudas...; por estar toda rota la camisa, la necesidad le obliga a cercenar las faldas para acudir al cuerpo; los calzones, salpicados de diferentes zurcidos, tiene que volverlos lo de atrás adelante; las mangas de fustán apenas andan asidas a un miserable jubón de gamuza; la ropilla se ha deshecho a puras peticiones de los zaragüelles; la capa también ha entrado en la sisa, de tantos remiendos que se han ofrecido para socorrer la necesidad del vestido; el sombrero, como los zapatos, de tanto limpiarlos ya no tienen color"; maestras de coger puntos a las medias tanto en la pública España barroca como en la posterior

${ }^{11}$ J. GARCÍA MERCADAL (1999). Viajes de Extranjeros por España y Portugal (Desde los tiempos más remotos hasta comienzos del siglo XX). Valladolid: Junta de Castilla y León; seis tomos.

${ }^{12}$ Ibid.; Young (1787). Viaje en España, tomo VI, p. 308.

${ }^{13}$ Ibid.; Peyron (1772). Nuevo Viaje en España y Ensayos sobre España, tomo V, p. 250.

${ }^{14}$ V. PÉREZ (1983). Diario de Valladolid (1720-1784). Valladolid: Grupo Pinciano, p. 293.

${ }^{15}$ F. SANTOS (1663). Día y noche de Madrid, Discursos de lo más notable que en él pasa (edición 2010; discurso II, pp. 656 y 661). "La capa, blanquea con la edad; la valona, poco; la golilla se acuerda de la batalla Naval según muestra su antigüedad...”; Ibid., discurso V, p. 680. 
teóricamente más ilustrada. "Bien conozco que son pobres... [aunque] también hay quien aventaje en trajes a los que pueden más... que, según he oído, un cortador de carne se echa tantas galas y más que un almirante".

\section{LA ROPA USADA... AL LLEGAR AL HOSPITAL DE LA RESURRECCIÓN DE VALLADOLID}

Frente al vestido a la moda en la Corte madrileña (ropa francesa, casaca, chupa y calzón con sombrero de tres vientos; junto a las más tradicionales capas, ropillas, monteras o chalecos), a lo largo del siglo XVIII los vacíos y carencias caracterizaron los ropajes populares masculinos y femeninos dejados en el principal hospital vallisoletano, el de la Resurrección ${ }^{16}$. Prendas -o harapos llenos de piojos y sarnososportadas por aquellos pobres enfermos al acceder a la sala hospitalaria entre $1701 \mathrm{y}$ 1790, perfectamente anotadas entonces, toda vez que (salvo unas pocas referencias a "se quedó vestido con..." ${ }^{17}$ ) bien podrían venderse al mejor postor en pública almoneda para aprovecharse como ropa de segunda mano tras cada previsible deceso ${ }^{18}$.

No existía en aquellos espacios públicos tan transitados ninguna duda entre la transformación modernizadora de pensar que el buen paño en el arca se vende o la necesidad de comprar en un escaparate iluminado, cuando sus consumos eran prácticamente inexistentes. Muy al contrario, muestra las vestimentas más usuales de la pobre cultura material textil popular de entonces.

Las conclusiones resultan nítidas: una tipología muy concreta de ropajes, repetitiva, escasa y con poca evolución, y con predominio de las calidades inferiores.

Entre las prendas registradas a aquellos vallisoletanos y vallisoletanas en su

\footnotetext{
${ }^{16}$ Archivo Histórico Provincial de Valladolid (en adelante $A H P V a$ ), Fondo del Hospital de la Resurrección (en adelante HR). Libros de Entradas de Enfermos (1701-1705): caja 103; (17861790): cajas 109 y 110; y Libros de Enfermas (1701-1705): caja 102; y (1786-1790): caja 108. ${ }^{17}$ AHPVa, HR; 1786. 28 mujeres mantuvieron puestas sus camisas: "quedó con la camisa, el jubón y dos pañuelos de seda; dio la mantilla"; "la camisa, de la que no me hago cargo, para cubrir sus carnes y para su decencia". Entre los varones: "no me hago cargo de su camisa, calzoncillos y dos pañuelos viejos, porque se quedó con ellos"; "se quedó con su chupín y justillo"; "sólo con sus calzoncillos".

${ }^{18}$ M. GARCÍA FERNÁNDEZ (2015). "Los ropajes populares urbanos recogidos en el Hospital de la Resurrección de Valladolid. Siglo XVIII". En Arias de Saavedra, I. y López-Guadalupe, M.L. (eds.). Vida cotidiana en la monarquía hispánica. Tiempos y espacios. Granada: Universidad de Granada, pp. 347-367.
} 
mayoría (naturalmente con muy pocos trajes infantiles: "manteítos"; "chupa, calzón, medias, zapatos y camisa, todo del hospicio"; "tal cual de San José, como expósito") tras su ingreso en el hospital local (algunos pocos por segunda vez, aunque solían entrar exactamente con la misma ropa que la primera, confirmando sus hábitos característicos) sobresale que el modelo de vestimenta masculino popular evolucionó desde el clásico calzón y el jubón a acompañar al primero con chupa y camisa, abrigados siempre por capas ${ }^{19} \mathrm{y}$ monteras, pero con muy poca presencia de las casacas. Ellas pasaron, sin abandonarlas nunca, del guardapiés y la mantilla, al manteo (destacando el número de faldas así denominadas ${ }^{20}$ : un par en 1700, para llegar a portar muchas de las enfermas hasta tres y cinco en 1790) con sus camisas y juboncillos. Y todos incrementando su avituallamiento normalizado de zapatos y medias. Aumentando lentamente las cantidades medias por individuo. Esas eran las piezas definitorias del simple vestuario castellano de entonces, y sin apenas capacidad de repuesto.

Conociéndose cada vez más el nomenclátor específico de aquellos ropajes, su estado de conservación sólo mejoraba mínimamente, sin que las prendas inventariadas como buenas nunca superasen el $15 \%$. Además, la falta de higiene y la suciedad continuaba destacando y caracterizando a aquellos numerosos pobres castellanos ${ }^{21}$.

Siempre con escaso atavío personal, la cantidad media de prendas por individuo aumentaba hasta casi duplicarse (pasó en noventa años de cuatro a ocho): de forma muy patente entre ellas, pero con una significativa mayor variedad de prendas masculinas (hasta 48). Entre los decenios extremos del siglo XVIII el número de piezas textiles se multiplicó en un 75\%: mientras a comienzos de la centuria predominaban apenas 3-4, lo más característico a finales eran ya las 7-10 por enfermo. Otra cuestión, en cambio, era que seguían reproduciéndose sin modificaciones la misma tipología para ambos sexos.

${ }^{19}$ AHPVa, HR; En 1786: once varones con su "vestido con capa" (uno "con cabriolé"; "la capa azul con galón y su vuelta de terciopelo de pelo rallado, buena") frente a cuatro "sin la capa". 20 "De todas las faldas de que están cargadas, que llevan a menudo más de ocho, una es especial, y sin la cual no se atreverían a dejarse ver: la llaman guardapiés, la de encima, siempre demasiado larga y con una alforza en medio para alargarla cuando el borde está usado [no porque sean muy económicas, sólo es la costumbre la que ha conservado esa moda -cuidan de comprar nuevas en cuanto la parte baja empieza a usarse; las perdono-]"; García Mercadal. $O p$. cit.; Labat (1705). Viajes en España, tomo IV, p. 519.

21 "Los criados van a cuerpo; por la suciedad y el desorden en sus ropas, todas andrajosas, los tomaría por verdugos"; Ibid.; Caimo (1755). Viajes de España, tomo IV, p. 778. 
Tabla 1. Calidades de las prendas; Hospital de la Resurrección de Valladolid, s. XVIII

\begin{tabular}{|l|c|c|}
\cline { 2 - 3 } \multicolumn{1}{c|}{} & $\mathbf{1 7 0 1 - 1 7 0 5}$ & $\mathbf{1 7 8 6 - 1 7 9 0}$ \\
\hline Muy viejas / Malísimas & $96 \%$ & $58 \%$ \\
\hline Medianas & $3 \%$ & $28 \%$ \\
\hline Buenas / Muy buenas & $1 \%$ & $14 \%$ \\
\hline
\end{tabular}

Sus cantidades y calidades presentan una evolución muy similar a las prendas aparecidas en las dotes femeninas. Lógicamente, los inventarios matrimoniales en mayor cuantía y con más variedad de piezas (aunque nunca zapatos ni sombreros, bastante presentes aquí sin embargo) y de tejidos, en función de los numerosos pañuelos y vestidos tasados (además de la muy simbólica ropa blanca de cama) como aportes dotales a las necesidades familiares primarias $^{22}$.

Tabla 2. Cantidad de prendas entregadas en el HRV, siglo XVIII

\begin{tabular}{|c|c|c|c|c|}
\cline { 2 - 5 } \multicolumn{1}{c|}{} & \multicolumn{2}{c|}{ Enfermas } & \multicolumn{2}{c|}{ Enfermos } \\
\cline { 2 - 5 } & $\mathbf{1 7 0 1}$ & $\mathbf{1 7 9 0}$ & $\mathbf{1 7 0 1}$ & $\mathbf{1 7 9 0}$ \\
\hline Media de prendas detalladas & 5 & 8 & 4 & 7 \\
\hline $\mathbf{N}^{\mathbf{0}}$ de prendas diferentes & 22 & 34 & 30 & 48 \\
\hline $1-2$ & $8 \%$ & $1 \%$ & $21 \%$ & $2 \%$ \\
\hline $3-4$ & $37 \%$ & $2 \%$ & $37 \%$ & $6 \%$ \\
\hline $5-6$ & $31 \%$ & $15 \%$ & $33 \%$ & $35 \%$ \\
\hline $7-10$ & $23 \%$ & $70 \%$ & $9 \%$ & $54 \%$ \\
\hline $11-19$ & $1 \%$ & $12 \%$ & $0 \%$ & $3 \%$ \\
\hline
\end{tabular}

Con un escaso mundo de colores para ambos sexos, con predominio de amuscos, pardos o pajizos, pero también diferentes tintes, gamas y tonos en una misma persona ${ }^{23}$.

Sobre sus cabezas, bastantes pañuelos; con mantos y mantillas protectoras o

\footnotetext{
${ }^{22}$ M. GARCÍA FERNÁNDEZ y R.Ma DÁVILA CORONA (2005). "Vestirse y vestir la casa. El consumo de productos textiles en Valladolid (1700-1860)". Obradoiro de Historia Moderna, 14, pp. 141-174.

${ }^{23}$ AHPVa, HR; En 1786 una mujer Portaba dieciséis piezas: "dos manteos azules, uno encarnado y otro pajizo, dos jubones de tripe, mantilla blanca, un pañuelo de cabeza y la cotilla roja"; Entre ellos: "todo pardo"... “calzón y medias azules; chamarreta encarnada"; "capa negra, chupa, calzón y chupín azules”.
} 
encubridoras; y sombreros o monteras típicamente masculinas.

Una sola referencia al moderno surtú, al higiénico calzoncillo maragato o a la mínima marca diferenciadora (frente a la de la tierra o del país) manteo franciscano. El resto, sin adjetivos... o nada positivos; únicamente, roto, muy deteriorado y viejo.

Muy pocos casos modélicos de personas decentemente ataviadas (con "camisa sin usar y dos pares de zapatos" $)^{24}$, junto a una mayoría popular ciertamente paupérrima y reconocible por su "manteo viejísimo, jubón infeliz y mantilla derrotada" 25 .

Algunas otras claves interpretativas se relacionan con el hecho de que mientras dos terceras partes entraban descalzas en 1701, ya sólo lo hacían el $10 \%$ de ellos y casi ninguna mujer a finales de la centuria, aunque no siempre portasen las dos piezas o

${ }^{24}$ AHPVa, HR; Hombres. 1701. "Ocho piezas: capa de cien hilos, chupa y calzón de droguete, medias y zapatos nuevos de cordobán, anguarina y justillo"; "nueve: capa de paño, jubón de droguete, calzón de raso, medias de seda, zapatos de cordobán, anguarina de paño de Segovia y su montera"; "capa y calzón de paño nuevos y jubón de estameña azul con mangas"; "casaca de paño, chupa de droguete, calzón de felpa y medias azules"; "todas nuevas: calzón de paño, capa de Sobremonte, dos jubones de estameña y calzoncillos"; "entre diez piezas: dos jubones de estameña nuevos; calzones, su anguarina y dos camisas".

Hombres. 1786. Hasta tres camisas uno, otro dos chalecos, charreteras, dos corbatines. "Casaca y chupa azules, calzones encarnados con casaca, zapatos, botines, sombrero con galón, camisa y cinturón". "Casaca, chupa, calzones, chaleco, medias, zapatos con hebilla de metal, sombrero y camisa". "Calzón de tripe, montera malagueña de terciopelo negro, cabriolé azul, chaleco de buena fábrica y sus calzoncillos".

Mujeres. 1701. "Anguarina nueva, por hacer". "Mantilla de la nueva fábrica". "Dos manteos de vuelta, guardapiés nuevo, jubón de estameña y mantillina negra". "Jubón azul, delantal de lamparilla y manteo frailengo". "Guardapiés y tapapiés, basquiña de pelo de camello, medias de lana, anguarina de cien hilos, justillo de escarlatina y ligas doradas". "Mantilla de cien hilos, delantal de tafetán, jubón de estameña, una basquiña de lamparilla nueva y otra andada y tapapiés de bayeta". "Manteo de Palencia nuevo, otro verde, dos encarnados, uno de estameña verde viejo, almilla de escarlatín, mantilla de cien hilos y anguarina de paño". "Justillo sin mangas de estameña, delantal de estameña nuevo, guardapiés encarnado viejo y mantilla de bayeta". "Manteo paño y mantillas de Somonte y Frechilla".

${ }^{25}$ AHPVa, HR; Hombres. 1701. "Sus ropas no eran propias". Su única prenda "capa de paño de las Navas amusca, en poder de su convecino". Todo: "corbata nueva y dos camisas viejas". Sólo contaba con dos piezas: calzón y anguarina de paño de Astudillo. "Muy roto". "No vale cosa alguna".

Mujeres. 1786. "Infeliz, sin camisa". Todo viejo con manteo nuevo. Sin Ropa. Del Hospicio. Nada vale. De muy poco valor. Toda vieja. Pobre. Infelicísima. La necesaria. A lavar por sarna. Toda de sayal viejo. No valía cosa alguna. "Bien pobre el resto". 
fuesen simples albarcas de madera ${ }^{26}$. Además, quienes lucían habitualmente medias cubriendo sus piernas ascendieron del $40 \%$ a más del $80 \%$. Lo mismo que la zapatería (hasta alcanzar el 93\% femenino); con su característica hebilla al menos un $12 \%$.

Portadores de algunos otros aditamentos y complementos: sacros (relicarios y rosarios), joyas (botones, hebillas y medallas de plata) y hasta objetos personales y ya demostrativos de una cierta cultura material en clave de civilización ${ }^{27}$, al aparecer con un reloj, un bastón o una gaita.

No pocas mejoras sobre una base textil al límite de una apariencia decente.

En suma, computados los datos de un $68 \%$ de aquellos enfermos a quienes se les intervino alguna prenda (el mayor control de la información y registro de los ropajes entrados debe vincularse a su posible-segura transformación en dinero contante tras sus fallecimientos), sólo el $44 \%$ entre las mujeres de 1700 , pero ya un $86 \%$ a finales de la centuria ilustrada (presentando ellos también su máximo en el $75 \%$, y eso que un $15 \%$ entonces eran uniformes militares): los hombres aparecían con calzón, capa y jubón (zapatos y medias), más los habituales sombreros ${ }^{28}$; las prendas modélicas

26 "Zapatos la mayor parte de cuerda; los hacen ellos mismos"; García Mercadal. Op. cit.; Herauld (1669). Memorias, tomo III, p. 570. AHPVa, HR; Mujeres. 1786. Zapatos de madera. "Únicamente un zapato y una media". Sólo una calceta. Zapatos nuevos, pero sólo una hebilla. Zapatos del Hospicio. Con medias y calcetas, pero sin zapatos. Únicamente un zapato y una calceta, con camisa buena.

Hombres. 1786. Botas de montar de becerrillo. Hebillas de similor. "Zapatos viejos, botines y sus alpargatas". "Zapatos nuevos y botines de piel". "Dos pares de zapatos en un fardel". Zapatos nuevos y el resto de la ropa vieja. Sólo un zapato, pero el chaleco muy bueno. "Medias nuevas con abarcas".

${ }^{27}$ N. ELIAS (1989). El proceso de la civilización. Investigaciones socio y psicogenéticas. México: FCE.

28 "Ningún muchacho olvidaría su capa, que jamás dejará de acompañar el resto del vestido español y que $n$ siquiera se quitan al morir, porque no creerían conducir a un muerto decentemente a la sepultura si no la llevase sobre los hombros. He visto a muchos pobres descalzos, con la cabeza al aire y sin camisa, pero con su capa: esa pieza es esencial"; García Mercadal. Op. cit.; Labat. Op. cit., p. 520. "Todas las gentes de condición van vestidos a la francesa; tan sólo los magistrados, los campesinos y algunos viejos retienen la moda antigua de la golilla; la mayoría lleva grandes capas que les sirve para todos los usos (para ocultar su traje cuando no vale nada -tan frecuente-, cubrirse en invierno, ora de colchón, ora de manta)"; Ibid.; Silhouette (1729). Viaje de España, tomo IV, p. 613. "Noche y día tropezaba con gentes ataviadas con los enormes sombreros de alas gachas y las capas negras, que les caían desde el rostro hasta los talones. Traje extraño... máscaras"; Ibid.; Casanova (1767). Memorias, tomo V, p. 145 . 
femeninas: el guardapiés o manteo y las mantillas ${ }^{29}$; dos tercios portaban mantillas y delantales; la mitad, jubón y delantal; y bastantes de las ingresadas camisas, medias y su zapatería.

Crecía en un 50\% la media de prendas masculinas (al igual que entre ellas). No obstante, la cantidad final era un tercio superior que las portadas por las féminas (entre 22 y 48). Aunque sin tasar, eran igual de buenas para ambos sexos: únicamente un 12\%-13\%; medianas, una cuarta parte; malas, el $46 \%$ de las adscritas a ellos y el $58 \%$ femenino; cuando en 1701 por encima del $90 \%$ eran consideradas malísimas ${ }^{30}$.

Reconociéndose distintos tipos humanos por su atuendo modélico. Algún religioso ${ }^{31}$. Lobas y manteos estudiantiles ${ }^{32}$. Varios segadores gallegos y trashumantes con sus ropas pardas de sayal y alguna vara de lienzo en el costal. Paisanos con su

29 "Muestran un gran gusto en el uso de la mantilla -muselina o velo que cubre cabeza y hombros-, reemplazando a la cofia. Ninguna extranjera puede alcanzar su facilidad y elegancia en colocar ese simple atavío, ligero como alas y que parece no tener peso. En el paseo visten lujosamente con ellas". "Las señoras van tan bien disfrazadas que no es fácil reconocerlas. Su vestido es particular de este país: todas llevan la basquiña de sarga negra y la mantilla, que sirve para el doble objeto de capa y velo (grande para ocultar el rostro). De ese modo pueden ir donde les plazca"; Ibid.; Townsend. Op. cit., p. 77.

${ }^{30}$ AHPVa, HR; "Se vendió la capa, y se dijeron doce misas por su alma (24 reales)". "Toda la ropa valió 25 rls. y medio". "Sus ocho piezas, en estado mediano, se vendieron en 18 rls.". Todo: 9 reales en dinero.

${ }^{31}$ AHPVa, HR; 1701. "Calzón, sotana talar y anguarina de bayeta, y mochila cerrada con candado".

1786. Otro presbítero vallisoletano: “capa, balandrán, chupa, casaca, chaleco, calzón, dos pares de medias pajizas, calzoncillos, zapatos con hebilla y sombrero; todo algo decente". Un diácono: "manteo de bayeta, capa, dos pares de calzones (nuevo y usado), chaleco de felpa, dos pares de medias, dos pares de calcetas, dos pares de zapatos con hebilla y sombrero; no me hago cargo de su chupa con justillo, camisa y pañuelo, porque quedose con ello, así como tampoco de la ropa blanca que mandó a lavar".

32 AHPVa, HR; Un estudiante de Osma de 28 años: "capa buena de Somonte, jubón de estameña, camisa buena, calzones de camuza y anguarina de paño de la Sierra". "Sólo loba y manteo". Un artista: "sólo con capa y calzones". Otro licenciado "con su manteo, loba, ropilla y calzón". 
"montera de paño al uso de la tierra". Criadas ${ }^{33}$. Peregrinos ${ }^{34}$. Pero ninguna maja-o ${ }^{35}$ ni petimetre ${ }^{36}$ (muy pocas redecillas; aunque sí apareciesen mantillas y pañuelos ${ }^{37}$ ).

Con casi nada ${ }^{38}$, todo encima y dentro de sus alforjas... o mostrando algunos posibles (portando piezas bastantes) y recambios decentes ${ }^{39}$. En contadas ocasiones con ropa blanca y mudas interiores ${ }^{40}$. Acercándose a las modas con décadas de retraso, aunque en cantidades y calidades ciertamente reducidas y pobres.

${ }^{33}$ AHPVa, HR; 1786. Sirvienta en Valladolid con "dos bolsos, rosario, alfiletero y otros chismes".

${ }^{34}$ AHPVa, HR; 1786. Un peregrino: "dos calzones (blanco y negro), dos pares de medias, zapatos, dos camisas, sombrero, casaca buena, esclavina, dos chalecos (blanco y paño), fardo y calabaza". Otro, natural de Monforte de Lemos "lleva calabaza y gabardina parda". Toda la ropa de "una vecina de París, muchacha de trece años, viandantes por España", de ningún valor. ${ }^{35}$ Majos: "especie de bravucones de baja estofa. Ocultan sus facciones bajo un gorro de tela oscura llamado montera y su larga espada bajo la amplia capa. Las majas rivalizan con ellos en porte, lenguaje, actitud y libertinaje. Gentes de rango han tomado como modelos a estos héroes del populacho, adoptando su porte y modales; satisfechos cuando logran un exacto parecido"; García Mercadal. Op. cit.; Bourgoing (1777). Un paseo por España durante la revolución francesa, tomo V, p. 510.

${ }^{36}$ A. PEÑAFIEL RAMÓN (2006). Los rostros del ocio: paseantes y paseos en la Murcia del Setecientos. Murcia: Universidad de Murcia.

${ }^{37}$ AHPVa, HR; Pañuelo de tres esquinas. Mantilla y pañuelo de cuello. Un fardo con un pañuelo de seda.

${ }^{38}$ AHPVa, HR; "Unos trapos por ropa". "Nada más que dos camisas buenas y el cinto". "Capa derrotada, chupa viejísima y calzones desbaratados". Farrapos de ningún valor. Que todo no vale dinero. No vale nada; ni un cuarto. Únicamente la camisa. Media camisa. Todo: su ropa blanca. "Calzones y zapatos viejos; nada más". Sólo una media, calceta y un zapato. Enredillos; trebejos. No vale blanca ni maravedí.

${ }^{39}$ AHPVa, HR; En 1786, un hombre con 16 piezas (dos calzones, dos camisas y dos monteras)

"y en la alforja: una sotana, otro calzón, un manteo, otra camisa y otra montera -todo muy viejo-, más una capa parda no muy vieja". Otro pobre inventariaba nueve prendas en su costal. Mujeres. 1786. Con quince piezas, seis camisas. Entre 19 prendas, cuatro pañuelos.

${ }^{40}$ AHPVa, HR; Una vizcaína en 1786, catorce piezas diferentes, "más colchón, dos almohadas con fundas, manta grande y pequeña, paño de manos, servilleta y unos pendientes pequeños". Cuatro mantas, jergones y sábanas. Una manta de muda. "Dos mudas de ropa blanca interior". 
Tabla 3. Reiteración de las prendas aparecidas en el HRV, siglo XVIII

\begin{tabular}{|c|c|c|c|c|c|}
\hline & \multicolumn{2}{|c|}{ Femeninas } & & \multicolumn{2}{|c|}{ Masculinas } \\
\hline & 1701 & 1790 & & 1701 & 1790 \\
\hline Enfermas & 302 & 1.097 & Enfermos & 440 & 1.321 \\
\hline Manteo & 299 & 2.517 & Capa & 307 & 685 \\
\hline Guardapiés & 302 & 94 & Anguarina & 149 & 112 \\
\hline Jubón & 134 & 917 & Jubón & 188 & 36 \\
\hline Basquiña & 49 & 65 & Ropilla & 109 & 17 \\
\hline Justillo & 41 & 109 & Justillo & 11 & 223 \\
\hline Delantal & 127 & 565 & Coleto & 64 & 37 \\
\hline Almilla & 20 & 12 & Almilla & 11 & 8 \\
\hline Capote & 1 & 47 & Capote & 11 & 6 \\
\hline Camisa & 13 & 912 & Camisa & 16 & 148 \\
\hline Enaguas & 3 & 49 & Calzoncillos & 12 & 149 \\
\hline Calcetas & 9 & 69 & Calcetas & 16 & 116 \\
\hline Medias & 106 & 968 & Medias & 171 & 1.068 \\
\hline Mantilla & 205 & 678 & Casaca & 53 & 52 \\
\hline Mantillina & 54 & & Chupa & 25 & 1.252 \\
\hline Pañuelo & 11 & 528 & Calzón & 379 & 1.291 \\
\hline \multirow[t]{2}{*}{ Dengue } & & 154 & Chaleco & & 355 \\
\hline & & & Chamarreta & & 53 \\
\hline Sombrero & & 2 & Sombrero & 89 & 635 \\
\hline Zapatos & 107 & 1.018 & Zapatos & 159 & 1.295 \\
\hline
\end{tabular}

\section{OTRA FÓRMULA DE TRANSMISIÓN DE LOS ROPAJES AJENA A LA TIENDA Y AL MERCADO DE PRIMERA MANO: LOS LEGADOS TESTAMENTARIOS}

Testamentos e inventarios de bienes muestran la existencia de cierta liquidez en no pocas casas castellanas. Alguna viuda hilandera bien guardaba cuatro pesos fuertes de plata y reales de vellón en un baúl cerrado con dos llaves, "envueltos en un pedazo de lienzo viejo". Lo mismo que lecheras y labradoras lo ocultaban en "una de sus arcas". Los zapateros podían tenerlos depositados en una cestilla de mimbres, en una bolsita, dentro de un arcón y hasta en una caja de hojadelata. El recurso a las navetas de los 
escritorios privilegiaba a sus dueños, aunque sin ser privativo de los acomodados, al encontrarse también en las habitaciones de varios maestros sastres, al igual que podían aparecer "en la gaveta de una mesa sita en el cuarto en el que dormía"41.

Los mercaderes ofrecían una mayor variedad de cajas fuertes. Por ejemplo, detallaban su ubicación "en el cuarto librería, oculto tras la efigie y aderezo de un Santo Cristo... en un talego pequeño de lienzo"; en un arcón de la sala; en el "escritorio donde dicho difunto regularmente ponía el dinero"; en "la naveta de la mesa de la tienda"; o, además de en varios hatillos ocultos dentro del mostrador comercial, en el interior del "escritorio de Salamanca que se halla en un cuartito detrás de la alcoba del aposento principal, donde murió... cuya llave se hallaba recogida"42.

Dinero disponible en bolsitas y talegos; en cofres, arcas y baúles; en cajones y navetas; en escritorios y papeleras; en alcobas y en el "cuarto del gabinete de los papeles"; o en el "arcón que está detrás de la cama en que murió el dicho difunto"...

Ciertas posibilidades de compra... para una minoría. No obstante, una de las claves para frenar la demanda de novedades textiles, aunque las necesidades de vestuario ya estuviesen impuestas, se centra en el peso de la transmisión de ropajes de una generación a otra sin pasar, de nuevo, por su pago al tendero, tras constatarse que las cláusulas testamentarias certifican la cotidianeidad de tales traspasos.

Cuando no existe un mercado nacional y el acceso a la tienda estable o a la feria estacional limitaban el aprovisionamiento textil; cuando las ventas de segunda mano estaban absolutamente generalizadas; cuando todavía el autoconsumo, tejer para el interior de la casa familiar, era práctica habitual en el mundo rural y urbano; cuando la renta disponible y el ahorro no aumentaban... las mandas testamentarias de ropas estarían plenamente asentadas y se mantendrían, máxime entre los grupos populares.

${ }^{41}$ AHPVa, Sección de Protocolos Notariales (en adelante $P N$ ); diferentes escrituras testamentarias fechadas entre 1740 y 1768.

42 AHPVa, PN; Diferentes escrituras testamentarias fechadas entre 1723 y 1791.

Algunos escribanos y procuradores del número urbanos no custodiaban con más esmero sus más amplios recursos en efectivo: valía un simple arca de pino (y dentro "unos secretos"), un bote de hoja de lata ubicado en el entresuelo del portal, las navetas del escritorio del cuarto principal de su vivienda o una arquita con su llave. Aun así, los mayordomos debían disponer de lugares de custodia específicos para sus abultados talegos: como el "archivo que tenía en los cuartos principales de sus habitaciones", mueble complementario al arcón grande de nogal y al "bufete salamanquino independiente" ubicados en el despacho; $A H P V a, P N$; Diferentes escrituras testamentarias fechadas entre 1713 y 1779. 
Dos terceras partes de los testadores vallisoletanos realizaron algún tipo de legado durante el siglo XVIII. Algo más las mujeres, en las zonas rurales y a comienzos de la centuria, pero siempre de forma constante como práctica familiar muy extendida. Sus beneficiarios presentaban una clara diferenciación de género a favor de ellas, concentrándose entre los miembros próximos de la propia familia extensa.

Tabla 4. Los legados testamentarios; Valladolid y provincia, XVIII; en porcentajes ${ }^{43}$

\begin{tabular}{|l|c|c|c|c|}
\cline { 2 - 5 } \multicolumn{1}{c|}{} & Legadores & Beneficiarios: Mujeres & Sobrinos-as & Familiares \\
\hline Valladolid ciudad & 62 & 66 & 36 & 52 \\
\hline Zona rural & 66 & 64 & 36 & 53 \\
\hline $1700-1704$ & 66 & & & 51 \\
\hline $1750-1754$ & 60 & & & 53 \\
\hline $1795-1799$ & 61 & 65 & 37 & 55 \\
\hline Hombres & 57 & 66 & & 53 \\
\hline Mujeres & 69 & 64 & 36 & 52 \\
\hline Media & 64 & 6 & & \\
\hline
\end{tabular}

Muchas sobrinas recibieron en aquel instante trascendente del fallecimiento de algún ascendiente diferentes donaciones. La valoración de las mismas resulta imposible de cuantificar por cuanto casi nunca aparecen tasadas y predominaban las mandas genéricas de "toda la ropa de vestir de mi uso", la "ropa blanca existente" o una "cama de ropa". Aun así, su importancia cualitativa resulta notoriamente sobresaliente para comprender la enorme carga de freno a la demanda personalfamiliar de productos semiperecederos que representaba. El surtido de muchas piezas cotidianas, y hasta "muy usadas" y "rotas" ("viejas" o "medianas" y "de buen pasar"...) al lado de algunas otras de enorme carga simbólica por su valor, calidad, exclusividad, notoriedad, antigüedad o novedad encontrarían cabida en este mecanismo de transmisión fuera del mercado.

43 AHPVa, PN; Diferentes Legajos de Valladolid ciudad y su zona rural circundante, 17001800 . 
Tabla 5. Efectos legados por los testadores; Valladolid, 1750-1754; porcentajes $^{44}$

\begin{tabular}{|l|c|c|c|c|c|c|c|c|c|c|}
\cline { 2 - 12 } \multicolumn{1}{c|}{} & $(\mathbf{1})$ & $\mathbf{( 2 )}$ & $\mathbf{( 3 )}$ & $\mathbf{( 4 )}$ & $\mathbf{( 5 )}$ & $\mathbf{( 6 )}$ & $\mathbf{( 7 )}$ & $\mathbf{( 8 )}$ & $\mathbf{( 9 )}$ & $/$ (A) \\
\hline Hombres & 15 & 10 & 3 & 3 & 7 & 8 & 33 & 7 & 14 & 25 \\
\hline Mujeres & 21 & 14 & 4 & 2 & 9 & 14 & 23 & 5 & 8 & 35 \\
\hline Media & 16 & 12 & 4 & 2 & 8 & 11 & 27 & 6 & 11 & 31 \\
\hline
\end{tabular}

(1): Vestidos. (2): Ropa Blanca. (3): Mobiliario. (4): Menaje Doméstico. (5): Objetos de Adorno. (6): Joyas. (7): Dinero. (8): Bienes Raíces e Inmuebles. (9): Otros. / (A): Total Textil.

De entre aquella amplísima tipología de enseres donados interesa resaltar los relacionados con el acondicionamiento del hogar y el vestido personal, por cuanto constituían las partidas principales del consumo no alimenticio castellano. Aunque se transmitieron entonces distintas -siempre pequeñas- cantidades en reales de vellón y el patrimonio raíz o las casas también circulaban por esta vía fuera del tronco de los legítimos herederos, a mediados del siglo XVIII las prendas de vestir junto a la ropa blanca de cama alcanzaban porcentajes muy sobresalientes, además de repartir diversos objetos de adorno, mobiliario y menaje doméstico (otro 14\% de los mismos). La joyería superaba otro $10 \%$, pero la clave de aquellos legados eran los productos textiles.

Mientras únicamente el $25 \%$ de aquellas mandas masculinas estaba compuesto por géneros textiles, simplemente los vestidos ya casi alcanzaban ese mismo porcentaje entre las mujeres, y llegando a superar la tercera parte de los legados efectuados por ellas. Ese protagonismo femenino se pone también de manifiesto en todas las donaciones que incorporaban objetos del hogar o ajuar vestimentario; los hombres sólo las superaban cuando incluían otro tipo de bienes raíces o patrimoniales.

Tabla 6. Efectos legados por testadores y testadoras; Valladolid, 1750-54; porcentajes

\begin{tabular}{|l|c|c|c|c|}
\cline { 2 - 5 } \multicolumn{1}{c|}{} & Géneros Textiles & Ajuar Doméstico & Joyas & Otros \\
\hline Hombres & 33 & 41 & 25 & 58 \\
\hline Mujeres & 67 & 59 & 75 & 42 \\
\hline
\end{tabular}

Un amplio espectro de clérigos, militares y criados sobresalían en esos legados del ajuar familiar, mientras que sólo la nobleza bajaba de la media general al decantarse

\footnotetext{
${ }^{44}$ AHPVa, PN; Diferentes Legajos de Valladolid ciudad, 1750-1754.
} 
por otros bienes más suntuosos o de adorno. Ningún grupo social se alejaba de esa extendida práctica testamentaria de tanta trascendencia económica entonces.

Tabla 7. Efectos legados por los testadores en clave social; Valladolid, 1750-54; porcentajes

\begin{tabular}{|l|c|c|c|c|c|c|c|c|l|}
\cline { 2 - 11 } \multicolumn{1}{c|}{} & $(\mathbf{1})$ & $\mathbf{( 2 )}$ & $\mathbf{( 3 )}$ & $\mathbf{( 4 )}$ & $\mathbf{( 5 )}$ & $/$ & $\mathbf{( A )}$ & $\mathbf{( B )}$ & (C) \\
\hline Clérigos & 12 & 13 & 7 & 6 & 10 & & 25 & 23 & 48 \\
\hline Nobles & 10 & & & & 14 & & 10 & 14 & 24 \\
\hline Criados & 23 & 13 & & 1 & 8 & & 36 & 9 & 45 \\
\hline Comerciantes & 23 & 6 & 2 & 2 & 6 & & 29 & 10 & 39 \\
\hline Artesanos & 20 & 8 & 2 & 2 & 5 & & 28 & 9 & 37 \\
\hline Profesionales Liberales & 10 & 13 & 3 & & 9 & & 23 & 12 & 35 \\
\hline Militares & 22 & 11 & 6 & & 8 & & 33 & 14 & 47 \\
\hline Empleados & 13 & 13 & 2 & 1 & 9 & & 26 & 12 & 38 \\
\hline Labradores & 18 & 10 & 2 & 2 & & & 28 & 4 & 32 \\
\hline
\end{tabular}

(1): Vestidos. (2): Ropa Blanca. (3): Mobiliario. (4): Menaje Doméstico. (5): Objetos de Adorno. / (A): Géneros Textiles. (B): Objetos de Casa. (C): Ajuar Familiar.

Dentro de la tipología de las prendas detectadas sobresalen varias cuestiones. Tejidos y piezas masculinas y femeninas se repetían con insistencia, mostrando escasas novedades y pocas variaciones en cantidades, variedades y calidades... y precisamente eran los mismos ropajes que se encontraban en el hospital vallisoletano. Predominaba el peso de la tradición, aunque su terminología pudiese variar en función de denominaciones geográficas o temporales concretas, como ocurre con las siempre imprescindibles faldas, unas veces manteos, otras basquiñas, guardapiés o sayas.

Cualquiera de tales ajuares $\mathrm{u}$ objetos de casa se incorporaban mediante este mecanismo a una redistribución asidua para la reutilización popular y el disfrute de sus familiares y vecinos cercanos. Una red de donaciones interesadas para ambas partes; en pago de servicios pasados o de cara a un beneficio inmediato futuro (para satisfacer el encargo del trabajo de realizar las ofrendas añales sobre la sepultura del oferente, etc.): "por lo bien que me ha servido... y espero lo continúe de aquí en adelante".

Además de la frecuencia de los legados espiritualizados o de contenido sacro y salvífico, proliferaban aquellas mandas caritativas o afectivas dentro del seno familiar ("por el mucho cariño que me ha tenido", "en recompensa del amor que nos hemos profesado", "en memoria de nuestra amistad", "por los muchos favores que le debo" o 
"para ayuda de su mejor acomodo") $)^{45}$. Aportes y pagos en especie textil que satisfacían necesidades vestimentarias básicas pero que no animaban al consumo de novedades.

Diferentes sobrinas consiguieron así cuantiosos ropajes y lutos de bayeta negra.

A mi prima "una cama de ropa blanca para sus menesteres"46. Todas mis prendas de vestir se repartan entre familiares, sobrinas y la mujer de mi mayordomo ${ }^{47}$. Mando a mi criada (al igual que a una vecina) "una cama entera, compuesta de dos colchones, dos mantas, cuatro sábanas, cuatro almohadas y su colcha de la India"; lo mismo a otra, hermana de la anterior, "que serán las primeras en repartirse los vestidos", "por su fidelidad y cariño, porque por tanto tiempo me han servido bien... y por ser huérfanas, mis albaceas miren por su virtud y conveniencias en cuanto les sea posible"; y a mis dos esclavas: "las dejo libres en su libertad natural, y se las de media cama (jergón, colchón, manta, dos sábanas y dos almohadas)"; mis vestidos y demás ropajes usados "se dividan entre mis cuatro doncellas y las dos morenas, con la condición de que estén en mi casa y servicio al tiempo de mi muerte, porque habiendo salido antes este legado sea nulo" 48 . "Por su diligencia y para que mejor progrese" mi joven criada, tres colchones, varias prendas de ropa blanca y todas mis vestiduras exteriores ${ }^{49}$.

Mandas poco cuantiosas (no tasadas)... pero muy significativas. "A mi amiga, un abanico, el mejor que tengo, en renovación de nuestra antigua amistad... y perdone la cortedad de estas chucherías"; "se reparta toda la ropa blanca de cama que poseo actualmente entre los parientes pobres de mi lugar, a proporción de su necesidad" 50 .

${ }^{45}$ M. GARCÍA FERNÁNDEZ (1995). Herencia y patrimonio familiar en la Castilla del Antiguo Régimen (1650-1834). Efectos socioeconómicos de la muerte y la partición de bienes. Valladolid: Universidad de Valladolid, pp. 143-178.

${ }^{46}$ AHPVa, PN, Legajo 3368, Valladolid, 1750; testamento de Enrique Navarro Anguiano, procurador del número de la Real Chancillería de Valladolid.

47 AHPVa, PN, Leg. 2900, Valladolid, 1704; testamento de doña María Teresa Zúñiga Sandoval, viuda de don Miguel Santos de León, oidor de la Real Chancillería de Valladolid.

${ }^{48}$ AHPVa, PN, Leg. 3135, ff. 180-183, Valladolid, 1702. Todo eso se repartía, señalando claramente y de forma individualizada sus destinatarias, en el testamento cerrado de doña María Magdalena Pimentel y Fajardo, viuda del marqués de Viana e hija del conde de Benavente.

${ }^{49}$ AHPVa, PN, Leg. 2762, ff. 81-89, Valladolid, 1704; testamento de don Gaspar de Quincoces, canónigo de la iglesia catedral de Palencia e inquisidor apostólico del Santo Oficio de Valladolid.

${ }^{50}$ AHPVa, PN; Diferentes escrituras testamentarias fechadas entre 1750 y 1754. 
Mandas femeninas: por donantes y receptoras; "por estar soltera, en mi casa y compañía"; "en virtud de la obediencia paternal que corresponde" ${ }^{51}$. Y muchas mujeres vinculadas al servicio doméstico: una doncella criada mandaba a otra sirvienta viuda todos sus vestidos ${ }^{52}$; o recibían mudas completas de ropa o camas enteras y hasta las libreas y lutos acostumbrados "para que me perdonen todas mis impertinencias" 53 .

Mandas a pobres, marginados y lisiados. "Por no estar acomodado como los demás e imposibilitado de ganarlo por ser cojo"; "en beneficio y sostén de mi menor"; "para los precisos gastos de su manutención"; "para alivio y socorro de su pobreza"; "por ser soltera y pueda así mejor tomar estado"; "para ayuda de su remedio"; "por contemplar a esta mi sobrina más menesterosa que al resto de los sobrinos que tengo" ${ }^{4}$.

Siempre, remedio de pobrezas, pago de agravios pretéritos y atentos al auxilio de favores futuros. El presbítero y capellán del Oratorio vallisoletano de San Felipe Neri mandaba que a su criada Josefa se la pagase todo lo que se le estuviese debiendo de su salarios más cien ducados, "en atención a la fidelidad y cuidado con que me ha servido; advirtiéndose tiene en mi casa un colchón y alguna otra cosa suya propia; se le entregue lo que dijese pertenecerle porque tengo de ella muy grande satisfacción" 55 .

Mandas simbólicas. Don Cristóbal Fonseca Lorenzo legaba "a su amada consorte" varios espejos, urnas, cuadros, todo el vestuario y el menaje de plata; sus criadas recibieron miles de reales y "las casacas de luto de bayeta negra de cien hilos por los veinticinco años que llevan atendiéndome"; mientras que otros muchos parientes se beneficiaron de su capital "en atención a la sangre que media, y que les estimo... y para que me encomienden a Dios" $"$. Por su parte, muchos militares mandaban sus "capas, casacas, pelucas, sombreros y zapatos de hebilla" (hasta bastones y espadas).

Aunque con algunas extendidas reticencias entre esposos: "mando todos los vestidos de su uso, hábito viudal y lecho cotidiano que considero que por derecho le corresponde... [pero] se ha de mantener en estado de viuda, honesta y recogida" ${ }^{57}$.

Cubriendo activamente necesidades y carencias... para "mejor pasar" o "bien

${ }^{51}$ AHPVa, PN; Diferentes testamentos de 1750-1754.

52 AHPVa, PN, Leg. 2644; Valladolid, 1701; testamento de Ana de Villarroel.

${ }^{53}$ AHPVa, PN; Varios ejemplos en los legados testamentarios de Isidro del Río, vecino de Simancas; Leg. 4134, Valladolid, 1798; o en el Leg. 4188, ff. 307-316, Valladolid, 1797.

${ }^{54}$ AHPVa, PN; Diferentes testamentos de 1750-1754.

${ }^{55}$ AHPVa, PN, Leg. 4132, ff. 470-474; Valladolid, 1796.

${ }^{56}$ AHPVa, PN, Leg. 9298, ff. 113-117; Medina de Rioseco, 1754.

${ }^{57}$ AHPVa, PN, Leg. 3657; Valladolid, 1751. 
casar"... por pura supervivencia o atentos al valor simbólico y afectivo del legado.

Una realidad no sólo palpable en Valladolid ciudad o su provincia y extensible a toda la Castilla interior. Así, por ejemplo, tras el análisis testamentario de un pequeño núcleo rural zamorano, el $50 \%$ de sus cláusulas contienen este tipo de legados de $\mathrm{ropa}^{58}$.

En sus últimas voluntades aparecen continuas referencias a una prenda concreta o a todos los trajes de vestir que posee; se especifica su estado de conservación: a medio usar o nueva o "toda la ropa vieja que tuviere"; se valoran las entregas de "la cama con toda su ropa blanca" o "el colchón donde duermo"; y se advierte con frecuencia la posible reutilización inmediata de múltiples enseres y piezas textiles ("que se haga de una saya raída de estameña parda que al presente tengo"; "la mitad del ferreruelo, para que se parta entre sus dos nueras a partes iguales").

Ya se han esgrimido las universales razones motrices vinculadas a tales legados interesados: "por los buenos servicios que le ha hecho", "por el trabajo de ofrendar su sepultura [como es costumbre en la villa]", "por la asistencia que ha tenido en cuidarla, un manto de estameña parda [anulándose dicha manda en un codicilo]"...

También allí, e incrementándose la proporción cuanto más aislada la población, todas las beneficiadas fueron mujeres (salvo cuatro hombres; dos de ellos nietos):

Tabla 8. El legado de ropas en Villanueva del Campo hacia 1750

\begin{tabular}{|l|c|c|l|c|}
\cline { 2 - 5 } \multicolumn{1}{c|}{} & Beneficiarias & $\mathbf{N}^{\mathbf{0}}$ Mandas recibidas & \multicolumn{1}{c|}{ Prendas } & $\mathbf{N}^{\mathbf{0}}$ \\
\hline Hijas & 8 & 8 & Sayas & 5 \\
\hline Nietas & 4 & 6 & Guardapiés & 3 \\
\hline Sobrinas & 5 & 6 & Basquiñas & 3 \\
\hline Hermanas & 1 & 1 & Jubones & 3 \\
\hline Tías & 1 & 1 & Rebociños & 2 \\
\hline Nueras & 3 & 3 & Almillas & 2 \\
\hline Vecinas & 7 & 8 & Anguarinas & 2 \\
\hline
\end{tabular}

Una de ellas mandaba hasta una docena de piezas de vestir (tres legaron al menos

\footnotetext{
58 Archivo Municipal de Villanueva del Campo, Zamora, Escribano Juan González Román.
} 1748-1750. 
cuatro prendas diferentes)... todo su exiguo guardarropa. Muchas sayas (hasta cinco), junto a varios guardapiés, basquiñas, mantillinas y jubones, además de almillas, rebociños, anguarinas, camisas, justillos, mantos...; sin olvidar la entrega de prendas típicamente masculinas, como las capas y ferreruelos de abrigo, o los clásicos calzones, y apareciendo ya alguna moderna casaca nueva. Así, sin estar totalmente desconectados de las ferias periódicas y de las novedades, primaban las hechuras y géneros más tradicionales transmitidos ininterrumpidamente generación tras generación. Satisfacían necesidades básicas, pero reduciendo mucho el recurso al mercado de primera mano.

Carencia, conservación, escasez y ayuda familiar; demanda y poca oferta nueva.

\section{CONCLUSIONES: CONSUMOS POPULARES ESTANCADOS}

Algunos planteamientos de corriente debate y discusión entonces en la España del XVIII aseguraban que la mujer gastaba en demasía. "[Ellas] arruinan la mayor parte de las casas; una falsa generosidad entre esta nación es la de no ahorrar nada para el sexo"59. "¿Qué fruto es para un pobre hombre comprar seis pares de vestidos a su esposa, en que consume todo su caudal?; estaba la señora mal acostumbrada y poco práctica en miserias... es perdido aquél que se distrae con vestidos demasiados" ${ }^{\prime 60}$.

Sin embargo, miseria, no reposición y escasez caracterizaban las pobres formas de vestir de enfermos de toda condición, ratificadas en el asiduo recurso al legado textil por parte de campesinos y agremiados (clérigos y hasta nobles)... aunque la presencia y regalo de trajes nuevos, con adquisición de no pocas varas de tela para confeccionar ropajes y el coste de la hechura de tales prendas en el momento nupcial, también informe sobre una tendencia al incremento de la demanda popular, cuando la evolución hacia una nueva estética mejor surtida cada vez parecía más generalizada.

¿Únicamente la riqueza definía los comportamientos vestimentarios?; ¿sólo se trataba de una cuestión de género, mientras los hábitos masculinos se petrificaban?

Frente a unas crecientes minorías que cada vez tenían un guardarropa mejor surtido en variedades y calidades, algunos procesos por injurias llegados a los tribunales de justicia incluían como causa notoria el "robo de camisas". Y otra evidencia criminal de primer orden entonces seguía siendo el "destrozo del vestido" como prueba de la existencia de disputas vecinales: las señales dejadas en las prendas

${ }^{59}$ García Mercadal. Op. cit.; Brunel (1665). Viaje de España, tomo 3, pp. 253 y ss.

${ }^{60}$ Guzmán de Alfarache; $2^{\mathrm{a}}$ parte, libro III. 
cotidianas mostraban a las claras conflictos y rencillas muy populares, en la medida en que el desgarro de los ropajes evidenciaba que esa apariencia era muy importante socialmente al reafirmar el protagonismo de la propia tenencia de ciertas piezas y tejidos muy usuales.

El reconocimiento por el atuendo no solía coincidir con un progreso de civilización cuando pobreza, legados familiares, ropavejeros o adquisiciones de segunda mano ${ }^{61}$ seguían caracterizando el consumo castellano.

¿Cuál era la realidad que se imponía entre la mayoría popular?

Muchos gastaban... o no lo hacían pero les gustaría. Distinguiéndose del pobre desharrapado, aunque tampoco se viese demasiada pompa ni lujo entre ellas. La cuestión de estar a la moda comenzaba a colocarse en el centro del progreso cultural moderno frente a aquella otra realidad de la penuria callejera en forma de harapo -tan temido como extendido- o del traspaso de ropas hechas de una generación a otra.

"En vano Francia se esfuerza por introducir aquí con su dominio las maneras corteses de la nación francesa, queriendo corregir sus usos para darles decencia; no todos quieren prestarse". Pero ya, en 1777: afrancesamiento; "se nos imita, aunque se nos ridiculice. Sus modas han penetrado igual que en otros países. Bajo la capa española llevan nuestra indumentaria. Sólo las mujeres del pueblo usan ya la mantilla a todas horas; las demás la utilizan sólo para ocultar el desorden de su tocado. En todo el resto, de pies a cabeza, se someten al cetro de la moda de París. Sus fabricantes se ingenian para servir el gusto elegante más extendido y seguir sus rápidas variaciones" $"$.

¿Cuál de esos principios consumistas rectores debe revalorizarse bajo criterios de

${ }^{61}$ M. GARCÍA FERNÁNDEZ (2013). "Cultura material, consumo, moda e identidades sociales: la almoneda de bienes". En M. García Fernández (dir.). Cultura material y vida cotidiana moderna: Escenarios. Madrid: Sílex, pp. 235-260.

J.M. BARTOLOMÉ BARTOLOMÉ (2011/1). El comercio de oportunidades en la provincia de León: las almonedas urbanas y rurales (1700-1850) [recurso electrónico]. Tiempos Modernos. Revista Electrónica de Historia Moderna, 2011/1, vol. 7, n 22, 19 págs. $<$ http:www.tiempos modernos $>$ [consultado: 01-09-2016].

${ }^{62}$ García Mercadal. Op. cit.; Caimo. Op. cit., p. 790; Bourgoing. Op. cit., p. 502. 
urbanidad y de civilización?: ¿cubriendo desnudeces o triunfo del aparentar?

Las prendas francesas se extendían popularmente, aunque en el amplio extremo más débil de la escala social también prosperaran las carencias y la mera necesidad sobre cualquier concepto de moda. Inmutabilidad y arraigo de ciertos ajuares modélicos fosilizados, junto a notables transformaciones (no sólo urbanas y mostrando poder adquisitivo) en el vestir y la apariencia. Dos modelos de civilización interactuando.

Las zonas rurales parece que contaban con vestidos propios. Durante la segunda mitad del siglo XVIII empezarían a distinguirse los hábitos peculiares de cada región con sus especificidades. Juan Cano de la Cruz y Holmedilla realizó una Colección de trajes de España, tanto antiguos como modernos (1778-1788) muy propia de la época ilustrada, en la que intentaba dar a conocer los distintos ajuares usados en el país. Los ropajes populares cambiaban mucho más lentamente que la moda cortesana, pero también evolucionaban al recibir notables y frecuentes influencias capitalinas. Una de aquellas novedades fue la protagonizada por las majas madrileñas ${ }^{63}$. Los foráneos apreciaban aquella dualidad contrastada: el estilo a la francesa que usaban las señoras elegantes en sus casas, visitas, fiestas y carruajes frente a la uniformidad del uso de simples basquiñas y mantillas como atavío cotidiano, aunque lo mismo escenificase el casticismo al lucir su peculiar traje femenino. Apuntes hospitalarios y dotes así lo corrobora: en muy pocos casos faltaba alguna de esas dos prendas a finales del Setecientos (hasta en fina muselina ${ }^{64}$, como se aprecia en los cartones goyescos para tapices o en los bandos para la entrada notoria en el paseo del Buen Retiro desde 1767).

También Antonio Rodríguez, en su Colección general de los trajes que en la actualidad se usan en España, principiada en el año 1801, retrataba regionalismos heredados, además de mostrar vestidos de la moda internacional y a una gran cantidad

${ }^{63}$ A. LEIRA SÁNCHEZ (2003). El vestido y la moda en tiempos de Goya [recurso electrónico]. Textil e Indumentaria: materias, técnicas y evolución, Facultad de Geografía e Historia de la UCM., pp. 205-219. <http: dialnet.unirioja.es/servlet/libro?código=398393> [consultado: 0109-2016]; o A. LEIRA SÁNCHEZ (2007). "La moda en España durante el siglo XVIII". Indumenta, 0, pp. 87-94.

J. CAPDEVILLA (1796). Rasgo anticurrutático dirigido a las madamitas de nuevo cuño. Con muchas coplas satíricas sobre el amplio vestido-camisa exterior procedente de la Francia revolucionaria.

${ }^{64}$ AHPVa, HR; A finales del XVIII, pocos ciertamente, ya se encuentran bolsos, chalecos y medias de algodón, mantillas de muselina o manteos de indiana, al lado de buenos pañuelos de China o de la India. 
de mujeres a la última ${ }^{65}$, calificándolas siempre como petimetras y nunca de majas.

Reflejaban dos modelos estéticos enfrentados, irreductibles en sus mutuas críticas peyorativas ${ }^{66}$.

Aunque la ropa fuese claro símbolo de estatus, no existía entonces una sociedad consumista: en un escenario moderno, el pasado se desacreditaría por lo nuevo, si bien se mantuvo un fuerte tradicionalismo vestimentario por desconexión o simple pobreza, calificado ya de atrasado (y criticado como retrógrado regionalismo) por las elites capitalinas y los sectores más progresistas.

Culturalmente, únicamente a partir del siglo XVIII lo nuevo es bello, cuando hasta entonces la tradición y la vejez -el tiempo inmemorial, la herencia, la durabilidad sempiterna- siempre habían sido calificativos muy positivos (desde la calidad de los paños o la doctrina política). A partir de ese momento, lo antiguo sería rancio, criticado, mal visto y demostrativo de caduco, estamental y hasta supersticioso.

Para ciertos colectivos, en cambio, lo nuevo significaba revolución. En aquel lenguaje silencioso de símbolos, los géneros viejos seguirían siendo un distintivo de calidad y los bienes macizos estaban ideados y construidos para durar toda la vida, reflejo fehaciente de estabilidad, continuidad familiar y perpetuidad frente a la novedad... contrapunto reaccionario a lo moderno -desacreditado-.

$\mathrm{Ni}$ estética rústica rusoniana ni monos imitadores gerundianos; aunque estimo que mantiene pleno sentido el galdosiano vestir y pensar a la antigua, para una gran mayoría popular la mera necesidad seguía siendo la madre del atuendo ${ }^{67}$, manteniendo consumos estancados por cantidades, calidades y usos... y como reflejo de un modelo de civilización y social claramente diferenciado.

${ }^{65}$ A. RACINET (1870-1890). The Complete Costume History (Köln: Taschen, 2003).

${ }^{66}$ J.M ${ }^{\mathrm{a}}$ BLANCO WHITE (1798). Cartas de España (1972, tomo II, p. 84).

${ }^{67}$ Véanse: L.E. RODÍGUEZ SAN PEDRO-BEZARES y J.L. SÁNCHEZ LORA (2014). Los siglos XVI-XVII: Cultura y vida cotidiana. Madrid: Síntesis. P. SAAVEDRA y H. SOBRADO (2004). El siglo de las Luces. Cultura y vida cotidiana. Madrid: Síntesis, pp. 370-371. G.Á. FRANCO RUBIO (2009). Cosas de la vida. Vivencias y experiencias cotidianas en la España Moderna, Cuadernos de Historia Moderna, Anejos VIII, UCM. D. MUÑOZ NAVARRO (ed.) (2011). Comprar, vender y consumir. Nuevas aportaciones a la historia del consumo en la España moderna. Valencia: Universidad de Valencia. I. ARIAS DE SAAVEDRA ALÍAS (2009). dossier "La vida cotidiana en la España Moderna”. Chronica Nova, 35. 


\section{BIBLIOGRAFÍA}

ARIAS DE SAAVEDRA ALÍAS, I. (2009). dossier "La vida cotidiana en la España Moderna”. Chronica Nova, 35.

BARTOLOMÉ BARTOLOMÉ, J.M. (2011). El comercio de oportunidades en la provincia de León: las almonedas urbanas y rurales (1700-1850) [recurso electrónico]. Tiempos Modernos. Revista Electrónica de Historia Moderna, 2011/1, vol. 7, n 22, 19 págs. <http:www.tiempos modernos>.

BERNIS, C. (2001). El traje y los tipos sociales en El Quijote. Madrid: Visor.

ELIAS, N. (1989). El proceso de la civilización. Investigaciones socio y psicogenéticas. México: FCE.

FRANCO RUBIO, G.Á. (2009). Cosas de la vida. Vivencias y experiencias cotidianas en la España Moderna, Cuadernos de Historia Moderna, Anejos VIII, UCM.

GARCÍA FERNÁNDEZ, M. (1995). Herencia y patrimonio familiar en la Castilla del Antiguo Régimen (1650-1834). Efectos socioeconómicos de la muerte y la partición de bienes. Valladolid: Universidad de Valladolid.

(dir.) (2013). Cultura material y vida cotidiana moderna: Escenarios. Madrid: Sílex.

(2011 -2014-). "La cuestión de un Traje Nacional a finales del siglo XVIII. Demanda, consumo y gestión de la economía familiar". Norba. Revista de Historia, 24, pp. 151-165.

(2015). "Los ropajes populares urbanos recogidos en el Hospital de la Resurrección de Valladolid. Siglo XVIII". En Arias de Saavedra, I. y LópezGuadalupe, M.L. (eds.). Vida cotidiana en la monarquía hispánica. Tiempos y espacios. Granada: Universidad de Granada, pp. 347-367.

y DÁVILA CORONA, R.Ma (2005). "Vestirse y vestir la casa. El consumo de productos textiles en Valladolid (1700-1860)". Obradoiro de Historia Moderna, 14, pp. 141-174.

GARCÍA HURTADO, M.R. (ed.) (2009). Vivir las Luces. La vida cotidiana en la España del siglo XVIII. Madrid: Sílex. 
GARCÍA MERCADAL, J. (1999). Viajes de Extranjeros por España y Portugal (Desde los tiempos más remotos hasta comienzos del siglo XX). Valladolid: Junta de Castilla y León; seis tomos.

LEIRA SÁNCHEZ, A. (2003). El vestido y la moda en tiempos de Goya [recurso electrónico]. Textil e Indumentaria: materias, técnicas y evolución, Facultad de Geografía e Historia de la UCM., pp. 205-219. <http: dialnet.unirioja.es/servlet/libro?código=398393 $>$. (2007). “La moda en España durante el siglo XVIII”. Indumenta, 0, pp. 87-94.

MUÑOZ NAVARRO, D. (ed.) (2011). Comprar, vender y consumir. Nuevas aportaciones a la historia del consumo en la España moderna. Valencia: Universidad de Valencia.

PEÑAFIEL RAMÓN, A. (2006). Los rostros del ocio: paseantes y paseos en la Murcia del Setecientos. Murcia: Universidad de Murcia.

PÉREZ ESTÉVEZ, R.Mª y GONZÁLEZ, R.Ma (1992). Pretendientes y pícaros españoles en Roma. Siglo XVIII. Valladolid: Universidad de Valladolid.

PÉREZ-GARCÍA, M. (2013). Vicarious Consumers. Trans-national meetings between the West and East in the Mediterranean world (1730 - 1808). Farnham: Ashgate.

ROCHE, D. (1997). Histoire des choses banales. Naissance de la consummation dans les sociétés traditionnelles (XVIIe-XIXe siècles). París: Fayard.

RODRÍGUEZ SAN PEDRO-BEZARES, L.E. y SÁNCHEZ LORA, J.L. (2014). Los siglos XVI-XVII: Cultura y vida cotidiana. Madrid: Síntesis.

ROSADO CALATAYUD, L.M. (2016). "Moda, la sociabilidad y nuevos patrones de consumo en el Reino de Valencia en el siglo XVIII. El caso de la ciudad de Xàtiva”. Estudis. Revista de Historia Moderna, 42, pp. 155-176.

SAAVEDRA, P. y SOBRADO, H. (2004). El siglo de las Luces. Cultura y vida cotidiana. Madrid: Síntesis.

SARTI, R. (2003). Vida en familia. Casa, comida y vestido en la Europa Moderna. Barcelona: Crítica. 



\section{VESTIR LOS CUARTOS Y EL CUERPO EN EL CLERO REGULAR MASCULINO: LOS CANÓNIGOS DE SAN ISIDORO DE LEÓN (1700-1825)}

\section{ROOM FURNISHINGS, ROBES AND JEWELLERY OF REGULAR MALE CLERGY: THE CANONS OF SAN ISIDORO LEON (1700- 1825)}

JUAN MANUEL BARTOLOMÉ BARTOLOMÉ

Departamento de Historia, Universidad de León (León)

jmbarb@unileon.es

Recibido: $12 / 09 / 2016$

Aceptado: 26/01/2017

RESUMEN: En el artículo, el objetivo principal es estudiar los bienes y principalmente las condiciones de vida que tienen los canónigos y religiosos de la Real Colegiata de San Isidoro de león, a través del análisis de los textiles que hay en sus cuartos ( ropa de cama y casa) y la ropa y ahajas destinadas a la vestimenta personal. De este modo, se trata de ver las diferencias entre los canónigos, en relación o no con el cargo, y la llegada de nuevas prendas y fibras textiles. Por lo tanto, es un estudio centrado en las condiciones de vida y las pautas de consumo.

Para conseguir los objetivos planteados contamos como principal fuente de información con los inventarios postmortem de los canónigos y religiosos de la Real Colegiata de San Isidoro de león, efectuados a lo largo del siglo XVIII y los veinticinco primeros años del siglo XIX.

PALABRAS CLAVE: Clero regular, canónigos, León, bienes, vida cotidiana, consumo

ABSTRACT: The main objective of this article is to study the goods and living conditions of the canons and religious of the Royal Collegiate Church of San Isidoro de León, analyzing as much their bedding and household linens as their clothes and jewelry. Thus, we have tried to see firstly the differences among the Canons according to their status and secondly the arrival of new garments and textiles. Therefore, this research focuses on living conditions and consumption patterns.

\footnotetext{
${ }^{1}$ Trabajo enmarcado en el Proyecto de Investigación: Civilización, juventud y cultura material e inmaterial. Familia e identidad social. Demandas y apariencias en la Castilla interior. 15001850; HAR2013-48901-C6-3-R; Mineco, Retos: 2014-2017.
} 
In order to achieve these goals, we have used, as the main source of information, postmortem inventories of the canons and religious made throughout the eighteenth century and the first quarter of the nineteenth century in the Collegiate mentioned above.

KEYWORDS: regular clergy, canons, Leon, goods, daily life, consumption

Los estudios sobre el clero regular se han centrado en la Edad Moderna más en los conventos femeninos ${ }^{2}$, aunque no hay que olvidar que se han realizado relevantes análisis sobre los cabildos catedralicios ${ }^{3}$, en cambio los frailes y monjes han recibido poca atención ${ }^{4}$, y lo mismo podemos señalar para los religiosos masculinos- canónigos, profesos, etc.- de instituciones más modestas.

${ }^{2}$ Un interesante repaso, que nos sirve para evitar una exhaustiva cita, lo encontramos en M. REDER GADOWW (2000). "Las voces silenciosas de los claustros de clausura", Cuadernos de Historia Moderna, 25, Madrid, pp. 279-335. Más tarde, una nueva actualización de este tipo de trabajos aparece en F.J. CAMPOS Y FERNÁNDEZ DE SEVILLA (dir.) (2004). La clausura femenina en España. Actas del Simposium, El Escorial; Ma. I. VIFORCOS MARINAS y MaD. CAMPOS SÁNCHEZ-BORDONA (coords.) (2005). Fundadores, fundaciones y espacios de la vida conventual. Nuevas aportaciones al monacato femenino, León; M ${ }^{\mathrm{a}}$. VIFORCOS MARINAS y R. LORENZO LÓPEZ (coords.) (2007). Historias compartidas, Religiosidad y reclusión femenina en España, Portugal y América, Siglos XV-XIX, León. Y para el mundo de las fundaciones de conventos y sus fundadores, A. ATIENZA LÓPEZ (2008). Tiempos de conventos. Una historia social de las fundaciones en la España Moderna, Madrid. En cuanto a los conventos y la vida en los mismos, tenemos las interesantes aportaciones de MáL. SÁNCHEZ HERNÁNDEZ (2009). "Veinticuatro horas en la vida de un monasterio de los siglos XVI y XVII”, Cuadernos de Historia Moderna. Anejos. Anejo VIII, pp.199-227. O. REY CASTELAO (2009). "Las instituciones monásticas femeninas, ¿centros de producción?, Manuscrits, 27, pp. 59-76. M. DE P. PI CORRALES (2010). "Existencia de una monja: vivir el convento, sentir la Reforma (s. XVI-XVIII)", Tiempos Modernos: Revista Electrónica de Historia Moderna. Vol.7. No 20. Á. ATIENZA LÓPEZ (2010). "La vida económica de los conventos femeninos en España durante la Edad Moderna. De una visión general a planteamientos más novedosos", Ariadna, 21, pp. 218-253.

${ }^{3}$ A. CABEZA (1996). Clérigos y Señores. Política y religión en Palencia en el Siglo de Oro, Palencia. A. IRIGOYEN (2001). Entre el cielo y la tierra. Entre la familia y la institución. El cabildo de la catedral de Murcia en el siglo XVIII, Murcia.

${ }^{4}$ M. BARRIO GOZALO (1994). "Los frailes y monjes de la ciudad de Segovia a finales del Antiguo Régimen (1768-1834)", Investigaciones Históricas: Época Moderna y Contemporánea, $\mathrm{N}^{\mathrm{o}} 14$, pp. 87-118.

(2000). "Reforma y supresión de los regulares en España al final del Antiguo Régimen (1759-1836)", Investigaciones Históricas, № 20, pp. 89-118.

(1995). "La vida cotidiana de los monjes jerónimos de Santa María del Parral de Segovia en vísperas de la exclaustración", en Campo, F.J. y Fernández de Sevilla, F. (coord.). Actas del simposium Monjes y monasterios españoles, Vol. 3, pp. 815-832. 
El estudio que presentamos tiene como principal objetivo apreciar los contrastes diferenciales en la posesión de bienes y en las condiciones de vida de los religiosos regulares de San Isidoro de León, centrándonos en la ropa de la casa y la destinada al cuerpo y las alhajas personales. De este modo, se nos plantean varios interrogantes: ¿A pesar de la renuncia previa a los bienes materiales, una vez que ingresan en la orden la posesión de los mismos es uniforme? ¿Existen pautas de consumo diferenciadas, apreciadas en los ámbitos de estudio señalados, vinculadas a los cargos de los canónigos? Se trata, por lo tanto, de un análisis enmarcado en las condiciones de vida y la historia del consumo 5 .

Para conseguir los objetivos planteados contamos como principal fuente de información con los inventarios postmortem de los canónigos y religiosos de la Real Colegiata de San Isidoro de León ${ }^{6}$, efectuados a lo largo del siglo XVIII y los veinticinco primeros años del siglo XIX.

A pesar de que no vamos a adentrarnos en explicitar toda la historia de la Real Casa y Colegiata de San Isidoro de León ${ }^{7}$, sí consideramos oportuno señalar que sus miembros forman parte de los canónigos regulares de San Agustín. Sus primeros estatutos se realizaron en 1555 por Martín de Azpilcueta (doctor Navarro) ${ }^{8}$, el cual fue nombrado visitador de S. Isidoro en el mismo año. Más tarde, en 1579, fueron

\footnotetext{
${ }^{5}$ Dentro de las nuevas tendencias ya mencionadas para el clero regular masculino y sobre todo femenino. Ver aportaciones ya referenciadas de A. ATIENZA y M. DE P. PI CORRALES, donde es importante examinar la vida conventual a partir de la idea de que los conventos no son instituciones ordenadas y organizadas, sino también un espacio de vivencia y convivencia. Y también enmarcado en las líneas de investigación sobre la cultura material, el consumo. Ver Grupo de Investigación coordinado por Máximo García Fernández sobre la familia, consumo, etc., en la Edad Moderna.

${ }^{6}$ Nuestro agradecimiento a los canónigos de la Real Colegiata de San Isidoro de León y en particular a la persona encargada de su archivo histórico, Raquel Jaén, por poner a nuestra disposición la documentación del Archivo Histórico de la Colegiata y habernos facilitado su consulta.

7 E. FERNÁNDEZ GONZÁLEZ (1991). San Isidoro de León, Madrid. J. PÉREZ LLAMAZARES (1927). Historia de la Real Colegiata de San Isidoro de León (Edición facsímil), León. M. VALDÉS FERNÁNDEZ (1979). "El Panteón Real de la Colegiata de San Isidoro de León", Maravillas de la España Medieval: Tesoro sagrado y monarquía, León. 2001. A. VIÑAYO (1971). La Colegiata de San Isidoro, León, Madrid. A. GARCÍA MARTÍNEZ (2005). "Aproximación crítica a la historiografía de San Isidoro de León", Estudios Humanísticos. Historia, № 4, pp. 53-93.

${ }^{8}$ Archivo Capitular de San Isidoro de León ( A.C.S.I.L.), Caja 70
} 
recopilados por el abad, Pedro de Zúñiga y Avellaneda9. En el siglo XVII experimentaron modificaciones, en 1667 Luis Tello Olivares, y pervivieron en el siglo XVIII y primera mitad del siglo XIX.

Lo referente a la realización de los inventarios de bienes de los canónigos en vida y una vez que fallecen y las transmisiones de los mismos, se recogen en los estatutos desde el siglo XVI y su texto casi no experimenta modificaciones significativas. Así, respecto a los bienes y alhajas que poseen se establece, por una parte, que en los diez primeros días de enero de cada año presentarán todos los canónigos un inventario que "exprese todos sus ajuares y haberes, deudas en pro y contra, con las llaves de sus aposentos..." oportuno se hará por el prior y tesorero un inventario de todos sus haberes...y se venderán en almoneda. De su total valor se pagarán las deudas y entierro y se cumplirán sus declaraciones...Después de esto lo que reste de su haber deberá distribuirse en tres porciones iguales: una para el bien de su alma, invirtiéndolo en misas, otra a favor de la fábrica y la tercera entre los canónigos..."11.

No todos los religiosos heredaban por igual, ya que se hacía una distinción entre canónigos, infantes ordenados que recibían tres partes e infantes de blanco, a los que se asignaba la mitad.

También hay que tener presente que los miembros de la comunidad del convento de San Isidoro de León estaba formada no sólo por canónigos - cuyo número oscila entre una media de unos 15 y 16 en el siglo XVIII y 12 en los primeros años del siglo XIX-infantes ordenados - con medias entre 2 y 1 respectivamente- infantes de blanco - con medias superiores a los dos miembros en el setecientos para descender a una media de uno en las primeras décadas del siglo XIX-, sino también por presbíteros un sacristán, un portero- acólitos y finalmente criados domésticos de los canónigos, generalmente una media de un criado por cada uno.

\section{LA COMPOSICIÓN Y DIFERENCIAS EN LOS BIENES Y AJUARES DE LOS RELIGIOSOS}

Antes de abordar este apartado es necesario aclarar dos aspectos de vital importancia: Por un lado, los religiosos regulares normalmente ceden las herencias que

\footnotetext{
${ }^{9}$ Ibidem.

${ }^{10}$ Id., Caja 71.23

${ }^{11}$ Ibidem.
} 
puedan corresponderles de sus padres o parientes a sus propios familiares ${ }^{12}$, a no ser que la comunidad se halle en extrema necesidad ${ }^{13}$. Es más, en los propios estatutos de la Colegiata de San Isidoro se hace referencia a que harán la renuncia de bienes según las condiciones que establece el Concilio de Trento. Y como meros usufructuarios y administradores en comisión de sus peculios o haberes no podrán disponer de ellos por testamento. Sólo podrán declarar aquello que les pareciere bien para tranquilidad de sus conciencias ${ }^{14}$.

De acuerdo con lo expuesto, tendría poco sentido analizar los bienes y ajuares de los canónigos. No obstante, cuando mueren y se realiza el inventario en el mismo se recogen bienes y ajuares que posteriormente se venden en almoneda. Lo cual nos indica que a la hora de renunciar a sus herencias se les permitía “...reservar bienes para el usufructo que les pareciese..."15.

De ahí, que la presencia de inventarios postmortem de canónigos, donde se especifican los bienes que poseen y que son vendidos en almoneda, nos permite, dada la valoración de compra de los objetos, profundizar en el estudio de dichos bienes y alhajas. Los cuales proceden tanto del patrimonio familiar como también de los que van adquiriendo poco a poco en las almonedas de sus compañeros que fallecen.

CUADRO 1. Bienes y alhajas de los Canónigos de San Isidoro (1700-1825) (En reales y porcentajes sobre el valor del stock de bienes inventariados)

\begin{tabular}{|c|c|c|c|c|c|}
\hline Cargo & Data & \% & Líquido & \% & Medias líquido \\
\hline 711.259 & 258.972 & 36,4 & 452.287 & 63,6 & 10.279 \\
\hline
\end{tabular}

Fuente: A.H.C.S.I.: Inventarios postmortem de 44 religiosos

\footnotetext{
${ }^{12}$ Es frecuente en el hermano varón primogénito heredero del vinculo familiar y encargado de perpetuar el linaje y la familia.

A comienzos del siglo XIX, en 1802, el novicio don Juan Isidro Martínez y Cañas, va a ser admitido como canónigo regular y tiene que hacer renuncia previa del patrimonio que tiene o pueda tener, pero solicita al prior que le permita la retención de un legado pío que le dono don Santos Rodríguez, marqués de San Isidro, regidor perpetuo de la ciudad de León, por los días de su vida. A.C.S.I.L., Caja 49-22.

${ }^{13}$ Como ocurre con el monasterio del Parral en algunos años del primer tercio del siglo XIX, en concreto en los inmediatamente posteriores a la primera y segunda exclaustración. M. BARRIO GOZALO, "Los frailes y monjes en la ciudad de Segovia...", p. 100.

${ }^{14}$ A.C.S.I.L., Caja 71

${ }^{15}$ E incluso también algunos legados píos, como el que se solicita por don Juan Isidro Martínez y Cañas, en 1802 .
} 
Del total de los cuarenta y cuatro religiosos que fallecen en el periodo analizado, desde los años 1700 a 1825 , el montante global de los bienes supone la cantidad de 711. 259 reales. Las deudas, el pasivo, debido tanto a las deudas de los difuntos como a las cantidades destinadas a sufragar los gastos del entierro ${ }^{16}$, son muy cuantiosas, ya que con 258.972 reales significan el 36,4\% del cargo de los bienes. De ahí, que el $63,6 \%, 452.287$ reales, es la cantidad que queda líquida y será repartida en tres partes. Lo cual significa que la media de bienes líquidos por canónigos es de 10.279 reales. Indudablemente, es a nivel comparativo una media modesta, sobre todo si la relacionamos con la de los comerciantes y financieros de la ciudad leonesa para el mismo periodo ${ }^{17}$, pero que se aproxima a las de los campesinos provinciales, sobre todo a los bercianos ${ }^{18}$. Además, siguiendo la tónica de otros grupos sociales, incluso del campesinado, las cantidades medias señaladas encubren fuertes contrastes tanto a lo largo del siglo XVIII como en los veinticinco años del siglo XIX.

Ahora bien, en las cantidades que se señalan como cargos a favor de los canónigos se ha de aclarar que se incluyen diversas partidas. Por un lado, están los ingresos que proceden de los bienes semovientes, ganadería, los cuales son más frecuentes que se obtengan en los que además de ser canónigos tienen a su cargo una parroquia en una localidad leonesa o fuera de León. Por otro lado, están los bienes que podemos

${ }^{16}$ A nivel general el resto de los grupos sociales que viven en la Corona de Castilla, según la legislación de las Leyes de Toro de 1505, deberán pagar estos gastos del funeral y misas del líquido que quede libre de los bienes patrimoniales y dentro de lo que se conoce como el quinto de libre disposición.

17 Medias de patrimonios líquidos de cerca de los 500.000 reales para los comerciantes y superiores a los 800.000 para los que unían a las funciones comerciales las financieras. J.M. BARTOLOMÉ BARTOLOMÉ (2009). Familias de comerciantes y financieros de la ciudad de León (1700-1850), León.

18 Las familias campesinas terracampinas de Sahagún y vitícolas de El Bierzo poseen patrimonios por debajo de los 10.000 reales, 9.863 y 8.671 respectivamente. Y los más elevados de la vega baja del Esla se sitúan en 13.838. J.M. BARTOLOMÉ BARTOLOMÉ (1996). Vino y viticultores en El Bierzo. Sociedad y estructuras económicas durante el siglo XVIII León.

(2004). "Condiciones de vida y privacidad cotidiana del campesinado leonés de Tierra de Campos: La comarca de Sahagún en el siglo XVIII”, Estudios Humanísticos. Historia, N³, pp. 37-51.

(2004). “Condiciones de vida y pautas de consumo del campesinado leonés de La Bañeza y Astorga (1750-1850)", en El mundo rural en la España Moderna. Actas de la VII ${ }^{a}$ Reunión Científica de la Fundación Española de Historia Moderna, Cuenca, pp. 589-590.

J.M. PÉREZ GARCÍA (1998). Un modelo social leonés en crecimiento: la vega baja del Esla entre 1700 y 1850 , León. 
englobar en mobiliarios, desde aperos y útiles de labranza hasta fibras textiles y productos agrarios y de la despensa, sin olvidar los más relevantes conectados con el dinero, alhajas, mobiliario de la casa, vestimenta del cuerpo y de la casa, etc. Y finalmente, están las cantidades que les corresponden por la Plana de Misa de Alba, las cuales son generalmente en cereales que se venden, por la Plana de la Mesa Capitular ${ }^{19}$, es decir por las rentas que genera la Colegiata, y las deudas a favor del difunto que se consiguen cobrar de forma más o menos rápida. De este modo, sí nos es posible calcular que casi la mitad de las cantidades que figuran como cargos a favor, el $44,3 \%$, son las que provienen del último aspecto señalado: deudas a favor y Plana de la Misa de Alba fundamentalmente ${ }^{20}$.

Por lo tanto, si exceptuamos a los canónigos que a su vez detentan un cargo parroquial, las cantidades que proceden de las Planas de la Colegiata, sobre todo de las fanegas de cereal que se reparten y venden a cada religioso, y los pequeños repartos hereditarios de los hermanos fallecidos, a los que se añadirán los estipendios por misas, son los únicos ingresos monetarios de que disponen para poder adquirir bienes y alhajas. Sin embargo, la imagen de sus bienes es más polarizada, lo cual nos lleva a considerar que cuando se produce la profesión no renuncian a todos los bienes y podían conservar, tal como ya se ha señalado, algunos para su usufructo. Es la única explicación que encontramos a la manifiesta diversidad de lo que se denominan sus activos o cargos.

Cuadro 2. Estructuras de los bienes y alhajas de los cargos (1700-1825) (En reales y porcentajes sobre el valor del stock de bienes inventariados)

\begin{tabular}{|l|c|c|}
\cline { 2 - 3 } \multicolumn{1}{c|}{} & Cantidades & $\mathbf{\%}$ \\
\hline Ganadería & 12.487 & 1,7 \\
\hline Riqueza mobiliaria & 384.481 & 54,0 \\
\hline Plana misa alba, deudas a favor, etc. & 314.290 & 44,3 \\
\hline
\end{tabular}

Fuente: A.H.C.S.I.: Inventarios postmortem de 44 religiosos.

A su vez las rentas provenientes de los beneficios parroquiales, donde no hay que olvidar la importante parte diezmal, junto con la propia producción de las tierras ${ }^{21}$, generan unos excedentes productivos muy interesantes. De este modo, si realizamos el análisis de la estructura de la riqueza mobiliaria, los

\footnotetext{
${ }^{19}$ Aparece más en los años veinte del siglo XIX.

${ }^{20}$ La cantidad es de 314.291 reales. A.C.S.I.L.

${ }^{21}$ Tal como lo demuestra la presencia de útiles de labranza- carros, trillos, etc.- Ibidem.
} 
384.481 reales que suponían el $54 \%$ de los activos de bienes, los productos agrarios vendidos, sobre todo cereales y vino, llegan a suponer un 3,9\% del total del dinero obtenido de los bienes mobiliarios ${ }^{22}$. Los productos que podemos considerar de la despensa- garbanzos, perniles, cecina, tocino, harina, manteca, etc.eran también más abundantes en los canónigos que estaban al frente de una parroquia. Lo cual en parte resulta lógico dada su mayor posibilidad de acceder a la mayor parte de los mismos. No obstante, había artículos como el tabaco y el más extendido chocolate donde no se aprecian esas diferencias, ya que en el caso del chocolate es un consumo muy generalizado y más entre los canónigos que residían en la Real Colegiata de León. En total, este tipo de productos de la despensa son vendidos en 384.481 reales, lo que significa un $3,5 \%$ de la riqueza mobiliaria. La misma tendencia se observa en las fibras y piezas textiles, un 2,6\% de la riqueza mobiliaria, donde predominan las de lienzo, lana, y sólo de forma muy testimonial figurará ya el algodón, avanzado el siglo XVIII' ${ }^{23}$.

\section{CUADRO 3. Estructura riqueza mobiliaria Canónicos San Isidoro (1700-1825)}

(En reales y porcentajes sobre el valor del stock de bienes inventariados)

\begin{tabular}{|l|c|c|}
\cline { 2 - 3 } \multicolumn{1}{c|}{} & Cantidades & \% \\
\hline Cereales y vino & 14.912 & 3,9 \\
\hline Útiles labranza & 1.423 & 0,3 \\
\hline Fibras y piezas textiles & 9.894 & 2,6 \\
\hline Productos de la despensa & 13.357 & 3,5 \\
\hline Dinero líquido & 95.551 & 24,8 \\
\hline Deudas a favor & 37.862 & 9,9 \\
\hline Ajuar, mobiliario, etc. & 211.482 & 55,0 \\
\hline
\end{tabular}

Fuente: A.H.C.S.I.: Inventarios postmortem de 44 religiosos.

En las deudas a favor y particularmente en el dinero líquido que poseen los religiosos, lo cual con la cantidad global de 95.551 reales supone el $24,8 \%$ de la riqueza mobiliaria, no se aprecian tantas diferencias entre los que están al cargo de una rectoría y los que únicamente profesan como canónigos de la Colegiata. Así, serán los segundos

${ }^{22}$ La cantidad es de 14.912 reales, destacando de nuevo a don Manuel González que tiene de mosto 546 cántaras, de las cuales 516 son las que proceden del diezmo y las restantes de la viña de la rectoría. Y de vino hay 570 cántaras y media. En total se consiguieron 3.158 reales. Ibidem.

${ }^{23}$ Don Benito Villafañe cuando fallece en 1776 posee piezas de cotonia por las que se obtienen 48 reales. Ibidem. 
los que tengan más dinero contante en los instantes de su fallecimiento ${ }^{24}$, pero $\sin$ olvidar la posición relevante de los priores de parroquias ${ }^{25}$.

En definitiva, los contrastes en las cantidades globales de los bienes de los canónigos de la Colegiata de San Isidoro están muy relacionados con el desempeño de la función de priores de parroquias que dependen de la Colegiata. Su mayor acceso a los diezmos y a la producción agraria provoca los desequilibrios analizados, hasta el punto de comportarse más como párrocos que como religiosos regulares ${ }^{26}$.

\section{LOS CONTRASTES EN LAS CONDICIONES DE VIDA: LA ROPA Y LAS ALHAJAS}

Los bienes que conforman las condiciones o estilo de vida ${ }^{27}$ a nivel cuantitativo son muy relevantes, ya que con un total de 211.482 reales suponen un poco más de la mitad, el $55 \%$, de la riqueza mobiliaria. Los valores medios por religioso experimentarán una tendencia al crecimiento durante el periodo analizado. Así, pasarán de 3.975 reales en la primera mitad del siglo XVIII a 6.218 reales en la segunda mitad y a 4.392 reales en los años $1800-1825^{28}$. Mejoría muy significativa en el periodo

${ }^{24}$ Como don Francisco Canseco Robles, en 1736, que dispondrá monedas de oro y plata por valor de 9.916 reales. O el prior don Juan Álvarez Carballo, en 1746, con 4.7774 reales. O el canónigo jubilado, Don Francisco Antonio Gómez de Caso, que muere en 1798, con 7.720 reales. Ibidem.

${ }^{25}$ Don Juan de Llanos, canónigo y prior de Santa María de Villalpando, en Zamora, en 1748 tiene 5.562 reales de dinero contante. Ibidem.

${ }^{26}$ Según Maximiliano Barrio, los conceptos que componen los ingresos del clero parroquial en España en la Edad Moderna son de tres tipos: rentas de propiedades muebles e inmuebles, frutos decimales e ingresos adventicios. Todos se benefician del producto de algunos bienes inmuebles, tierras, casas, pero el autor mencionado no hace referencia a la explotación de la ganadería. M. BARRIO GOZALO (2007). "El clero parroquial en la España Moderna. Estilo de vida y aspectos socieconómicos", Cuadernos de Investigación Histórica, № 24, Madrid, pp. 328-330.

${ }^{27}$ Dichos bienes los podemos agrupar en mobiliario de la casa, útiles de cocina, ropa personal, ropa cama, ropa casa, objetos de decoración de la casa, libros y alhajas, objetos de oro y plata, de cubertería y uso personal

${ }^{28}$ A nivel comparativo, los campesinos de Sahagún tienen unas medias para el siglo XVIII de 839 reales, los del el Bierzo Bajo de 744 reales y las más altas de la Vega Baja del Esla, más de 1.200 reales, y las superiores de La Bañeza y Astorga, 3.000 reales, son todavía inferiores a las de los religiosos de San Isidoro. Ver J.M. BARTOLOMÉ BARTOLOMÉ (1996). Vino y viticultores en El Bierzo....

(2004). "Condiciones de vida y privacidad cotidiana...".

(2004). "Condiciones de vida y pautas de consumo del campesinado...". 
1750-1799 explicable también en parte por la tendencia inflacionista de dichos años.

No obstante, existen desequilibrios en los bienes y alhajas, de ahí que, tal como hemos señalado en los objetivos, lo que más nos preocupa es el análisis de las diferencias en los textiles de la casa y personales y los objetos de adorno, en el caso de que existan, conectados con el rango o categoría dentro del convento: priores, canónigos, canónigos y párrocos o priores de parroquias. Sin obviar la tendencia evolutiva del periodo objeto del estudio.

Los canónigos son los predominantes a nivel numérico y los que dan sentido a la comunidad religiosa. A nivel cuantitativo se aprecia una mejoría en los valores medios según avanza el siglo XVIII, segunda mitad, y los veinticinco primeros años del XIX. De este modo, si en la primera mitad del siglo XVIII tan solo tres canónigos de 19, un $15,7 \%$, se situaban por encima de la media ya señalada de 3.975 reales, en la segunda mitad del siglo el porcentaje sube a un 66,7\% y en los años de $1800-1825$ a un 50\%.

Por lo tanto, esta primera aproximación sí nos habla de valores de los objetos de las condiciones y estilo de vida en progresión en el periodo estudiado, con una incidencia poco perceptible de la crisis económica finisecular y de los primeros años del siglo XIX.

Entre los que se situaban en esta posición de ventaja estaba el canónigo don Luis de Sosa, que cuando fallece, en 1744, se le inventarían bienes por valor de 27.140 reales y los que conformaban las condiciones de vida son vendidos en almoneda en 5.622 reales $^{29}$. Es interesante la descripción de las dependencias de las que dispone para su vivir diario. Lejos de la simple celda nos encontramos con un cuarto amplio, que tiene una sala, una alcoba y un estudio incorporado y cuartos altos. Se trataría en el primer caso de espacios conectados, típicos del Antiguo Régimen ${ }^{30}$. En la alcoba hay una cama de nogal y una tarima con cordeles, con colchones y ropa para cubrirlas: cuatro colchones, dos de terliz y dos de lienzo; cuatro colchas, una afelpada, otra de

J.M. PÉREZ GARCÍA (1998). Un modelo social leonés en crecimiento...

${ }^{29}$ A.C.S.I.L., Caja $47-11$

30 Lo normal es que las habitaciones, siguiendo las casas y palacios del Renacimiento, estuviesen comunicadas entre sí de modo que no se podía pasar de una a otra sin atravesar las que había en medio. Entonces para facilitar los desplazamientos había que hacer muchas puertas. Lo sensato es disponer las puertas que permitan llegar al mayor número de sitios del edificio, escribió León Battista Alberti, SARTI, R., Vida en familia. Casa, comida y vestido en la Europa Moderna, Barcelona, 2002, pp.178-179. 
lienzo pintado, otra manchega y la gran novedad de cotonia ${ }^{31}$; cobertores; dos mantas de Palencia; sábanas, nueve de lienzo y cuatro de estopa; almohadas: cuatro ${ }^{32}$. Entre los muebles destinados a la lectura y el estudio destaca un escritorio de nogal con sus navetas, en las que se custodiaba lo de más valor, como los relicarios, los papeles familiares, el dinero y las alhajas de oro y plata, principalmente cubiertos, cucharas de plata, más que personales ${ }^{33}$. En los cuartos altos, destinados posiblemente a los criados personales, hay muebles para dormir o descansar: una tarima con dos colchones (uno de terliz y el otro de lienzo) y una cama rasa con un colchón y un jergón; con ropa de cama: dos mantas y una sobrecama de paño azul ${ }^{34}$.

En la decoración de la sala, con su alcoba y estudio, hay cuadros de medio cuerpo, un espejo vendido en 50 reales, dos doseles, el uno con un crucifijo y una lámina, cuatro láminas y tres países, un reloj que señalan como propiedad de su sobrino y cortinas, de estopa, de bayeta verde, bordadas, adjudicadas todas en 55 reales $^{35}$. Indudablemente, es difícil conocer, tal como ser realiza el inventario postmortem, si estos objetos decorativos estaban almacenados en los cofres, o si realmente se utilizaban para decorar las estancias, aunque los cuadros dados su tamaño y los doseles es más fácil que estuviesen a la vista que encerrados en arcones.

También posee ropa de casa, paños de manos, tablas de manteles, servilletas, adquirida en un total de 302 reales $^{36}$ y ropa destinada a vestir el cuerpo, distinta a la religiosa. De este modo, abundarán las medias, preferentemente de lana, calzoncillos, calcetas, camisas, guardapiés, armadores, y hasta una capa de paño de Ávila ${ }^{37}$, un capote forrado en sempiterna, y las nuevas prendas típicas del siglo XVIII y de

${ }^{31}$ Elaborada con la nueva materia prima textil más innovadora y barata: algodón. A.C.S.I.L., Caja 47-11

${ }^{32}$ Hay que tener en cuenta que la ropa de cama, incluidos los colchones, que hay en sus dependencias y que se vendieron en almoneda suponen la cantidad más elevada, con 1.541 reales, de todos los bienes que conforman las condiciones de vida. Ibidem.

${ }^{33}$ Solo encontramos relicarios y escapularios vendidos en almoneda en 143 reales. Es llamativo que entre estos objetos de valor se guarde también un poco de algodón. Ibidem.

${ }^{34}$ Desconocemos si los materiales como el carbón y la leña eran para el uso de la comunidad o bien individual del canónigo para calentar sus dependencias. Y el pellejo de carnero nos ha parecido digno de mención debido a un uso que pudiera ser alimenticio propio o de venta de la piel, lo cual nos resulta más extraño.

${ }^{35}$ A.C.S.I.L., Caja 47-11

${ }^{36}$ Ibidem

37 Esta prenda tan tradicional se resiste a desaparecer. C. BERNIS MADRAZO (1956). Indumentaria española en tiempos de Carlos $V$, Madrid, CSIC. 
influencia francesa: tres chupas - dos de paño y una de bayeta- y una casaca militar de carro de oro $^{38}$. En este sentido, no hay que olvidar que la ropa personal constituye en cuanto a la almoneda la segunda partida de reales recibidos más elevada, solo por debajo de la ropa de cama, con 1.047 reales.

En fin, unas condiciones de vida muy próximas a los campesinos leoneses más prósperos en sus riqueza patrimonial ${ }^{39}$, con ropa, sobre todo personal, que llama la atención por la novedad de las piezas, acercándonos a los comerciantes y regidores de la ciudad leonesa ${ }^{40}$.

Ahora bien, ¿se repite este mismo esquema apreciado en las familias campesinas leonesas en los canónigos con menos patrimonios? Para ello, hemos elegido a uno de los canónigos con un patrimonio más modesto. Muy por debajo de la media señalada. Se trata de don Juan de Robles Falconi, cuyo inventario postomortem se realiza a comienzos del siglo XVIII, 1704, y con una valoración de solo 4.005 reales $^{41}$, provenientes la mitad, 2.015 reales, de la almoneda de sus bienes mobiliarios ${ }^{42}$. Aun así, los bienes relacionados con las condiciones de vida, 2.001 reales, son elevados ${ }^{43}$. De nuevo las estancias son muy similares al caso anterior: el cuarto donde vivió dispone de alcoba, cuarto de estudio, sala principal y cocinilla. En la sala principal, el mobiliario es más simple, pero la decoración, a base de cuadros y sobre todo de láminas y estampas, de temática religiosa, es muy abundante ${ }^{44}$. Tampoco falta un Eccehomo

\footnotetext{
${ }^{38}$ En el siglo XVIII se fue imponiendo en la vestimenta sobre todo masculina lo que se conoció como "vestido militar" o más la denominación más frecuente de "vestido a la francesa". Era un atuendo institucionalizado en Versalles por Luis XIV y que se componía de casaca, chupa y calzón. A. GIORGI (2015), "La influencia de lo extranjero", en J. Ruiz Ibánez, El Greco y los otros, Albacete, pp. 364-379.

${ }^{39}$ En la comarca terracampina de Sahagún con patrimonios superiores a los 20.000 reales. J.M. BARTOLOMÉ BARTOLOMÉ (2004). “Condiciones de vida y privacidad cotidiana...".

${ }^{40}$ J.M. BARTOLOMÉ BARTOLOMÉ (2009). Familias de comerciantes y financieros de la ciudad de León (1700-1850), León.

${ }^{41}$ Patrimonio muy inferior a los campesinos leones, incluso a los más pobres de El Bierzo Bajo, situados en una media de 8.751 reales. J.M. BARTOLOMÉ BARTOLOMÉ (1996). Vino y viticultores en El Bierzo...

${ }^{42}$ El resto proceden del cereal vendido, 1.432 reales, las limosnas por las misas celebradas, 162 reales, los repartimientos de almonedas, 378 reales y lo que le deben por el vino vendido, 18 reales. A.C.S.I.L., Caja 46-2.

${ }^{43}$ Por encima de las medias ya señaladas de los campesinos leones, exceptuando los de La Bañeza y Astorga.

${ }^{44}$ Se han contabilizado un total de 24, y hay una de la Reina y otra del Rey de España. A.C.S.I.L., Caja 46-2.
} 
de medio cuerpo y una cruz grande de San Toribio de Liébana. Y únicamente habrá una cortina con cenefa de bayeta encarnada de Palencia ${ }^{45}$. En definitiva, una estancia muy sencilla y acorde con el recogimiento espiritual del canónigo. La alcoba sigue la misma línea señalada: una cama con dos colchones, un jergón y dos mantas y como adorno tan solo una cruz colgada en la pared. El cuarto de estudio reúne objetos más variados, con una mesa vieja que tiene un cajón nuevo con siete senos donde se guardan diferentes baratijas "que por ser muy menudas no se expresan" ${ }^{46}$, un arca y un cofre viejo, donde se almacena la ropa de cama y sobre todo la personal. Dos cortinas de bayeta encarnada con su cenefa y varillas es el único objeto decorativo. Finalmente, también habrá un cuarto en el desván destinado al criado del religioso, con una cama, con un jergón y una manta vieja. Por lo tanto, espacios en los que se desarrolla la vida íntima cotidiana similares a los del anterior canónigo, pero con un mobiliario y una decoración más sencilla. No obstante, en el caso de don Juan de Robles los ingresos mayores de sus bienes son los que proceden de la venta en almoneda de su ropa personal, donde las diferencias en los valores son más cercanas a las de don Luis de Sosa. Así, la vestimenta destinada a cubrir el cuerpo, interna y externa, se venderá en 867 reales y en don Luis en 1.049 reales. Entre la misma junto a la religiosa -lobas, mucetas- también aparecerán las casacas y sobre todo las chupas, en total cuatro ${ }^{47}$. Lo que no habrá, tal como se ha señalado, son joyas o alhajas personales, como tampoco piezas de cubertería.

En definitiva, al igual que sucedía con los demás grupos sociales leoneses, los contrastes en las condiciones de vida entre los canónigos en la primera mitad del siglo XVIII son evidentes. Además guardan también correspondencia directa con los niveles globales de sus bienes. No obstante, en la ropa de casa y sobre todo en la personal las diferencias las hallamos más en la cuantía y la calidad de las prendas que en la llegada de novedades.

Aunque en la segunda mitad del siglo XVIII se produce una mejoría general en las cantidades de los bienes de las condiciones de vida, sin embargo, de nuevo es apreciable la falta de uniformidad. De este modo, en el extremo superior se situaría don Francisco Díez de Pobladura, el cual cuando fallece en 1789 posee bienes que son

\footnotetext{
${ }^{45}$ Ibidem.

${ }^{46}$ Ibidem.

${ }^{47}$ Una de Damasco, otra de droguete, otra de ante bordada y una de raso de flores con mangas forrada en tafetán. A.C.S.I.L., Caja 46-2.
} 
vendidos en almoneda por valor de 9.612 reales $^{48}$. Y en el escalón más bajo tenemos a don Benito Robles Monterroso, en 1799, con tal solo 2.436 reales $^{49}$. El montante global de todos sus bienes también guarda correspondencia, ya que en el primer caso son 24.688 reales y en el segundo únicamente 2.907 reales. Estos contrastes vuelven a aparecer principalmente en la ropa y las alhajas personales que poseen. Así, por la ropa de cama de don Francisco se consiguen 1.543 reales, por la de casa 399 reales y por la personal 3.474 reales; y en don Benito respectivamente: 504 reales, 147 y 1.060 reales. Y por las joyas y alhajas personales 378 reales y 0 reales. De ahí, que los dos catres situados en la alcoba donde murió don Francisco y en la sala, estén cubiertos con tres colchones cada uno, y se disponga de tres cobertores de lana, dos mantas, tres colchas blancas afelpadas, catorce sábanas, nueve almohadas. Y en el cuarto alto aparezcan guardados en un baúl otros cuatro cobertores de Palencia, dos viejos y dos nuevos. Llama la atención la abundancia de colchones, sábanas y almohadas. Al contrario don Benito Robles solo tendrá un catre, con dos colchones, dos jergones de terliz ordinarios, dos cobertores, dos colchas -una de lana manchega y otra de hilo- y tres sábanas de lienzo. Es decir, menos piezas y de calidad más inferior tanto en las prendas, caso de los jergones, como en las fibras textiles para su elaboración: lino y sus derivados. En la ropa de casa -manteles, paños de manos, servilletas, paños de afeitar, etc.- sucede lo mismo, la cantidad de piezas es mayor en don Francisco -diez paños de manos y solo uno en don Benito-, pero también en el primer caso se aprecian novedades: quince servilletas y tres toallas. $\mathrm{Y}$ en las cortinas frente a una única de bayeta verde que decora el cuarto principal y alcoba de don Benito, don Francisco tendrá una verde y dos de algodón en la alcoba y otra en la sala.

En la ropa personal las diferencias vienen marcadas fundamentalmente por la mayor cuantía de las piezas y en cierta medida por la calidad de las fibras de las mismas y no tanto por su novedad. No hay que olvidar que la ropa destinada a vestir el cuerpo en don Benito es vendida en almoneda en la cantidad elevada de 1.060 reales, la más alta de todas las que conforman las condiciones de vida, y que entre la misma hay una tradicional capa de paño negro, pero también una casaca, dos chupas, cuatro chupines, tres calzones y como gran novedad tres chalecos. Además, también aparece el algodón, la pana, como fibra de uno de los calzones ${ }^{50}$. El ropero de su compañero le superará en el número de prendas y la mayor variedad de las mismas, sobre todo las consideradas

\footnotetext{
${ }^{48}$ Ibidem, 49-7

${ }^{49}$ Ibidem, 49-18

${ }^{50}$ Ibidem, 49-18
} 
tradicionales y propias de su estado religioso ${ }^{51}$, pero las novedades irán en la línea ya señalada: tres calzones de pana azul, una almilla de cotonia, dos chalecos, uno de bayetón morado y otro de paño forrado en felpa azul, e incluso llama la atención la presencia de "un cabriolé de paño de Tarrasa" 52 . Finalmente, también las alhajas o joyas personales marcan una pequeña diferencia, perceptible en el juego de hebillas de plata y en los curiosos dos anteojos con cercillo de plata de don Francisco, comprados unos por el Señor Prior de San Isidoro por 42 reales $^{53}$.

A comienzos del siglo XIX, años 1800-1825, se produce a nivel cuantitativo un empeoramiento de las condiciones de vida de los canónigos, cuyas medias caen a 4.392 reales. Indudablemente, el convento de San Isidoro sufrió también las crisis de estos convulsos y conflictivos años de finales del Antiguo Régimen, unido a medidas políticas que perjudicaban su patrimonio e intereses: como las desamortizaciones, etc. Un buen ejemplo, es el del canónigo don Apolinario Rodríguez, que fallece en 1824 y en el mismo año se procede a realizar la "almoneda secreta" de sus bienes ${ }^{54}$. El valor global de éstos es bajo: 18.418 reales, pero aún es más inferior el relacionado con las condiciones de vida: únicamente 1.285 reales, muy por debajo de la media. No obstante, la ropa de cama, con 311 reales y la personal, con 555 reales, son las que consiguen tener mayor valoración, muy por encima del mobiliario con 85 reales $^{55}$. De nuevo se apreciará la llegada de novedades en las prendas más conectadas con el cuerpo: un sombrero, vendido en la elevada cantidad de 42 reales, un frac, un pantalón de punto adquirido por el canónigo Canseco en 6 reales y unos guantes por el canónigo

\footnotetext{
${ }^{51}$ Sobresale un balandrán de San Fernando vendido en 290 reales. Ibidem, 49-7.

52 El cabriolet es una prenda de origen extranjero, estaba formada por una capa con aberturas laterales que los hombres vestían para los paseos en carroza, y que se puso de moda en el siglo XVIII, encontrándola también en las familias nobles y de comerciantes de la ciudad de León. M. TEJADA FERNÁNDEZ (2006). Glosario de términos de indumentaria regia y cortesana en España. Siglos XVII y XVIII, Málaga, pp. 417-418.

${ }^{53}$ A.R.C.S.I., 49-7.

${ }^{54}$ La "almoneda secreta", generalmente anterior a la pública y reservada a los religiosos de la Colegiata, se realiza a partir de los años noventa del siglo XVIII y dura hasta 1824 . Son años de dificultades que afectan al clero regular y de ahí podría venir lo de la secreta, para impedir que los objetos de mayor calidad sean adquiridos por personas no vinculadas a la Colegiata. No obstante, somos conscientes que esta afirmación requiere un estudio más riguroso, que escapa a los objetivos planteados en este trabajo. A. R.C.S.I., 49-10.

${ }^{55}$ Ibidem.
} 
Arias en 4 reales ${ }^{56}$. En fin, pocas prendas pero relacionadas con las modas burguesas ${ }^{57}$.

La categoría superior la encontramos en los priores de la Colegiata de San Isidoro. Únicamente disponemos de dos ejemplos, localizados a mediados del siglo XVIII, 1746 y 1756. El primero es el don Juan Álvarez Carballo ${ }^{58}$ y el segundo el de don José Alonso. Los bienes globales, según los inventarios postmortem, se sitúan entre 16.523 de don Juan y los 19.528 de don José, pero los vendidos en la almoneda y relacionados con las condiciones de vida, son ya más similares: 5.184 reales del primero y 5.711 reales del segundo. Lógicamente están por encima, sobre todo en don Juan, de las medias establecidas para todos los canónigos del convento. Sin embargo, las diferencias entre ellos serán menores a las apreciadas para los canónigos. Así, fijándonos de nuevo en la ropa de casa y vestimenta y alhajas personales, apreciamos como en los dos casos las cantidades conseguidas en la almoneda por la venta de las prendas textiles son las más cuantiosas de todos los objetos relacionados con las condiciones de vida. Y dentro de las mismas sobresale en el primer prior la ropa personal, con un total de 1.627 reales, y en el segundo la ropa de la cama con 1.824 reales. Así, en don Juan abundan más que la capas, solo hay una de paño, los armadores, las casacas - una de paño y otra de barragán-, las chupas - dos de paño negro y una de calamaco-, calzones de paño; junto con almillas, medias, etc., y la ropa propiamente religiosa: alzacuellos, mucetas, roquetes, etc. Es decir, novedades francesas junto a prendas tradicionales, pero con ausencia de piezas y fibras textiles más novedosas ${ }^{59}$. Don José dispondrá de un ropero similar, pero dada su afición a montar a caballo tendrá unas botas de montar con una espuela y un redingote, vendido en la elevada cantidad de 102 reales $^{60}$. La ropa de la cama y la casa en los dos priores

\footnotetext{
${ }^{56}$ Ibidem.

${ }^{57} \mathrm{El}$ frac de origen inglés, que pasó antes de llegar a España por el filtro francés, es una prenda refinada que ya aparece en la burguesía mercantil de Santander y leonesa. R. MARURI VILLANUEVA (1999). "Vestir el cuerpo, vestir la casa. El consumo de textiles en la burguesía mercantil de Santander, 1700-1850", en Torras, J. y Yun, B. (Dir.): Consumo, condiciones de vida..., p. 164. J.M. BARTOLOMÉ BARTOLOMÉ (2015). "Consumo y apariencias externas de las familias de la burguesía leonesa (1700-1850)”, Studia Histórica, No 37, pp. 269-290.

58 A.R.C.S.I., 47-13 y 47-49.

${ }^{59}$ Solo en una de las gavetas se hará referencia a un poco de algodón. Id., 47-13.

${ }^{60}$ Fue fomentado por Carlos III en los momentos previos al Motín de Esquilache, en 1766. Era un casacón de origen inglés que llamando riding-coat se difundió a finales de los años veinte en Francia donde pasó a denominarse redingote y de ahí a la corte de Felipe V. M. GARCÍA FERNÁNDEZ (2005)."La presencia de productos textiles con denominación de origen francés e inglés en Castilla. Evolución de los intercambios comerciales entre la Paz de Utrecht y
} 
será abundante, sobre todo la destinada a cubrir la cama. Así, junto a los numerosos colchones, cuatro en las camas respectivas donde fallecieron, hay mantas, una de Palencia nueva en don Juan, cobertores, colchas y también muchas almohadas: trece en don Juan y diecisiete en don José. No faltarán las tablas de manteles, los paños de manos y las servilletas: doce en don Juan, de las cuales dos son nuevas portuguesas. Tampoco notamos contrastes significativos ni en las cortinas -siguen predominando las de bayeta, de color verde para el cuarto donde murió don Juan y sin especificar el color para el cuarto y la sala de don José- ni en las joyas y alhajas personales, inexistentes en don José y de tan solo dos medallas de plata y una cruz en don Juan ${ }^{61}$.

En definitiva, no apreciamos en los aspectos analizados, relacionados con las condiciones de vida, una diferencia clara de un nivel superior de los priores respecto a los canónigos de San Isidoro. En este caso a mayor cargo no hay una mayor tendencia a la comodidad y al consumo. Su diversidad, aunque solo contamos con dos casos, tampoco será tan intensa, pero no hay que olvidar que también estarán abiertos a las novedades y más si éstas vienen en la prendas de la ropa personal.

Una tercera categoría dentro de los religiosos son los que además de canónigos son también curas o priores de alguna parroquia. Como ya se ha analizado son los que en general poseen un mayor nivel en los bienes totales, pero no sucede lo mismo en los bienes que conforman las condiciones de vida, ya que en el siglo XVIII todos a excepción de dos casos están por debajo de las medias señaladas. Uno se corresponde con la primera mitad donde la media era de 3.975 reales, y otro con la segunda mitad donde la media se situaba en 6.218 reales. Sus condiciones de vida a nivel cuantitativo no guardan relación con sus bienes totales y son inferiores a los canónigos que permanecen en la Colegiata leonesa. Ahora bien, ¿esta menor cuantía de objetos relacionados con las condiciones de vida se produce también en el tipo de prendas y la llegada de novedades? O en otras palabras ¿estos canónigos con cargos parroquiales se comportan más en su vida cotidiana como los canónigos de la Colegiata leonesa o como párrocos rurales? Indudablemente, al igual que veíamos con los canónigos residentes en la Colegiata leonesa existe una diversidad entre los canónigos- curas o priores. Así, en la primera mitad del siglo XVIII don Juan de Llanos, canónigo y prior de Santa María de la villa de Villalpando, cuando fallece en 1748, sus bienes globales serán valorados en 27.341 reales y los relacionados con sus condiciones de vida son

Trafalgar”, en A. Guimerá Ravina y V. Peralta Ruiz (coords.). El equilibrio de los imperios: de Utrecht y Trafalgar, Madrid, pp. 277-294.

${ }^{61}$ A.R.C.S.I., 47-13 
vendidos en almoneda en la elevada cifra de 6.700 reales. De ellos los textiles suponen más de la mitad, con 3.577 reales, destacando la ropa personal con 2.054 reales $^{62}$. En el otro extremo se sitúa don Agustín de Caso, canónigo y cura de la villa de Juarilla, que fallece en 1720, con tan solo 9.4503 reales de bienes globales y 2.281 de objetos vinculados con las condiciones de vida, correspondiendo casi la mitad también a los textiles, 1.033 reales, y sobre todo a la ropa personal, con 679 reales $^{63}$. Es decir, la tendencia es la misma y al igual que sucedía con los canónigos residentes en la Colegiata los contrastes son más debido a la cantidad de los objetos que a la variedad de los mismos. Y donde más se va a manifestar es en las prendas de la vestimenta personal. De este modo, don Agustín en su ropero tendrá las que ya hemos visto en el resto de los canónigos y similares a las de don Juan de Llanos, pero en menor cuantía. Es decir, una capa de paño de Segovia; chupas - tres, una de paño Segovia, otro de Damasco y otra de droguete- casacas - una de paño de Segovia, buena forrada en sempiterna- ${ }^{64}$. Solo hay una prenda que sobresale y digna de mencionar en don Juan de Llanos, un redingote, vendido en almoneda en 32 reales $^{65}$.

Según avanza el siglo XVIII, e incluso en los primeros años del XIX, los comportamientos serán muy parecidos a los descritos. El canónigo y prior de San Nicolás de la villa de Villalpando, don Manuel Tascón, cuando se realiza su inventario, tras su fallecimiento en los años setenta del siglo XVIII, tendrá bienes escasos, tan solo valorados en 1.264 reales, de los cuales la casi totalidad son de objetos relacionados con las condiciones de vida y vendidos en almoneda ${ }^{66}$. Sin embargo, en su ropero hay una capa de paño, pero sobre todo chupas (tres), casacas (dos), calzones (tres), un cabriolet y como novedad seis chalecos ${ }^{67}$. Años más tarde, en 1792, el canónigo que ha ocupado el mismo puesto, prior de San Nicolás, don Francisco Hermosa, dispondrá de una mayor cuantía total de bienes, 46.093 reales y también serán más abundantes los relacionados con las condiciones de vida, vendidos en 7.990 reales, por encima de la media del periodo. Los textiles son los que aportan la mayor cantidad con 5.375 reales y la ropa personal es la de mayor valor con 2.835 reales. Indudablemente, habrá

\footnotetext{
${ }^{62}$ Id., 47-17.

${ }^{63}$ Id., 46-10.

${ }^{64}$ Ibidem.

${ }^{65}$ Pero hay que precisar que la fecha del inventario postmortem también es más tardía, 1743. Id., 47-17.

${ }^{66}$ Id., $48-47$.

${ }^{67}$ Ibidem.
} 
más piezas para cubrir las camas -sábanas, cobertores, mantas, almohadas, etc. ${ }^{68}{ }_{-}, \mathrm{y}$ más paños de manos, servilletas y cortinas, alguna alhaja personal ${ }^{69}$, pero lo que más destaca es otra vez el ropero personal. Así, a lado de las prendas de carácter religioso, los balandranes y las sotanas, abundan las de influencia francesa: casacas - dos nuevas, chupas, calzones, algunos elaborados ya con algodón, pana, y otros descritos como nuevos ${ }^{70}$, un cabriolé y tres chalecos. En definitiva, haber dejado el convento de la ciudad de León, y residir en áreas rurales como párrocos o priores, no implicaba abandonar los gustos en la ropa y sobre todo en la vestimenta, con la adopción de las novedades. En este sentido podemos señalar que se siguen comportando más como canónigos que como curas rurales.

\section{CONCLUSIONES}

Frente a una imagen a priori homogénea, dada su condición de eclesiásticos regulares, de los canónigos de San Isidoro de León, en el estudio realizado observamos en primer lugar, contrastes en la los bienes globales y su valoración, situándose en una escala superior los canónigos que a su vez ejercen como párrocos o priores de alguna parroquia rural, fuera de la ciudad leonesa.

En segundo lugar, las diferencias se aprecian también en los objetos que conforman lo que hemos denominado como condiciones o estilo de vida, saliendo favorecidos a lo largo del periodo analizado los que solo eran canónigos de la Colegiata leonesa y no los que tenían un mayor nivel de bienes globales: los canónigos y párrocos o priores.

En tercer lugar, fijándonos en los textiles de sus espacios, cuartos, y en los de la ropa y alhajas del cuerpo, de nuevo vuelven a aparecer las diferencias entre los religiosos, incluso los que son de una misma categoría, y en todas las etapas estudiadas. Ahora bien, esta diversidad se refleja principalmente en el número de piezas o prendas, en la calidad de las mismas, y no tanto en la llegada de novedades. De este modo, al margen de la cuantía en reales conseguida por la venta en almoneda de este tipo de bienes, tanto los priores de la Colegiata, como los canónigos y los canónigos párrocos, se mostrarán partidarios de disponer, sobre todo en su roperos personales, de las nuevas prendas de influencia francesa: casaca, chupa y calzón, y de las más vanguardistas

\footnotetext{
${ }^{68}$ Ya aparecerán dos colchas de algodón vendida una en 29 reales y la otra en el Sr. Prior por 60 reales. Id., $49-8$.

${ }^{69}$ Se venden 14 botones de camisa de plata a un canónigo de la Colegiata en 13 reales. Ibidem.

${ }^{70}$ En el baúl de la antesala hay siete varas y media de cotonia. Ibidem.
} 
conectadas con los gustos burgueses.

En definitiva, consideramos que se abre un panorama mucho más complejo y estimulante, de cara a los estudios sobre las condiciones de vida y el consumo, que rompe con la idea tradicional de un clero regular masculino uniforme y con escasas posibilidades como agentes de demanda de productos conectados con estilos más burgueses. 


\title{
¿UN CONSUMO IMPRESCINDIBLE? EL TRAJE FEMENINO EN LAS CARTAS DE CAPITAL DEL VALLE DE LECRÍN (1730-1770) ${ }^{1}$
}

\section{AN INDISPENSABLE CONSUMPTION? WOMEN'S CLOTHING IN THE CHARTERS OF THE CAPITAL OF LECRÍN VALLEY (1730-1770)}

\author{
MARGARITA M. BIRRIEL SALCEDO \\ Universidad de Granada
}

Recibido: $12 / 09 / 2016$

Aceptado: 09/03/2017

RESUMEN: Este texto nace de las preguntas que se me plantearon al estudiar las cartas de capital del Valle de Lecrín en el siglo XVIII, documento otorgado siempre por un varón. A lo largo de esta investigación, además de fijar qué indumentaria es la que se escritura, se ha podido definir que estos trajes son galas y regalos con motivo de la boda. Práctica habitual en la España del Setecientos y que adquieren todo su sentido en el marco de una economía del don de la que el matrimonio es un ejemplo ideal.

PALABRAS CLAVES: capitales, traje femenino, regalos de boda, economía del don, siglo XVIII, reino de Granada, Valle de Lecrín

SUMMARY: This text is the result of the questions put to me after studying the charters of the capital of Lecrín Valley in the 18th century, a document that was always granted by a man. During the study, in addition to establishing the type of clothing recorded, it was determined that they were wedding regalia and gifts. This practice was common in the Spain of the 700s and fits perfectly into the framework of a gift economy in which marriage is the best example.

KEYWORDS: capitals, women's clothing, wedding gifts, gift economy, 18th century, Kingdom of Granada, Lecrín Valley.

Hace seis años la casualidad me llevó a iniciar una investigación sobre el Valle de Lecrín, comarca natural de la actual provincia de Granada, que en el siglo XVIII constituía un distrito bien definido en la organización territorial civil,

\footnotetext{
${ }^{1}$ Este trabajo se financió en el proyecto HAR 2013-48901-C6-6-R Familia, desigualdad social y cambio generacional en la España centro -meridional (1700-1900).
} 
militar y eclesiástica del reino de Granada: el Partido del Valle de Lecrín ${ }^{2}$. En esa tarea, la explotación de los archivos provinciales, en especial el notarial, ha hecho posible sacar a la luz una documentación poco conocida, las cartas de capital, pero que se han presentado de gran interés para comprender mejor el matrimonio en el reino de Granada en el siglo XVIII. Precisamente es un aspecto concreto de los flujos de bienes entre los contrayentes lo que va a centrar el estudio que aquí se presenta: la presencia habitual de ropas y joyas femeninas en las cartas de capital, a pesar de ser la escritura del patrimonio masculino. Ante ello, mis preguntas iniciales fueron: si había una obligación ineludible, una compulsión cultural; si los actores sociales aportaban una explicación significativa; y, por último, dado que la destinataria es la esposa por qué aparecía en las cartas de capital y, en consecuencia, cuál era su sentido en todo el entramado matrimonial.

\section{LA CARTA DE CAPITAL.}

La carta de capital es clasificada por Matilla Tascón como una escritura pública relacionada con transferencias o declaraciones de bienes ${ }^{3}$. En el caso que yo estudio, el Valle de Lecrín en el siglo XVIII, estas cartas, firmadas siempre por un varón, aparecen principal, pero no exclusivamente, asociadas al matrimonio y, más en concreto, al momento en que se otorga la carta de dote y arras. Lo habitual es el registro consecutivo de ambas escrituras. Así sucede con la carta de dote y arras y la de capital otorgadas por Matías López, próximo a casarse con doña Teresa Montosa (Saleres, 1730); o las otorgadas por Manuel Escribano quien el día de la boda hace constar los

\footnotetext{
${ }^{2}$ Es una comarca natural y distrito administrativo y eclesiástico del antiguo Reino de Granada, bajo la jurisdicción de la ciudad de Granada, salvo Villamena de Cozvíjar que es de señorío. La agricultura es la actividad que ocupa a un mayor número de personas aunque la arriería va a emplear, en algunos pueblos, hasta un tercio de los cabezas de casa varones. J.F. GARCÍA (2014). Paisajes históricos del área norte del Valle de Lecrín de la época nazarí a la conquista castellana. Granada: Universidad de Granada; y M.M. BIRRIEL SALCEDO (2015). "Género y espacio doméstico: la casa rural en el siglo XVIII”, en Díez Jorge, E. (Dir.). Arquitectura y mujeres en la Historia. Madrid, Síntesis, pp. 305-340.

3 A. MATILLA TASCÓN (1980). Inventario general de protocolos notariales. Madrid. Archivo Histórico de Protocolos, s.p. Las escrituras utilizadas en esta investigación son todas del Archivo Histórico de Protocolos de Granada [AHPR-Gr]. Distrito Órgiva[DO], de los escribanos ubicados en Pinos del Valle y Restábal entre 1730 y 1770, incluyen el registro de casi todos los pueblos del Valle de Lecrín, con excepción de Padul y Dúrcal que cuentan con sus propios escribanos.
} 
aportes patrimoniales suyo y de su esposa, María Cayetana Gutiérrez (Pinos del Valle, 1747); eigual sucede cuando se escrituran meses o años después de la boda, caso de Juan Lozano, marido de doña María Morales (Cónchar, 1770) .

Una de las cartas estudiadas, la de José Delgado, expresa de forma nítida los objetivos de esta escritura: " para venir al conocimiento de los bienes que el otorgante lleva al matrimonio quiere hacer escritura de capital de ellos que los recibe de mano de María Medina su madre [viuda]"'. Seguidamente, tras relacionar los bienes aportados, el otorgante reitera que son "por cuenta de la legítima paterna y materna". Y concluye declarando su recepción. Así pues, en el documento por una parte se da fe pública de la transferencia generacional de patrimonio porque va a casar, lo que nos recuerda la donación por razón de matrimonio, una dote masculina. Además, manifiesta una vez más el largo tempo de la transmisión patrimonial, son parte de la herencia habida o por haber y como dicen otras escrituras, tendrá que traerlo a colación en el momento de las particiones hereditarias. Y, por último, y de ahí su emparejamiento con la dote, un objetivo fundamental es justificar lo que el varón aporta al matrimonio a fin de no confundirlos con los bienes dotales; o que no puedan ser reputados como gananciales. A diferencia de otros territorios en el reino de Granada no suelen hacerse capitulaciones matrimoniales, sin embargo en el siglo XVIII este registro paralelo de dotes y capitales, de los aportes de una y otro para sostén de las cargas del matrimonio, permite comprender mejor lo que las familias

\footnotetext{
${ }^{4}$ Saleres, 10 de septiembre de 1730. Carta de dote y arras de doña Teresa Montosa contra Matías López. AHPRGr.DO.Restábal, 1730, s.f.; Saleres, 10 de septiembre de 1730. Carta de capital de Matías López. AHPRGr.DO.Restábal, 1730, s.f.- Pinos del Valle, 25 de diciembre de 1747. Carta de dote y arras de María Cayetana Gutiérrez contra Manuel Escribano. AHPRGr.DO. Restábal, 1742-1751, ff. 382r-383v; Pinos del Valle, 25 de diciembre de 1747. Carta de capital de Manuel Escribano. AHPRGr.DO. Restábal, 1742-1751, f. 384r-v.Cónchar, 24 de diciembre de 1770. Carta de dote y arras de doña María Morales contra Juan Lozano, su marido. AHPRGr.DO. Pinos del Rey, 1765-1770, ff. 1113r-1115r; Cónchar, 24 de diciembre de 1770, Carta de Capital de Juan Lozano. AHPRGr.DO. Pinos del rey, 1765-1770, ff.1116r-v.

${ }^{5}$ Pinos del Valle, 16 de mayo de 1736. Carta de capital de José Delgado. AHPRGr. DO. Pinos del Rey, 1730-41, f. 416r. Debo indicar que cuando el varón va a contraer segundas nupcias no suele hacer carta de capital sino que procede a inventariar su patrimonio -y el de sus hijos- para que no haya confusión.
}

${ }^{6}$ Ibidem, f. 416v. 
ponen en juego en el matrimonio de las hijas e hijos, y la capacidad económica de los hogares en el momento de su constitución?

Si bien este vínculo capital-matrimonio es lo usual, no es raro encontrar escrituras, que pese a estar relacionadas con la transmisión del patrimonio, responden a situaciones diferentes como son la emigración, la emancipación o la simple fe pública de que se tiene un determinado patrimonio. Un ejemplo de lo dicho es la carta de capital otorgada por José Martínez en $1753^{8}$. El otorgante explica en el texto que su madre quiere proceder a igualarlo con sus hermanos haciéndole entrega de la legítima paterna y un adelanto de la materna. Todo lo cual deberá llevar a colación cuando llegue su momento. Estos son bienes por valor de 2500 reales de vellón. Ahora bien, una vez establecido lo que recibe por este concepto, la madre declara que él, José Martínez, que aún no ha alcanzado los 25 años, es, sin embargo, hombre capaz por lo que ha constituido por sí mismo, gracias a su trabajo y sagacidad, un capital en tierras, alambique y ganado por 7400 reales. Patrimonio que solo a él pertenece y que al ser fruto de su esfuerzo no tiene que traer a colación cuando lleguen las particiones hereditarias. Este ejemplo es singular pero indicativo de los usos del documento para manifestar en escritura pública la propiedad de ciertos bienes.

Para esta investigación se han estudiado 123 cartas de capital otorgadas entre 1730 y 1770 . Comprenden desde 400 reales de vellón, la de menor cuantía, hasta los 37990 reales la de mayor. Dos cifras extremas que no son para nada representativas, la media es de 4049 reales, que es una cifra en la horquilla entre 1001 reales y 5000, que es dónde se sitúa el $65 \%$ de las otorgadas, aunque lo habitual es que las cartas oscilen entre 1500 y 3500 reales de vellón (47\%).

Tras la intitulación y la exposición de motivos, la relación de bienes incluye una somera descripción y su tasación. Como es lógico no hay una única fórmula pero en términos generales este capital comprende principalmente tres grupos de bienes: inmuebles, los gastos de la dispensa matrimonial e indumentaria. En menor medida se

${ }^{7}$ M.M. BIRRIEL SALCEDO (2016). "Riqueza y género en la España del Sur”, XI Congreso de la Asociación de demografía Histórica, Cádiz, 2016, Inédito. En este sentido lo recoge A. SANZ TRELLES (1998). Catálogo de Protocolos notariales de Gibraltar y su campo (15221713). Algeciras: Instituto de Estudios Campogibraltareños, p. 111; y M. GÓMEZ (1997). "Dote y herencia en la Vega de Granada. Alfacar en el siglo XVIII", en López-Cordón, M.V. y Carbonell i Esteller, M. (Dirs). Historia de la mujer e historia del matrimonio. Murcia: Universidad de Murcia, pp. 183-190.

${ }^{8}$ Pinos del Valle, 6 de mayo de 1753. Carta de capital de José Martínez. AHPRGr. DO. Pinos del Valle 1752-1761, s.f. 
documentan dinero, semovientes, aperos de labranza, materiales de construcción o productos en especie como semillas o aceite.

El capital de Francisco Bazán (Pinos del Valle, 1730) puede ser un ejemplo tan bueno como cualquier otro. Este aporta al matrimonio inmuebles: varias hazas de secano y olivares hasta 1950 reales de vellón; una casa en Barrio Bajo de Pinos del Valle, o mejor, un solar con la traza del edificio y materiales de construcción, 750 reales. En segundo lugar, un borrico, 150 reales. En tercer lugar, los gastos de la buladispensa para casar, 350 reales. A lo que hay que añadir, las joyas y ropas para la novia, 463; y finalmente, dinero contante y sonante por valor de 480 reales de vellón. Suma en total 4123 reales de vellón9. Aquí la ropa es, sin embargo, una parte relativamente pequeña del total.

Como se deduce de las cuantías (y la de las dotes correspondientes) estas escrituras tienen un sesgo que no se puede soslayar: Los otorgantes tienen algo que escriturar, son labradores y arrieros de medianos a ricos, junto a los escribanos y familiares de clérigos.

En fin, estas escrituras hasta ahora poco exploradas en las investigaciones del reino de Granada son de uso habitual en el siglo XVIII. En tanto que fuente, son extremadamente útiles para comprender cómo funciona la transmisión patrimonial de una a otra generación así como la capacidad económica inicial de los hogares en el momento de su constitución. Además, es muy interesante para vislumbrar cuál es la fuente del capital masculino tantas veces soslayada por la historiografía. Así pues son tan interesantes como las dotes para comprender las prácticas de la transmisión patrimonial y, al igual que ellas, también indicadoras del consumo al incluir la ropa que nos ocupa ${ }^{10}$. En efecto, sus características y continuidad a lo largo del siglo permiten establecer un perfil del consumo de la indumentaria relacionada con la boda, principalmente de la femenina, aunque también de la masculina. Sin duda era un gasto

\footnotetext{
${ }^{9}$ Pinos del Valle, 7 de octubre de 1730. Capital de Francisco Bazán. AHPRGr.DO. Pinos del rey, 1730-1741, ff. 10r-11r. La esposa, Juana Díaz Rodríguez, aporta de dote 2868 reales de vellón y recibe en arras. 1100.

${ }^{10}$ M. GARCÍA FERNÁNDEZ (1999). "Los bienes dotales en la ciudad de Valladolid, 17001850. El ajuar doméstico y la evolución del consumo y la demanda", en Torras, J. y Yun, B. (Dirs.). Consumo, condición de vida y comercialización: Cataluña y Castilla, ss. XVII-XIX. Valladolid: Junta de Castilla- León; pp. 134-157. Aprovecho para agradecer aquí todas los comentarios y sugerencias que se me hicieron en la presentación de una primera versión de este texto en el Congreso de Demografía Histórica, Cádiz, 2016. Y muy especialmente las del Dr. Máximo García Fernández y Dr. Juan Manuel Bartolomé Bartolomé.
} 
excepcional, pero habla de una demanda, de unos objetos que deben ser adquiridos cada vez más en el mercado y, esto es lo más interesante pone de manifiesto las pautas culturales que la sustentan.

\section{LA ROPA EN LAS CARTAS DE CAPITAL}

Señalábamos más arriba que la composición de estas cartas de capital hace referencia principalmente a tres grupos de bienes: propiedad inmueble(tierras y casas); los gastos de las dispensas matrimoniales; y ropa de vestir, que es de lo que aquí me voy a ocupar. Pero tal vez habría que hablar con más propiedad de indumentaria ya que puede incluir joyas, zapatos, o guantes.

Aunque el peso de la ropa en las escrituras va a depender mucho de las cuantías finales, lo habitual es que comprenda entre el 17 y el 33 por ciento de las mismas. Como cabe esperar hay singularidades, casos extremos, como el de Francisco Barranco (Saleres, 1731) cuyo capital, pequeño, 600 reales, comprende solo indumentaria ${ }^{11}$. En el extremo opuesto tendríamos las cifras de la escritura de Juan López (Ízbor, 1752) que solo dedica el $3.75 \%$ a trajes, en un capital de 8004 reales de vellón ${ }^{12}$.

En una primera lectura fue la presencia de ropa femenina lo que atrajo mi atención, no obstante, una lectura más completa ha mostrado que también incluyen ropa masculina aunque se relaciona con menos frecuencia y, en varias de las cartas, aparecen solo piezas sueltas que pueden generar confusión con la indumentaria femenina. No hay ropa blanca, solo ropa de vestir. Establecido esto, indicar que las piezas se repiten en una pauta que nos indicaría un modelo, o si se prefiere un estereotipo. Es mucho más claro en el caso de la ropa femenina pero también se percibe en aquellas otras que presentan un conjunto o traje completo de varón.

Estaríamos hablando para los varones de unos calzones, una casaca y una capa de paño; en ocasiones un capote o chupa; excepcional la chamarra. En el de las mujeres, una armilla, guardapiés, basquiña o pollera, todo de diversos materiales, y el manto, siempre de seda. A esto puede añadirse una mantilla, coletillos o dengue. Otras piezas o complementos son excepcionales como las medias de seda, los zapatos, guantes y abanicos. En cuanto a las joyas, casi siempre femeninas, solo están presentes en un

\footnotetext{
11 Saleres, 2 de enero de 1731. Carta de capital de Francisco Barranco. AHPRGr.DO. Restábal, 1731, s.f.

12 Ízbor, 18 de marzo de 1752. Capital de Juan López. AHPRGr.DO.Restábal 1752-53, f. 53r$\mathrm{v}$.
} 
$12 \%$ de las escrituras, siendo los chorros de oro y perlas junto a los zarcillos de oro lo más habitual.

Muy cerca de lo que parece ser el modelo ideal tendríamos los trajes incluidos en la de Francisco López (Tablate, 1731) ${ }^{13}$. Para ella: una basquiña de pelo de camello, un manto de seda, una casaca de nobleza negra, un guardapiés de calimaco, una mantilla de nobleza celeste, unos chorros de oro y perlas. Para él: una capa de paño fino, dos pares de calzones de paño, todo con sus forros y hechuras. En total 784 reales de vellón.

A la vez corriente y excepcional son los conjuntos que registra la carta de capital de Juan Recalde (Saleres, 1754) ${ }^{14}$. En primer lugar la indumentaria femenina: una cruz $\mathrm{y}$ unos pendientes de esmeraldas, una basquiña y casaca de damasco negro, un guardapiés y jubón de media tapicería, un dengue de grana con su galón de plata, un manto de seda con sus aforros, todo en 2000 reales de vellón. En cuanto al conjunto masculino: una chupa de nobleza negra, una chamarra de paño, unos calzones de terciopelo y otros de ante, todo en 430 reales de vellón.

Todos estos ejemplos hacen referencia a cartas de capital que incluían ropa para el novio y la novia. Pero dado que mi interés es la indumentaria femenina, añadiré otros ejemplos para que la panorámica de la indumentaria femenina sea aún más completa y precisa.

Una de las cartas más antiguas que se ha estudiado es la carta de capital de Miguel Ruiz (Restábal, 1730), que lo detalla así:

Un guardapiés de lamparilla en sesenta y seis [reales de vellón].

Una pollera de lo mismo en cincuenta y seis.

Una armilla de felpa en cincuenta.

Una mantilla de bayeta blanca, unos zapatos y unas medias, todo en treinta y siete reales y medio ${ }^{15}$.

\footnotetext{
13 Tablate, 28 de noviembre de 1731. Carta de capital de Francisco López. AHPRGr.DO. Restábal 1731, s.f. Este capital asciende a 2471; la dote de la esposa, Francisca González es de 2444, recibió en arras 1100 más.

${ }^{14}$ Esta es una de las cartas de capital más cuantiosas, 7474 reales (Saleres, 23 de febrero de 1754. Carta de capital de Juan Recalde. AHPRGr. DO. Restábal, 1753-1759, f. 530r-531). La esposa había aportado al matrimonio una dote de 10163 reales de vellón, recibió en arras 1100 más. 
En 1734, Antonio Escudero, vecino de Pinos del Valle, incluyó en su carta de capital las siguientes piezas de indumentaria femenina:

Primeramente una basquiña de tafetán doble, nueva, en ciento treinta reales de vellón.

Iten, un manto de seda, en cincuenta reales de vellón.

Iten más unos zarcillos de oro en cientocincuenta reales de vellón ${ }^{16}$

Por su parte Juan López Esteban, también de Pinos del Valle, otorgó carta de capital en 1754, en la que incluía: "Primeramente una basquiña de pelo de camello, una armilla de lustrina, un manto de seda, un pañuelo de borselina, todo en trescientos reales de vellón"17.

Más rico es el conjunto de prendas de mujer que Manuel Pinto incluyó en su carta de capital de 1761:

Iten una basquiña de pelo de camello en ciento y ochenta y siete reales de vellón.

Iten más un guardapiés de calimaco en ciento y treinta y siete.

Iten un jugón de mujeres de tapicería en ochenta y ocho reales de vellón.

Iten otro jugon de mujer de terciopelo, en cien reales de vellón.

Iten unos chorros de oro y otras alhajas de plata en trescientos veinte reales de vellón.

Iten un manto de seda, en cincuenta reales ${ }^{18}$.

La última en orden cronológico, de 1770, corresponde al vecino de Cónchar, Juan Lozano, quien añade a ganado, tierras y pertrechos de labrar ropa femenina: un guardapiés de calimaco nuevo, en ciento sesenta reales; una armilla de felpa negra en ochocientos; un manto de seda, cincuenta y cinco; una basquiña de camellón, ciento veinticinco ${ }^{19}$.

No es mi objetivo aquí estudiar el traje en sí mismo, lo que espero poder presentar

16 Pinos del Valle, 9 de septiembre de 1734. Carta de capital de Antonio Escudero. AHPRGr.DO.Pinos del Valle, 1730-1741, s.f.

${ }^{17}$ Pinos del Valle, 8 de marzo de 1752, Carta de Capital de Juan López Esteban. AHPRGr, DO, Pinos del Valle, f. 53r-v.

${ }^{18}$ Pinos del Valle, 25 de enero de 1761. Carta de capital de Manuel Pinto. AHPRGr. DO.Pinos del Valle, 1752-1761, ff. 555r-v

${ }^{19}$ Pinos del Valle, 24 de enero de 1770. Carta de capital de Juan Lozano. AHP-Gr, DO, Pinos del Rey, 1765-1770., ff. 116r-v. (Pinos del Valle fue nombrada unos años Pinos del Rey, por eso el protocolo dice Pinos del Rey) 
en un trabajo futuro incluyendo los datos que cartas de dote e inventarios nos ofrecen, que son muchos. Solo hacer un par de consideraciones al hilo de lo que descubren las piezas, las texturas y los colores que he descrito. Lo primero de todo es lo más evidente, aquí solo se hace referencia, tanto si es de varón como de mujer, a las prendas más externas del traje, quizás con la excepción del guardapiés aunque esta podemos considerarla seminterior como señala Herrero García ${ }^{20}$. En el mismo orden de cosas, la documentación manejada hace referencia en su mayor parte a basquiña, que es la falda más externa, no obstante, en unas pocas cartas, casi todas de los años 30 del siglo y de los protocolos de Restábal, registran la pollera. Ésta, como consagra la literatura sobre el traje en la España del periodo y el mismo Diccionario de Autoridades, es una falda interior, sobre la que se colocaría la basquiña. Sin discutir en absoluto esto, el hecho de que en la documentación que he manejado, si hay pollera no hay basquiña, $\mathrm{y}$ viceversa, me hace preguntarme sobre si ambas hacen referencia a una falda exterior, sin más. En fin, indicar esto para subrayar que, dada la calidad de los tejidos y las piezas referidas, la ropa incluida en las cartas de capital es ropa de vestir. Ciertamente hay diferencias entre ellas, pero incluso las de menor calidad y cuantía muestran esta aspiración de atavío para engalanarse y lucirse.

En segundo lugar, las piezas y los tejidos se repiten continuamente, lo que nos indica que es una indumentaria estereotipada, fijada por la costumbre, lo que en el caso de la indumentaria femenina estaría forzado por su carácter de regalo-gala. El cambio sería muy lento como demostró Máximo García para Valladolid ${ }^{21}$. Ahora bien, cambios hubo, y este es el tercer aspecto a considerar. La historiografía ha establecido como uno de los indicadores más importante el afrancesamiento de los atavíos. En el caso que se está estudiando, el Valle de Lecrín, los trajes masculinos, trajes de ostentación, sí se han visto afectados por la moda francesa, precisamente la universalización de casaca así lo indica ${ }^{22}$. Pero si lo que miramos es el traje femenino nada es tan evidente ni simple. La persistencia de la basquiña, armilla o manto nos remitiría más a una indumentaria que los viajeros extranjeros vieron como propia del

20 M. HERRERO GARCÍA (2014). Estudios sobre indumentaria española en época de los Austrias, Madrid, CEEH, p. 6.

${ }^{21}$ M. GARCÍA FERNÁNDEZ (2009). "Entre cotidianidades: vestidas para trabajar, de visita, para rezar o de paseo festivo", Cuadernos de Historia Moderna Anejos, VIII, pp. 119-150.

${ }^{22}$ A. GIORGI (2016). España viste a la francesa. La historia de un traje de moda en la segunda mitad del siglo XVIII. Murcia, Editum. 
país ${ }^{23}$. Esta especificidad, no obstante, no impidió la influencia francesa y cambios de tendencia tanto en la introducción de piezas de vestir como de materiales o colores a lo largo de la centuria. Esta tensión entre continuidad y cambio es lo que tendríamos que indagar en el futuro en el sentido no solo de qué indicadores de uno y otro hay, sino sobre todo en cómo las mujeres y los varones del Valle de Lecrín se apropian y resignifican piezas, tejidos y colores en su propio medio. De hecho cuando se definan algunos de los llamados trajes típicos en el siglo XIX, la fusión de elementos dispares es lo que los caracterice ${ }^{24}$.

Por último, es obligado preguntarse sobre si estas ropas eran nuevas o heredadas. En ningún caso hay indicación en la documentación de que fueran usadas y sí las hay de que son nuevas, como recoge la carta de capital de Juan Garbín (Béznar, 1731)²5:

* Primeramente un vestido de paño fino que se compone de una capa, capote, chupa y calzones, todo nuevo en doscientos reales.

*Un manto de seda nuevo en sesenta y siete reales

*Iten una mantellina de nobleza azul forrada de tafetán dorado nueva en ciento $y$ treinta $y$ dos reales [...]

O, en ese mismo año, la escritura de Cristóbal de Torres (Albuñuelas, 1731) donde también se especifica que la ropa es nueva: "Iten un manto de seda, una casaca de nobleza negra, una pollera de pelo de camello, un guardapiés de calimaco, todo ello nuevo..." ${ }^{26}$. Pero esta calidad de nueva no siempre es explícita, aunque numerosas

23 A. LEIRA SÁNCHEZ (2003). "El vestido y la moda en tiempos de Goya", en Textil e indumentaria: materias, técnicas y evolución. Madrid: Fac. Gegografía e Historia UCM, pp. 205-219; A. LEIRA SÁNCHEZ (2007). "La moda en España durante el siglo XVIII", Indumenta, $\mathrm{n}^{\circ}$ 0, pp. 87-94; E. MARTÍNEZ ALCÁZAR (2007-2008). "Características del atuendo español del setecientos a través de la documentación notarial de Murcia", IMAFRONTE, n 19-20, pp. 177-193; M. GARCÍA FERNÁNDEZ (2011). "La cuestión del traje nacional a finales del siglo XVIII. Demanda, consumo y gestión de la economía familiar", Norba. Revista de Historia, 24, pp. 151-165.

${ }^{24}$ R. DE LA PUERTA ESCRIBANO (2002). "Indumentaria popular del labrador de la Huerta valenciana (siglos XVIII-XIX)", Anales del Museo Nacional de Antropología, 10, pp.171-207. Véase también: J.M. BARTOLOMÉ BARTOLOMÉ (2015). "Consumos y apariencias externas de las familias de la burguesía leonesa”, Studia Historica, Historia Moderna, 37, pp. 269-290.

${ }^{25}$ Béznar, 8 de abril de 1731. Carta de capital de Juan Garbín. AHPRGr.DO. Restábal, 1731, s.f.

26 Albuñuelas, 13 de noviembre de 1731. Carta de capital de Cristóbal de Torres. AHPRGr.DO. Restábal, 1731, s.f 
noticias nos confirman que se adquieren para la boda. Así lo expresa Francisco de Olea (Pinos del Valle, 1749) 27: "Primeramente novecientos reales de vellón que el dicho mi padre tiene gastado en diferentes alhajas de vestir para la dicha mi esposa y mía; y en los gastos de diligencias de justicia [...]". También nos indica ese gasto el testamento de Francisco Delgado, vecino de Pinos del Valle quien explica que había adelantado a su hijo Andrés Delgado dinero para el breve del casamiento y, además, "pagué la ropa de vestir que Andrés regaló a su novia"28.

Quiero destacar estos últimos testimonios porque inciden directamente en mis preguntas iniciales. Ante todo, se infiere de la manera en que se testimonia la presencia de esta ropa de vestir, la importancia de los trajes, masculinos y femeninos, en la inversión que las familias hacen para la boda, momento crucial de la vida de las gentes de la Edad Moderna. Además, centrándonos en la indumentaria femenina que generó las preguntas iniciales, parece deducirse de lo documentado que estos trajes que se consignan en las cartas de capital del Valle de Lecrín, trajes de gala y lucimiento, son regalos para la novia.

Esta práctica no es exclusiva de nuestra comarca. La adquisición de prendas lujosas -para el novio y la novia- en el momento de la boda es práctica habitual de las familias. Galas y regalos, como las designa la historiografía, consumía una parte importante de los gastos del matrimonio precisamente porque en Europa, la celebración del matrimonio está rodeada de ritos marcados por el intercambio de dones. La historiografía ha prestado siempre atención a los regalos de las bodas entre miembros de las dinastías reinantes, por bien documentados, sin duda; también de la nobleza ${ }^{29}$. Menos referencias tenemos de los intercambios con ocasión de las bodas de las clases populares, aunque en los últimos años se empieza a documentar sobradamente esta

${ }^{27}$ Pinos del Valle, 26 de julio de 1749. Carta de capital de Francisco de Olea. AHPRGr.DO. Restábal, f.487r.

${ }^{28}$ Pinos del Valle, 26 de agosto de 1735. Testamento de Francisco Delgado.AHPRGr. DO. Pinos del Rey 1730-1741, f.320r.

${ }^{29}$ R. DE LA PUERTA ESCRIBANO (2000). "Reyes, moda y legislación jurídica en la España moderna”, Ars Longa, 9-10, pp.65-72; Ma DEL M. NICOLÁS MARTÍNEZ (2008). “Galas y regalos para una novia: a propósito de la boda de María del Pilar Teresa Cayetana de Silva, duquesa de Alba", Congreso Internacional Imagen Apariencia. [ en linea: Congreso Internacional Imagen Apariencia. Noviembre 19, 2008 - noviembre 21, 2008, consultado el 8 de mayo de 2016]. F. CHECA (2010). "Fiestas, bodas y regalos", en Zalama Rodríguez, F. (Dir.). Juana I en Trodesillas: su mundo, su entorno, Valladolid, Ayuntamiento de Tordesillas, pp. 135-162. 
práctica en el medio rural castellano con el estudio sobre todo de capitulaciones matrimoniales y la relectura de las fuentes literarias ${ }^{30}$.

Y si el intercambio de regalos es práctica habitual, también lo es que, en la España del siglo XVIII, el novio mande a la novia unos regalos donde se incluye un traje completo. Lamentablemente, para el reino de Granada, no se cuenta hasta el presente, información detallada sobre esta costumbre. Pero pienso que es ilustrativo el estudio hecho por Rosario Die y Armando Alberola sobre la compra de trajes para la novia con motivo a propósito de la boda de una joven pareja de la pequeña nobleza alicantina, los Cornella y Juan ${ }^{31}$. Este trabajo, basado en la correspondencia entre diversos miembros de las familias, no solo detalla la compra del traje sino, sobre todo, la compulsión cultural del regalo, expresada a través de emociones, de la ansiedad nacida del retraso en la tarea y en la necesidad de satisfacer con el regalo adecuado las expectativas de la alianza entre ambas familias.

Así pues, al igual que el ejemplo mencionado, se puede caracterizar a la ropa femenina que aparece en las cartas de capital del Valle de Lecrín en el siglo XVIII como regalos, es decir, como parte de un sistema intercambios que no se explican solo por su conmodificación. Aunque la materialidad del don esté siempre en la balanza hay más cosas en juego: estatus, prestigio, poder, reconocimiento, etc.

\section{DAR Y RECIBIR}

Dar y recibir regalos (dones, legados...) constituye uno de las fórmulas más habituales de intercambio en las sociedades humanas y todavía hoy forma parte de

\footnotetext{
${ }^{30} \mathrm{M}^{\mathrm{a}}$ A. SOBALER SECO (2013). "Un consumo festivo. Galas y gastos de boda en las capitulaciones matrimoniales de una zona rural castellana en el siglo XVIII", en García Fernández, M. (Dir.). Cultura material y vida cotidiana moderna: Escenarios. Madrid: Sílex, pp. 39-52; A. RISCO (2004). "El obispo y el príncipe”, en Fernández, R. y Soubeyreaux, J. (eds.). Historia social y literatura: Familia y clero en España (ss. XVI-XVII). Lleida, Editorial Milenio, pp. 163-189.

${ }^{31}$ R. DIE MACULET y A. ALBEROLA ROMÁ (1996). "Una boda de la pequeña nobleza alicantina del Setecientos: Los Soler de Cornellá y los Juan a través de su correspondencia”, Revista de Historia Moderna, $\mathrm{n}^{\circ}$ 13/14, pp. 253-311. Véase también M.M. NICOLÁS MARTÍNEZ (2009). "Galas y regalos para una novia. A propósito de la boda de María del Pilar Teresa Cayetana de Silva, duquesa de Alba", en Congreso internacional Imagen y Apariencia (2008). Murcia: Universidad de Murcia, sin paginar [consultado 1 de septiembre de 2016, en línea. https://dialnet.unirioja.es/congreso/3813].
} 
nuestro universo relacional ${ }^{32}$. Una primera clasificación del don se refiere a si este se corresponde con una ocasión ritualizada o no. Entre las primeras se encuentran aquellos ligados a los ritos de paso de una sociedad, muy especialmente el matrimonio, intercambio que parece se produce en todas las culturas y donde mejor se puede apreciar uno de los rasgos fundamentales del regalo: su carácter relacional. El don es entonces signo de un vínculo, el del matrimonio que es la alianza entre familias o grupos más extensos de parientes. A diferencia de la antropología que ha visto dotes, precio de la novia y otras prestaciones matrimoniales como parte de una economía del don, en general, muy institucionalizada y equilibrada entre los intervinientes, la historia ha priorizado el papel que estos capitales cumplen en la transmisión patrimonial y en las estrategias reproductivas de las partes, enfatizando su utilitarismo. Esto ocurre porque se tiende a considerar que hay solo dos sistemas de interacción social, el mercado y el estado. Sin embargo, en los últimos años, quizás por el giro cultural, se va haciendo más evidente que los seres humanos no viven solo para el mercado y el estado, ni solo en el mercado y el estado. Lo que lleva a Godbout-CailléWinckler a recordarnos que:

The trasnformation of individuals into social persons does not occur first in the relatively abstract sphere of the market and the state, even if they make a certain contribution, but in the world of primarily sociality, here, within the family, in relations with neighbors in comradeship and friendship, person-to-person are forge ${ }^{33}$.

Ellos hablan de economías complementarias, mercado, estado y don. Y lo entienden en el sentido del sistema social concernido por las relaciones personales (no solo individuos, sino parientes, vecinos, etc.).

Estos autores nos proponen una metodología que permita comprender un fenómeno social como es el regalo en muy diversas sociedades Tal vez, no sea, a la larga, la única ni la mejor vía para indagar sobre ciertas prácticas sociales que no se pueden explicar solo en términos económicos o institucionales, pero me sirve, aunque solo sea como punto de partida, para leer la persistente permanencia de los regalos en el momento de

\footnotetext{
${ }^{32}$ N.Z. DAVIES (2000). The Gift in Sixteenth Century France. Madison: The University of Wisconsin Press; Y. YAN (2005). "The gift and Gift Economy", en Carrier, J.G (ed.). A Handbook of Economic Anthropology. Chetelham: Edward Elgar.

${ }_{33}$ J.T. GODBOUT, A.C. CAILLÉ y D. WINKLER (1998). The World of Gift. Quebec: MQUP, p. 15.
} 
las bodas. Y las obligaciones no solo económicas que llevan a repetir de continúo la donación de ciertos bienes.

Al hacerme la pregunta inicial sobre los trajes femeninos registrados en las cartas de capital, y dado lo que sabemos de ellos, parece evidente que es preciso revisar el conjunto de las prestaciones matrimoniales, dotes, arras o regalos, en el marco del sentido que tienen en la economía del don, la que principalmente teje y refuerza vínculos y relaciones. Ya hace unos años proponía en otra publicación sobre el matrimonio, la necesidad de incluir la economía, o si se prefiere, la lógica del don, del regalo, en el estudio de las prestaciones matrimoniales en Castilla para comprender por qué las arras no desaparecen. En aquella ocasión consideré a las arras como un contradón vinculado al acceso carnal al cuerpo femenino y que permanece no tanto por su valor crematístico cuanto por lo que tiene de signo del vínculo que se forja con la consumación del matrimonio ${ }^{34}$. Al enfrentar el papel de los regalos y más específicamente lo que se ha expuesto del traje y las joyas femeninas en las cartas de capital, pienso que solo en el contexto de la economía del don es comprensible. Veámoslo.

Como ya se ha dicho, en toda Europa la celebración del matrimonio está rodeada de ritos marcados por el intercambio de dones. Donaciones que recibirán diversas denominaciones: vestidos, paños, donas, galas, y que se reconocen como el conjunto de liberalidades que los esposos pueden hacerse como regalos nupciales. Desde la Baja Edad Media se intensifica su regulación en el marco de las transformaciones jurídicas del matrimonio y la herencia, aunque, sobre todo en la Edad Moderna, se explicita como el fin principal de estas regulaciones limitar los fraudes e incrementos desaforados de capital que envolvían estas donaciones. En la Corona de Castilla, es bastante bien conocida la legislación medieval a la que se suman, en la Edad Moderna, las Leyes de Toro (1505) y diferentes Pragmáticas, recogidas en la Nueva y Novísima Recopilación, de $1534^{35}, 1623^{36}$ y $1723^{37}$. Estas últimas, intentaron regular y limitar el flujo de bienes a la hora de casar. Es decir, cómo se hacen las donaciones y cuanto puede invertirse en dichos regalos. Las razones aducidas para esta regulación se

\footnotetext{
${ }^{34}$ M.M. BIRRIEL SALCEDO (2007). "Mujeres y matrimonio: sentido y significación de las arras en la Corona de Castilla”, en López Beltrán, M.T. (ed.). Historia y género. Imágenes y vivencias de mujeres en España y América (ss. XV-XVIII). Málaga: Universidad de Málaga, pp. 69-100.

${ }^{35}$ Nueva Recopilación ,5,2,1

${ }^{36}$ Nueva Recopilación, 5,2,5

${ }^{37}$ Novisima Recopilación 10,3,8.
} 
centran en garantizar el dominio de los bienes del donatario y su transmisión patrimonial. También es bien conocido que estos intentos no frenaron ni los regalos ni el endeudamiento, o simplemente la superación sin más de los límites legales de las cuantías. Sin ir más lejos, al relacionar los capitales de nuestros vecinos del Valle de Lecrín con las arras comprometidas, aunque estas estén estereotipadas, superan en más casos que en menos la décima parte del capital del esposo ${ }^{38}$. En cuanto a la legislación de Toro tuvo por objeto precisar más finamente la naturaleza jurídica del regalo y cuando era ganado por la esposa en el marco de todas las prestaciones matrimoniales ${ }^{39}$. Más en concreto, la ley 52 de Toro hace referencia a la sponsalicia larguitas, es decir, dona, galas y regalos, y en ella se establece que habiendo arras, la esposa o sus herederos deben escoger entre las arras o los regalos, volviendo al tronco del que salió, los parientes del marido, lo que no pasa a ella, pero también estableció una cuantía máxima para estas liberalidades.

El carácter de las donas, galas y regalos que son la sponsalicia larguitas, estuvieron sometidas a las largas controversias y pleitos tanto en la Baja Edad Media como en la Edad Moderna. Además de si se aplicaba la Ley del Ósculo y la detallada casuística de cuando es válido el regalo, algunos comentaristas, como Gregorio López, distinguieron unos regalos de otros, insistiendo en una concepción medieval de que los dones como joyas y atuendos lujosos (los escusados de las Partidas), debían siempre retornar a los herederos del marido, porque no eran "como un regalo del novio a la desposada, sino dados a la mujer para que usase de ellos" ${ }^{\prime 4}$. Esta línea interpretativa es vista por la historia del derecho como un subterfugio para no colisionar frontalmente con la norma legal, ya que, como he indicado, estos regalos, donas, ropas, galas se prestaban a traspasar los límites legales y a generar pleitos entre parientes.

Ahora bien, cuando enfrentamos esta legislación y líneas interpretativas con el caso que nos ocupa, y a diferencia de lo que yo estudie para el siglo $\mathrm{XVI}^{41}$ en el reino de

${ }^{38}$ M.M. BIRRIEL SALCEDO (2016). "Riqueza y género en...”. También sucede así en la vecina Alpujarras estudiada por J. CASEY (1988). "Matrimonio y patrimonio en un pueblo Alpujarreño: Órgiva, 1600-1800", en Sierra Nevada y su entorno. Granada: Universidad de Granada, pp. 183-200.

${ }^{39}$ M. BERMEJO CASTRILLO (2006). "Las Leyes de Toro y la regulación de las relaciones familiares", en González Alonso, B. (coord.). Las Cortes y las Leyes de Toro de 1505. Salamanca, Cortes de Castilla y León-Ayuntamiento de Toro, pp. 383-548.

${ }^{40}$ BERMEJO CASTRILLO (2006), “Las leyes de Toro...”, op. cit. pp. 436.

41 M.M. BIRRIEL SALCEDO (1998). "Más allá del Repartimiento: Género, familia y patrimonio", Chronica Nova, 25, pp.77-91; M.M. BIRRIEL SALCEDO (2002). "Entre una 
Granada, aquí no hay una atribución formal de los vestidos femeninos como donación esponsalicia. Aunque parezca haberla de facto. Formalmente la ropa femenina de la que hablamos (y también las joyas) aunque se nos presentan como regalos son parte del capital masculino, capital cuyo registro, tal y como señalé al principio, tiene por objeto no confundir los bienes propios del varón ni con dotales ni con gananciales ${ }^{42}$.

Esto se presentaba como un desafío, ¿un regalo cuya propiedad no se transfiere? Pues sí. Es preciso comprender como dijimos más arriba que la regulación de las donaciones por razón de matrimonio tiene por objetivo hacer posible la constitución del nuevo hogar y la transmisión patrimonial, sin dejar exangüe a las familias intervinientes. Eso incluye la vuelta al tronco del que salió de aquel patrimonio que o bien no cumple los objetivos por los que fue donado, o bien contribuye a comprometer excesivamente los patrimonios de las familias que las regalaron ${ }^{43}$. Además, conectando con las interpretaciones indicadas de reservar las joyas o atuendos lujosos, es decir, no transferir la propiedad plena sino su uso, no se nos presenta como imposible.

En este sentido y dado el tipo de bienes de los que estábamos hablando no parecía descartado introducir, en el marco de una economía del don, la sugerente idea de Annette Weiner ${ }^{44}$ de riqueza inalienable, quien formula la paradoja de keeping while giving (retener al dar) en relación al conjunto de dones que circulan en un sistema de regalos pero que siempre vuelven al primer donante. Si bien Weiner hace referencia a bienes que tienen un fuerte valor místico en la comunidad, lo cierto es que ella, en su propia argumentación que incluye ejemplos de la Francia de Luis XIV, nos remite a objetos que operan como repositorios simbólicos de genealogías y acontecimientos familiares identificados con una serie sucesiva de dueños pertenecientes a un grupo de parentesco. Esta lectura parece muy adecuada para una parte de los objetos que se incluyen en estos regalos, las joyas, que con frecuencia han pasado de generación en

ley y otra: la transmisión del patrimonio entre los moriscos granadinos", en Barbazza, M-C. y Heusch, C. (eds.). Famille, Pouvoirs, Solidarités. Domaine méditerranéen et hispanoamericaine (Xve-Xxe siècles). Montpellier: Université Montpellier III, pp. 227-236.

${ }^{42}$ Para esta publicación no he podido hacer una comprobación exhaustiva del destino de los trajes una vez desaparecido el vínculo a través de los inventarios postmortem, lo visto hasta ahora parece confirmar que vuelven al esposo, pero como indico son pocos los documentos cotejados.

${ }^{43}$ M.M. BIRRIEL SALCEDO (2007). "Mujeres y matrimonio...".

${ }^{44}$ A. WEINER (1992). Inalienable Possessions: The Paradox of Keeping while Giving. Los Angeles: University of California Press. 
generación, como nos mostró Adela Fargas ${ }^{45}$, o que incluso siendo nuevas su perdurabilidad las termina trenzado en las genealogías e historias de familia. Sin embargo, no parece tan evidente con los trajes registrados en la documentación aquí manejada que, si como he afirmado son nuevos, y, en apariencia, carecerían de todo vínculo simbólico o emocional con aquellos que lo entregan. Pero, si así lo entendiéramos, se nos olvidaría entonces que lo que interesa en el intercambio es el acto mismo de dar y recibir; de expresar en el proceso la estima y reconocimiento de la donataria y su familia, de satisfacer las demandas que el estatus propio del novio y su familia exigen de liberalidad y de su ostentación. Y, por tanto, del hecho de que los regalos no son simplemente objetos que pasan de una a otra mano aunque sea vicariamente, sino el signo del acto que forja el vínculo, proyecta a la comunidad la estimación entre los cónyuges, y expresa el rango del donante. Ese dar reteniendo no es extraño en el universo del regalo, lo que lleva a Natalie Z. Davis a subrayar que los regalos añaden alegría y gentileza a las formalidades matrimoniales y, quizás, si la alianza prospera en un buen matrimonio, podría ser el legado del esposo a su "querida y amada esposa" ${ }^{46}$.

Esta afirmación me hizo preguntarme sobre cómo finalmente circulan estos regalos, si se devuelven y cómo. En estos momentos no me ha sido posible hacer un seguimiento de una misma familia. No obstante, sí que puedo afirmar que en los inventarios post mortem de los varones aparecen estas piezas de indumentaria femenina como parte de su patrimonio. Así el inventario de bienes de Manuel Muñoz (Pinos del Valle, 1751), que incluye dos guardapiés de calimaco, una basquiña de pelo de camello, una armilla de nobleza, unos chorros de oro, etc. ${ }^{47} \mathrm{O}$ el otorgado unos años después por Agustín de Salaberri (Pinos del Valle, 1759), que consigna una basquiña, un guardapiés, una mantilla, etc. ${ }^{48}$. Todo parece indicar que propiedad y uso están claramente delimitados y que lo que opera es un dar reteniendo.

\footnotetext{
${ }^{45}$ M. FARGAS PEÑARROCHA (2015). "Topografías de lo privado y de lo público. Joyas, familia y género en la época moderna", en Arias de Saavedra Alías, I. y López-Guadalupe Muñoz, M.L. (eds.). Vida cotidiana en la Monarquía Hispánica. Tiempos y espacios. Granada: Eug, pp. 216-229.

${ }^{46}$ N.Z. DAVIES (2000). The Gift..., p. 29.

${ }^{47}$ Pinos del Valle, 16 de mayo de 1751. Inventario de bienes de Manuel Muñoz. AHPR-Gr, Restábal, 1742-1751, ff. 672r-673v.

${ }^{48}$ Pinos del Valle, 17 de agosto de 1759. Inventario bienes de Agustín de Salaberri, AHPR-Gr, DO, Pinos del Valle, 1752-1761, f. 421r-424r.
} 


\section{CONCLUSIONES}

Una primera conclusión a las preguntas iniciales ha sido establecer que la ropa femenina incluida en las cartas de capital son trajes de vestir cuya composición está bastante formalizada -o estereotipada-, lo que se explicaría por ser regalos ritualizados. Lo que enlaza con la siguiente conclusión: La ropa femenina forman parte de los regalos del novio a la novia por razón de matrimonio. Regalos que, no obstante, nunca dejan de ser de él aunque el disfrute, mientras dure el matrimonio, sea de ella. Y la ropa aquí estudiada es solo una fracción del conjunto de intercambios que tiene lugar con ocasión del matrimonio. Regalos e intercambios que tienen todo el sentido en una economía del don aunque no se olvide el mercado y el estado.

En fin, estas páginas vuelven a llevarme a lo que ya escribí con ocasión de las arras y la que fue mi principal conclusión entonces, no se tendrá una comprensión completa de los flujos de personas y bienes que se producen en el matrimonio, si no incluimos en su investigación la economía del don. Y en la estela, una vez más, de Natalie Z. Davies, en la Europa Moderna dones y contradones (dotes, arras, donas, galas, etc.) proveen sostén a la vez concreto y simbólico a la donación mutua del esposo y la esposa en el matrimonio.

Entonces ¿un consumo imprescindible? Sin duda. 
Piezas de traje femenino y sus características

\begin{tabular}{|c|c|c|c|c|}
\hline Pieza & Tejido & Color(es)es & Adorno(s) & Otros \\
\hline Armilla & $\begin{array}{l}\text { Felpa } \\
\text { Lila } \\
\text { Lustrina } \\
\text { Nobleza } \\
\text { Tapiz }\end{array}$ & $\begin{array}{l}\text { Azul } \\
\text { Clavo } \\
\text { Negro }\end{array}$ & Punta de plata & \\
\hline Basquiña & $\begin{array}{l}\text { Camellón } \\
\text { Damasco } \\
\text { Doble } \\
\text { Pelo de camello } \\
\text { Tafetán } \\
\text { Tafetán doble }\end{array}$ & Negro & & \\
\hline Casaca & $\begin{array}{l}\text { Damasco } \\
\text { Nobleza } \\
\text { Seda } \\
\text { Terciopelo }\end{array}$ & Negro & & \\
\hline Coletillos & $\begin{array}{l}\text { Nobleza } \\
\text { Floripón [sic] }\end{array}$ & $\begin{array}{c}\text { Encarnado } \\
\text { Coral }\end{array}$ & & \\
\hline Dengue & Grana & & Galón de plata & Guarnecido de cartulina \\
\hline Guardapié & $\begin{array}{l}\text { Calimaco } \\
\text { Lamparilla } \\
\text { Lila } \\
\text { Nobleza } \\
\text { Media tapicería }\end{array}$ & $\begin{array}{c}\text { Azul } \\
\text { Encarnado }\end{array}$ & & $\begin{array}{l}\text { Forrado de holandilla } \\
\text { dorada }\end{array}$ \\
\hline Jubón & $\begin{array}{l}\text { Media tapicería } \\
\text { sempiterna }\end{array}$ & & & \\
\hline Manguito & & & & De persiana \\
\hline Mantilla & $\begin{array}{l}\text { Bayeta } \\
\text { Nobleza }\end{array}$ & $\begin{array}{c}\text { Azul } \\
\text { Blanco } \\
\text { Celeste } \\
\text { Verde } \\
\end{array}$ & & $\begin{array}{l}\text { Forrada de tafetán } \\
\text { dorado }\end{array}$ \\
\hline Manto & $\begin{array}{l}\text { Seda } \\
\text { Seda malagueña } \\
\text { Tafetán, } \\
\text { atafenado }\end{array}$ & & $\begin{array}{l}\text { Punta de } \\
\text { encaje }\end{array}$ & Con todos sus aforros \\
\hline Medias & Seda & & & \\
\hline Pañuelo & Borsalina & & & \\
\hline Pollera & $\begin{array}{l}\text { Calimaco } \\
\text { Lamparilla } \\
\text { Pelo de camello }\end{array}$ & & & \\
\hline
\end{tabular}

Fuente. Elaboración propia a partir de datos cartas de capital del Valle de Lecrín. 



\title{
VESTIDOS Y ADORNOS: LA CRÍTICA A LAS APARIENCIAS EXTERNAS A TRAVÉS DE LA PRENSA ESPAÑOLA (FINALES DEL SIGLO XVIII- SIGLO XIX)*
}

\begin{abstract}
DRESSES AND ORNAMENTS: CRITICISM OF OUTWARD APPEARANCES THROUGH THE SPANISH PRESS (LATE EIGHTEENTH CENTURY - NINETEENTH CENTURY)
\end{abstract}

\author{
FRANCISCO JAVIER CRESPO SÁNCHEZ \\ Universidad de Murcia \\ fcs42726@um.es
}

Recibido: $12 / 09 / 2016$

Aceptado: 22/11/2016

RESUMEN: Este trabajo estudia los discursos que sobre la moda y el lujo recogió la prensa española (especialmente la cercana al pensamiento religioso) entre finales del siglo XVIII y el siglo XIX con el objetivo de entender qué motivos se indicaban para querer controlar la apariencia externa. Así, elementos como la moralidad, la economía o los resultados negativos que provocaba en la mujer y en la familia, han sido los principales temas analizados a través de los artículos periodísticos.

PALABRAS CLAVE: prensa, moda, vestidos,mujer, moralidad.

ABSTRACT: This paper studies the discourses about fashion and luxury appeared in the Spanish press (especially in the religious press) between the late eighteenth century and the nineteenth century in order to understand what reasons were indicated to control the external appearance. Thus, elements such as morality, economy or the negative results caused in women and the family, have been the main topics discussed through newspaper articles.

KEY WORDS: press, fashion, dresses, woman, morality.

“¿Qué es la moda? La moda es un capricho de un individuo al cual se sujeta la sociedad. Es a veces, una ridiculez que hace ridículo al que no la sigue. Es una extravagancia, una locura, que hace parecer loco y extravagante al que no se somete a ella. La moda es, por decirlo así, el más bárbaro de los progresos; es el progreso de la materia"'.

\footnotetext{
${ }^{1}$ La Paz, $\mathrm{n}^{\mathrm{o}} 2543,31$ de octubre de 1865, Murcia.
} 
El párrafo que abre este artículo, extraído del periódico $\mathrm{La} P a z$, es muy significativo de la mayor parte de los discursos que se articularon en la prensa española en relación a cuestiones como el lujo y la moda. Así, lo que se denota con su sola lectura es el tinte negativo que se le otorgaba a estos elementos. Nada bueno podía traer la moda, si se hablaba del parecer, el individuo parecería ridículo, loco o extravagante.... En definitiva, lo que se quería transmitir era el aviso contra lo que se escondía detrás de ella y que el texto bien definía: era el peor de los progresos y el triunfo de lo material, algo que estaba muy alejado de lo espiritual. Por tanto, la moda, que era un acicate para lo terrenal y para el cuerpo, debía controlarse, no podía dejarse al libre albedrío.

Este trabajo pretende investigar cómo se trató el tema de la moda y la apariencia externa en la prensa española, especialmente en aquella que se publicó desde finales del siglo XVIII y durante el siglo XIX. Asimismo, y teniendo en cuenta la variedad ideológica y temática que esta fuente recoge durante la época tratada, interesa comprender qué opinaba sobre estos temas el discurso eclesiástico y, en menor medida, el pensamiento ilustrado (que tuvo su expresión también en el siglo posterior). En todo caso, lo que se quiere estudiar es la razón de ser de todos estos mensajes: qué argumentos se utilizaban para exponer el gasto excesivo que estas modas implicaban, cómo criticaban la compra de vestidos y adornos, qué elementos usaban para enfrentarse a estas prácticas y cuáles eran los peligros que se derivaban de estas acciones. En muchos casos, y como se quiere demostrar en esta investigación, se exponía que el gusto por las modas y por los lujos excesivos, comportaba la decadencia moral de la sociedad y de la familia; así como todo un conjunto de problemas económicos que empobrecían desde el individuo particular hasta al conjunto de la nación.

Siguiendo la línea anteriormente expuesta, se querían relacionar todas estas temáticas de forma directa con la mujer. De ella se dirá que era la persona ideal para verse influida y perjudicada por ese gusto por la apariencia externa. De ahí que muchos de estos artículos se dedicarán a criticar y denunciar la costumbre del sexo femenino por ocuparse de estos menesteres. Pero, ¿por qué ese ataque al lujo y a la moda en relación con la mujer? ¿Qué fin se perseguía con estos argumentos? El objetivo no podía ser otro que crear unas determinadas pautas de comportamiento que debían seguir las féminas, directrices que finalmente ayudarían a consolidar unas determinas normas de consumo. Evidentemente, todos estos planteamientos teóricos tendrían una desigual recepción y asimilación en el tejido social -en función de diversos factores-, lo que necesariamente implicaría patrones de aceptación y resistencia al modelo 
propuesto desde la prensa.

Hay que destacar también que los discursos que atacaban al lujo, a la moda y a la apariencia externa no eran nuevos, pues habían tenido una amplia tradición en la tratadística, en la ideología eclesiástica anterior y en el imaginario de muchas de estas gentes. Así, el lujo y la moda, en tanto que exponentes privilegiados del dominio de lo mundano, siempre habían sido enemigos de la religión, pues la Iglesia había defendido la idea de que estos componentes suponían un claro peligro para la vida familiar, para la economía nacional y para la moral pública ${ }^{2}$. Junto a los eclesiásticos, los pensadores ilustrados, por ejemplo, también manifestaron un conjunto de ideas que estaban en cierta sintonía con las que exponía el mundo religioso.

Como fuente para el análisis de estos discursos, se va a utilizar la prensa, pero no como objeto de estudio en sí mismo, sino de los mensajes que ésta contenía y que se expresaban hacia el conjunto de la sociedad. De hecho, la validez de la prensa a la hora de enfocar estudios de Historia Social está más que sobradamente demostrada, como así lo dejó patente Casey en su acertado análisis sobre la familia a través de la literatura ${ }^{3}$. De hecho, como propone Pelaz López, para conocer mejor cualquier etapa de la historia, resulta importante tener en cuenta el papel que ejercen los medios de comunicación y, por extensión, la consiguiente creación de diversas corrientes de opinión ${ }^{4}$.

A tenor de todo lo anterior, se trata de insistir en la visión que sobre la apariencia externa se manifestó desde la prensa española, analizando como estos discursos se lanzaban hacia la sociedad con el objetivo de construir, para a la vez controlar, la opinión pública 5 .

\section{LOS PELIGROS PARA LA MORAL Y PARA LA ECONOMÍA}

Desde el Antiguo Régimen, y hasta bien entrada la Edad Contemporánea, se produjo una auténtica invasión y control de la vida privada de los individuos con el fin

\footnotetext{
${ }^{2}$ Una perspectiva muy novedosa sobre el tema, que aúna el estudio de lo cotidiano y de la cultura material desde la óptica de la Historia Social, se encuentra en M. GARCÍA FERNANDEZ (2013). Cultura material y vida cotidiana moderna: escenarios. Madrid: Sílex. ${ }^{3}$ J. CASEY (1990). Historia de la familia. Madrid: Espasa Calpe.

${ }^{4}$ J.V. PELAZ LÓPEZ (2002). Prensa y sociedad en Palencia durante el siglo XIX (1808-1898). Valladolid: Universidad de Valladolid-Diputación provincial de Palencia, p. 68.

${ }^{5}$ Perspectiva que se ha profundizado en F.J. CRESPO SÁNCHEZ (2016). Crear opinión para controlar la opinión. Ideología, sociedad y familia en el siglo XIX. Madrid: Doce Calles.
} 
de orientarla, fundamentándose para ello en una existencia de marcada religiosidad externa y en un gran cuidado de la moral pública ${ }^{6}$. Regulación que sería más notable en el caso de las mujeres que en el de los hombres, por lo que sus trajes, adornos y lujos fueron vistos como elementos claros de inmoralidad manifiesta. Destaca de forma evidente la producción que numerosos obispos y miembros de la Iglesia realizaron sobre este aspecto, más cuando ya eran muy específicos sobre las perversiones y vicios que podían deducirse de los vestidos poco decorosos que usaban las personas ${ }^{7}$. Por tanto, uno de los primeros argumentos que aparecía en la prensa era la vinculación del lujo como el origen de todos los males que asolaban al mundo. Ya fuera a nivel individual o a nivel colectivo, éste solo provocaba los peores resultados y efectos posibles. La corrupción de las costumbres y la inmoralidad que atenazaba a la sociedad tenía su punto de partida en este gusto por la riqueza de lo estético.

Fruto de esa conceptualización que se hacía desde los periódicos, el lujo resultaba dañino para la moralidad y para la sociedad en su conjunto. Uno de los máximos representantes de éste, eran los vestidos y los trajes que las gentes utilizaban para salir a la vía pública y hacer vida social. De estos se decía que no debían ser exagerados o recargados, que había que evitar los adornos y todo aquello que provocara la ostentación. Además, la vanidad y la imitación traían consigo otros defectos para el individuo, pues cada vez trataría de vestir mejor y perfeccionar su imagen, generando un culto excesivo al adorno del cuerpo y un amor propio que derivaría en el egoísmo. Por tanto, se construía un discurso que presentaba el lujo como la llave que abría la puerta hacia un conjunto de vicios que afectarían negativamente a la persona.

"El lujo es la peste de los individuos, la peste de los Estados,
la peste del género humano. Es la causa de todos los males
morales que hay en el mundo, y me atrevo a decir que de
todos los males que llaman fisicos. El lujo nos hace débiles,
enfermizos desde el momento mismo de nuestra
generación...Cuanto a los males morales, ¿quién es quién

\footnotetext{
${ }^{6}$ A. PEÑAFIEL (2005). "Costumbres, moral, fieles y clero en la Murcia del Obispo Belluga", Anales de Historia Contemporánea, 21, pp. 201-202.

${ }^{7}$ Ejemplo paradigmático sería el cardenal Belluga quien, a comienzos del siglo XVIII, dedicó todas sus energías intelectuales a su condena: L. BELLUGA Y MONCADA (1722). Contra los trajes y adornos profano en que de doctrina de la Sagrada Escritura, Padres de la Iglesia, $y$ de todo género de escritores, y razones teológicas se convence su grave malicia, donde se dan doctrinas importantísimas y trascendentales contra todo género de vicios muy útiles para predicadores, y confesores, y para todos los fieles. Murcia.
} 
puede dudar que todos nacen del lujo? Destiérrele Vm. del mundo; y se desterrarán con él aquellos errores, tanto peores, cuanto nacen de la corrupción de lo muy bueno, a saber de las ciencias y las artes"

Este artículo de El Censor exponía tanto los males físicos como los problemas morales que ocasionaba el lujo. A pesar de que no se trataba de un periódico de inspiración religiosa, desde sus páginas se reprodujo casi sin variar el tradicional discurso que sobre esta cuestión se había ido construyendo. Esto puede indicar que era una temática que no solo preocupaba a los sectores de la Iglesia, sino también a otros grupos presentes en la sociedad y en la prensa. Aunque en otras entregas de esta publicación se introdujeron disertaciones que sí que defendían determinadas formas de lujo que supuestamente no entraban en conflicto con la moral o no perjudicaban a la economía nacional, lo normal fue que de primera mano se diera una visión que no se mostraba de acuerdo con los efectos que éste traía consigo. Así, este periódico definirá el lujo como un goce excesivo de las cosas, especialmente de aquellas que traían consigo la consecución de un alto grado de confort y que, por tanto, no eran necesarias para la vida normal de las personas. Además, señalaba que otro elemento negativo era que el fenómeno de la moda no solo se quedaba en los trajes, vestidos y complementos, sino que cada vez se manifestaba de forma más amplia y aumentando su círculo de influencia, afectando a todos los órdenes de la vida cotidiana y reproduciéndose exponencialmente ${ }^{9}$. Todo ello estaba destinado, como no podía ser de otra manera, a la ostentación, es decir, a fijar la identidad a través de la apariencia y la representación. De ahí que se diera esa imagen condenatoria de lo que la moda y el lujo suponían a efectos prácticos. Siguiendo con este fragmento que se reproduce, se puede pensar que la referencia que realiza sobre los problemas físicos ocasionados parece exagerada a todas luces. En todo caso, lo que denota es una construcción argumental que se sustenta sobre la posición contraria asumida y que trata de marcar los ejes de pensamiento y actuación con respecto a estos menesteres. De otro lado, la relación que ya establece entre lujo y moralidad como elementos en clara antítesis, queda expuesta en este primer acercamiento al tratamiento que sobre estos elementos se hacía en la prensa de finales del siglo XVIII y del siglo XIX.

En este sentido, vestir a la moda era comparable a querer ser vanidoso, por lo que

\footnotetext{
${ }^{8}$ El censor, $\mathrm{n}^{\mathrm{o}} 133,30$ de noviembre de 1786, Madrid.

${ }^{9}$ D. PÉREZ ABRIL (2009). "Lujo, moda y modernidad en la prensa española del siglo XVIII". Res publica, 22, pp. 249-256.
} 
había que evitar cometer esta falta moral. Como proponía Deslandres en sus investigaciones, la vestimenta representa un importante corpus que puede proporcionar información sobre la relación directa de los individuos con su contexto social y con su posición en el mismo ${ }^{10}$. Ante esto, lo que también preocupaba a la Iglesia, más allá de los efectos morales de la moda, era la confusión social que podían ocasionar los ropajes y los atuendos, pues, una vez más, habría personas que tratarían de aparentar lo que no eran, sino lo que querían $\operatorname{ser}^{11}$. Para estos eclesiásticos, la emulación que desde las clases inferiores se llevaba cabo constituía un auténtico problema, pues la señalaban como una de las causas del desorden social que podía ocasionar el desgaste de las bases teóricas y de los pilares que sustentaban el modelo organizativo del Antiguo Régimen. Estas clases bajas, que copiaban modelos y comportamientos, corrompían así la moralidad y cometían "una forma de pecado, una rebelión e insubordinación contra el orden del mundo" 12 .

A pesar de que los periódicos estaban de acuerdo con la idea de que las modas habían existido de forma continua a lo largo de la historia, lo que muchos señalaban era que nunca se habían hecho tan tangibles y peligrosas como en el momento que les había tocado vivir. Esa era la propuesta que lanzaba el Diario de Madrid, pues aunque admitía su prolongada presencia, mostraba cómo la solución ideal era desterrar todos estos elementos de la vida cotidiana, pues así se podrían prevenir los males que de las modas se derivaban. Basándose en ese fundamento teórico, en esa condena tácita si se quiere, el artículo pudo desarrollar todo un alegato que explicitaba las razones por las que se debía proceder en contra de la propagación y desarrollo de estas costumbres. La moda era engañosa y ladina, pues una de las peores características que presentaba era que podía hacer que la persona cometiera faltas sin que ésta terminara de darse cuenta, podía esconder sus excesos y hacerlos pasar con normalidad:

"La pompa en que se recrea la vista con el exceso de trajes, siempre ha sido engañoso lucimiento en que se disfrazan graves daños contra la sociedad, y que lentamente la llevan a su ruina. Sujetas éstas a desvanecerse las cosas humanas, pero ningunas más que aquellas que todo es vanidad, y

${ }^{10}$ Y. DESLANDRES (1988). El traje, imagen del hombre. Barcelona: Tusquets.

${ }^{11}$ Como ha expresado García Fernández, se podía identificar la posición social a partir del atuendo; M. GARCÍA FERNÁNDEZ (2008). "Percepciones de la apariencia castellana dentro de España y en Roma: imagen, cultura material y estilos de vida comparados a finales del Antiguo Régimen". Cuadernos Dieciochistas, 9, pp. 119-151.

12 D.R. SLATER (1997). Consumer culture and modernity. Cambridge: PolityPress, p. 69. 
engañan en la costumbre, porque como se usa no causa novedad: viene envuelta la corrupción en el traje sin sentirse... Es verdad que todos tiempos y edades, después que prevaleció la malicia, ha habido lujo y corrupción; pero es verdad también que nunca ha trascendido ni hecho estragos en la plebe como ahora",13.

El discurso eclesiástico con respecto a estos temas fue muy claro en todo momento: el lujo y la moda eran el origen de la maldad y de los vicios. Todo lo que estuviera relacionado con estos era un acicate más para conseguir la corrupción moral de la sociedad. Buena muestra de ello lo exponía el siguiente ejemplo, perteneciente a la publicación Atalaya de La Mancha en Madrid. En esa necesaria convergencia que realizaba el periódico entre los intereses de la monarquía absoluta de Fernando VII y los valores más tradicionales ${ }^{14}$, que eran los defendidos por la Iglesia, mostraba cómo era necesario que con el regreso del monarca se volviera a contener el lujo que había sacudido al país durante esos años de desidia de los gobernantes y de invasión francesa. Para ello, en uno de sus artículos mostraba una especie de memorial en el que recogía los puntos que deberían acometerse para que España regresara a la buena senda y fuera acabando con los problemas morales que la acuciaban. Así, en el cuarto punto que presentaba, se hacía eco de los males que el lujo había ocasionado a los españoles, diciendo de éste que era uno de los peores enemigos contra los que podía enfrentarse la religión y la sociedad. Lo importante era corregir los errores y mantener las buenas costumbres anteriores a la invasión, por lo que era misión de estos dirigentes determinar en qué condiciones el lujo podía ser admisible, eliminando el resto de componendas que eran las que perjudicaban al entramado de las conciencias y de las conductas. Esta publicación, al tiempo que criticaba las acciones de los liberales y elogiaba los principios absolutistas del régimen, exponía la necesidad de reformar la forma de entender el lujo, volviendo a las concepciones anteriores:

"Cuarto, siendo tan pernicioso el lujo desmedido, manantial el más fecundo de la molicie, de los placeres y de la disipación, juzgaba yo también que era de su deber el no cesar de reclamar con el mayor vigor y energía contra los abusos que pueden contribuir a su aumento después de una

\footnotetext{
${ }^{13}$ Diario de Madrid, $\mathrm{n}^{\circ}$ 135, 15 de mayo de 1797, Madrid.

${ }^{14}$ Una obra fundamental para entender el ambiente periodístico de la etapa es J.F. FUENTES y J. FERNÁNDEZ SEBASTIÁN (1992). Historia del periodismo español. Prensa, política y opinión pública en la España contemporánea. Madrid: Síntesis.
} 
época de desolación ..., y analizando hasta qué punto, en qué términos, y en qué cosas puede tolerarse el lujo sin riesgo de la ruina de las buenas costumbres" $" 15$.

Frente a las maldades y pecados que provocaban estos vestidos, trajes y adornos, el cuerpo eclesiástico siempre manifestó su seguridad y convencimiento en que los valores cristianos podían combatir y evitar los efectos pecaminosos que estos provocaban.

Resulta muy interesante la comparación que realizaba el periódico La Época, pues ofrecía una imagen muy didáctica y comprensible de lo que suponía la moda para el hombre. Decía que el ser humano era comparable con los pavos reales cuando se dejaba llevar por ésta, pues muchas veces se esforzaba en demasía por tratar de hacer gala de sus vestimentas para exhibirse y llamar la atención de los demás, como así ocurría con la función que tenía el vistoso plumaje de estas aves. Al fin y al cabo, éstas eran cuestiones menores en las que no había que invertir tanto tiempo y dedicación, más cuando podían distraer en el cumplimiento de las obligaciones religiosas y morales.

Al mismo tiempo, en esta interpretación se señalaba otro problema que se deslizaba de esta forma de entender el lujo, pues el individuo trataría cada vez de trabajar más para obtener mayores beneficios económicos, pero no para mantener o cuidar a su familia, sino para tratar de emular el modo de vida y la apariencia de las personas que le rodeaban. Todo ello provocaba una confusión de las prioridades que toda persona tenía que tener en la vida, entrando en una espiral que solo resultaba perjudicial para la moralidad. Era un discurso condenatorio que no presentaba fisuras a la hora de posicionarse frente a estas cuestiones, un sólido mensaje que además se nutría de razones de índole social y económica para reforzar sus argumentaciones. Insistiendo una vez más en la falsa imagen que provocaban todas estas prácticas, se promocionaba la idea de que todo ello generaba un reflejo deformado de lo que realmente era la sociedad y de los individuos que la integraban. Como se viene mencionando, esta construcción teórica tenía una gran influencia de la concepción que de la moda se tenía en estos momentos, pues se la relacionaba directamente como un símbolo de la clase y la posición, es decir, como un indicador manifiesto del status socia ${ }^{16}$. Elemento éste

${ }^{15}$ Atalaya de La Mancha en Madrid, $\mathrm{n}^{\mathrm{o}}$ 18, $3^{\mathrm{a}}$ época, 27 de febrero de 1815, Madrid. ${ }^{16}$ L. GONZÁLEZ DÍEZ y P. PÉREZ CUADRADO (2009). "La Moda elegante y el Correo de las Damas, dos publicaciones especializadas en moda en el siglo XIX”, Doxa comunicación, 8, p. 54. 
claramente expuesto en el periódico:

"Si la moda y la corrupción dicen que el hombre ha sido hecho únicamente con el mismo objeto que el pavo real, para hacer la rueda para brillar, la moral eterna del mundo cree y creerá que ha sido formado para trabajar y para pensar... Cuando el lujo se desenfrena y se desborda, una nueva etiqueta clasifica a la sociedad, no en razón de la probidad, sino a la representación; cada uno procura, a toda costa, más parecer que ser, y trabajar para igualar, cuando menos en asemejarse a su vecino" ${ }^{17}$.

Más allá de las cuestiones morales que los textos mencionaban, otro de los elementos que se pretendió conseguir fue la creación de una opinión muy concreta con respecto a estos temas. La prensa que protagonizó el panorama informativo de finales del siglo XVIII, y más tarde en la centuria siguiente, trató de manifestar un discurso que poco tenía de favorable con respecto a la moda, ya que insistía en la idea de que ésta perjudicaba a los intereses de la Nación. Esta teoría se basó en dos líneas argumentales bien definidas. De un lado, apelando a los sentimientos patrióticos, se criticaba la llegada de modelos e influencias estéticas desde el extranjero, especialmente los procedentes de Francia, pues ocasionaban el desprestigio de lo que era considerado como lo español y lo tradicional. Por otra parte, se exponían los problemas económicos que todo esto ocasionaba al erario público, ya que se producía la salida de capitales hacia el extranjero para la compra de géneros y materiales mientras que se perjudicaba a los artesanos nacionales. Así, unido a la crítica ante los peligros que suponía para la moralidad y la decencia, discurso más típico de los sectores religiosos, se anexaron otras argumentaciones que se centraban más en los aspectos económicos y sociales, cuestiones que en cierta medida fueron promovidas por algunos pensadores ilustrados ${ }^{18}$. Toda una convergencia de factores e intereses que dieron lugar a una posición muy concreta con respecto a estos asuntos.

Junto al tema de la patria, y en directa relación con éste, se encontraba la cuestión del dinero y de los gastos que el seguimiento de las modas y de los artículos de lujo llevaba consigo. Se consideraba que este tipo de actitudes perjudicaban a la economía de España, pues el gusto por las telas y las modas extranjeras provocaba numerosos

${ }^{17}$ La Época, $\mathrm{n}^{\circ}$ 6382, 1 de octubre de 1868, Madrid.

${ }^{18}$ Esta fue una de las pretensiones de algunos ilustrados españoles: J. SARRAILH (1978). La España ilustrada de la segunda mitad del siglo XVIII. México: Fondo de Cultura Económica. 
dispendios que no repercutían en el bienestar de la economía nacional. A pesar de las pragmáticas promulgadas para evitar esto, los textiles extranjeros, en especial los franceses, seguían teniendo un gran protagonismo en la confección de vestidos ${ }^{19}$. En todo caso, lo que se estaba sugiriendo era que las acciones de estas personas provocaban una salida de capitales hacia el extranjero, impidiendo que estos emolumentos pudieran ser utilizados para potenciar diversos aspectos que podían beneficiar al país. De forma sarcástica, el siguiente artículo reproducía las palabras de un petimetre que hablaba sobre la buena misión que estaba cumpliendo hacia el Estado al liberarle de ese dinero innecesario ${ }^{20}$, pasando esa pesada carga a otras naciones:

"Nuestra conducta es útil al Estado; pues además de conseguir el descargar a España del peso del dinero que la oprime para repartirlo a otros reinos que nos proveen de tantas bagatelas, contribuimos a sostener el lujo... y aunque es cierto, que pudieran estas emplearse en los ejércitos, en el cultivo de los campos, y en las fábricas, $y$ artes verdaderamente útiles al Estado... "2l.

Esta visión que ofrecía el periódico no era novedosa, y tampoco lo era esa apelación a la intervención de los poderes públicos en el asunto, pues ya desde finales del siglo XVI se habían realizado numerosas críticas contra el lujo en la indumentaria y en los adornos, demandando medidas legislativas que contuvieran esos excesos a través de la creación de leyes suntuarias al respecto ${ }^{22}$.

No sólo se quedaba ahí el discurso, sino que además se prestaba atención directa a las personas adineradas que podían permitirse esta forma de vida, es decir, que tenían acceso de forma fácil a este tipo de productos:

"Más, ¿Qué responderán a ellas tantos otros, que se glorían del nombre de Patriotas, sin pensar si quiera en alargar la

19 E. MARTÍNEZ ALCÁZAR (2007-2008). "Características del atuendo español del setecientos a través de la documentación notarial de Murcia”. Imafronte, 19-20, pp. 177-193. ${ }^{20}$ A este respecto, resulta interesante la consulta de F.J. CRESPO SÁNCHEZ (2015). "La imagen del petimetre en la prensa española de finales del siglo XVIII". En Labrador Arroyo, F. (ed.). II Encuentro de Jóvenes Investigadores en Historia Moderna. Líneas recientes de investigación en Historia Moderna. Madrid: Universidad Rey Juan Carlos, ediciones cinca, pp. 1295-1312.

${ }^{21}$ Correo de Murcia, ${ }^{\circ}$ 16, 23 de octubre de 1792, Murcia.

${ }^{22}$ Para un acercamiento al tema se puede consultar M. GARCÍA FERNÁNDEZ (2002). La economía española en los siglos XVI, XVII y XVIII. Madrid: Actas; A. GIORGI (2013). De la vanidad y de la ostentación. Imagen y representación del vestido masculino y el cambio social en España, siglos XVII-XIX. Tesis doctoral defendida en la Universidad de Murcia. 
mano para estorbar los daños que a todos nos amenazan? Si es tan fuerte el pernicioso ejemplo de la moda, del lujo, de la disipación, de la avaricia, porqué no se rendirán tantos ricos a estos poderosos ejemplares de patriotismo, en vez de aplicarse, con la máscara del bien público, a engrosar sus caudales, y gravar a los infelices" $" 23$.

Por tanto, se criticaba a las personas que mantenían una vida de exceso y lujo, ya que se consideraba que los individuos que gozaban de una mayor capacidad económica debían ayudar a conseguir el bienestar de sus congéneres y por ende del país; discurso que, como muchos otros que se han señalado, se encontraban ya en épocas anteriores y tuvieron un largo recorrido informativo.

\section{LA MUJER, LA FAMILIA Y LA MODA}

Junto a todo lo anterior, también se hizo hincapié en los malos efectos que las modas y el lujo ocasionaban en la familia y muy especialmente en la mujer ${ }^{24}$. De hecho, se consideraba que estas prácticas repercutían muy negativamente en la institución familiar porque suponían el gasto del dinero que debía estar destinado a su manutención y supervivencia, más cuando se trataban de individuos de las clases más desfavorecidas. Una de las consecuencias que provocaba era el abandono de los niños, pues esas ansias de aparentar y de querer vestir a la moda, generaban una severa distracción de los recursos que acababa dilapidando las rentas de las familias. Frente a este dramático cuadro, la Iglesia proponía que el ahorro era el valor principal que debían seguir las familias, pues tenía que convertirse en uno de los pilares básicos sobre el que debía sostenerse esa pequeña comunidad. Faceta que no solo tenía que ser practicada por la madre, que era la encargada de la organización del hogar, sino por todos los miembros de éste. No obstante, y a pesar de esos mensajes que pretendían llegar también a los padres e hijos, en los diferentes periódicos se relacionaba de forma más directa a la mujer con esa cualidad, objetivo que solo podría conseguir si se mantenía en el hogar, meditaba muy bien los gastos que debía realizar y si no se dejaba llevar por la compra innecesaria de adornos y de vestidos. Era una imagen que colocaba a la mujer como la salvaguarda de la economía familiar, pues debía administrar el dinero que el marido llevaba a casa con su trabajo. Al mismo tiempo,

${ }^{23}$ Correo de Murcia, $\mathrm{n}^{\text {o }}$ 59, 23 de marzo de 1793.

${ }^{24}$ Se puede realizar un primer acercamiento en: R. DE LA PUERTA ESCRIBANO (19961997). "Moda, moral y regulación jurídica en la época de Goya", Ars Longa, 7-8, pp. 205-217. 
estaría así mostrando un adecuado comportamiento moral para consigo misma y para con los demás, dando ejemplo a su prole y a la sociedad.

Por todo ello, según estos escritores, defectos como la coquetería, la vanidad o el capricho debían ser desterrados de la vida de las mujeres, más cuando la propia Iglesia los había condenado sin paliativos. Eran una fuente de la que solo emanaban pecados y errores. El gusto por el lucimiento del cuerpo produciría solamente gastos, ruinas y libertinajes ${ }^{25}$. El decoro, la contención y la humildad debían ser las señas unívocas de identidad de la mujer cristiana, más cuando éstas podían suponer un peligro para la decencia de aquellas personas con las que en ocasiones debían compartir espacios, ya fueran públicos o privados. Cuando la mujer se presentaba en sociedad estaba en juego la moralidad de sus congéneres, por lo que no debía cometer excesos que pudieran llevar a estos a alimentar sus pensamientos y acciones pecaminosas e impuras. Ya fuera a través de su misión para con la familia o para dirigir su propia conciencia ante los vicios y defectos, la mujer siempre debía tener cuidado con las tentaciones del lujo y de la moda, pues sus efectos perniciosos estaban siempre al acecho:

"Nos referimos al lujo; aludimos a la corrupción que revela; hablamos de la horrible farsa que representa. ¿Qué dique habrá de contenerlo? ¿Qué corriente será bastante poderosa para contrarrestar la de sus inmoralidades?... Si antes de presentarse el lujo en el seno de las familias se midieran sin engaño las proporciones de la fortuna y no se le permitiese traspasarlas, lejos de seguir sus huellas el desorden, la farsa, la corrupción, el crimen, habian de acompañarle el plácido bienestar" ${ }^{26}$.

En la relación que se presentaba entre las mujeres y las modas, una vez más se apelaba a esa supuesta debilidad de la que eran víctimas las féminas, pues era una parte intrínseca de su naturaleza. Frente a los numerosos cambios que sufrían los estilos y las formas de vestir, las mujeres se verían desprotegidas y sin fundamento para poder hacer frente a semejantes gastos. No solo había que tener en cuenta la vestimenta, sino que los adornos, los peinados y otros complementos también iban variando en función de las directrices de cada momento, cuestión que incrementaba, según los periódicos,

${ }^{25}$ El desprecio del cuerpo fue un argumento constate para el pensamiento eclesiástico como se ha comentado en P. ARIÉS y G. DUBY (1991). Historia de la vida privada. La Revolución francesa y el asentamiento de la sociedad burguesa. Madrid: Taurus.

${ }^{26}$ La juventud católica de La Habana, año II, nº 7, 14 de abril de 1872, La Habana. 
el despilfarro monetario. De esta forma, lo que se señalaba era que la inconstancia era una cualidad común tanto a las modas como a las mujeres. Unido a esa idea, estaba la extendida consideración peyorativa que se tenía hacia oficios como el de sastre o peluquero, de los que se decía que engañaban a las mujeres para obtener de ellas los máximos beneficios posibles. Junto a la debilidad y la inconstancia, la ingenuidad se conformaba como el tercer vértice que caracterizaba esa descripción. Al margen de reprimir comportamientos, lo que también se quería potenciar era la advertencia frente a los posibles abusos que estos embaucadores de la moda podían proferir. Aviso que no solo se destinaba al sexo femenino, sino que también se dirigía a los maridos que debían corregir y vigilar a sus esposas.

Se señalaba, además, la mala costumbre de las mujeres que dedicaban un tiempo excesivo a arreglarse y emperifollarse delante del tocador, pues esto sustraía tiempo a sus verdaderas obligaciones como hija, esposa o madre ${ }^{27}$. A pesar de estos discursos que aparecían en una parte de la prensa, hay que indicar que ya desde el siglo XVIII, y más intensamente en el siglo XIX, existieron multitud de publicaciones destinadas a la lectura femenina que ya incluían sus propias secciones sobre modas. Incluso llegaron a publicarse revistas que estaban especializadas y se dedicaban en exclusiva a estas cuestiones, incluyendo figurines y patrones para que las propias mujeres pudieran confeccionar sus vestidos. Así, se puede decir que fue hacia 1820 cuando se produjo en España la verdadera eclosión de estas publicaciones en lo que a su llegada al público se refiere. ${ }^{28}$ Aparecen periódicos como El Periódico de las Damas, La moda elegante, El Correo de las Damas, El Tocador o La Luna, algunos de los cuales tendrían cierta longevidad.

Como se puede comprobar, el tratamiento de la moda en la prensa tuvo una vertiente que se puede calificar de ambigua, pues mientras que la Iglesia católica condenaba estas prácticas, otros sectores no dudaron en defenderlas y promocionarlas, siempre dentro de unos límites y con unas motivaciones específicas. En todo caso, desde el sector religioso la idea que se tenía que transmitir a la opinión pública estaba muy clara desde el principio, junto a todos los problemas morales que producía el lujo,

27 M.A. CANTERO ROSALES (2007). "De 'perfecta casada' a 'ángel del hogar' o la construcción del arquetipo femenino en el XIX". Tonos. Revista electrónica de estudios filológicos, 14. http://www.um.es/tonosdigital/znum14/secciones/estudios-2-casada.htm. [Consultado: 12-08-2016].

${ }^{28}$ P. PENA (2001). “Análisis semiológico de la revista de modas románticas”. Estudios sobre el mensaje periodístico, 7, pp. 365-381. 
gastar dinero de forma indiscriminada en todos esos artículos se convertía también en un punto de tensión para los presupuestos familiares ${ }^{29}$. Todas estas argumentaciones y matices inspiraron muchos de los mensajes que aparecían en la prensa:

"Éstas son tan variables como las bellas: unas y otras están
sujetas al capricho y entrambas sometidas a influencias
extrañas... Las modas varían con las estaciones, al menos
que no plazcan en los intermedios algunos adefesios de los
que nos regalan mensualmente nuestros ilustrados
vecinos... Pero si es verdad que una parte de la sociedad se
ocupa tan solo de estas fruslerías ridiculas, pasando su vida
en el tocador para hacerse la interesante en el estrado y
paseo",30.

Esos eran los males denunciados y los peligros a combatir, pero la prensa también prestaba atención a las posibles soluciones y contenciones que podrían llevar a cabo los buenos cristianos; al margen de la acción que debían emprender los dirigentes para regular el gasto en productos suntuarios. Ya se ha comentado que el ahorro era propuesto como uno de los grandes baluartes para luchar contra la moda y la inmoralidad que ésta provocaba. Lo importante era conseguir que este mensaje calase en el seno de la sociedad y terminara convenciendo a la opinión pública de la necesidad de su interiorización como modelo de conducta ante el consumo. Este propósito se trató de conseguir, una vez más, mediante la inserción de cuentos moralizantes que perseguían transmitir buenos ejemplos con la intención de que estos fueran el modelo a imitar por las personas que tenían acceso a la información contenida en el periódico.

En este caso se centraba la atención en una familia de la clase acomodada y que gozaba de una vida desahogada desde el punto de vista económico (estereotipo idílico del que gustaban muchos estos autores). La hija, que había sido totalmente malcriada por su padre, siempre hacía gala de los mayores despilfarros y de gastos superfluos, no practicando la virtud del ahorro y no mostrando ningún tipo de preocupación por esto. En una ocasión, cuando la niña quiso ayudar a una familia necesitada, se encontró con el problema de que no tenía dinero para socorrerlos. Ante esta situación, alarmada por la falta monetaria, la hija corrió rauda a contar a su madre la mala experiencia que

${ }^{29}$ M.J. MAYNES (2002). "Culturas de clases e imágenes de la vida familiar correcta". En Kertzery, D. y Barbagli, M.. (comps.). Historia de la familia europea. La vida familiar desde la Revolución Francesa hasta la Primera Guerra Mundial (1789-1013), volumen 2. Barcelona: Paidós, pp. 297-340.

${ }^{30}$ La estrella, $\mathrm{n}^{\mathrm{o}} 28,15$ de enero de 1843 , Cádiz. 
había vivido y la sensación desoladora que le había provocado no poder aliviar a esta pobre familia. La madre, y he aquí la moraleja de la historia, enseñó con ese pretexto a la hija la importancia del ahorro. Además, para que aprendiera cómo debía realizarlo, la progenitora contó a su hija como ella, sin que lo supiese nadie, había desoído las numerosas peticiones y caprichos que ésta le hacía, evitando muchas compras y guardado todo ese dinero. Gracias a ese saludable hábito, la madre había conseguido ahorrar gran parte del dinero que le había sido asignado a la niña, por lo que pudo ofrecérselo para lograr así ayudar a la familia necesitada. Con el paso del tiempo, seguía contando el artículo, estas personas consiguieron mejorar su situación y acabar con su pobreza, pues la limosna que esta chica les había entregado había sido el primer paso para terminar con su nefasta situación. La protagonista de la historia, conmovida por su gesto y por lo que éste había conseguido, cambió radicalmente su forma de ser, controlaba más sus gastos y siempre ahorraba algo del dinero del que disponía. Esa era la gran enseñanza moral que se desprendía de este relato, el buen ejemplo y los consejos de la madre habían conseguido operar un cambio significativo en el comportamiento de su hija. Al mismo tiempo, ese ahorro se convertía en un acicate más para la práctica de la beneficencia ${ }^{31}$, elemento que resultaba verdaderamente importante a la hora de confeccionar los modelos morales pretendidos por la Iglesia. La narración terminaba señalando:

"Pero se hizo menos descuidada, se sometió sin violencia a las observaciones de su madre, reconoció que la sencillez del buen gusto es preferible al lujo mal entendido, y estableció en su tocador y equipaje el orden aconsejado por la previsión. En vez de gastar a diestro y siniestro, echaba sus cuentas, y dejaba de comprar las cosas inútiles que en ciertos momentos producen un disgusto" 32 .

Otro de los recursos utilizados, junto al que se ha visto más arriba, era la inserción de noticias en las que destacados personajes mostraban su disconformidad para con las modas y el lujo. Ésta era una forma más de transmitir modelos de comportamiento que debían ser aprehendidos por los individuos. Esa inquietud se reflejaba muy en la publicación La bandera católica, que en uno de sus números anunciaba como la Emperatriz de Alemania, junto a otras distinguidas mujeres de su país, había procedido a la creación de una

31 En la época ya se reconocía la diferencia entre la beneficencia privada y pública; A. MORELL (2012). La legitimación social de la pobreza. Barcelona: Anthropos, p. 113.

${ }^{32}$ El Correo de la Moda, $\mathrm{n}^{\circ}$ 25, 1 de noviembre de 1852, Madrid. 
asociación cuyo objetivo era luchar contra los excesos. De esta forma, se mostraba como una mujer de alta alcurnia, que podía estar rodeada de los vestidos y adornos de los que gustara, había entendido lo perjudicial que podían traer consigo estos gastos, decidiéndose así a actuar de forma contundente. Destacando la procedencia social de esta señora, se creaba un patrón que podía ser fácilmente imitado por el resto de mujeres. Al mismo tiempo, el artículo también tenía tiempo de centrar su atención en el sexo masculino, pues indicaba como el emperador evitaba el lujo y los desfases a toda costa. Así, había dado órdenes para que éste fuera contenido tanto en sus ejércitos como en su cuerpo de funcionarios. Todas estas argumentaciones tenían una clara misión: evitar los desordenes sociales que podían llegar a producirse. Se entendía que las diferencias en el ritmo de vida entre los sectores sociales, unido al lujo con el que disfrutaban las clases acomodadas, podían ocasionar envidias y malestar a los más desfavorecidos. Incluso, podían ser el inicio de revueltas y levantamientos. La contención del exceso era, a la vez, la contención de la conflictividad social. Como indicaba el artículo, lo que se debía hacer en España era tomar conciencia de este ejemplo que recogían, e imitarlo en la medida de lo posible, pues solo así se podrían prevenir los males que el lujo ocasionaba en la sociedad y en la familia:

"Pretenden con sobrada razón que el lujo desenfrenado de nuestros días es un mal social de primer orden, que solo sirve para excitar el odio de las clases pobres contra las clases acomodadas. iQué bien nos vendría si sucediera lo mismo en nuestra querida España, y se destinara lo que se derrocha en lujo, al alivio de esas desdichadas clases que depondrian sus envidias y sus odios y bendecirian sus bienhechores!" 33 .

Por tanto, la moda suscitó todo un conjunto de debates en la prensa que incidieron en muchas ocasiones en las repercusiones morales que ésta traía consigo. Con una visión negativa del tema, siempre se consideró que provocaba la perdición de las costumbres y la adquisición de nuevos comportamientos y conductas que en nada parecían bien a la rígida Iglesia católica o a otras ideologías. La moral, la familia, la mujer y la sociedad estaban en peligro, por lo que una vez más, la pretensión de estas publicaciones fue transmitir un discurso claro, sencillo y que fuera asumido fácilmente por la opinión pública.

\section{CONCLUSIONES}

${ }^{33}$ La bandera católica, $\mathrm{n}^{\circ}$ 19, 3 de agosto de 1893, Cartagena. 
Aunque en este trabajo se han utilizado publicaciones de diversas orientaciones, ha sido el pensamiento religioso el gran protagonista del mismo. Por ello, y como se ha comprobado, estos eran los valores y comportamientos morales que la Iglesia católica quería promocionar e instalar en los individuos que conformaban el cuerpo social. Para ello, una idea siempre estuvo clara, solo la Iglesia podía representar los modelos que eran correctos y beneficiosos, el resto, solo podían estar encaminados a la equivocación y al pecado. El argumentario eclesiástico, con el objetivo de conseguir esta misión, siempre se esforzó en condenar y criticar todos aquellos conatos de modernidad que podían poner en duda la hegemonía religiosa a la hora de influir en las conciencias. Todos estos discursos, indistintamente de la temática que tratasen, se encaminaban a preservar la posición privilegiada de la Iglesia como cabeza visible en la dirección moral de las personas. La creación de la opinión pública pasaba, ineludiblemente, por el diseño de las conciencias.

Pero, ¿por qué este ataque tan desmedido contra el lujo y la moda? ¿Qué fin se perseguía con todos estos discursos? Como se viene exponiendo, el objetivo final de todos estos argumentos fue la confección de un determinado modelo de conducta y de comportamiento, siendo más acusado en este caso para las mujeres, que eran las principales implicadas en este tipo de cuestiones según los propios periodistas. Por tanto, en estos artículos condenatorios, se puede detectar una clara intención de intervenir en el ordenamiento de las vidas y en las formas de actuar. De otro lado, si todo este entramado se analiza en términos de movilidad social, esto puede hacer reflexionar, al mismo tiempo, sobre los intentos de la institución eclesiástica por conseguir el estatismo de los roles femenino y masculino en la sociedad. Todo ello, ha podido comprobarse a partir de dos temáticas muy recurrentes en la prensa: los discursos que censuraban directamente los excesos en vestidos, adornos y modas -con el consiguiente gasto económico que suponían y el problema moral que ocasionaban, y los mensajes que indicaban el especial peligro que suponían para la mujer y para la familia.

Al final, lo que todos estos mensajes y discursos dejaban patente era que la apariencia externa, es decir, el parecer (que era tan importante o más que el ser), siempre preocupó al pensamiento eclesiástico y a otros como el ilustrado. De otro lado, la persistencia de estas temáticas en la prensa en un tiempo largo, tanto a nivel cualitativo como cuantitativo, señalan la verdadera importancia que adquirió este asunto, pues se trató de regular y controlar de diversas formas, siendo la tribuna de la palabra escrita una más de ellas. 


\section{BIBLIOGRAFÍA}

ARIÉS, P. y DUBY, G. (1991). Historia de la vida privada. La Revolución francesa y el asentamiento de la sociedad burguesa. Madrid: Taurus.

BELLUGA Y MONCADA, L. (1722). Contra los trajes y adornos profano en que de doctrina de la Sagrada Escritura, Padres de la Iglesia, y de todo género de escritores, y razones teológicas se convence su grave malicia, donde se dan doctrinas importantísimas y trascendentales contra todo género de vicios muy útiles para predicadores, y confesores, y para todos los fieles. Murcia.

CANTERO ROSALES, M.A. (2007). "De 'perfecta casada' a 'ángel del hogar' o la construcción del arquetipo femenino en el XIX". Tonos. Revista electrónica de estudios filológicos, 14. http://www.um.es/tonosdigital/znum14/secciones/estudios-2-casada.htm. [Consultado: 12-08-2016].

CASEY, J. (1990). Historia de la familia. Madrid: Espasa Calpe.

CRESPO SÁNCHEZ, F. J. (2015). "La imagen del petimetre en la prensa española de finales del siglo XVIII". En Labrador Arroyo, F. (ed.). II Encuentro de Jóvenes Investigadores en Historia Moderna. Líneas recientes de investigación en Historia Moderna. Madrid:Universidad Rey Juan Carlos, ediciones cinca, pp. 1295-1312.

(2016). Crear opinión para controlar la opinión. Ideología, sociedad y familia en el siglo XIX. Madrid: Doce Calles.

DE LA PUERTA ESCRIBANO, R. (1996-1997). "Moda, moral y regulación jurídica en la época de Goya". Ars Longa, 7-8, pp. 205-217.

DESLANDRES, Y. (1988). El traje, imagen del hombre. Barcelona: Tusquets.

FUENTES, J. F. y FERNÁNDEZ SEBASTIÁN, J. (1992). Historia del periodismo español. Prensa, política y opinión pública en la España contemporánea. Madrid: Síntesis.

GARCÍA FERNÁNDEZ, M. (2002). La economía española en los siglos XVI, XVII y XVIII. Madrid: Actas.

(2008). "Percepciones de la apariencia castellana dentro de España y en Roma: imagen, cultura material y estilos de vida comparados a finales del Antiguo Régimen". Cuadernos Dieciochistas, 9, pp. 119-151.

(2013). Cultura material y vida cotidiana moderna: escenarios. Madrid: Sílex.

GIORGI, A. (2013). De la vanidad y de la ostentación. Imagen y representación del vestido masculino y el cambio social en España, siglos XVII-XIX. Tesis doctoral defendida en la Universidad de Murcia.

GONZÁLEZ DÍEZ, L. y PÉREZ CUADRADO, P. (2009). “La Moda elegante y el Correo de las Damas, dos publicaciones especializadas en moda en el siglo XIX”. Doxa comunicación, 8, pp. 53-72. 
MARTÍNEZ ALCÁZAR, E. (2007-2008). "Características del atuendo español del setecientos a través de la documentación notarial de Murcia". Imafronte, 1920, pp. 177-193.

MAYNES, M.J. (2002). "Culturas de clases e imágenes de la vida familiar correcta". En Kertzer, D. y Barbagli, M. (comps.). Historia de la familia europea. La vida familiar desde la Revolución Francesa hasta la Primera Guerra Mundial (1789-1013), volumen 2. Barcelona: Paidós, pp. 297-340.

MORELL, A. (2012). La legitimación social de la pobreza. Barcelona: Anthropos.

PELAZ LÓPEZ, J.V. (2002). Prensa y sociedad en Palencia durante el siglo XIX (1808-1898). Valladolid: Universidad de Valladolid-Diputación provincial de Palencia.

PENA, P. (2001). "Análisis semiológico de la revista de modas románticas". Estudios sobre el mensaje periodístico, 7, pp. 365-381.

PEÑAFIEL, A. (2005). "Costumbres, moral, fieles y clero en la Murcia del Obispo Belluga". Anales de Historia Contemporánea, 21, pp. 201-218.

PÉREZ ABRIL, D. (2009). "Lujo, moda y modernidad en la prensa española del siglo XVIII". Res publica, 22, pp. 249-256.

SARRAILH, J. (1978). La España ilustrada de la segunda mitad del siglo XVIII. México: Fondo de Cultura Económica.

SLATER, D.R. (1997). Consumer culture and modernity. Cambridge: PolityPress. 



\title{
VESTIMENTA, MODA Y SOCIEDAD EN LA COMEDIA ESPAÑOLA DE BUENAS COSTUMBRES ${ }^{1}$
}

\author{
CLOTHING, FASHION AND SOCIETY IN SPANISH \\ NEOCLASSICAL COMEDY
}

\author{
JosÉ Roso DíAZ \\ Universidad de Extremadura \\ jrosodiaz@gmail.com
}

Recibido: $12 / 09 / 2016$

Aceptado: 12/12/2016

RESUMEN: En este trabajo analizamos el significado de la vestimenta, la forma de vestir y la moda en la comedia dieciochesca de buenas costumbres con la intención de aportar datos definitorios de la sociedad del momento. El teatro neoclásico fue buen escaparate de las mejoras sociales que pretendieron realizar los ilustrados y ello se observa en la forma de considerar la moda y los usos sociales del vestido. Se analizarán varias comedias donde se fija la importancia del recurso para los temas y la caracterización de personajes y se establece su valor como elemento para la crítica y la definición de tipos y grupos sociales.

PALABRAS CLAVE: Vestimenta, moda, sociedad, neoclasicismo, Comedia neoclásica española

ABSTRACT: This paper analyzes the significance of the dress, the dress and fashion in the eighteenth-century comedy of morals with the intention of providing data defining society at the time. The neoclassical theater was good showcase of social improvements that sought to make enlightened and this is seen in the way of looking at fashion and social customs of dress. Several comedies where the importance of the resource for themes and characterization of characters is fixed and its value is set as an element for critical and defining types and social groups will be analyzed.

KEYWORDS: Clothing, fashion, society, neoclassicism, Neoclassic Spanish comedy

En el teatro el vestuario es recurso que permite completar la caracterización de los personajes. Marca la apariencia externa del actor. Definido como "conjunto de trajes

\footnotetext{
${ }^{1}$ El presente trabajo se inscribe dentro del desarrollo del proyecto Familia y comunidad rural: mecanismos de protección comunitaria en el interior de la península ibérica [Fam\&Com] perteneciente al Programa estatal de Investigación, Desarrollo e Innovación orientada a los retos de la sociedad cuyo número de referencia es HAR2013-48901-c6-5-R.
} 
que se necesitan para la representación de una obra dramática"2 concreta una identidad social. Es, por tanto, elemento generador de información y significados diversos, significante de función múltiple que se integra en un sistema de sentido en el que tiene cabida también recursos de atrezzo como el maquillaje, el calzado o adornos (bigotes, pelucas, abanicos, joyas, etc.) y los gestos, el movimiento escénico, el lenguaje o la declamación, lo que evidencia que la identidad del personaje se construye en el teatro a partir de un proceso de superposición de signos. Su valor en las piezas, en todo caso, está determinado fundamentalmente por la complejidad o sencillez que presente, el color, la forma, el material, su expresión o simbolismo. Así el vestuario informa al espectador de hechos como la edad, el sexo, la psicología, la patria (nación o provincia), pertenencia a grupo, cambio de situación, enfermedad, clase o estamento social, situación civil, trabajo o profesión y grupo político o cultural, pero al mismo tiempo ofrece datos sobre el carácter y la construcción de la acción dramática, de distintas situaciones que en ella puedan darse y del ambiente general en que se desarrolla. Es decir lo que el traje habla y dice "no pertenece solo a la historia del teatro, sino que apunta a una mayor comprensión de los fenómenos sociales”, ya que "aparece atravesado por los elementos constitutivos de la cultura, la historia y el lenguaje".

No siempre, en todo caso, ha sido aprovechado en todas sus posibilidades el valor que el vestuario podía desempeñar en las tablas. De hecho hasta los siglos XVIII y XIX este recurso careció en realidad de la categoría de elemento teatral, ya que los actores no se vestían como el personaje al que iban a representar. No existía, por tanto, el principio de verosimilitud, la adecuación entre personaje o época y vestuario. Entonces las compañías vestían de la mejor manera posible a sus cómicos, algo que dependía sobre todo del papel que estos representasen en la pieza (primeros actores) y de la categoría y solvencia de aquellas. Me interesa destacar que la estética realista en el uso del vestuario teatral se inicia y progresa en Francia, en la época de la ilustración,

\footnotetext{
${ }^{2}$ A.M . PLATA TASENDE (2011). Diccionario de términos literarios. Madrid: Espasa. p. 761. Similar definición incluyen en sus diccionarios Estébanez Calderón, Gómez García o Pavis, insistiendo estos también en la importancia del paso a una estética más realista en la utilización del vestuario. Cf., D. ESTÉBANEZ CALDERÓN (1986). Diccionario de términos literarios. Madrid: Alianza Editorial; M. GÓMEZ GARCÍA (1997). Diccionario Akal de teatro. Madrid: Akal; P. PAVIS (1980). Diccionario del teatro: dramaturgia, estética y semiología. Barcelona: Paidós, 1980.

3 Cf. L. GUTMAN (2012). "Habitar el traje. Una reflexión sobre el vestuario teatral". Cuadernos de estudio en diseño y comunicación. Ensayos, 39, enero/marzo, pp. 178-179.
} 
de la mano de reformadores tan notables como Diderot y Voltaire y de cómicos famosos como Clairon o Garrick. En el caso de España las décadas finales del setecientos pusieron en muchos sentidos, aunque ciertamente con suerte dispar, dentro de un proceso general de reformas, la racionalización en las representaciones dramáticas con el deseo de mejorar de forma integral el estado del espectáculo. El teatro, considerado como arte útil, debía presentar a los personajes de forma creíble, con la propiedad necesaria, con el fin de contribuir de forma clara a la exposición de una enseñanza. Apreciado el valor semántico del vestuario se dio una reflexión sobre los errores, deficiencias y aciertos de su uso. Por diversos motivos, además, pronto adquirió relevancia un aspecto de grandes posibilidades dramáticas con él relacionado: la moda ${ }^{4}$.

Moda, que se define en el Diccionario de la Real Académica como "El uso, modo o costumbre que está en boga durante algún tiempo o en determinado país, con expectativa en los trajes, telas y adornos, especialmente los recién introducidos" es palabra procedente del término francés 'mode', que aparece ya recogida en el Diccionario de Autoridades como "uso, modo o costumbre. Tomase regularmente por el que es nuevamente introducido y con especialidad en los trages y modos de vestir". El significado viene marcado sobre todo por la búsqueda y necesidad de novedad. Esta idea de la moda se completa con claridad en el siglo XVIII cuando existen ya cambios notables en el modelo de sociedad, en la que aparecen las clases y cobran importancia aspectos como el consumo, el materialismo y el desarrollo de la imagen personal ${ }^{5}$. No

\footnotetext{
${ }^{4}$ Una bibliografía selecta y básica para iniciarse en el estudio de la moda es la siguiente: R. BARTHES (2008). El sistema de la moda y otros escritos. Barcelona: Paidós; N. SQUICCIANO (2012). El vestido habla. Consideraciones psicosociológicas sobre la indumentaria. Madrid: Cátedra; J. LAUER (2005). Breve historia del traje y la moda. Madrid: Cátedra; L. ALLISON (1994). El lenguaje de la moda. Barcelona: Paidós; G. LIPOVESTKY (1987). El imperio de lo efimero. La moda y su destino en las sociedades modernas. Madrid: Anagrama; F. BOUCHER (1967). Historia del traje en Occidente, desde la antigüedad hasta nuestros días. Barcelona: Montaner y Simón.

${ }^{5}$ Cf. A.M ${ }^{\mathrm{a}}$ DIAZ MARCOS (1981). La edad de seda: representaciones de la moda en la literatura española (1728-1926). Cádiz: Universidad de Cádiz; J.Ma SALA VALLDAURA (2003). "La mentalidad burguesa en las primeras comedias neoclásicas". En Soubeyroux, J. y Fernández Díaz, R. (Coord.). Historia social y literatura: familia y burguesía en España (siglos XVIII-XIX). Barcelona: Milenio, pp. 109-126; D. PÉREZ ABRIL (2007). "La influencia de la moda en la construcción de las identidades de género en las postrimerías del antiguo régimen". Revista de historia moderna, 33, pp. 313-322; A. DÍAZ MARCOS (2006). "Usías de bata y reloj: visiones de la moda en el siglo XVIII”. En Beltrán, R. (Ed.). Folklore, literatura e
} 
debe sorprendernos por ello que esta época genere en boca de filósofos, intelectuales y políticos una reflexión amplia sobre este fenómeno que ofrece hoy al estudioso numerosos datos culturales. La moda será, de hecho, el punto de encuentro de numerosos debates cuyo epicentro, como señala Dora Pérez, se situó en "las manifestaciones de la personalidad, carácter e identidad de género; los hábitos de consumo existentes y las formas del gasto, lujo y ostentación; la pertinencia del adorno; variaciones de hábitos en las formas y espacios de sociabilidad, como por

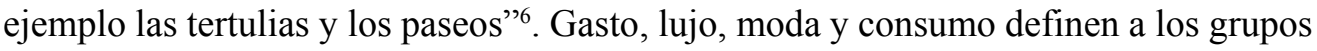
de poder de la sociedad que buscan tanto la distinción como la confirmación de su posición relevante 7 . En este escenario desempeña un papel destacado la burguesía, que imitará las formas de poder de las élites, para consolidar su hegemonía en la sociedad.

En la España de la época la preocupación por la moda se traduce en la adopción del estilo francés. Versalles, centro visible de la potencia más poderosa del mundo, marca la pauta y la recién inaugurada monarquía hispánica de los Borbones trae una forma de vestir caracterizada por la sofisticación, la riqueza, el lucimiento y el lujo. Así, en este ámbito se observa, por una parte, un interés desmedido por adoptar formas y estilos extranjeros ${ }^{8}$. Ese interés dio lugar a la configuración de estereotipos sociales,

indumentaria. La representación del vestido en la literatura y en la tradición oral. Madrid: Museo del Traje, pp. 38-52.

${ }^{6}$ D. PÉREZ ABRIL (2009). "Lujo, moda y modernidad en la prensa española del siglo XVIII". Res publica, 22, p. 250.

${ }^{7}$ De la cuestión se ha ocupado ya la historia social y la historia de la vida cotidiana. Resulta fundamental, para profundizar en ella, la siguiente bibliografía: M. GARCÍA FERNÁNDEZ (2012). "Consumo e identidad cultural urbana europea en el largo periodo de la transición hacia la modernidad". Revista de historiografia, 16, pp. 129-140; P. BOURDIEU (1988). La distinción. Criterios y bases sociales del gusto. Madrid: Taurus; M. GARCÍA FERNÁNDEZ (2011). "La cuestión de un traje nacional a finales del siglo XVIII. Demanda, consumo y gestión de la economía familiar". Norba. Revista de historia, 24, pp. 151-165; M. GARCÍA FERNÁNDEZ (2015). "Seguridades e inseguridades vestimentarias cotidianas entre la mayoría popular juvenil. Desde una civilización barroca y las nuevas Luces”. En Iglesias Rodríguez, J.J., Pérez García, R.M. y Fernández Chaves, M.F. (Coords.). Comercio y cultura en la edad moderna. Sevilla: Universidad de Sevilla, pp. 189-232; A. GIORGI (2015). "Apariencias de los varones jóvenes de las élites madrileñas durante el siglo XVIII". Revista de Demografía Histórica, XXXIII, I, pp. 43-63; M. GARCÍA FERNÁNDEZ (Coord.) (2013). Cultura material $y$ vida cotidiana moderna: escenarios. Madrid: Silex.

${ }^{8}$ Resulta fundamental, para el análisis del traje a finales del siglo XVIII la obra publicada en 1788 Discurso sobre el lujo de las señoras y un proyecto de traje nacional, que muestra ya la importancia del asunto en la época. Cf., además sobre la moda del vestido moderno, A. GIORGI (2008). "Ethos y Retórica, del Vestido a la Moda en el Madrid del siglo XVIII". Imafronte, 19- 
de ambos sexos y pertenecientes a las clases más elevadas, que se caracterizaban por adoptar formas internacionales en el vestir, donde sobresalía el amaneramiento, la frivolidad, la presencia de elementos extravagantes, la búsqueda de la exclusividad, la coquetería y la distinción social, que reflejaban modelos de conductas fácilmente criticables. A esta fórmula se ajustarían figuras como la del petimetre ${ }^{9}$, el gurrumino ${ }^{10}$, el currucato ${ }^{11}$, el lechugino ${ }^{12}$, el abate ${ }^{13}$, la madama ${ }^{14}$, el señorito ${ }^{15}$, el gomoso ${ }^{16} \mathrm{o}$ el

20, pp. 145-154. Para conocer la vestimenta masculina y femenina de la España de la época puede consultarse respectivamente J. PUIGGARI (1979). "Tiempos modernos. Sección $2^{\mathrm{a}}$. Rocoquismo. Siglo XVIII". Monografia del traje. México: Cosmos, pp. 228-250 y P. FERNÁNDEZ QUINTANILLA (1981). La mujer ilustrada en la España del siglo XVIII. Madrid: Ministerio de Cultura. Cf., sobre la mujer en el siglo XVIII, $\mathrm{M}^{\mathrm{a}} \mathrm{V}^{\mathrm{a}}$ LÓPEZ-CORDÓN CORTEZO (1986). "La situación de la mujer a finales del antiguo régimen (1760-1860). En Durán Heras, MªA y Capel Martínez, R.Ma (Coord.), Mujer y sociedad en España(1700-1975). Madrid: Ministerio de Trabajo e Inmigración, Instituto de la Mujer; $\mathrm{M}^{\mathrm{a}} \mathrm{V}^{\mathrm{a}}$ LÓPEZ-CORDÓN CORTEZO (2009). "La evolución de las damas entre los siglos XVII y XVIII". En Martínez Millán, J. y Marcal Lourenco, MaP. Las relaciones discretas entre las Monarquías Hispana y Portuguesa. Las casas de las Reinas (siglos XV-XIX). Madrid: Polifemo, 1357-1398; M.R. GARCÍA HURTADO (Coord.) (2016). El siglo XVIII en femenino. Madrid: Síntesis.

9 "El joven que cuida demasiadamente de su compostura, y de seguir las modas. Es voz compuesta de palabra francesa, e introducida sin necesidad" (Aut.). Cf., sobre este tipo, J. CAÑAS MURILLO y M.A. LAMA, (1994). "De petimetres y petimetras de la ilustración: $E l$ Petimetre por la mañana y El petimetre por la tarde, de Luis Álvarez Bracamonte". Anuario de Estudios Filológicos, XVII, pp. 27-55; J. CAÑAS MURILLO y M.A. LAMA (1997). "De petimetres y petimetras de la Ilustración: La petimetra por la mañana y La petimetra por la tarde, de Luis Álvarez Bracamonte”. Dieciocho, XX, 2, pp. 193-217.

10 "El marido que obedece indebidamente, y contempla con exceso a su muger. Es voz moderna" (Aut.).

11 "Muy afectado en el uso riguroso de las modas" (DRAE). El término no aparece en Aut..

12 "Persona joven que se compone mucho y sigue rigurosamente la moda", y también "Muchacho imberbe que se mete a galantear aparentando ser hombre" (DRAE). El término no aparece con tal acepción en Aut.

13 "Palabra italiana introducida modernamente para denotar al que anda vestido con cuello clerical, casaca y capa corta" (Aut.).

14 "Voz francesa y titulo de honor que vale lo mismo que Señora, y se da a las mugeres nobles puestas en estado, la qual se ha usado en España en el mismo sentido, para nombrar a las señoras extrangeras. Oy la utilizan algunos en el trato cortesano con las mugeres" (Aut).

15 "Se llama tambien el que afecta gravedad en sus acciones, o dominio y mando en lo que no le debe tener" (Aut).

16 "Hombre muy presumido que se preocupa excesivamente de su aspecto y de su arreglo personal" (DRAE). Con esta acepción no aparece en Aut. 
pisaverde ${ }^{17}$ que fueron ridiculizados en el teatro con la intención de poner en evidencia con gran nitidez determinados vicios y excesos sociales. Frente a la cursilería de lo nuevo y extranjero, por otra parte, como reacción lógica, con cierta originalidad, con buena acogida por parte de la aristocracia, surgió el fenómeno del majismo ${ }^{18}$, reacción casticista española que se nutría de los grupos sociales más populares y se definía sobre todo a partir de la aceptación y reivindicación de lo autóctono. Con él surgió la figura de los manolos, los majos, los chulapos y chisperos. Los debates sobre la moda, que tienen su traslado a las diversas artes, en fin, se producen en el siglo ilustrado a partir de un movimiento pendular que sitúa a la moral entre las coordinadas de modernidad y tradicionalismo. Ello se observa hasta la saciedad en los textos literarios de la centuria, en particular en la comedia de buenas costumbres neoclásica, donde el didactismo del tópico del enseñar deleitando expone la importancia que los ilustrados concedieron a la educación en la búsqueda de la mejora y modernización del país y la felicidad del pueblo.

En este trabajo queremos realizar precisamente un análisis del valor que tiene el vestuario en la construcción de personajes y en la elaboración de la acción de obras

17 “El mozuelo presumido de galán, holgazán, y sin empleo ni aplicación, que todo el dia se anda passeando. Covarrub. dice que es metaphora tomada del que atraviessa en algun jardin por los quadros, que por no pisar las labores va andando de puntillas, como hace regularmente el pisaverde" (Aut). Es sinónimo de gomoso. Cf., sobre estos términos y su presencia en obras neoclásicas, J.M. SALA VALLDAURA (2009). "Gurruminos, petimetres, abates y currucatos en el teatro breve del siglo XVIII”. Revista de Literatura, 71, No 142, pp. 429-460.

${ }^{18}$ Cf., J. CARO BAROJA (1980), "Los majos", en Temas castizos. Madrid, 1980, pp. 15-101.; A. GONZÁLEZ (1996). "La figura teatral del majo: conjetura y aproximaciones". En Sala Valldaura, J. M., El teatro español del siglo XVIII. Lleida, Vol. I, pp. 475-486; R. HAIDT (2011). "Los majos: el españolísimo gremio del teatro popular dieciochesco: sobre casticismo, inestabilidad y abyección”. Cuaderno de historia moderna, 10, pp. 155-173; R. DOMÍNGUEZ (2014). "Tipos populares en el Madrid del siglo XVIII: currucatos, majos, chisperos y damitas de nuevo cuño". Historia, pp. 70-74; M. GARCÍA FERNÁNDEZ (2009). "Entre paños y algodones: petimetres y castizas. ¿"la nueva moda en el arca se vende"?. En García Hurtado, M.R. (2009). La vida cotidiana en la España del siglo XVIII. Madrid: Silex; E. ALMEIDA (2013). "Vestir a la moda: cambios léxicos en la indumentaria hacia 1812: petimetres y majos". Hacia 1812 desde el siglo ilustrado. Actas del V Congreso Internacional de la Sociedad de Estudios del Siglo XVIII, pp. 309-320. Sobre el significado de los términos puede consultarse M. ALVAR ESQUERRA (2011). Diccionario de madrileñismos. Voces patrimoniales y populares en la Comunidad de Madrid. Madrid: La Librería; G. GIORGI (2012). "Vestir a la española y vestir a la francesa: apariencia y consumo en el Madrid del siglo XVIII". En Bartolomé Bartolomé, J.M. y García Fernández, M. (Eds.), Apariencias contrastadas: contraste de apariencias. León: Universidad de León, pp. 157-175. 
dramáticas pertenecientes al género literario histórico de la comedia neoclásica con el fin de ilustrar una de las formas en que los debates sobre la moda se desarrollan en el mundo de las letras. El estudio de la presencia, uso y función del traje se realiza a partir de la consideración de tres aspectos significativos: la incidencia del vestuario en la construcción de personajes, la visibilidad del traje y su utilización en las comedias y la relevancia de la moda en el desarrollo de los temas y la construcción de la acción de las piezas. El teatro, por lo demás, es un género que cumple a la perfección con el programa ilustrado de educar al pueblo en el bien común y las buenas costumbres.

Los ilustrados rompieron con la forma de concebir el teatro que tenían los dramaturgos barrocos y defendieron un teatro que, conforme a una nueva preceptiva, se ajustaba a las reglas clásicas, cumplía con las unidades dramáticas, se sujetaba a la verosimilitud y el decoro y contenía crítica social y didactismo para mejorar a la sociedad. Entre los nuevos géneros dramáticos, que lograron un éxito desigual debido sobre todo a que tuvieron en un principio que educar los gustos barrocos del público, destacan la tragedia y la comedia neoclásica, a la que la crítica denominó también comedia de buenas costumbres. Los comienzos de este género se sitúan según los estudiosos en el año 1762, cuando se publica La petimetra de Nicolás Fernández de Moratín ${ }^{19}$. Sin embargo pasaron algunos años más hasta que la primera obra de este tipo pudo representarse en un local comercial. La consolidación del género, por tanto, se produce tras un tortuoso proceso, que se cierra con obras como El señorito mimado (1787) y La señorita malcriada (1786) de Tomás de Iriarte. Alcanza su plenitud, en cualquier caso, con el éxito rotundo de El sí de las niñas (1801) de Leandro Fernández de Moratín y a partir de entonces la descomposición progresiva de su poética incidirá en la creación de otras formas teatrales, como la comedia realista, que triunfarán en las tablas a lo largo del siglo XIX ${ }^{20}$. La comedia neoclásica se caracterizará por tratar asuntos contemporáneos, su pretensión de moralizar con lecciones provechosas en las que el afán didáctico pone en valor la verdad y la virtud; la simplificación de la intriga,

${ }^{19}$ El hecho explica que una parte de la crítica denomine al género con el nombre de comedia moratiniana.

${ }^{20}$ Cf., para el estudio de este género, J. CAÑAS MURILLO (2000). Tipología de los personajes en la Comedia Española de Buenas Costumbres. Cáceres: Universidad de Extremadura (Trabajos del Departamento de Filología Hispánica); J. CHECA BELTRÁN (1998). Razones del buen gusto (Poética española del neoclasicismo). Madrid: CSIC; J. PÉREZ MAGALLÓN (2001). El teatro neoclásico. Madrid: Ediciones del Laberinto; A. CALDERONE. y F. DOMENECH (2003). "La comedia neoclásica". En Huerta Calvo, J. (Dir.). Historia del teatro español, II. Del siglo XVIII a la época actual. Madrid: Gredos, pp. 1603-1652. 
el ambiente urbano, la recurrencia a protagonistas pertenecientes a la clase burguesa, la existencia de crítica social moderada y la utilización de tipos sociales, que no evolucionan y quedan con gran detalle retratados en la acción. Hemos seleccionado para este estudio, entre las veinte comedias que según la crítica pertenecen con seguridad al género ${ }^{21}$, las obras que seguidamente se relacionan: La petimetra ${ }^{22}$ (1762), El señorito mimado ${ }^{23}$ (1787) y La familia a la moda ${ }^{24}$ (1804). Para la elaboración de este grupo se ha considerado la fecha de composición y el paratexto de las obras.

\section{EL VESTIR, LOS TRAJES Y LA MODA EN LA PETIMETRA DE NICOLÁS FERNÁNDEZ DE MORATÍN.}

La Petimetra es comedia muy significativa para el estudio de la moda en el teatro del siglo XVIII. El propio título de la pieza, que alude a uno de los personajes, ya lo advierte. Afecta tanto a la caracterización de los personajes como al desarrollo de los temas y la acción. Por ello la pieza contiene también un repertorio amplio de términos procedentes del campo semántico del vestuario, la moda y sus complementos.

En cuanto a la caracterización de los personajes cabe decir que contribuye a definir al agonista de doña Jerónima y, por contraste, al de su prima Maria. Es importante señalar que Moratín ofrece en la pieza dos modelos que se oponen: uno, el de la mujer ridícula afectada por la moda y preocupada exclusivamente por la apariencia; otro, el de la mujer que se ajusta a las normas del buen proceder y condena actitudes y comportamientos ridículos. La caracterización de Jerónima, la más interesante para nuestro análisis, se realiza a partir de tres procedimientos: por lo que el agonista dice,

${ }^{21}$ El corpus de comedias estaría formado por las siguientes obras, que se ofrecen organizadas en orden cronológico considerando en primer lugar fecha de composición $\mathrm{y}$, si existe duda, dato de estreno: La petimetra (1762), Hacer que hacemos (1770), Los menestrales (1784), El señorito mimado (1787), La señorita malcriada (1788), El don de gentes o la habanera (1790), El mal hombre, El viejo y la niña (estrenada en 1790; La comedia nueva (1790), El abuelo y la nieta (1796), La escuela de la amistad o el filósofo enamorado (1796), El sí de las niñas (1801), El barón (1799), La familia a la moda (1804), La mojigata (estrenada en 1804), El egoísta o el mal patriota (1813), Una noche de tertulia o el coronel don Raimundo (1828), Mi retrato y el de mi compadre (1829), Marcela, o ¿a cuál de los tres? (1831) y El pelo de la dehesa (1840). ${ }^{22}$ Cf., N. FERNÁNDEZ DE MORATÍN (1989). La Petimetra. Edición, introducción y notas de Jesús Cañas Murillo. Cáceres: Universidad de Extremadura.

${ }^{23}$ Cf., T. de IRIARTE (1986). El señorito mimado. La señorita malcriada. Edición de Russell P. Sebold. Madrid: Castalia.

${ }^{24}$ Cf., MaRa GÁlVEZ (1995). Safo. Zinda. La familia a la moda. Edición de Ferrando Domenech. Madrid: Asociación de Directores de Escena de España. 
por lo que el agonista hace y por lo que los demás personajes piensan y dicen del agonista, críticas a su comportamiento a partir de un doble proceso: el juicio propio y el juicio de terceros, que han sido antes caracterizados en la acción por el dramaturgo. Los tres procedimientos son convergentes y permiten ofrecer al espectador de forma bastante completa un tipo social ridículo, el del petimetre. En efecto, Jerónima es un personaje cerrado, que no presenta ninguna evolución, sino un comportamiento siempre socialmente sancionable. La técnica dramática del contraste se ve reforzada en las piezas con la aparición de una figura masculina, que responde al tipo, llamado Damián. Este se muestra enamorado de Jerónima y es figura opuesta de don Félix.

Jerónima queda definida sobre todo en la Jornada I y, luego, a lo largo de la acción, su caracterización se va consolidando por medio de recuerdos en la misma, que son más frecuentes en la Jornada III. Con ello el dramaturgo critica la ridiculez de un personaje repleto de defectos, que no evoluciona y muestra comportamientos poco apropiados para la mejora de la sociedad. Lo que para el agonista es signo de distinción, exclusividad y modernidad es tan solo en los demás reflejo de un defecto y vicio imperdonable. La incapacidad del personaje para percibir tal hecho marca su patetismo y el final de la pieza. Interesa a Moratín la denuncia de la preocupación excesiva por la apariencia y la moda, o el enorme gasto que conlleva el seguirla, y no el rechazo de las nuevas tendencias en el vestir que vienen de Francia.

Así Doña Jerónima se nos presenta como una mujer preocupada por ir a la moda: Jerónima: Mentecata, ¿te has criado en las Batuecas? ${ }^{25}$

Dime, ¿Dónde has visto tú que una mujer de mis prendas

use dos veces seguidas una cosa mesma?, que eso se estilará en tu lugar, donde todo el año entero, la propia saya y jubón, trae la mujer del alcalde,

\footnotetext{
${ }^{25}$ Nótese al utilizar el termino "Batuecas" el desprecio del personaje hacia aquellos otros que no van a la moda. En la época las Batuecas pasaban por ser lugar despoblado y apartado de la civilización.
} 
y, si no lo halla de balde, no se muda ni un cordón. mas yo que tal cual me veo, a Dios gracias, poderosa, ¿por qué he de usar una cosa como tú dices, arreo?

Martina: Es que el buen gusto pudiera ese defecto suplir

Jerónima: No hay gusto en el repetir ${ }^{26}$

El fragmento ofrece varios datos de interés. Por un lado la reivindicación del buen gusto en el vestir, que reside en la novedad, hecho poco acertado por el daño que puede acarrear a la economía familiar. Por otro el desprecio de la agonista de prendas propias del vestuario español de tiempos pasados: el jubón y saya. Apunta también el tema de la apariencia y de su importancia social.

La moda, en todo caso, afecta no solo al vestido, sino también al peinado, al calzado y a los complementos del traje. La preocupación por alfileres, espejos, abanicos, peines, sortijas, anillos, collares, ramilletes, arracadas, relojes, guantes, caja y frasquera o cintas es constante. Un ejemplo es el peinarse. Doña Jerónima es peinada por su criada, para ir a la última, despreocupándose del tiempo que dedica a ello, sin tener otra ocupación que realizar, incumpliendo si es necesario normas y comportamientos sociales relacionados con la espera o la puntualidad a la hora de acudir a un acto como la misa. Moratín pone en escena un aspecto de la vida privada de la mujer para marcar el carácter negativo y la enorme ridiculez de Jerónima, que se queja por los tirones de pelo que sufre para quedar perfecta:

\author{
¡Ay que mano tan pesada! \\ Válgame Dios, quién pudiera \\ ser cualquiera de vosotras, \\ que de mes a mes se peina \\ y con todo está decente. \\ Este trabajito lleva \\ la que tiene obligaciones
}

${ }^{26}$ Cf. ed. cit., pp. 90-91. 


$$
\text { como yo. }{ }^{27}
$$

Necesita, además, adornos que muestren su belleza a la última, por lo que desprecia todo instrumento de uso continuado o de tradición:

Damián: Estás, Jerónima bella, transformada en una Venus.

Jerónima: Las flores, ¿qué tal me sientan?

Damián: $\quad$ Mejor que no en tu jardín

Jerónima: ¿Y los polvos?

Damián Te hermosean.

Jerónima: ¿Cómo me dice el lunar?

Félix: $\quad$ Como al cielo las estrellas

Jerónima: Pues tráeme, Anita, abanicos

Ana: ¿Cuál queréis, el de la fiesta

de los toros de Aranjuez?

Jerónima: ¡Jesús, que cosa tan vieja!

Ana: ¿El del peneque?

Jerónima: Tampoco

Ana: ¿Del empedrado?

Jerónima

El que quieras,

como no sea una antigualla

Ana: $\quad$ El de la moda postrera

es este.

Jerónima: Muy bien; las cintas,

las sortijas, las pulseras,

los guantes, caja y frasquera,

El reloj, las arracadas,

Y lo que sabes que lleva

una mujer de mi porte ${ }^{28}$

El abanico es en la época complemento fundamental de toda dama que quiera ir a la moda. Jerónima, docta en el arte de vestirse a la última, empeña el día en tal asunto,

${ }^{27}$ Cf. ed. cit., p. 112.

${ }^{28}$ Cf. ed. cit., pp. 120-121. 
lo que implica su incompetencia en otros aspectos de la vida cotidiana (hacer un buen guiso o tareas domésticas como la limpieza, por ejemplo). Lo dice a su señor el criado Roque, con la sencillez y el humor que lo caracteriza. La burla desnuda al completo, hasta la risa del espectador, los defectos de tal mujer, muy similares a los de su pretendiente Damián, que es galán cortado por el mismo patrón. El hecho muestra que el vicio por la moda está en los dos sexos. La burla es por tanto doble:

$$
\begin{aligned}
& \text { Roque: } \\
& \text { yo en mi vida fui discreto, } \\
& \text { pero ahora me prometo } \\
& \text { un discurso superior. } \\
& \text { Esta madama fatal, } \\
& \text { exsahumanda con incienso, } \\
& \text { que la faltan, según pienso, } \\
& \text { ocho cuartos para un real, } \\
& \text { ¿posible es que te ha ligado } \\
& \text { con tal fuerza, señor mío, } \\
& \text { que te tenga el albedrio } \\
& \text { ciego y embarraganado? } \\
& \text { ¿No miras su presumpción, } \\
& \text { su melindre y su desdén, } \\
& \text { y aquel andan ten con ten } \\
& \text { cual paso de procesión? } \\
& \text { Pensando en el uso nuevo } \\
& \text { y en darse en la cara el unto, } \\
& \text { ni sabe coser un punto } \\
& \text { ni sabe echar sal a un huevo. }{ }^{29}
\end{aligned}
$$

$\mathrm{Al}$ asunto vuelve el criado poco después:

Si esta ha de ser tu mujer

¿sabes tú que sabe hacer?

${ }^{29}$ Cf. ed. cit., pp. 134-135. La cursiva es mía. 
isi es humilde y hacendosa?

Ahora bien, yo la pregunto,

digame esta niña, ¿cuál

se llama punto pascual,

cuál es de sábana el punto?

¿Cómo se pone un guisado?

¿Cómo se arrima una olla?

¿Cuántos cachos de cebolla

se echan en un estofado?

Vaya, que no sabe nada

de esto, ni ella lo ha estudiado,

sólo en hacer un guisado

juzgo que será extremada ${ }^{30}$

Tal característica se completa con la preocupación constante del agonista por ir a la moda y no parecer mal. Este fin justifica todo su comportamiento y actuar, incluidas la tardanza en acometer sus tareas o la preocupación obsesiva por el espejo. Es, en fin, un personaje preocupado por la forma de vestir siguiendo los dictados de la moda sin reparar en gastos $^{31}$.

El traje y la moda plantean en la comedia el tema de la apariencia y la preocupación por ir a la última o con buen gusto. En la pieza se denuncia el vicio de la apariencia, mostrando los defectos morales y los malos resultados que conlleva. El asunto presenta una dimensión muy extensa, en la que se incluye la moda, pero que contiene también el engaño (Jerónima engaña respecto a su dote) y las formas de mostrarse en sociedad. Sobre la moda el debate aborda el problema que conlleva sus excesos, no es considerada negativa en sí, sino cuando es en el individuo obsesión que le lleva a comportamientos poco provechosos. En el discurso de los sensatos, de los agonistas positivos, como Rodrigo o María, el rechazo y desprecio por esos excesos se dan en multitud de ocasiones, sin parlamentos extensos ni motivados, de forma muy efectiva, en menciones rápidas pero contundentes. Estos agonistas cumplen una función muy

\footnotetext{
${ }^{30}$ Cf. ed. cit., pp. 192-193.

${ }^{31}$ Se pueden traer varios ejemplos significativos presentes a lo largo de la pieza: Jerónima quiere ponerse manteletas y ponerse la primera cualquier moda que salga o ponerse excusali nuevo para lucir en la calle. Las gasto para la economía familiar, máximo cuando no se tiene dote, que conlleva la adquisición de estas piezas es enorme. Cf. ed. cit. p. 173 y 186.
} 
importante para el didactismo de la pieza, pues en sus intervenciones encontramos el pensamiento ilustrado que pretende trasmitir al público Moratín.

La preocupación por la vestimenta y la moda, en cualquier caso, afecta a otros temas, como es el caso del amor. Los personajes que se dejan llevar por las apariencias terminan fracasando, no saben amar o no tienen amor verdadero y son víctimas de sus falsos sentimientos, hecho que contribuye a marcar más lo ridículo de su comportamiento. Y ese fracaso refuerza la enseñanza ilustrada de la pieza.

La reflexión sobre la moda, en fin, hace que en la pieza estén presenten numerosas referencias a vestidos y términos pertenecientes a su campo semántico ${ }^{32}$, que enmarcan a veces la polémica entre el uso clásico español y la innovación francesa, muestran la preocupación por la moda en la época, reflejan la riqueza y variedad que presentan o sus usos sociales y apuntan vicios que deben ser corregidos y castigados en beneficio de las buenas costumbres que construyen una sociedad mejor

\section{EL VESTIR, LOS TRAJES Y LA MODA EN EL SEÑORITO MIMADO DE TOMÁS DE IRIARTE.}

En la comedia el asunto de la moda carece de valor, no aparece ni siquiera de forma secundaria. Tampoco hay alusiones a la indumentaria y sus adornos. Al respecto cabe decir solo que la preocupación por el vestirse es un rasgo más, sobre el que no se

\footnotetext{
${ }^{32}$ El léxico presente en la pieza referido al vestuario, los trajes y el mundo de la moda es el que seguidamente se relaciona: manto (79), basquiña 879), tocado (80), nedia (86), zapato (86), sombrero fino (86), espadín (86), capa de terciopelo (86), pitibú (90 y 155), cofieta (90), cinta del cigarrito (90), espejo (91, y después), peine (91, y después), guarniciones (94), falla (95), peinador (95), aspilleras (97), calandrajos (97), delantal (98), peinar en bolsa (98), peinar en moño (98), peinar en rodelas (98), telas (98), copete (98), bayeta (98) airón (107), alfiler (107), abanico (120), cintas $(94,121)$, sortijas (121), pulseras (121), collar $(121,152,173)$, reloj (121, 184), caja y frasquera (121), arracadas (121), alfileres (130), majo (131), madama (134), gorrona (135), frutera (138), calandrajo (138), entoldada (149), melindre (150), presumida (151), bata $(95,153,184)$, brial (153), pañuelo (154), manillas (154), rosario (154), graciosas hebillas (154), basquiñas (155), punta (155), vuelo (156), peto (173), lazos (173), excusalí (173), caja de tabaco (185), calzones (194), dominó (195), paletinas (185), cofietas (185), chinela (187), afeites ( para componerse, 188), falda (192), punto de manto (192), punto pascual (192), punto de sábana (192). Incluimos detrás de cada palabra el lugar de la comedia donde aparece. Este léxico explica por sí sólo la importancia que tiene en la comedia el asunto de la moda y el vestirse. La pieza, por otra parte es pobre en acotaciones de vestuario. En la actualidad trabajamos en la realización de un glosario de voces relacionadas con el vestuario, los trajes y el mundo de la moda en la comedia neoclásica española con el fin de conocer mejor su importancia tanto en la época como en la construcción de estas piezas.
} 
detiene la acción ni existen reflexiones de los agonistas, de Mariano, personaje que responde al tipo del petimetre. Lo advertimos en las indicaciones que se dan en acotaciones, en su forma de actuar, en la opinión que los demás tienen de él o en la forma que tiene de arruinar su casa por un gasto excesivo debido, entre otras cosas, a la visita a modistas. En palabras de Cristóbal, su tío y tutor sensato ${ }^{33}$ :

Cristóbal:

$$
[\cdots]
$$

Aqui verá usted prodigios

De esplendidez: francachelas

En casa de campo, en fondas;

Crédito abierto en las tiendas

De mercaderes, modistas;

Muchos tiros de colleras

Para fiestas de novillos;

Mucho asiento en la luneta

Por todo el año; un birlocho

Para lucir la destreza

Cocheril en los paseos;

Y otras partidas como éstas,

Que en breve tiempo darian

Con el mayorazgo en tierra.

Es decir, es en la pieza elemento que completa la caracterización del agonista ridículo, simple auxiliar sin ningún valor añadido o tratado. Cierto es que en determinadas ocasiones a lo largo de la comedia se ofrece una definición del agonista en la que entra en juego el asunto que nos ocupa: la vida disoluta y el exceso de gasto, la marcialidad, la mala educación, la inutilidad del petimetre o su rechazo a todo esfuerzo y trabajo. Varias acotaciones, en todo caso, nos ofrecen datos sobre la forma de vestir de Mariano ${ }^{34}$. Por lo demás la presencia del léxico sobre vestimenta, como

${ }^{33}$ Cf. ed. cit., p. 227.

${ }^{34}$ Ejemplo serían las siguientes: “(D. MARIANO llega vestido en traje de por la mañana, con un bastoncito de petimetre, etc. Sale por la puerta de la izquierda, dirigiéndose con alguna aceleración a entrar por la de en medio. Viene cantando entre dientes, y se suspende al ver a D. FAUSTO)" (183). Incluir el término 'petimetre' ya anuncia cómo va vestido el personaje (el autor lo expresa con un etc); “(D. MARIANO y D MÓNICA de basquiña y mantilla)” (261). 
consecuencia del escaso desarrollo que el recurso tiene en la pieza, es mínima ${ }^{35}$. En cambio otro elemento relacionado con la imagen del individuo y su proyección adquirirá mayor valor: el retrato.

\section{EL VESTIR, LOS TRAJES Y LA MODA EN LA FAMILIA A LA MODA DE Ma ROSA GÁLVEZ.}

En esta comedia vestidos y moda desempeñan una función importante tanto para la caracterización de los personajes como para la construcción de la acción y el desarrollo de temas. El sustantivo moda alude en la pieza al seguimiento del estilo francés en todos los ámbitos de la vida y no se limita exclusivamente a la indumentaria.

El vestuario permite caracterizar a los personajes, sobre todo a Madama de Pimpleas, que es una petimetra. Su criada se asemeja a ella, lo que permite la crítica fácil de la preocupación por el vestir a partir del humor propio del mundo de los criados. Así en el Acto I Teresa afirma tener un resfriado, hecho explicable en opinión de Pablo por llevar traje al estilo francés, que es ir casi como desnuda ${ }^{36}$ :

Pablo: A ti te causa ese mal

el traje de sutileza.

Desde que en Francia estuviste

con el ama, has adquirido

un desnudo en el vestido

que te trasluces

Madama de Pimpleas representa el nuevo estilo procedente de Francia que triunfa en la Corte y en la ciudad. Frente a él se sitúa doña Guiomar, que sigue la antigua usanza española existente en el mundo rural de las montañas donde vive. Aparece, por tanto, en la pieza el conflicto entre dos formas de vestir que se dieron en la época, pero vinculando una al gasto excesivo y a comportamientos ridículos y afectados y otra a la sensatez y prudencia que debe seguir toda buena casa ${ }^{37}$. Esta oposición se da incluso en otros aspectos como el peinado o la decoración y da valor al recurso del contraste.

\footnotetext{
${ }^{35} \mathrm{Al}$ respecto solo se registran en la pieza los siguientes términos: traje de caballero (209), capote jerezano (con valor peyorativo) (209). Estos dos términos oponen modelos sociales, una prestigiado y el otro carente del menor reconocimiento y criticado; vestido negro (traje típico del oficio de notario o justicia) (253), basquiña (261), mantilla (261), golilla (gorra de criados), (292) y bastoncito (183).

${ }^{36}$ Cf., ed. cit., pp. 142-143

${ }^{37}$ Cf., ed. cit., p. 147.
} 
Doña Guiomar, por ejemplo, rechaza la cama en la que durmió, aunque es estilo último ${ }^{38}$ :

Guiomar:No. La cama que me has dado

es un potro de tormento.

En ella el cuerpo se encierra

lo mismo que en un cajón,

y a más, por su ondulación,

parece hay temblor de tierra.

Tengo unos banquillos feos

por sillas, que son iguales

a los que en los tribunales

se permiten a los reos.

De modo que si tuviera

alguien que me visitara

decirle que se sentara

hora decir que se fuera.

Pero de lo que me espanto

es de que, siendo cristiana,

no le hayas puesto a tu hermana

en su alcoba ningún santo

El enfrentamiento de estilos aparece en la pieza en varias ocasiones. En una de ellas Madama Pimpleas critica lo mal vestida que va Guiomar ${ }^{39}$ :

Madama: jJesús, qué poco elegante

estás, y qué mal vestida!

Guimar: Mujer, pues allá en Laredo

por muy petimetra paso

Canuto: Eso ahora no es del caso, sino obsequiarla

Madama: No puedo hacerla obsequio mayor

\footnotetext{
${ }^{38}$ Cf., ed. cit., p. 160.
}

${ }^{39}$ Cf. ed. cit., p. 172. 
que cuidar de su decencia

Ir a la moda significa lugar social, algo que preocupa a todos los que valoran las apariencias. El personaje se define por el vestido. En opinión de Madama la moda permite introducir en la alta sociedad a la familia de Canuto ${ }^{40}$ :

\section{Madama: $\quad[\ldots]$ \\ El publicó la elegancia [se refiere al Marqués] \\ de mis trajes y mis modas \\ que antes despreciaban todas \\ aunque había estado en Francia. \\ Condujo a verme mil gentes \\ de la bella sociedad \\ y me dio celebridad \\ en tertulias diferentes}

La búsqueda de la elegancia y el vestido nuevo favorece la incorporación en la acción del fenómeno social del cortejo y la figura del chischiveo. Se trata, como señala Noelia Gómez, de la posibilidad, importada de Europa, de que "una mujer casada tuviera un acompañante cuando su esposo estuviera atendiendo sus negocios o los actos sociales a los que acudía solo. Este acompañante en ausencia del marido era un hombre enamorado de la dama que asumí, en cuanto que cortejo, ciertos deberes para con ella, como el de asistirla en su arreglo personal, regalarla objetos de moda primorosos, asesorarla en cuestión de modas, acompañarla a eventos, actos sociales y paseos, ..." 41 Tener cortejo era reflejo de posición social elevado y pasaba por buen adorno de la dama. El chischiveo alude al galán que servía platónicamente a una dama de la alta sociedad. Ocurre entre el Marqués de Altopunto y Madama de Pimpleas. Así el Marqués visita en su tocador, estancia privada, a madama, mujer de Canuto, para ayudarle a vestirse, lo que muestra una de las formas del cortejo dieciochesco ${ }^{42}$ :

Marqués: Adiós, voy al tocador,

${ }^{40}$ Cf., ed. cit., p. 200.

${ }^{41}$ Cf. N. GÓMEZ JARQUE. "El cortejo y las figuras del petimetre y el majo en algunos textos literarios y obras pictóricas del siglo XVIII". Espéculo. Revista de estudios literarios (UCM), 37, en http://www.ucm.es/info/especulo/numero37/petimetr.html [consulta 10 de mayo de 2016].

${ }^{42}$ Cf., ed. cit., p. 167. El hecho se repetirá más tarde en términos similares cuando el Marqués ayuda a vestir a la madama el descuido (179). 
para ayudar a vestir

a tu esposa.

Canuto:Hazla salir

pronto

La indumentaria adquiere un especial valor en el Acto I, donde se ofrece la caracterización de los personajes que favorece el planteamiento de los temas. Incide, en cualquier caso, en el desarrollo de un tema importante en la pieza, la crítica al gasto continuado y excesivo, motivo de la ruina de una casa. Lo vemos como discurso ilustrado representado en los tres actos de la pieza. En el primero Guiomar afirma que su cuñada gasta mucho en moda. La petimetría arruinará su casa confirma el juicioso Facundo ${ }^{43}$ :

Facundo: Señora,

harto habéis dicho con esto.

Porque vierais tal exceso

os llamé. Escuchadme ahora.

Yo, por amor de mi hijo,

presté mucho a vuestro hermano

para sostenerlo en vano

$y$ de esto sólo me aflijo.

Las modas de su mujer

y el juego que lo domina

van a causar su ruina,

que tanto llego a temer.

La necesidad de dinero, el gasto incontrolado, lleva a empeñar objetos de la casa. Así Faustino comprometerá un reloj para pagar una de sus muchas deudas. Ir a la moda es acabar en la ruina ${ }^{44}$. Trapachino, por ejemplo, pide a Guiomar dinero para pagar a una modista la deuda de Madama ${ }^{45}$. Poner el asunto en boca de diversos personajes significa desarrollarlo desde una perspectiva múltiple y sostenida en el desarrollo de la acción.

\footnotetext{
${ }^{43}$ Cf., ed. cit., p. 155. Más tarde el mismo Facundo afirmará que la ruina de Canuto es debida al seguimiento de la moda francesa, que supone derrochar y gastar mucho y lograr elegancia (155).

${ }^{44}$ Cf., ed. cit., p. 224 y 231.

${ }^{45}$ Cf., ed. cit., pp. 210-211.
} 
Abunda en la obra el léxico de términos pertenecientes a la indumentaria y sus adornos $^{46}$. Apreciamos la presencia de términos antiguos, que representan al estilo viejo, junto a otros nuevos, claros galicismos, que marcan los nuevos tiempos. Junto a esta circunstancia debemos señalar la existencia de numerosas acotaciones de vestuario, sobre todo en el Acto I, que ofrecen una primera información del personaje.

\section{FINAL: MODA, TEATRO Y SOCIEDAD.}

Apreciamos en el análisis de las piezas que los vestidos y sus usos sociales están presentes de forma constante, aunque con significado y valor desigual, en el género histórico de la comedia neoclásica. Fue, por tanto, un elemento siempre considerado por los dramaturgos ilustrados a la hora de componer sus obras. El recurso afecta de forma directa a la caracterización de personajes, con frecuencia tipos, que pueden representar vicios o virtudes sociales. Por él quedan definidos agonistas de ambos sexos, principales y secundarios, positivos y negativos, lo que viene a indicar la actualidad del debate sobre la indumentaria en la sociedad de la época. Potencia, además, la ridiculización del tipo del petimetre, preocupado hasta la obsesión por un aspecto exterior cuidado y refinado con notable presencia de elementos extravagantes.

El recurso favorece, además, la aparición en las tablas de nuevos temas como la ruina de la hacienda por el gasto incontrolado, la mala educación, la reivindicación del trabajo, el valor de la apariencia, el buen gusto o el seguimiento de las modas, todos ellos esenciales en el programa ilustrado de reforma y mejora del pueblo. Para ello se acude a la ironía, la burla, el humor o la ridiculización de defectos, elementos que contribuyen a potenciar el didactismo.

La recurrencia a la vestimenta, en cualquier caso, revela formas de la relación social, el valor del espacio público y privado o la creación de una imagen o identidad personal. El chischiveo, el cortejo, la búsqueda de la elegancia, el adorno, la moda o las funciones del tocador así nos lo confirma. Plantea también un debate entre el estilo antiguo, propiamente español, y el nuevo que viene de Francia, hecho que no es

\footnotetext{
${ }^{46}$ En la pieza aparece el siguiente léxico: camisa (141), traje de sutileza (142), desnudo en el vestido (143), petimetrías (144), madama (145 y ss), pantalón (147), chaqueta (147), toileta (148. Nótese el galicismo), tocador (148), elegancia (la ropa moderna da elegancia, 155, 175), bata (159), copete (peinado, 162), vestido ricamente en cuerpo (166), espada (166), tocado (167), petimetra (172 y ss), alhajas (172), diamantes (172), sombrero (176), traje de librea (178. Es traje de criados), descuido (189), vestido de gala $(181,203)$, tocador (195), rosa (adorno, 203), y reloj (212).
} 
gratuito en las piezas ya que describe en buena medida el enfrentamiento de dos grupos sociales existentes en el país: por un lado los tradicionalistas y, por otro, los partidarios de novedades. Estas posturas identifican grupos sociales diferenciados, la burguesía emergente y la nobleza, que pretende seguir anclada en sus privilegios. Conviene señalar, en todo caso, que el discurso que ofrecen estas comedias no es contra la moda, sino contra los excesos que cometen aquellos que la siguen ciegamente sin reparar en gastos y en el peligro que tal hecho supone para sus haciendas. Todo ello otorga un realismo a las piezas que adelanta ya sin duda formas dramáticas decimonónicas.

El significado de la presencia, uso y función de la vestimenta se logra, por lo demás, a partir de elementos y recursos que pertenecen a la poética del género histórico de la comedia neoclásica, donde cumple una función destacada la técnica del contraste, la utilización de tipos, la perspectiva múltiple, el didactismo o la ironía. La acotación de vestuario cobra importancia a veces en la caracterización de personajes, ofrecen de los mismos el primer dato. La importancia del mundo de la moda se observa sin duda en la abundante presencia de términos pertenecientes al campo semántico del vestido y sus adornos o complementos. Este léxico manifiesta una fuerte influencia francesa (galicismos), la polémica entre estilos, la rapidez de los cambios en el vestir, el significado y la simbología de sus adornos, el valor social de la ropa o la diferenciación de grupos. Se puede afirmar que estos dramaturgos estaban al tanto de lo que ocurría en la sociedad española con el traje y la moda. Pero no solo eso, supieron ver también su valor dentro del modelo dramático que defendían para educar al pueblo en las buenas costumbres. 

Sección II: ESTUDIOS 



\title{
LA RESPUESTA PATRONAL DURANTE LA RESTAURACIÓN ANTE LOS ACCIDENTES LABORALES EN UNA EMPRESA MINERA. EL CASO DE LA SOCIEDAD ANÓNIMA MINAS DE RIOSA (ASTURIAS, 1899-1916).
}

\author{
RESPONSE OF THE ENTREPRENEURS IN A MINING \\ ACCIDENT DURING THE RESTORATION. THE CASE OF \\ SOCIEDAD ANÓNIMA MINAS DE RIOSA (ASTURIAS, 1899-1916).
}

\author{
MERCEDES FERNÁNDEZ MENÉNDEZ \\ Administración del Principado de Asturias \\ mercelacaleya@yahoo.es
}

Recibido: $18 / 12 / 2015$

Aceptado: 28/04/2016

RESUMEN: A mediados del siglo XIX se comenzó a desarrollar la legislación laboral en España, pero su hito principal vendría dado por la Ley de Accidentes del Trabajo del año 1900. Ésta reconocía la responsabilidad del empresario sobre los daños que sufrieran sus obreros en los siniestros acaecidos durante su jornada laboral. Estudiamos la respuesta patronal ante los accidentes mineros cuando dicha norma entra en vigor, centrándonos en el caso de la Sociedad Anónima Minas de Riosa, mediante el estudio de cuatro expedientes de accidentes de especial importancia que se conservan en su archivo empresarial.

PALABRAS CLAVE: Minería, explotación hullera, accidentes laborales, legislación laboral, Riosa, Asturias.

ABSTRACT: A mid-nineteenth century began to develop labor legislation in Spain, but the main milestone was a law from 1900, relationship with de labor accidents. This recognized the responsibility of the employer about the damage his workers suffered accidents that occur in during working hours. We study the employer's answer about the mining accidents when the law started. We will know about the Sociedad Anónima Minas de Riosa by studying the records of accidents that are preserved in their business file.

KEYWORDS: Mining, coal mining, work accidents, labor legislation, Riosa, Asturias. 


\section{LA SOCIEDAD ANÓNIMA MINAS DE RIOSA}

El rico yacimiento carbonífero de los concejos de Morcín y Riosa (Asturias) comenzó a ser explotado en 1846 por la Fábrica Nacional de Cañones de Trubia, la cual, debido al alto poder de coquizacion del mineral, lo destinaba a alimentar sus altos hornos ${ }^{1}$. Décadas más tarde, el Estado decidió que no le convenía su explotación directa y procedió a la subasta pública del coto hullero, que fue comprado en 1899 por la Sociedad Anónima Minas de Riosa. Ésta había sido constituida el 19 de abril de ese año, con el único fin de hacerse con el citado yacimiento 2 . Sus ocho socios fundadores (Fernando Merino, Manuel Uría, Inocencio Fernández Martínez, Gregorio VigilEscalera Crespo, Juan González Posada, Alfredo Santos Arana, Miguel González Posada y Vicente Fernández Herrero) aportaron 2.000.000 de pesetas, cantidad nada desdeñable, y constituían una representación de la clase alta durante la Restauración ${ }^{3}$. Esta compañía va a emplear los más modernos adelantos técnicos del momento aplicados a la extracción de la hulla con el fin de convertir estas minas en el más destacado filón de mineral carbonífero del país. A decir de María Fernanda Fernández, en este yacimiento se da uno de los primeros ejemplos de explotación del Principado, pionero en su organización a gran escala y moderno en su planteamiento estratégico ${ }^{4}$.

Las ambiciosas pretensiones de los accionistas pronto se vieron desbaratadas por una realidad que se escapaba a sus planes iniciales. En 1900 habían comenzado a construirse en La Pereda (Mieres) los cargaderos y otras instalaciones necesarias para el tratamiento del carbón en bruto, como el lavadero y sus balsas de decantación, que comienza a operar en 1903. A pesar de tal brío inicial, las fortísimas inyecciones de capital que eran necesarias, la presión tributaria del Estado y las dificultades para la comercialización del producto, a causa de la falta de vías férreas de carácter nacional,

\footnotetext{
${ }^{1}$ RADA Y DELGADO, J. (1858). Viaje de SS.MM. y AA por Castilla, León, Asturias y Galicia verificado en el verano de 1858 [en línea]. [Consulta 7/05/2013]. Disponible en: http://babel.hathitrust.org/cgi/pt?id=nyp.33433004962811;view=1up;seq=9, p. 410.

2 FERNÁNDEZ MENÉNDEZ, M. (2015). La Sociedad Anónima Minas de Riosa en la industrialización asturiana (1899 - 1916). Estudio del fondo documental de su archivo empresarial. Tesis doctoral. Directores $\mathrm{M}^{\mathrm{a}}$ del Carmen Rodríguez y Jorge Muñiz. Universidad de León. Departamento de Patrimonio Artístico y Documental.

${ }^{3}$ Registro Mercantil y de Bienes Muebles de Asturias, Sección 1, hoja 255, folio 171, anotación $1^{\mathrm{a}}$.

${ }^{4}$ FERNÁNDEZ GUTIÉRREZ, M. F. (2005). "Minas de Riosa, Asturias: un persistente éxito empresarial (siglos XIX y XX)". En VIII Congreso de la Asociación Española de Historia Económica (Galicia, septiembre 2005), p. 4. [en línea]. [Consulta 12/11/2012]. Disponible en: http://www.usc.es/estaticos/congresos/histec05/b16 fernandez_gutierrez.pdf.
} 
hicieron que, en una junta general extraordinaria celebrada el 15 de marzo de 1905, se declarase en liquidación la compañía y así, el día 28 de julio de ese año ${ }^{5}$, transfirieron sus propiedades a Hulleras de Ujo-Mieres ${ }^{6}$ a cambio de 173.000 acciones de 25 pesetas, como parte de un proceso de liquidación largo y complejo, del que se encargó, casi en solitario, Inocencio Fernández Martínez. Dicha situación se prolongó hasta agosto de 1916, debido a diversas obligaciones y problemas contractuales de la empresa. A pesar de que la existencia de esta compañía se circunscribe a tan sólo diecisiete años -entre 1899 y 1916-alberga gran interés para comprender la historia empresarial y social de Asturias gracias a la conservación prácticamente total de su $\operatorname{archivo}^{7}$. La cuestión que aquí nos ocupa es ver la actitud de la Sociedad Anónima Minas de Riosa ante la nueva legislación laboral, que, necesariamente, habría de repercutir en sus relaciones laborales internas y, también, en su maltrecha economía.

\section{LOS COMIENZOS DE LA ASISTENCIA SOCIAL Y LA PREVENCÍÓN DE LOS RIESGOS LABORALES EN NUESTRO PAIIS}

El desarrollo de actividad por parte de la Sociedad Anónima Minas de Riosa tiene lugar en un periodo muy significativo en lo que a conformación del Derecho del Trabajo en España se refiere, que permite acercarse a una época fascinante coincidente con la consolidación de los primeros focos de producción fabril y con la formación del mercado nacional, que se caracteriza por la aparición de una serie de problemas sociales y políticos derivados de las condiciones de vida y trabajo de los obreros asalariados $^{8}$. El paso de legislación del trabajo, entendiendo ésta como aisladas normas especiales de regulación de las relaciones de trabajo, a Derecho del Trabajo, como un conjunto normativo dotado de una cierta sistematización, no se produce en Europa hasta los años siguientes a la Primera Guerra Mundial ${ }^{9}$.

\footnotetext{
${ }^{5}$ Registro Mercantil y de Bienes Muebles de Asturias, Sección 1, hoja 255, folio 174, anotación $5^{\mathrm{a}}$.

${ }^{6}$ La Compañía de las Hulleras de Ujo-Mieres se había constituido en Ujo, el 1 de abril de 1905, para la explotación de minas de carbón con un capital de ochenta mil acciones de cincuenta pesetas y la mayor parte del accionariado era originariamente francés. Su primer consejo de administración lo compusieron Felix Chalchat, Henri de Loune y Solliers, Xavier Lauras y Coste, Henri Marrete y Piriatelli, Jules Clavier, y Antoine Peraldi.

${ }^{7}$ Fondo Minas de Riosa. Se conserva en el Archivo del Real Instituto de Estudios Asturianos. Sede Web institucional: http://ridea.org/

${ }^{8}$ ARTOLA, M. Antiguo Régimen y revolución liberal, Barcelona: Ariel, 1978, p. 157 y ss.

9 MARTÍN VALVERDE, A., RODRÍGUEZ-SAÑUDO GUTIÉRREZ, F. y GARCÍA MURCIA, J. (1991). Derecho del Trabajo. Madrid: Tecnos, p. 61. Así, la materia que antes se
} 
Dos son los conceptos claves para comprender el origen y desarrollo de la reglamentación laboral en nuestro país: cuestión social y reforma social. Tradicionalmente se señala el primero como el nombre con el que ha pasado a la historia el conjunto de problemas políticos y sociales generados en la primera fase del liberalismo y la industrialización. Estas cuestiones generarán el segundo de los conceptos señalados. Así pues, la reforma social se refiere a los cambios ideológicos y las subsiguientes respuestas legislativas que, a resultas de la cuestión social, se suscitan en España ${ }^{10}$. Llegó un momento en el que se hizo precisa cierta mediación gubernativa, que interviniese y arbitrase soluciones que se alejasen de los principios del liberalismo con los que se había pretendido abordar la situación. Se trataba de paliar el malestar que generaba la efectiva situación de explotación de la mano de obra industrial. Esta coyuntura debe ser subrayada, ya que la empresa objeto de estudio se encuentra en un momento histórico único, caldo de cultivo que iniciará un cambio, como nunca lo había habido antes en la historia, en la regulación y conceptualización de la explotación de la fuerza de trabajo ${ }^{11}$.

La llamada Ley Benot, de 1873, puede considerarse la precursora de la legislación laboral en nuestro país. Ésta prohibía que los menores de diez años desarrollasen

abordaba con una o dos leyes, actualmente es un terreno salpicado por un complejo de cuerpos normativos de lo más variopinto y prolijo. Hoy en día, y en lo que toca a la específica materia de seguridad minera, nos encontramos con una serie de normativas, mientras que en el periodo estudiado con una única ley, dos a lo sumo, se regulaba el ámbito de actuación, por no hablar de las cuestiones que tocan la legislación sobre prevención de riesgos laborales. Véase la sede Web del Ministerio de Industria, Energía y Turismo, donde podemos encontrar recogida y ordenada la legislación vigente sobre seguridad minera: http://www.minetur.gob.es/esES/Paginas/index.aspx-

${ }^{10}$ Así lo propugnó Bartolomé Clavero en su obra Institución de la reforma social y constitución del Derecho del Trabajo, de la que han bebido la mayor parte de los historiadores, sociólogos y juristas que han trabajado en cuestiones de derecho del trabajo en nuestro país: CLAVERO SALVADOR, B. (1989). "Institución de la reforma social y constitución del Derecho del Trabajo". Anuario de Historia del Derecho Español, LIX, pp. 859-884.

${ }^{11}$ Alfredo Montoya señala que el derecho del trabajo aparece tras la generalización de un tipo específico de trabajo, el trabajo voluntario, dependiente y por cuenta ajena, que desplaza definitivamente las relaciones laborales forzosas. Según el autor ese será el paso previo a que se sienta la necesidad de dotar de una nueva ordenación jurídica al trabajo humano. MONTOYA MELGAR, A. (2008). Derecho del trabajo. Madrid: Tecnos, p. 62. 
ciertos trabajos ${ }^{12}$. En el ámbito que nos ocupa, la minería, la preocupación normativa por la seguridad y salud en tan peligrosas explotaciones no encuentra una primera concreción (...) hasta el Decreto de 29 de diciembre de 1868, por el que se aprueban las bases de la Ley de Minas, y cuyo art. 29 contemplaba, de futuro, "un reglamento de policía que fijará (...) muy principalmente los preceptos de salubridad pública a que estarán sujetas las minas ${ }^{13}$. El citado reglamento no llegó hasta $1897^{14}$ (reformado posteriormente en 1904). Mayor trascendencia tuvo la creación, por el Ministerio de la Gobernación, en 1883, de la Comisión de Reformas Sociales ${ }^{15}$, que desembocó en 1903 en la instauración del Instituto de Reformas Sociales ${ }^{16}$. El preámbulo del Real Decreto de 1883 argumentaba que numerosos sintomas revelan que las clases obreras sienten el vivo estímulo de necesidades que importa redimir, o aliviar cuando menos, a la vez que siente el capital inquietudes justificadas por hondas y continuas perturbaciones. La sentencia muestra como, tras la pátina de preocupación social, asoma el interés último por tranquilizar al capital.

En el año 1900 se produce un paso más en el necesario intervencionismo del Estado frente al abstencionismo. Fue en estos momentos cuando se promulgó la Ley de Accidentes del Trabajo, también llamada Ley Dato. Constituyó todo un hito, pues se venía a establecer una cierta justicia social muy necesaria, frente a la situación precedente. Tres fueron los problemas básicos de los que se preocupó esta legislación: la protección de mujeres y menores, la prevención y cobertura de accidentes laborales

12 ESPAÑA. Ley excluyendo á los niños y niñas menores de 10 años del trabajo en fábricas, talleres, fundiciones ó minas, y fijando las horas de trabajo en las mismas. Gaceta de Madrid núm. 209, de 28 de Julio de 1873, p. 1193.

${ }^{13}$ FERNÁNDEZ SAN ELÍAS, F. (2011). La prevención de riesgos laborales en el sector de la minería del carbón. Universidad de León. Departamento del derecho privado y de la empresa. Director, Juan José Fernández Domínguez, p. 26 y ss. [en línea]. [Consulta 1/05/2014]. Disponible en: https://buleria.unileon.es/bitstream/handle/10612/819/2010FERN\%C3\%81NDEZ\%20SAN\% 20EL\%C3\%8DAS, \%20FERNANDO.pdf?sequence $=1$

${ }^{14}$ ESPAÑA. Real decreto aprobando el reglamento de Policía minera. Gaceta de Madrid núm. 199, de 18 de Julio de 1897, pp. 229-230.

15 ESPAÑA. Real decreto creando una comisión para el estudio de las cuestiones que directamente interesen al bienestar de las clases obreras y que afecten á las relaciones entre el capital y el trabajo, de 5 de diciembre de 1883, Gaceta de Madrid, núm. 344, 10 de diciembre de 1883.

${ }^{16}$ ESPAÑA. Real decreto de 23 de abril de 1903 por el que se crea el Instituto de Reformas Sociales. Gaceta de Madrid, núm. 120, 30 de Abril de 1903. 
y las disposiciones sobre descanso dominical y jornada máxima de trabajo ${ }^{17}$. A decir de Jeronia Pons, el cambio institucional que se inauguró en España con la aprobación en 1900 de la primera ley de accidentes de trabajo, provocó una serie de transformaciones que afectaron a las relaciones laborales y al desarrollo de la previsión social ${ }^{18}$. Conllevó igualmente un trabajo de investigación e información sobre los problemas sociales de las clases trabajadoras ${ }^{19}$ sin precedentes promovido por los poderes públicos y llamó a las cosas por su nombre; señaló que el contrato de trabajo no ponía frente a frente a dos partes iguales, como pretendía el liberalismo, sino a un empresario y a un obrero, con grandes diferencias de poder entre ambos ${ }^{20}$. Esta Ley es revolucionaria frente a la regulación que se le daba anteriormente a la cuestión, abordada por el Código Civil. A partir de ese momento el empresario no podría inhibirse de su responsabilidad frente al accidente del obrero; de hecho, en el artículo diecisiete, se establecía que los daños y perjuicios, ocasionados con dolo, imprudencia ó negligencia, que constituyesen delito ó falta con arreglo al Código Penal, responderían en un juicio correspondiente a los jueces y tribunales de lo criminal.

Aunque nació con la intención de ocuparse tanto de la seguridad e higiene en el trabajo, como de la responsabilidad del empresario por las lesiones producidas por accidente durante el desarrollo del mismo, la norma sólo aborda abiertamente lo

\footnotetext{
${ }^{17}$ Estaba dividida en siete capítulos: (Disposiciones generales, De las obligaciones, De las reclamaciones, De las intervenciones, Previsión de los accidentes del trabajo, De las responsabilidades, Seguro de accidentes), con un total de setenta y dos artículos y un artículo transitorio. ESPAÑA. Ley relativa a prevenir los accidentes del trabajo, y forma de indemnizar á los obreros que sean víctimas de dichos accidentes. Gaceta de Madrid núm. 31, de 31 de enero de 1900, p. 363-364.

${ }^{18}$ PONS PONS, J. (2006). El seguro de accidentes de trabajo en España: de la obligación al negocio (1900-1940). Investigaciones de historia económica. núm. 4. p. 78. En línea, disponible en: http://www.aehe.net/publicaciones/ihe/archivos/ihe4/AR_03_Pons_Jeronia_N4_Pp77100.pdf

19 MARTÍN VALVERDE, A., RODRÍGUEZ-SAÑUDO GUTIÉRREZ, F. y GARCÍA MURCIA, J., Op. Cit. p. 68.

${ }^{20}$ MONTOYA MELGAR, A. Op. Cit. p. 65. Sobre este particular también insisten otros autores como Juan M. Ramírez, cuando apunta que la libertad fue exclusivamente de la parte económicamente más fuerte que pudo imponer a su antojo las condiciones contractuales a la contraparte, limitándose la libertad material de esta última a aceptarlas o a engrosar las filas de desempleados. RAMÍREZ MARTÍNEZ, J.M. (2010). Curso de derecho del trabajo. Valencia: Tirant le Blanc, p. 31.
} 
segundo y dejaba fuera de su respaldo a algunos ámbitos como la agricultura. Por otra parte, consagra los conceptos clásicos de accidente, sin alusión a la enfermedad profesiona $^{21}$ y no establecía la obligatoriedad para los patronos de suscribir un seguro de accidentes para sus trabajadores, sino que esta opción quedaba al libre albedrío del empresario. Ester Martínez señaló que se trataba de revestir de legalidad la situación creada a partir de una desgracia o negligencia. Para esta autora, en realidad, lo que la ley permite, sin imponerlo, es el seguro del patrono, no el del obrero, aunque a la postre el primero beneficie al segundo, amparándolo del riesgo de la insolvencia empresarial $^{22}$. Sobre este particular Francisco Comín señala que entre 1900 y 1919, la previsión social en España rechazó el modelo alemán de seguro obligatorio y asumió la libertad subsidiada de los modelos italiano y belga ${ }^{23}$. Ese contexto de discrecionalidad otorga gran relevancia a la respuesta de cada empresa ante la nueva norma. La promulgación de esta ley, rápida y por sorpresa, generó una primera oleada de protestas de empresarios y asociaciones patronales ${ }^{24}$. El nuevo escenario pronto hubo de ser asumido, con mayor o menor agrado, e incluso en algunos casos llegó a convertirse en una oportunidad para practicar el paternalismo empresarial ${ }^{25}$.

${ }^{21}$ ESPUNI TOMÁS, J. (2005). "Los accidentes de trabajo: perspectiva histórica". IUS Labor, $\mathrm{n}^{\mathrm{o}} 3$. En línea, disponible en: http://www.upf.edu/iuslabor/032005/art16.htm

22 MARTÍNEZ QUINTERO, E. (1984). "El nacimiento de los seguros sociales en el contexto del reformismo y la respuesta del movimiento obrero". Studia historica. Historia contemporánea, pp. 61-83, p. 76.

${ }^{23}$ COMÍN COMÍN, F. (2010). "Los seguros sociales y el estado del bienestar en el siglo XX". En SILVESTRE, J. y PONS, J. (coord.). Los orígenes del estado del bienestar en España, 1900-1945: los seguros de accidentes, vejez, desempleo y enfermedad. Zaragoza: Universidad de Zaragoza, p. 25.

${ }^{24}$ SILVESTRE, J. y PONS, J. (2008). "El seguro de accidentes del trabajo, 1900-1935. El alcance de las indemnizaciones, la asistencia sanitaria y la prevención”. p. 15. [en línea]. [Consulta 7/05/2013]. Disponible en: file://C:/Users/Usuario/Downloads/DialnetElSeguroDeAccidentesDelTrabajo19001935-2942285.pdf

${ }^{25}$ Programa estructurado y sistemático de captación, formación y control de la mano de obra industrial. Trata de transmitir que, ante un patrón bondadoso y comprensivo, el obrero le debe respeto e incluso afecto, con un sentido de compromiso vertical. El paternalismo minero asturiano ha sido un fenómeno ampliamente estudiado por autores como: SIERRA ÁLVAREZ, J. (1990). El obrero soñado. Ensayo sobre el paternalismo industrial (Asturias, 18601934). Madrid: Siglo XXI; o MUÑIZ SÁNCHEZ, J. (2006). Genealogías del paternalismo minero contemporáneo. Gijón: Trea. 


\section{EL TRATAMIENTO DE LOS ACCIDENTES MINEROS EN LA SOCIEDAD ANÓNIMA MINAS DE RIOSA.}

La Sociedad Anónima Minas de Riosa contrató, en diciembre de 1901, un seguro colectivo de accidentes en el trabajo con la Caja de Previsión y Socorro ${ }^{26}$. Esta entidad, como la mayor parte de las compañías aseguradoras, durante un periodo determinado de su singladura profesional también se ocupó de los accidentes de trabajo. En Asturias su principal foco de atención fue la minería ${ }^{27}$. Con anterioridad a la suscripción de este seguro, la Sociedad ejercía cierta protección hacia sus obreros a través de una partida presupuestaria dedicada al auxilio de los enfermos y heridos ${ }^{28}$. No hemos encontrado ninguna póliza similar en los fondos documentales de empresas mineras contemporáneas $^{29}$. Tan sólo una carta recibida por el director de la Hullera Española, fechada octubre de 1900, en la que el representante de La Iberia intenta persuadirle de la conveniencia de establecer relaciones con ellos ${ }^{30}$.

La póliza del seguro contratado, conservada en el archivo de la empresa y que reviste gran interés para el conocimiento de esta materia, señala que, aunque el asegurado es la Sociedad Anónima Minas de Riosa, se entiende como beneficiario la

26 ARIDEA/GF-MR.Personal.1180/2. Ésta había sido constituida en Barcelona en abril de 1898. Su objeto es la de aseguradora y reaseguradora en los principales ramos del negocio y se dedicaba a la actividad CNAE de agencias de seguros, corredurías seguros. Podemos conocer la importancia social de algunos de los socios de la Caja de Previsión y Socorro gracias al Anuario Financiero y de Sociedades anónimas del año 1924, que ha sido recogido por: PONS PONS, J. (2006). "El seguro de accidentes de trabajo en España: de la obligación al negocio (1900-1940)". Investigaciones de historia económica, nº 4, pp. 77-100. [en línea]. [Consulta 2/7/2014].

Disponible

en: http://www.aehe.net/publicaciones/ihe/archivos/ihe4/AR 03 Pons Jeronia N4 Pp77-

100.pdf., p. 93. La compañía contaba, en el momento de la suscripción de la póliza, con un capital de un 1.500.000 de pesetas. ARIDEA/GF-MR.Personal.1180/2. Jeronia Pons señala que esta cantidad se mantuvo, al menos, hasta 1940: PONS PONS, J. (2003). "Las entidades aseguradoras y la canalización del ahorro en España 1908-1940”. Revista española de seguros, $\mathrm{n}^{\mathrm{o}} 115$, pp. 337-360 [en línea]. [Consulta 2/7/2014] Disponible en:http://www.unizar.es/eueez/cahe/pons.pdf, p. 18.

${ }^{27}$ El hecho de que esta aseguradora tuviese una fuerte presencia en nuestra región en el sector de la minería creemos que se debía a que el delegado provincial de la misma conocía a muchas personas relacionadas con las actividades extractivas.

${ }^{28}$ ARIDEA/GF-MR. Administración. 1139/2.

${ }^{29}$ Se ha comprobado los archivos de las siguientes empresas: Sociedad Hullera Española, Hulleras e Industrias (HULLASA), Minas de Lieres y Sociedad Metalúrgica Duro Felguera. ${ }^{30}$ AHH. SHE. 194/9. 
persona llamada a recibir la indemnización, sea la víctima de un accidente, sean las personas que a ella tengan derecho conforme a las condiciones de la póliza ${ }^{31}$. Se hace con el objeto de indemnizar el perjuicio material ocasionado por un accidente sufrido por los obreros del asegurado durante el ejercicio del trabajo, industria, o profesión considerados en el contrato ${ }^{32}$. El seguro se extiende a todas las personas asalariadas por el asegurado que vayan incluidos en las listas u hojas de pago, pero impide que en éstas se incluyeran más empleados facultativos que los capataces de minas, con lo que el médico, por ejemplo, quedaría fuera. Lo mismo ocurría con las personas no comprendidas en las edades que señalan las leyes vigentes ${ }^{33}$. Durante la Restauración, la gestión de los accidentados se incluyó en las preocupaciones empresariales articulándose medidas dentro del marco general del llamado paternalismo empresarial ${ }^{34}$. La Sociedad Minas de Riosa no sólo no se sustrae a esta corriente, sino que va más allá de lo que obliga la ley, con el fin de obtener una buena imagen ante sus obreros.

Durante los cinco años que duró el contrato con la compañía aseguradora, la Sociedad registraba los heridos en un libro que consta de ciento setenta y un apuntes ${ }^{35}$. Esta información se completa con los partes de baja de los obreros que hemos estudiado hasta reunir un total de ciento ochenta y dos heridos ${ }^{36}$. El $37 \%$ de las lesiones tenían lugar en las extremidades superiores, un $25 \%$ en las extremidades inferiores y un $15 \%$ en el tórax. Este estudio sobre la siniestralidad en las Minas de Riosa reviste un interés que excede del ámbito de la propia Compañía para alcanzar a toda la historia social de la minería, porque ofrece datos que no se encuentran recogidos en ningún otro lugar y contradicen las cifras oficiales. Rafael Fuertes indicó que el número de accidentes del trabajo ocurridos en el año 1901 formado con datos de la estadística del gobierno civil de Oviedo señalaban 16 heridos en las minas, y 15 muertos $^{37}$. Estas

\footnotetext{
${ }^{31}$ ARIDEA/GF-MR.Personal.1180/2.

${ }^{32}$ Para los efectos de la póliza ésta especifica que se entiende por accidente toda lesión corporal que el operario sufra con ocasión o por consecuencia del trabajo que ejecuta por cuenta ajena y fuera de su domicilio. ARIDEA/GF-MR.Personal.1180/2.

${ }^{33}$ ARIDEA/GF-MR. Personal. 1180/2.

34 RODRÍGUEZ OCAÑA, E. y MENÉNDEZ NAVARRO, A. (2005). "Salud, trabajo y medicina en la España del siglo XIX. La higiene industrial en el contexto antiintervencionista". Archivos de Prevención de Riesgos Laborales, 8 (2): p. 58.

${ }^{35}$ ARIDEA/GF-MR. Personal. 1177/1.

${ }^{36}$ ARIDEA/GF-MR. Personal. 1175/6.

${ }^{37}$ FUERTES ARIAS, R. (1902). Asturias industrial. Estudio descriptivo del estado actual de la industria asturiana en todas sus manifestaciones. Gijón: Imprenta de la Cruz, p.121.
} 
cantidades distan mucho de la realidad. En aquellos momentos - también más adelante- las compañías mineras solían ocultar los datos de accidentes laborales a las autoridades $^{38}$. Además era un tema tabú en la prensa. Si extrapolamos los datos de la Sociedad Anónima Minas de Riosa, a la explotación minera en España, vemos que el índice de siniestralidad era mucho mayor del que las estadísticas recogían. Estudios de otras empresas contemporáneas lo corroboran. El hospital de la Société Minière et Métallurgique de Peñarroya, (Córdoba) atendió en 1902 a 1178 heridos por accidente $^{39}$. En The Riotinto Company (Huelva) las ocultaciones llegaban hasta extremos escandalosos, ya que, en las estadísticas oficiales, figuraban como accidentes para 1911-1912 un total de 161, cuando en realidad se habían producido $6.295^{40}$.

Dentro de los motivos de baja laboral por parte de los obreros en Riosa nos interesan muy especialmente los sucesos que denominaban accidentes colectivos, a pesar de que en ninguno de ellos consta la implicación de más de una persona. Estos casos siguen un procedimiento distinto a una baja por lesión común dentro de la gestión de personal de la empresa. En las declaraciones de estos accidentes siempre intervienen dos testigos ${ }^{41}$, que deben describir las circunstancias del siniestro. Gran parte de los trabajadores no saben escribir y, por tanto, incluyen la fórmula a ruego por no saber firmar los testigos lo hacen ${ }^{42}$. Se pueden constatar un total de diecinueve accidentes que se consideran colectivos, pero sólo cuatro merecieron un expediente propio. Se trata de sucesos singulares, por su gravedad o por las especiales circunstancias que los rodearon, haciendo que para la empresa merecieran una atención especial. Esos lances

${ }^{38}$ El preámbulo del Reglamento de Policía Minera de 1897 incluía las estadísticas de accidentes del año anterior y las cifras que ofrecía -242 los heridos graves y 2061 leves-, nos parecen escasas teniendo en cuenta que se referían a todo el país. La propia norma señalaba: puede asegurarse que la ocultación es mucho mayor en los relativos al número y gravedad de las desgracias acaecidas. ESPAÑA. Real decreto aprobando el reglamento de Policía minera. Gaceta de Madrid núm. 199, de 18 de Julio de 1897, pp. 229-230.

${ }^{39}$ COHEN, A. (1999). "Los registros hospitalarios de una gran compañía minero metalúrgica (Peñarroya, 1902-1950). Una fuente y algunas aplicaciones metodológicas para la historia del trabajo”. Scripta Nova. Revista Electrónica de Geografía y Ciencias Sociales, núm. 40.

${ }^{40}$ PASCUAL SOTO, A. y PÉREZ DE PERCEVAL VERDE, M. (2010). “Asistencia sanitaria en la minería de la sierra de Cartagena-La Unión (1850-1914)". Revista de la Historia de la Economía y la Empresa, IV, p. 98.

${ }^{41}$ ARIDEA/GF-MR.Personal.1177/1 y ARIDEA/GF-MR. Personal. 1177/2. Una notación a pie de página en el propio formulario normalizado exige que se incluya nombre, apellidos, profesión y domicilio de los declarantes.

${ }^{42}$ ARIDEA/GF-MR.Personal.1177/2. 
fueron documentados por la Sociedad Anónima Minas de Riosa con una pulcritud reseñable ${ }^{43}$. Los expedientes individualizados son: Expediente del accidente laboral de Pedro Villa y Otero ${ }^{44}$, primer caso de accidente laboral en la empresa; Expediente de accidente laboral de Jesús Muñiz Díaz ${ }^{45}$; Expediente laboral de Ramón Fernández ${ }^{46}$, y la primera defunción en la empresa, que acaeció a Miguel García ${ }^{47}$. Todos estos tienen elementos, al margen de la gravedad intrínseca de los siniestros a los que obedecen, que los hace dignos de una breve mención para valorar las actuaciones de la empresa en los temas relacionados con su personal.

\subsection{El primer accidente: Pedro Villa Otero}

En el primer caso de siniestro laboral ocurrido en la Sociedad Anónima Minas de Riosa destaca la minuciosidad con que se fue conformando el expediente de dicho suceso. En el formulario normalizado, que dejaba constancia de las incidencias por motivos de baja, se señala que Pedro Villa Otero, de cuarenta y ocho años, casado, de Olloniego, con un salario de 3,75 pesetas, ha sufrido un accidente que le produjo dos heridas en la cabeza inciso-contusas que interesa a los tejidos blandos hasta el periostio inclusive y otra contusa en la región dorsal con lesión medular que le imposibilitan para el trabajo. A continuación incluye el lugar y circunstancias del siniestro con las siguientes palabras: en ocasión de que se hallaba trabajando en términos de la Pereda en el ensanche de una trinchera donde hay instalada una vía férrea. El documento aparece fechado en La Pereda a 28 de enero de 1902 y sin firma. A continuación se adjunta el informe del vigilante, Ildefonso Junquera, donde se señala que el médico, Angel Bueres le visitará y le asistirá hasta su restablecimiento ${ }^{48}$.

Se conserva la carta dirigida al alcalde constitucional de Mieres en cumplimiento del Reglamento para la aplicación de la Ley de Accidentes del Trabajo vigente en el

\footnotetext{
${ }^{43}$ En la documentación conservada de otras empresas también pueden encontrarse expedientes de accidentes pormenorizados, con todos los documentos acreditativos. Tal es el caso de la Sociedad Hullera Española, en el expediente de la explosión ocurrida en Marianas a 21 de octubre de 1902, cuando se produjo una detonación a causa de la llama de la lámpara. (AHH.SHE.17/1).

${ }^{44}$ ARIDEA/GF-MR. Personal. 1177/2.

${ }^{45}$ ARIDEA/GF-MR. Personal. 1177/3.

${ }^{46}$ ARIDEA/GF-MR. Personal. 1177/4.

${ }^{47}$ Este último se encontró dentro de la unidad documental compuesta conformada por este propio expediente y el libro registro de altas y bajas de heridos. ARIDEA/GF-MR. Personal. $1177 / 5$.

${ }^{48}$ ARIDEA/GF-MR.Personal.1177/2.
} 
momento que, en su artículo octavo, reseña que el patrono, en un plazo que no exceda de veinticuatro horas, dará conocimiento del mismo a la autoridad gubernativa (en este caso el alcalde $)^{49}$. En la misiva el ingeniero, en representación de la Sociedad Minas de Riosa, participa a la Alcaldía de que ese mismo día, a las tres de la tarde y en el término del pueblo de La Pereda, ocurrió un accidente que produjo varias heridas al obrero Pedro Villa y Otero que trabajaba en las obras de una trinchera para la instalación de la vía férrea, siendo testigos del accidente José Díaz y Suárez y Severo Madera y Álvarez, ambos mayores de edad ${ }^{50}$. Continúa el relato señalando que se trasladó al herido a la casa-oficina habilitada provisionalmente como hospital y fue reconocido por el facultativo de la Sociedad, Ángel Bueres, que habita en el pueblo de Riosa, que envía certificación cuya copia adjunta. En una misiva posterior, fechada el 10 de octubre de 1902 y dirigida al director de las Minas en Ablaña (Mieres), el facultativo Nicolás Real señala los daños que sufre el obrero Pedro Villa, de quien se hizo cargo al tomar posesión de su plaza. A consecuencia de una contusión en la columna vertebral se encuentra incapacitado parcial, aunque permanente para dedicarse al trabajo que venía desempeñando y sin necesidad de más asistencia facultativa a no ser que como consecuencia del traumatismo sobrevenga más tarde alguna complicación que no esté presente en ese momento ${ }^{51}$, dándosele el alta. El paciente no está conforme con los diagnósticos de los médicos de la empresa y, acogiéndose al derecho que le da la ley, acude a otro médico, concretamente a Arturo Buylla y Alegre ${ }^{52}$, que certifica, con fecha 16 de octubre de 1902, que el obrero se

${ }^{49}$ En ese aviso era obligatorio hacer constar la hora y el sitio en el que ocurrió el accidente, cómo se produjo, quiénes lo presenciaron, el nombre de la víctima, el lugar a que ésta hubiera sido trasladada, nombre y domicilio del Facultativo o Facultativos que practicaron la primera cura, el salario que ganaba el obrero y la razón social de la Compañía Aseguradora cuando exista contrato de seguro. ESPAÑA. Reglamento para la aplicación de la ley de 30 de enero de 1900 acerca de accidentes del trabajo. Gazeta de 30 de Julio de 1900.

${ }^{50}$ ARIDEA/GF-MR.Personal.1177/2.

${ }^{51}$ ARIDEA/GF-MR.Personal.1177/2.

52 Arturo Álvarez Buylla y González Alegre, nacido en Oviedo en 1852, fue un médico destacado a finales del siglo XIX y principios del XX, conocido como uno de los fundamentales impulsores de la higiene social en Asturias, siendo el autor de uno de los pocos textos que en siglo XIX se dedicó por entero a la higiene del obrero. Desarrolló además una importante labor divulgativa sobre las propiedades curativas de las aguas, participando asiduamente en numerosos congresos y abogando por la generalización de las prácticas higiénicas. Presidió el Colegio de Médicos de Asturias y la Cámara de la Propiedad, fue vicepresidente de la Asociación Médico-Farmaceútica de Asturias y secretario de la Sociedad Económica de Amigos del País. Como político ocupó el cargo de concejal y diputado provincial por Oviedo 
encuentra imposibilitado para el trabajo por varias lesiones en la columna vertebral, costillas y esternón que comprometen órganos importante y le impiden no sólo hacer esfuerzos sino también permanecer de pie mucho tiempo. Ante el silencio de la empresa, los días 24 y 27 de noviembre Pedro Villa escribe a la dirección de la misma, afirmando que, si no se le comunica que sus legítimos derechos serán atendidos, pondrá el asunto en manos de los tribunales de justicia ${ }^{53}$.

El 4 de diciembre de 1902, el médico Nicolás Real se dirige al director de la Caja de Previsión y Socorro de Barcelona, que en su calidad de aseguradora, desea conocer la situación real del herido. En esta carta el facultativo responde a las preguntas que, a través del director gerente de la Sociedad Minas de Riosa, le hace la aseguradora respecto al herido Pedro Villa Otero ${ }^{54}$. La aseguradora entonces responde, a través de la persona de Luis Ariño, delegado de la entidad en Gijón, con fecha 17 de diciembre de 1902, a Aquiles Paternottre. Se deja constancia de que a Pedro Villa Otero debe indemnizársele con dieciocho meses de jornal. La cantidad total a pagarle, -tenía un sueldo de 3,73 pesetas diarias, a las que habría que añadir el medio jornal correspondiente al periodo de baja- sería, aproximadamente, de 1.800 pesetas. Si el interesado se conforma con esa cantidad, no tiene ningún inconveniente en pagarle, siempre que firme un recibo de acuse y una declaración de que no solicitará a posteriori nuevas indemnizaciones. Recomienda encarecidamente rapidez en las gestiones con el fin de pedir a la sede central de la Caja de Previsión la orden de pago telegráficamente. Señala que en realidad ese lesionado lo es de segundo grado y no de primero, según la opinión de los médicos a los que consultó nuevamente el asunto.

Sin embargo Pedro Villa no está conforme con que se le quiera abonar con dieciocho meses, afirma tener derecho a veinticuatro meses de indemnización, además de otros cuatro meses desde el 10 de octubre hasta el 28 de enero. Basa su alegato en que un facultativo le había diagnosticado impedido para todos los trabajos y así lo había hecho constar en una carta fechada el 18 de octubre de 1902. A posteriori otra carta de Luis Ariño, con fecha 26 de diciembre de 1902 al director de las Minas de

\footnotetext{
desde 1909 hasta su muerte. Más información en: FERNÁNDEZ ARBÁS, O. (2006). Saludy trabajo en Asturias (1775-1932). Tineo: Asociación Cultural Conde de Campomanes.

${ }^{53}$ ARIDEA/GF-MR.Personal.1177/2.

${ }^{54}$ Concretamente quiere que se le precisen las siguientes cuestiones: la clase de lesiones de la columna vertebral, esternón y costillas (...) Saber si hubo fractura de alguno de estos órganos $y$, en caso afirmativo, si la consolidación ha sido viciosa (...) especificar los desórdenes de comprensión en el aparato respiratorio y circulatorio y el funcionalismo de la vejiga y el del tubo digestivo. RIDEA AMR. 1177/2.
} 
Riosa, indica que la Caja de Previsión y Socorro, a quien representa, está dispuesta a cumplir el compromiso entregando al obrero la indemnización que corresponda, con lo que no está de acuerdo es con la exigencias del accidentado que no debe tener un buen asesor, puesto que le lleva por un camino que seguramente no ha de conducirle a buen fin cuya causa es el absoluto desconocimiento de la Ley de 30 de enero de 1900 y su reglamento Cita la carta los artículos que en su opinión no está teniendo en cuenta el obrero en su reclamación, y señala que sólo cuando la compañía aseguradora no haya cumplido estrictamente lo señalado por la Facultad de Medicina de Valladolid, que es la llamada a resolver esa cuestión, podrá el obrero Pedro Villa llevar a los tribunales el asunto. Aún así determina que, aunque con arreglo a la calificación sólo debía recibir 1687,50 pesetas, si el obrero transige y firma la conformidad, renunciando a posteriores reclamaciones, se le abone el resto hasta completar las 2.000 pesetas. Esta generosidad de la compañía se justificaba, según sus palabras, en honor a esa sociedad con el fin de salir de una vez de este enojoso asunto (...) mucho siento que por causa de este individuo sufra $V$. tanta molestia. Creemos que es más que probable que no desearan verse involucrados, en un momento tan temprano de su andadura empresarial, en un proceso judicial relacionado con la flamante ley que se ocupaba de los accidentes laborales. En el certificado médico de alta Pedro Villa rubrica la fórmula a entera satisfacción del afectado de incapacidad de segundo grado $o^{55}$.

\subsection{El caso de Jesús Muñiz Díaz}

Este nuevo sumario de un siniestro laboral en la empresa contiene los tres documentos clásicos de los partes de incidencias por herida o accidente: en primer lugar el formulario, con fecha del 13 de agosto de 1902 y firma de Ángel Bueres, médico del grupo San César. El facultativo certifica que el operario Jesús Muñiz Díaz, de Felguera, en el día de hoy ha sufrido fractura del mulso por su tercio inferior y una herida contusa con gran pérdida de tejido en el tercio inferior derecho del brazo, con gran hemorragia y que tardará en curar de mes y medio a dos meses ${ }^{56}$. En segundo lugar figura el impreso para escribir a la Caja de Previsión y Socorro de Barcelona, con fecha 15 de agosto de 1902. En éste se indica que, de conformidad a las condiciones de la póliza n $n^{\circ} 2426$, se participa que Jesús Muñiz Díaz, de dieciséis años de edad, personal asalariado en calidad de pinche, de estado civil soltero y con un salario de 1,75 pesetas, ha sufrido un accidente; no se ofrece más información al respecto. Por último, el modelo con el título Socorro a los Heridos, con fecha 13 de

\footnotetext{
${ }^{55}$ ARIDEA/GF-MR.Personal.1177/2.

${ }^{56}$ ARIDEA/GF-MR.Personal.1177/3.
} 
agosto, consigna que el facultativo Ángel Bueres visitará a Jesús Muñiz Díaz, que vive en Felguera, Riosa, por contusión ${ }^{57}$. En éste se señala que pertenece al grupo San César, que ha sido visitado el día trece por fractura en el muslo y herida y que ha sido dado de alta el 2 de marzo de 1903. Como vemos las previsiones iniciales del médico habían sido muy optimistas, porque frente al mes o mes y medio que indicaba en su primer diagnóstico, la baja ha ocupado seis meses y medio. En ese tiempo el herido, así como el trato que recibió, fue objeto de atenciones y controversias de interés relevante para conocer la política de la empresa en materia de personal. En una carta del médico, Ángel Bueres, fechada en Riosa el 21 de agosto de 1902 y dirigida a Aquiles Paternottre, se indica: en contestación a su atenta del 20 debo decirle que el herido Jesús Díaz por quien $V$. se interesa sigue bien de la herida del brazo y en cura la fractura del muslo, el estado general es satisfactorio teniendo en cuenta la gravedad de las lesiones. Añade que le hace la cura diaria, y que se está al tanto de su estado con interés. En esta misiva aparecen varios puntos muy significativos para percibir la asistencia a los obreros por parte de la Sociedad. Por un lado se produce un hecho inaudito hasta donde se ha podido saber ya que indica: hasta ahora hizo falta un peón al lado del enfermo que es un hermano suyo para ir por medicinas y moverle en la cama, cuando no haga falta ya le mandaré siga trabajando en las minas ${ }^{58}$. La Sociedad está pagando al hermano del herido por cuidarle. Esta situación no es obligatoria por ley, ni entonces ni siquiera ahora. En la misma carta el médico solicita que es preciso pongan cuanto antes algo de botiquín aqui pues la primera cura de urgencia se la hice con medicamentos que yo tenía en mi botiquín particular. Parece que el botiquín no sólo no estaba bien surtido, sino que en ese momento ni siquiera existía. La última frase significativa señala que urge pongan pronto en condiciones una o dos camas en Canales para cuando ocurra algún accidente. La empresa no posee botiquín ni tampoco un servicio de enfermería o al menos unas camas para recostar a los heridos que se puedan dar en el grupo San César, que alberga la explotación de Canales, sin embargo, y una vez ocurrido el siniestro, se ocupa de la atención del herido con una diligencia y unas atenciones poco comunes. Esto nos lleva a preguntarnos por los motivos a los que obedece tal actitud, y no deja de ser posible que se deba al interés en acallar la conciencia y las voces que pudieran hacerse eco de la citada carencia de botiquín.

\footnotetext{
${ }^{57}$ La palabra contusión aparece como parte del formulario normalizado y, por tanto, recogería cualquier herida o percance físico que haya sufrido el obrero.

${ }^{58}$ ARIDEA/GF-MR.Personal.1177/3.
} 
A continuación se incluye en el expediente una carta del médico Ángel Bueres fechada en Riosa el 24 de agosto de 1902 y dirigida a Aquiles Paternottre en Ablaña, donde manifiesta que el herido sigue mejorando y que su estado es satisfactorio. Continúa el médico precisando, en referencia a algún comentario que el director de la empresa le había hecho en una misiva propia que no se ha conservado, y señala que está $V$. mal informado de que a éste herido se le hizo la primera cura al día siguiente del accidente, puesto que pocos momentos después de ocurrido ya lo supongo, estando yo en mi casa y subi con los que llevaban la camilla a Felguera y practiqué la primera cura como a los tres cuartos de hora después del percance. Parece que se ha puesto en cuestión la profesionalidad del doctor y que éste se siente atacado. No conviene olvidar que el médico lo es de la empresa, además de municipal, de hecho es la Sociedad quien le abona la mayor parte de sus emolumentos y es a ella a quien se debe antes, por eso continua con su correspondencia regular dirigida a Aquiles Paternottre para dejar clara su diligencia ${ }^{59}$. El 17 de diciembre de 1902 manifiesta que Jesús Muñiz sigue bien y apoya el muslo que quedó al parecer en buenas condiciones. Desde hoy procuraré cumplir su deseo en mandarle las cartas y avisar por el vigilante Nicolás. Ordene en cuanto se le ofrezca y pueda serle útil a $\mathrm{ss}^{60}$.

En una misiva posterior, con fecha 10 de octubre de 1902, Ángel Bueres Escribano escribe a Aquiles Paternottre y le da cuenta de todos los progresos del herido, le habla de la situación del hermano de éste, que ya ha sido requerido para incorporarse a su puesto de trabajo habitual en la mina y, al parecer, no se ha presentando.

59 A lo largo de estos dos meses el médico dirigirá a Aquiles Paternottre más misivas con información de otros heridos que en el resto del periodo documentado. Algunos ejemplos podrían ser:

- 1 de septiembre de 1902: tiene el gusto de manifestarle que el herido Jesús Díaz tiene casi curada la herida del brazo el citado general es más satisfactorio creo está fuera de peligro.

- $\quad$ Sin fecha: tiene el gusto de participarle que el herido de hoy, Diego Muñoz no ofrece gravedad alguna y sido curado el mismo día de venir el accidente. El otro Jesús sigue bien.

- $\quad 21$ de octubre de 1902: le comunico que el herido Manuel Díaz fue curado el mismo día en que se hirió y que desearía saber por qué el capataz Manuel Fernández manda al herido atestiguar mi ausencia si no estoy en casa al llegar el y qué objeto se propone con ello. El otro Fernández Díaz ya se levanta y anda sobre muletas.

- $\quad 24$ de octubre de 1902: tiene el gusto de manifestarle que el herido de hoy, Francisco Tuñón, no ofrece gravedad en la herida que recibió en la cabeza. Los demás siguen mejorando rápidamente.

${ }^{60}$ ARIDEA/GF-MR.Personal.1177/3. 
Confirmo a V. mi carta en la que le señalaba la fecha en que debía esperar a trabajar el hermano del herido Jesús Muñiz Díaz y como no fue, creo deben abonarle hasta dicha fecha el jornal por estar como yo le dije asistiendo a su hermano. Yo no recuerdo dich a fech a pero supongo $V$. la habrá anotado o conservará mi carta en la que lo decía (...) el herido se levanta y anda sobre muletas por el pueblo, creo queda bien. Como le dejo dicho debe $V$. tener una carta en la que le decía hace bastantes dias el día en que mandé trabajar al hermano, y si por casualidad no llegó a sus manos yo averiguaré la fecha y se la mandaré a decir, no creo dudará $V$. de mi que dejé un momento del mirar por los interesas de la compañia que me da el pan. Vds. no deben abonarle más días que hasta aquel en que yo le mande trabajar pues si no fue a la mina no sería por yo ordenarlo pues el mismo día en que le dije no se le necesitaba le escribi a $V$. (...) el herido se curó el mismo día y sigue curándose a diario hasta ahora con medicinas que yo tenía por no tener tiempo de ir por ellas ello repito ${ }^{61}$.

Con fecha 21 de octubre de 1902 el médico participa al ingeniero que el herido sigue bien del resultado de sus heridas y de la factura del muslo, puesto que ya anda sin muletas y creo quede sin imperfección alguna.

\subsection{Expediente del siniestrado Ramón Fernández}

En carta estandarizada para la Caja de Previsión y Socorro, fechada en La Pereda el 2 de agosto de 1903, la Sociedad Anónima Minas de Riosa, de conformidad con la póliza suscrita, le participa que Ramón Fernández, operario de doce años y medio de edad, de estado civil soltero, natural y vecino del Corigón, parroquia de Loredo, concejo de Mieres, y con un salario de 1,50 pesetas, el día 21 ha sufrido un accidente y presenta fractura completa y abierta del fémur derecho en su tercio medio y superior y una herida de unos $20 \mathrm{~cm}$ de longitud inciso contusa que deja al descubierto la tibia y el peroné y otra en la región calcánea de unos $3 \mathrm{~cm}$ de longitud, producidas todas por contusión; el estado general satisfactorio relativamente ${ }^{62}$. Cabe destacar el hecho de que ningún otro de los partes de baja contiene una puntualización de la edad de los afectados por debajo del año natural; no se han encontrado partes de un herido de

\footnotetext{
${ }^{61}$ ARIDEA/GF-MR.Personal.1177/3.

${ }^{62}$ ARIDEA/GF-MR.Personal.1177/4.
} 
veintiocho años y medio o de cuarenta y cinco y medio. Esta precisión puede obedecer a una artimaña psicológica para intentar que la percepción de la edad del herido sea superior a la que es. A pesar de que la legislación vigente permite el trabajo a los mayores de 10 años, no considerándolos a partir de esa edad como niños, al menos a efectos laborales, lo cierto es que señalar que hay un obrero herido de gravedad de doce años de edad ya en esos momento era lo que hoy en día se denomina "políticamente incorrecto". Las primeras curas fueron realizadas por dos médicos, Nicolás Real y Ángel Bueres. Estos, en el parte médico presentado a la Caja de Previsión y Socorro, fechado en La Pereda el 21 de agosto de 1903, señalan que han visto y reconocido al obrero, operario de los trabajos exteriores de las Minas de Riosa ${ }^{63}$. No se ha encontrado en la documentación conservada de la empresa ningún herido atendido a la vez por dos médicos. Si es cierto que así ocurrió, y no hay indicios para pensar lo contrario, hace ver que en ese mismo momento se consideró este accidente un caso singular. Habida cuenta de que el estado del lesionado no es más grave que los casos de Pedro Villa o Jesús Muñiz, ese interés de los facultativos ha de obedecer necesariamente a la edad del herido. Por si fuera poco, no es raro que en el parte de baja se señalen las circunstancias del accidente, pero lo común es hacerlo en una hoja de declaración de accidente colectivo, no en el parte de baja propiamente, ni en la hoja normalizada que se envía a la aseguradora. En este caso la frase operario de los trabajos exteriores quiere dejar claro que Ramón Fernández no se encontraba en el interior de las minas, ya que esto podría no estar contemplado, y ser motivo de anulación de la póliza, por parte de la compañía aseguradora según aparece en una cláusula de la misma $^{64}$. Antonio Sempau, en calidad de ingeniero director facultativo de la Sociedad Anónima Minas de Riosa, participa el accidente al gobernador civil de la Provincia ${ }^{65}$, concretando que el siniestro se produjo a las siete horas y treinta minutos de la mañana cuando Ramón Fernández y Zapico se encontraba prestando servicio en el cargue de coque, trabajando seis horas y media al día ${ }^{66}$. El accidente fue producido por un vagón que estaban colocando para el cargue en las instalaciones sitas en este pueblo de La Pereda. Cita como testigos a Emilio Fernández y Benjamín Menéndez y señala que fue

\footnotetext{
${ }^{63}$ ARIDEA/GF-MR.Personal.1177/4.

${ }^{64}$ ARIDEA/GF-MR.Personal.1180/2.

${ }^{65}$ ARIDEA/GF-MR.Personal.1177/4.

${ }^{66}$ En este sentido, según la ley los niños con edades comprendidas entre los diez y los catorce años pueden trabajar durante una jornada que no exceda de las seis horas. Sorprende que se haya señalado aquí que pasen de las seis aunque sea sólo por media hora.
} 
trasladado de forma inmediata ${ }^{67}$ a su hospital provisional situado en La Pereda, haciéndole la primera cura los dos médicos de la empresa ${ }^{68}$.

\subsection{La primera defunción en la empresa.}

Se conserva la documentación que informa del primer caso de accidente con muerte en la empresa y así aparece titulado en la carpetilla original que acogía el sumario. Reviste un especial interés para conocer el modo de tratar estas situaciones, tanto desde el punto de vista concreto de la Sociedad Minas de Riosa, como desde la perspectiva empresarial y estatal general, al mostrar la legislación vigente los pasos a seguir ante esta eventualidad. El luctuoso suceso se data el 21 de mayo de $1901^{69}$. En un primer lugar encontramos una misiva dirigida al Ingeniero Jefe del Distrito de Oviedo, de ese mismo día, en la que se señala que, a las cuatro de la tarde, ocurrió en La Pereda un accidente que causó la muerte al obrero Miguel García, que trabajaba en las obras de un plano inclinado en construcción. La misiva cumple el artículo veinticuatro del Reglamento vigente en el momento de Policía Minera ${ }^{70}$. Dos días más tarde respondió Miguel Aldecoa, señalando que el Ingeniero Jefe del Distrito de Oviedo iba a ordenar a una persona hacer una visita de inspección. El operario víctima del accidente ganaba un jornal de 2,75 pesetas, era natural de Marentes, Ibias, tenía 23 años de edad, hijo de Manuel y de María, de estado civil casado y de oficio jornalero. También se conserva, como se ha observado en el resto de accidentes documentados, la comunicación al alcalde constitucional de Mieres, en calidad de autoridad gubernativa del lugar en el que se produjo el fatal suceso ${ }^{71}$. Paternottre, el ingeniero, suscribe la misma en representación de la Sociedad de Minas de Riosa con el fin de avisar a la alcaldía la muerte del operario. En esta comunicación, como era preceptivo, se ofrece una información que no había sido dada en la documentación anterior sobre las circunstancias del fallecimiento. En primer lugar la hora exacta, las dieciséis horas; el lugar, llamado la Fuente de Valencia, y la razón concreta de la muerte, a causa de la

${ }^{67}$ Nótese el interés en clarificar la rapidez en la atención al operario.

${ }^{68}$ ARIDEA/GF-MR.Personal.1177/4.

${ }^{69}$ ARIDEA/GF-MR.Personal.1177/5.

${ }^{70}$ Según el cual los explotadores de la misma darán cuenta al ingeniero jefe de distrito o al ingeniero que estuviese más próximo de cualquier accidente ocurrido en las minas o en sus dependencias que hubiese producido la muerte o heridas graves, a juicio de un médico, a una o varias personas.

${ }^{71}$ El formulario normalizado en el que se ha hecho la comunicación a la alcaldía posee el membrete original de la Sociedad Tres Amigos, a la que se le tacha dicho nombre y se sustituye por Minas de Riosa. 
caída de un árbol. Los testigos del accidente fueron Segundo Jano, Manuel Barrero, Genaro Rivera y Manuel Pérez ${ }^{72}$. El cuerpo del interfecto fue trasladado al cementerio parroquial, donde fue reconocido por el facultativo Celestino Muñiz Prieto ${ }^{73}$, que certificó la muerte ${ }^{74}$. En el traslado de la información a la alcaldía, en hoja sellada y fechada, se incluye alguna información adicional, no encontrada en los otros borradores: se afirma que no tenía familia, refiriéndose esa expresión siempre a vástagos, porque sí que tenía esposa y padres; el difunto trabajaba de peón de explanación de vías por cuenta del contratista José Campos, vecino de Ablaña, que ejecutaba la obra indicada para de la Sociedad y ganaba un jornal de 2,75 pesetas, trabajando once horas diarias. Sin duda el documento más interesante de este expediente es la autopsia certificada enviada a la alcaldía por Celestino Muñiz Prada y Prieto. En ella consta un sello original de entrada y el recibí del ayuntamiento de Mieres con fecha 24 de mayo de 1903 y concluye: (...) el individuo en cuestión falleció a consecuencia shock traumático (...) su muerte debió de ser instantánea y dichas lesiones debieron de ser producidas por un cuerpo duro y pesado ${ }^{75}$.

\section{CONCLUSIONES}

Los expedientes descritos tienen en común elementos que van más allá de lo puramente formal. Se trata del desvelo, más o menos interesado, de la Sociedad Anónima Minas de Riosa por cada uno de los casos, cuya gravedad los hacía especialmente sensibles. Este celo se relaciona con su actitud general hacia la atención médico-asistencial a sus obreros, que ya puede adivinarse en actitudes previas a la promulgación de la Ley de Accidentes del Trabajo, pues la empresa ejercía cierta protección hacia sus obreros a través de una partida presupuestaria dedicada al auxilio de los enfermos y heridos. Aunque en la Empresa hubo cientos de partes de bajas y diecinueve accidentes colectivos, sólo los cuatro sucesos estudiados merecieron su atención por la gravedad, en un sentido u otro, del siniestro. En todos ellos se reseñaron las actuaciones de la empresa y los afectados, con total minuciosidad, y adecuándose

\footnotetext{
72 Adviértase la presencia de la firma de cuatro testigos en vez de los dos habituales.

${ }^{73}$ Este es uno de los facultativos que se encargaba de los heridos de la Sociedad antes de la incorporación de un médico de la empresa en la figura de Ángel Bueres.

${ }^{74}$ La copia del certificado de defunción, que expide el facultativo, señala que puede hacerse el correspondiente asiento en el Registro, en cumplimiento con el artículo $181^{a}$ disposición del Reglamento para la aplicación de la Ley de Accidentes del Trabajo. ARIDEA/GFMR.Personal.1177/5.

${ }^{75}$ ARIDEA/GF-MR. Personal.1177/5.
} 
a la normativa vigente (notificación a las diferentes autoridades gubernativas, vigilancia de la situación de los heridos, comunicación continua con la compañía aseguradora, etc.).

Debemos destacar que suscribió un seguro colectivo de accidentes en el trabajo con la Caja de Previsión y Socorro de Barcelona en un momento en que tal actuación, si bien recomendable, no era obligatoria para los empresarios. Aunque esa previsión podía obedecer a intereses egoístas, para protegerse como empresa, lo cierto es que nos demuestra la atención que le merece la seguridad de sus trabajadores, en clara consonancia, por otro lado, con el paternalismo industrial, -entendido éste como el ejercido por el patrono que adopta una actitud benevolente hacia sus trabajadores-., imperante en aquellos momentos. La principal motivación era la escasez de picadores que sufrían, haciendo necesario dar a éstos incentivos de algún tipo, para retenerlos en su yacimiento, y evitar que se dejaran tentar por otras compañías ${ }^{76}$.

La empresa tiene en general un alto sentimiento de responsabilidad hacia sus obreros una vez éstos han resultados heridos. Se preocupa de su bienestar una vez acontecido el siniestro, llegando en algunos extremos a pagar jornales porque atiendan a los impedidos. Así mismo destaca la atención médica recibida. Los galenos visitan casi a diario a los enfermos, tanto para hacer las curas como sólo para revisarlos, e informan, con esa misma asiduidad, a la dirección de la Sociedad de los progresos de los pacientes. Estas actitudes, como ya hemos adelantado, no pueden dejar de relacionarse con el paternalismo obrero como forma de relación laboral presente a lo largo de toda la Restauración. Sin embargo adolece de alguna planificación, como no poseer botiquín a pie de explotación, algo que podría solventar muchas pequeñas curas de forma rápida e incluso constituir la distancia entre la vida y la muerte en el caso de que un accidentado precisase atención inmediata para parar una hemorragia, desinfectar una herida, etc.

\section{BIBLIOGRAFÍA}

ARTOLA, M. (1978). Antiguo Régimen y revolución liberal, Barcelona: Ariel.

${ }^{76}$ En una carta de Aquiles Paternottre a Alfredo Santos el día 14 de diciembre de 1902 le señalaba: los picadores que la capa $n^{\circ} 9$ que se han negado a trabajar(...) tiene más cuenta ir a Nicolasa donde ganan un poco más. ARIDEA/GF-MR. Gobierno. 1142/2. 
CLAVERO SALVADOR, B. (1989). "Institución de la reforma social y constitución del Derecho del Trabajo". Anuario de Historia del Derecho Español, LIX, pp. 859-884.

COHEN, A. (1999). "Los registros hospitalarios de una gran compañía minero metalúrgica (Peñarroya, 1902-1950). Una fuente y algunas aplicaciones metodológicas para la historia del trabajo". Scripta Nova. Revista Electrónica de Geografía y Ciencias Sociales, núm. 40.

COMÍN COMÍN, F. (2010). "Los seguros sociales y el estado del bienestar en el siglo XX”. En SILVESTRE, J. y PONS, J. (coord.). Los orígenes del estado del bienestar en España, 1900-1945: los seguros de accidentes, vejez, desempleo y enfermedad. Zaragoza: Universidad de Zaragoza.

ESPAÑA (1873). Ley excluyendo á los niños y niñas menores de 10 años del trabajo en fábricas, talleres, fundiciones ó minas, y fijando las horas de trabajo en las mismas. Gaceta de Madrid núm. 209, de 28 de Julio de 1873.

ESPAÑA (1900). Ley relativa a prevenir los accidentes del trabajo, y forma de indemnizar á los obreros que sean víctimas de dichos accidentes. Gaceta de Madrid núm. 31, de 31 de enero de 1900.

ESPAÑA (1897). Real decreto aprobando el reglamento de Policía minera. Gaceta de Madrid núm. 199, de 18 de Julio de 1897.

ESPAÑA (1883). Real decreto creando una comisión para el estudio de las cuestiones que directamente interesen al bienestar de las clases obreras y que afecten á las relaciones entre el capital y el trabajo, de 5 de diciembre de 1883, Gaceta de Madrid, núm. 344, 10 de diciembre de 1883.

ESPAÑA (1900). Reglamento para la aplicación de la ley de 30 de enero de 1900 acerca de accidentes del trabajo. Gazeta de 30 de Julio de 1900.

ESPAÑA (1903). Real decreto de 23 de abril de 1903 por el que se crea el Instituto de Reformas Sociales. Gaceta de Madrid, núm. 120, 30 de Abril de 1903.

ESPUNI TOMÁS, J. (2005) "Los accidentes de trabajo: perspectiva histórica". IUS Labor, núm. 3. [En línea]. [Consulta 7/05/2013]. Disponible en: http://www.upf.edu/iuslabor/032005/art16.htm

FERNÁNDEZ ARBÁS, O. (2006). Salud y trabajo en Asturias (1775-1932). Tineo: Asociación Cultural Conde de Campomanes.

FERNÁNDEZ GUTIÉRREZ, M.F. (2005), "Minas de Riosa, Asturias: un persistente éxito empresarial (siglos XIX y XX)". En VIII Congreso de 
la Asociación Española de Historia Económica.. [En línea]. [Consulta 7/05/2013]. Disponible en: http://www.usc.es/estaticos/congresos.

FERNÁNDEZ MENÉNDEZ, M. (2015). La Sociedad Anónima Minas de Riosa en la industrialización asturiana (1899 - 1916). Estudio del fondo documental de su archivo empresarial. Tesis doctoral. Universidad de León. Departamento de Patrimonio Artístico y Documental. Dirigida por Carmen Rodríguez López y Jorge Muñiz Sánchez.

FERNÁNDEZ SAN ELÍAS, F. (2011). La prevención de riesgos laborales en el sector de la minería del carbón. Universidad de León. Departamento del derecho privado y de la empresa. Director, Juan José Fernández Domínguez. [En línea]. [Consulta 7/05/2013]. Disponible en: https://buleria.unileon.es

FUERTES ARIAS, R. (1902). Asturias industrial. Estudio descriptivo del estado actual de la industria asturiana en todas sus manifestaciones. Gijón: Imprenta de la Cruz.

MARTÍN VALDERDE, A., RODRÍGUEZ-SAÑUDO GUTIÉRREZ, F. y GARCÍA MURCIA, J. (1991). Derecho del Trabajo. Madrid: Tecnos.

MARTÍNEZ QUINTERO, E. (1984). "El nacimiento de los seguros sociales en el contexto del reformismo y la respuesta del movimiento obrero". Studia Historica. Historia Contemporánea, vol. 2, pp. 61-83.

RAMÍREZ MARTÍNEZ, J.M. (2010). Curso de derecho del trabajo. Valencia: Tirant le Blanc.

MONTOYA MELGAR, A. (2008). Derecho del trabajo. Madrid: Tecnos.

MUÑIZ SÁNCHEZ, J. (2006). Genealogías del paternalismo minero contemporáneo. Gijón: Trea.

PASCUAL SOTO, A. y PÉREZ DE PERCEVAL VERDE, M. (2010). "Asistencia sanitaria en la minería de la sierra de Cartagena-La Unión (1850-1914)". Revista de la Historia de la Economía y la Empresa, IV, pp. 93-104.

PONS PONS, J. (2003) "Las entidades aseguradoras y la canalización del ahorro en España 1908-1940”. Revista Española de Seguros, n 115, pp. 337-360. [En línea]. [Consulta 18/06/2014]. Disponible en: http://www.unizar.es/eueez/cahe/pons.pdf

(2006). "El seguro de accidentes de trabajo en España: de la obligación al negocio (1900-1940)". Investigaciones de Historia Económica, no 4, pp. 77100. [En línea]. [Consulta 7/05/2013]. Disponible en: http://www.aehe.es 
RADA Y DELGADO, J. (1858). Viaje de SS.MM. y AA por Castilla, León, Asturias y Galicia verificado en el verano de 1858. [En línea]. [Consulta 04/05/2013]. Disponible en: http://babel.hathitrust.org

RORÍGUEZ OCAÑA, E. y MENÉNDEZ NAVARRO, A. (2008). "Salud, trabajo y medicina en la España del siglo XIX. La higiene industrial en el contexto antiintervencionista". Archivos de Prevención de Riesgos Laborales, núm. 8 (2).

SIERRA ÁLVAREZ, J. (1990). El obrero soñado. Ensayo sobre el paternalismo industrial (Asturias, 1860-1934). Madrid: Siglo XXI.

SILVESTRE, J. y PONS PONS, J. (2008). "El seguro de accidentes del trabajo, 19001935" En XVI Encuentro de Economía Pública (Granada, 2009). [En línea]. [Consulta 7/05/2013]. Disponible en: http://dialnet.unirioja.es/servlet/autor?codigo $=83746$.

\section{FUENTES PRIMARIAS}

España. Ministerio de Industria, Energía y Turismo. Sede Web institucional http://www.minetur.gob.es/es-ES/Paginas/index.aspx

Fondo Hulleras e Industrias (HULLASA). Archivos de Asturias. Sede Web institucional: http://www.archivosdeasturias.info

Fondo Minas de Lieres. Archivo Histórico de HUNOSA.Sede Web institucional: http://www.sadiminversiones.es/metaspace/portal/47635/49867

Fondo Minas de Riosa. Archivo del Real Instituto de Estudios Asturianos. Sede Web institucional: http://ridea.org/

Fondo Sociedad Hullera Española. Archivo Histórico de HUNOSA.Sede Web institucional: http://www.sadiminversiones.es/metaspace/portal/47635/49867

Fondo Sociedad Metalúrgica Duro Felguera. Archivo Histórico de HUNOSA. Sede Web institucional: http://www.sadiminversiones.es/metaspace/portal/47635/49867

Registro Mercantil y de Bienes Muebles de Asturias. Sede Web institucional: http://www.registradores.org/ 


\title{
DIFUSIÓN Y EVALUACIÓN DE LA INVESTIGACIÓN HISTÓRICA EN LA ERA DIGITAL: REVISTAS ESPAÑOLAS Y BASES DE DATOS
}

\section{DISSEMINATION AND EVALUATION OF HISTORICAL RESEARCH IN THE DIGITAL AGE: SPANISH JOURNALS AND DATABASES}

\author{
LUIS RODRÍGUEZ YUNTA ${ }^{1}$ \\ CSIC, Centro de Ciencias Humanas y Sociales \\ luis.ryunta@cchs.csic.es
}

Recibido: $18 / 05 / 2016$

Aceptado: 29/08/2016

\begin{abstract}
RESUMEN: Se analiza la transformación operada con el desarrollo de Internet en el ecosistema formado por las revistas académicas y las bases de datos bibliográficas, con especial atención a la situación de las publicaciones españolas de Historia. Las bases de datos, en especial los índices de citas, permiten categorizar las revistas, pero actualmente los indicadores extraídos de la citación son inadecuados para valorar muchos ámbitos de Ciencias Humanas y Sociales. Se analiza en detalle la situación del área de Historia, sus características bibliométricas y la utilidad de las bases de datos bibliográficas para extraer indicadores alternativos y estadísticas para el análisis historiográfico, en el marco del desarrollo de las Humanidades digitales.
\end{abstract}

PALABRAS CLAVE: España; Revistas científicas; Revistas de Historia; Bases de datos; Edición electrónica; Humanidades digitales

\begin{abstract}
This article analyzes the transformation operated with the development of Internet in the ecosystem of academic journals and bibliographic databases, with particular attention to the situation of Spanish publications about History. Databases, especially citation indexes allow categorize journals, but currently citation indicators are inadequate to assess many areas of human and social sciences. The paper analyzes in depth the situation in the field of History, its bibliometric characteristics and usefulness of bibliographic databases to extract alternative indicators and statistics for the historiographical analysis in the context of the development of digital humanities.
\end{abstract}

${ }^{1}$ Declaración de intereses: el autor forma parte del equipo de trabajo en algunos de los productos que se citan en el texto, la base de datos ISOC y el sistema Latindex, y ha colaborado en algunos de los proyectos del Grupo EPUC. 
KEYWORDS: Spain; Academic journals; History; Databases; Electronic publishing; Digital humanities

\section{REVISTAS ACADÉMICAS Y BASES DE DATOS COMO MEDIOS PARA LA COMUNICACIÓN Y EVALUACIÓN DE LA CIENCIA EN LA ERA DIGITAL.}

La revista científica tiene actualmente una doble naturaleza, como vehículo de transmisión de ideas o resultados de la investigación, y como instrumento de valoración de la actividad científica. En ninguna disciplina científica la revista es el único medio de publicación que utilizan los investigadores para comunicar sus aportaciones al progreso científico. Y sin embargo, sí es frecuente que se constituya en un medio indispensable para la evaluación, influyendo en la promoción de los investigadores o en la concesión de proyectos. Este hecho se debe esencialmente a la utilización de las bases de datos documentales que han permitido disponer de fuentes para extraer estos datos estadísticos y establecer herramientas para determinar el valor de una publicación en comparación con otras de su misma disciplina.

La evolución de las bases de datos ha sido paralela a la implantación de la era digital. La generalización de Internet como medio para la edición ha dado un vuelco sustancial al mercado de la información científica tanto por parte de la edición de revistas científicas como para las propias bases de datos. Puede decirse que en este momento la comunicación científica se genera ya de forma predominante en formato digital. También en España y en las disciplinas de Ciencias Humanas y Sociales, la edición electrónica es ya la opción mayoritaria (Gráfico I).

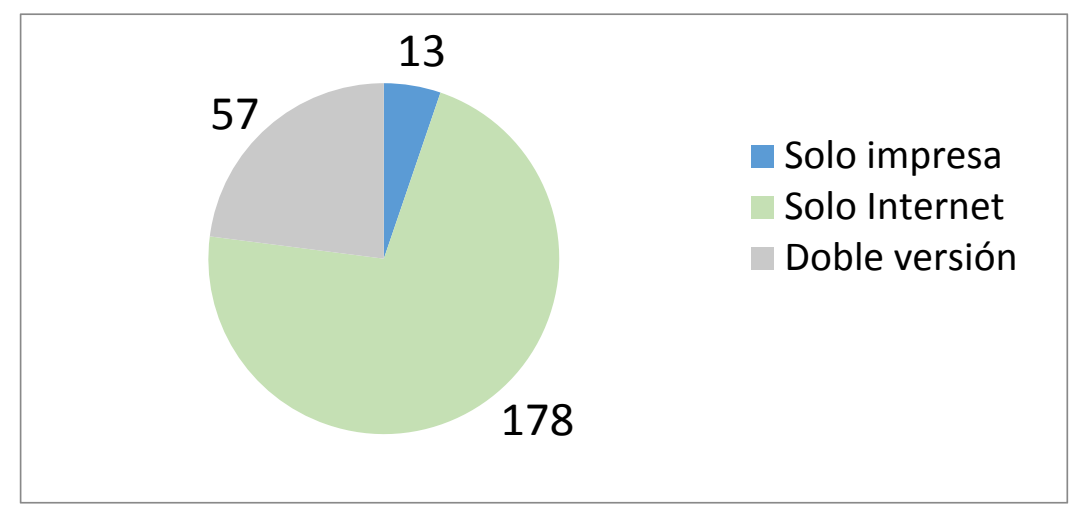

Gráfico I: Revistas de Ciencias Humanas y Sociales ingresadas en la base de datos ISOC, nacidas en el periodo 2010-2014. Elaboración propia, consulta 15/03/2016. 


\subsection{Transformación de la edición de revistas y de las bases de datos bibliográficas en la era de Internet}

La edición de revistas electrónicas directamente a través de Internet ha trastocado el mercado editorial de forma sustancial, especialmente en el medio académico. Entre estos cambios cabe destacar:

- El acceso es individual, inmediato y universal, con la única discriminación de los medios económicos del usuario o de su institución cuando la empresa editorial no asume la política de acceso abierto y exige un pago. Los lectores acceden desde su propia mesa de trabajo en vez de acudir a una biblioteca. Incluso cuando ésta opera como intermediaria para la suscripción a plataformas editoriales, el acceso puede hacerse cómodamente desde cualquier ubicación implementando sencillos sistemas de identificación de los usuarios con derecho al acceso. No hay tiempo de espera, el número editado está inmediatamente en línea sin los costosos envíos postales a suscriptores e instituciones con intercambio.

- Mayor visibilidad internacional: la distribución está globalizada y ya no se supedita a las diferencias en los costes de los envíos postales. Para las revistas en español esto supone superar la barrera de las distancias con los países de la Comunidad Iberoamericana. Las posibilidades de recepción e impacto se multiplican.

- Aceleración de los procesos de edición. Las revistas que deseen apostar por la difusión inmediata pueden ofrecer números en proceso, sin esperar a completar todos los artículos. O incluso pueden optar por sistemas de evaluación por pares que se establecen después de la publicación.

- Ampliación de los posibles contenidos. Los textos se enriquecen con relaciones a otros artículos, fuentes o ficheros de datos o contenidos multimedia.

- Las revistas reducen costes con mejores prestaciones. Asumen servicios que antes realizaban las bases de datos (búsquedas en números anteriores, suscripción de alertas) junto a nuevas herramientas (enlaces, foros, encuestas, estadísticas de uso). El formato digital permite además experimentar con nuevas formas de revisión por pares con una mayor transparencia.

- Si se producen conflictos éticos que se detectan después de haberse autorizado la publicación, las revistas pueden actuar eficazmente para corregir su decisión, procediendo a la retractación de los artículos implicados.

No todo es positivo, la situación actual presenta también algunos inconvenientes: 
- El mercado de la edición científica se ha concentrado en grandes editoriales. Solo los grandes grupos multinacionales o colecciones de revistas están en condiciones de obtener un rendimiento por la venta de suscripciones en Internet. El pequeño editor encuentra cada vez más dificultades para mantenerse en el circuito comercial y mucho más para obtener beneficios.

- Las bibliotecas pasan a segundo plano y pierden opciones de acopio de documentos mediante canje. Al quedar fuera de los fondos bibliotecarios se acrecienta la dificultad para el control bibliográfico de nuevas revistas. El abaratamiento de costes de edición directa en Internet fomenta la constante aparición de revistas y alimenta la dispersión de títulos. Crecen las colecciones de las multinacionales y también la oferta de instituciones que se sitúan al margen del mercado, difundiendo sus contenidos en acceso abierto.

- Se precisan políticas de preservación: las colecciones no se almacenan en las bibliotecas, se suprimen los intercambios. Es necesario prever que los formatos electrónicos pueden quedar obsoletos con la aparición de nuevas tecnologías

- La revista pierde en parte su naturaleza unitaria, debido a que el artículo se distribuye usualmente de forma independiente del resto del número. Si en el medio impreso este hecho podía darse a través de separatas, en Internet se convierte en lo habitual. Cada parte de la revista se define como un fichero independiente al que se accede directamente a través de buscadores o enlaces directos, sin pasar necesariamente por las páginas de portada o presentación, e ignorando otros contenidos que ofrecen las revistas como noticias, crónicas, reseñas, editoriales de opinión. Además los autores pueden depositar sus artículos en localizaciones ajenas a las del editor, de forma completamente autónoma.

Por su parte el mercado de la información también se ha transformado notablemente en las dos últimas décadas. Las bases de datos bibliográficas de artículos científicos, productos tradicionales imprescindibles en el siglo XX para la búsqueda de información bibliográfica, han pasado a ser tan solo una más de las muchas opciones existentes. Todavía perviven, aunque puedan ser desconocidas para muchos potenciales usuarios. Pueden ser bases especializadas en una disciplina (Medline, PsycInfo, Historical Abstracts, International Medieval Bibliography,...) o sistemas multidisciplinares que analizan la producción nacional o regional (bases de datos del CSIC en España, bases de datos de la UNAM para Latinoamérica). Se trata generalmente de bases de datos referenciales, es decir que contienen metadatos sobre las publicaciones, no sus textos. Sin embargo su evolución reciente incorpora enlaces 
al texto completo o puede relacionarse directamente con repositorios y hemerotecas digitales, en productos de carácter mixto como Dialnet.

Dentro de este conjunto sí han incrementado su posición los llamados índices de citas, un modelo peculiar de las bases de datos bibliográficas que apostó por incorporar masivamente las referencias citadas como medio para ampliar las posibilidades de localizar información bibliográfica. Se trata de un modelo representado tradicionalmente por Science Citation Index y sus productos paralelos, que actualmente forman Web of Science Core Collection de ISI Thomson Reuters. En los últimos años se ha añadido la competencia de Scopus (de la multinacional Elsevier) pero también la proliferación de información sobre citas en las bases de datos bibliográficas, plataformas editoriales, repositorios, buscadores, ...

Los índices de citas constituyen un negocio rentable por su influencia sobre los sistemas de evaluación de la ciencia. Sin embargo, para la búsqueda de información bibliográfica la oferta se ha diversificado, formando un ecosistema cada vez más complejo en el que actualmente conviven otros muchos productos de diferente naturaleza: catálogos de bibliotecas, herramientas de descubrimiento, plataformas editoriales comerciales a texto completo, portales de revistas en acceso abierto y documentación académica informal presente en repositorios, blogs, páginas personales, redes sociales,...

Y finalmente el recurso de mayor éxito es hoy en día el buscador Google. La dispersión de fuentes se aúna con la demanda de inmediatez en las respuestas, provocando que los usuarios desechen perder tiempo en analizar cada recurso, informarse de sus herramientas particulares y aprovechar sus potencialidades. El buscador Google y sus herramientas bibliográficas Google Books y Google Scholar, centralizan la atención de los usuarios. Google Scholar es hoy la fuente de documentos científicos más completa que da acceso a una cobertura cada vez mayor de contenidos. Frente a esta fuente universal intentan competir los recolectores de metadatos (Recolecta, Hispana, Europeana) o las Herramientas de descubrimiento instaladas en las bibliotecas, en donde los productos bibliográficos específicos quedan igualmente difuminados.

\subsection{Necesidad de la evaluación de revistas y dudas sobre la aplicación universal del análisis de citas}

Dada la transformación operada por la comunicación científica en el medio digital, cabe preguntarse si son necesarias las revistas científicas en la actualidad. En el medio 
impreso sólo la edición regular en revistas de amplia tirada y distribución internacional garantizaba una adecuada difusión, mientras que las publicaciones locales o la denominada literatura gris quedaban en un cierto anonimato. Por el contrario, cualquier investigador puede obtener hoy una accesibilidad universal a sus trabajos utilizando simplemente un blog, e igualmente se abren oportunidades para la autoedición o la difusión de contenidos no editados a través de repositorios. No obstante, la multiplicación de fuentes hace recomendable tener criterios de selección y para ello resulta relevante conocer si los documentos han pasado por un sistema de arbitraje.

En segundo lugar, y dado que siguen editándose revistas, cabe preguntarse si es necesario evaluar estas publicaciones, establecer parámetros de calidad o listas de categorías por disciplinas. El cumplimiento de parámetros formales, la difusión internacional o el impacto reflejado en citas no asegura la calidad científica de cada uno de sus artículos. Para valorar un artículo concreto, el prestigio de su autor y la relevancia e innovación de sus aportaciones deberían ser más importantes que el medio en que se publica. Y sin embargo, la producción científica es tan amplia que no es posible evaluar cada artículo de forma individual. Los parámetros que ofrece Internet como descargas o enlaces no son tampoco indicios claros de calidad. Es preciso por otra parte contar con herramientas para evaluar tanto al investigador novel como al ya consagrado. Si se carece de fuentes cuantitativas objetivas, se corre el riesgo de recurrir al juicio subjetivo de comités de expertos a los que a menudo se les pide valorar conjuntos amplios de disciplinas con líneas de investigación que desconocen.

La respuesta a ambas cuestiones no debe plantearse de modo independiente. La existencia de revistas de excelencia contrastada no es imprescindible pero sí recomendable tanto para la comunicación científica como para la evaluación de los currículos de los investigadores. Sin embargo, estas dos potencialidades sólo adquieren sentido si se puede construir un sistema objetivo y realmente representativo de categorización de las revistas.

Los índices de citas elaborados por ISI Thomson Reuters constituyen el punto de referencia más recurrente a nivel internacional para la evaluación de la producción científica. Su plataforma Web of Science abarca las tradicionales secciones de Science Citation Index, Social Science Citation Index y Arts \& Humanities Citation Index. Su principal competidor a nivel internacional es la base de datos Scopus producida por Elsevier, que aporta una cobertura mayor para los últimos años. El sistema de análisis de citas en ambas fuentes permite obtener rankings de revistas pero no es infalible, pues parte de dos premisas que no necesariamente se cumplen en todas las áreas del 
conocimiento: primera, que existe una corriente principal de la ciencia a nivel internacional, y segunda, que la selección de fuentes permite representar de forma independiente todas y cada una de las disciplinas y subdisciplinas existentes.

Cuando las comunidades científicas utilizan el inglés y trabajan sobre campos bien delimitados con un elevado número de investigadores, los resultados son más fiables que cuando se trata de sectores en los que la producción científica se dispersa en microcomunidades por el uso de diferentes idiomas, o la especialización en parcelas particulares del conocimiento o temas locales con pocos investigadores. Por ello, a nivel de grandes áreas del conocimiento, el modelo se adecúa mejor a las ciencias experimentales y encuentra más críticas en las Ciencias Sociales y Humanas, en donde el valor estadístico de los datos es muy limitado para la mayor parte de estas disciplinas: las revistas editan menor número de artículos y las citas se dispersan hacia otro tipo de fuentes con un intervalo temporal muy amplio. Incluso varían los patrones de citación de modo que una cita no indica necesariamente un reconocimiento a una obra anterior. A menudo las revistas se dirigen a comunidades nacionales o locales, no solo académicas y no predominantemente en inglés. Finalmente la coautoría no es tan frecuente como en las ciencias experimentales, lo cual también puede influir sobre la citación: un estudio sobre revistas de Historia económica muestra que la coautoría es un factor de éxito para recibir mayor número de $\operatorname{citas}^{2}$.

La aplicación de los índices de citas a las Ciencias Humanas y Sociales se ve perjudicada por todas estas circunstancias. Al estar menos definida una corriente central de revistas internacionales de impacto universal, el número de revistas fuentes es menor; como además estas publicaciones editan un número más reducido de artículos, los datos globales que pueden analizarse son claramente parciales. A menudo se ha cuestionado el factor de impacto, formulando indicadores alternativos ${ }^{3}$, pero ningún sistema de cálculo puede evitar las carencias en la toma de datos. La realidad es que la representación de las Ciencias Humanas y Sociales en los índices de citas es muy desequilibrada respecto al peso que tienen en la producción científica de los países de la Comunidad Iberoamericana. Las revistas recogidas en las tres secciones de Web

${ }^{2}$ G. DI VAIO, D. WALDENSTRÖM y J. WEISDORF (2012). “Citation success: Evidence from economic history journal publications". Explorations in Economic History, n. 49, pp. 92104.

3 R. ALEIXANDRE-BENAVENT, J.C. VALDERRAMA-ZURIÁN y G. GONZÁLEZALCAIDE (2007). "El factor de impacto de las revistas científicas: limitaciones e indicadores alternativos". El Profesional de la Información, vol. 16, n. 1, pp. 4-11. 
of Science muestran una clara diferencia con la distribución de las disciplinas en el directorio Latindex (Tabla I).

\begin{tabular}{|c|c|c|}
\hline Latindex & \multicolumn{2}{|c|}{ Web of Science } \\
\hline Revistas vigentes & Revistas & Artículos en 2014 \\
\hline $\begin{array}{l}\text { Artes y Humanidades } 3055 \\
(14 \%)\end{array}$ & $\begin{array}{l}\text { Arts \& Humanities } \\
\text { Citation Index: } 1769 \\
(13 \%)\end{array}$ & $\begin{array}{l}\text { Arts\&HumanitiesCitationIndex: } \\
120.906(6 \%)\end{array}$ \\
\hline CienciasSociales $10311(47 \%)$ & $\begin{array}{l}\text { Social Science } \\
\text { Citation Index: } 3230 \\
(23 \%)\end{array}$ & $\begin{array}{l}\text { Social ScienceCitationIndex: } \\
275.447(13 \%)\end{array}$ \\
\hline $\begin{array}{l}\text { Ciencias Exactas y Naturales } \\
\text { 2452, Ingeniería 1449, } \\
\text { Ciencias Médicas 3356, } \\
\text { Ciencias Agrícolas } 1247 \\
(39 \%)\end{array}$ & $\begin{array}{l}\text { Science Citation } \\
\text { Index Expanded: } \\
8827(64 \%)\end{array}$ & $\begin{array}{l}\text { Science Citation Index } \\
\text { Expanded: } 1.779 .302(82 \%)\end{array}$ \\
\hline
\end{tabular}

Tabla I. Comparación entre la distribución por disciplinas de las revistas registradas en Latindex respecto a las secciones de Web of Science. Elaboración propia, búsqueda realizada el 15/03/2016

En el caso de España y de los países iberoamericanos, durante el siglo XX la mayor parte de las publicaciones se mantenían en el medio impreso casi exclusivamente en un ámbito de difusión nacional y manejando presupuestos muy escasos, especialmente en Ciencias Sociales y Humanas. Internet ha facilitado su difusión universal pero en su mayor parte no alcanzan una buena posición en los indicadores de citación, o están ausentes de estos sistemas. Al no tener garantizada la valoración de los trabajos publicados, los autores desconfían, las revistas no reciben suficientes originales para seleccionar los mejores, se acumulan retrasos en la edición y se potencia que surjan nuevas iniciativas con escasa solidez.

Aunque Web of Science y Scopus, por efecto de su competencia, han incrementado el número de fuentes en diferentes idiomas, los autores tienden a realizar sus citas hacia el mismo idioma en el que escriben y además hacia el inglés, con lo que se incrementa el predominio de ésta lengua en la citación. Las revistas nacionales en Ciencias Humanas y Sociales quedan restringidas a circuitos locales con poca o nula repercusión internacional $1^{4}$.

${ }^{4}$ F. BEIGEL y M. SALATINO (2012). "Circuitos segmentados de consagración académica: las revistas de Ciencias Sociales y Humanas en la Argentina”. Información, cultura y sociedad, n. 32, pp. 11-35. 
Frente a las limitaciones de Web of Science y Scopus, varios proyectos en España desarrollaron índices nacionales que no han tenido continuidad, a partir de una selección de revistas en Medicina (IMEcitas), en Ciencias Humanas y Sociales (RESH en el CSIC, IN-RECS, IN-RECH e IN-RECJ en la Universidad de Granada) o incluso en la subdisciplina de Historia Moderna (Modernitas Citas en el CSIC). Otra opción para el análisis de citas se ha abierto con la aparición de Google Scholar Metrics, que permite una mayor universalización de la toma de datos sobre citas recibidas, dado que además de incorporar revistas españolas se suman las iberoamericanas que teóricamente podrían aportar mayores relaciones en las áreas de Ciencias Sociales y Humanidades. Si bien se carece por el momento de una edición estable y permanente de resultados de GSM, el grupo EC3 de la Universidad de Granada ha elaborado informes limitados a las revistas españolas desde el periodo 2007-2011 en adelante 5 .

\subsection{Alternativas a la categorización de revistas al margen de los índices de citas}

En las últimas décadas numerosos proyectos han explorado vías alternativas para la categorización de publicaciones, que Ángel Borrego y Cristóbal Urbano ${ }^{6}$ resumen en tres modelos: la evaluación por pares mediante encuestas, el análisis de características editoriales y la valoración de su difusión. Productos como RESH (CSIC) o ERCE (Universidad de Zaragoza) integraron varios de estos factores, pero no han pervivido.

El sistema Latindex es la iniciativa más duradera y estable en este grupo, aunque también tiene claras limitaciones. Surge a partir de 1996 con el objetivo de reforzar la calidad y potenciar la visibilidad de las revistas científicas en América Latina, Caribe, España y Portugal. Las revistas son evaluadas con una tabla consensuada de 33 características editoriales, 36 para las versiones electrónicas, que definen las buenas

${ }^{5}$ El grupo de investigación EC3 Evaluación de la Ciencia y la Comunicación Científica ha publicado diferentes informes sobre las revistas españolas según los datos de Google Scholar Metrics, pero igualmente ha subrayado las inconsistencias de esta fuente. Como ejemplos de estas dos facetas de su trabajo véase J.M. AYLLÓN MILLÁN, A. MARTÍN MARTÍN, E. ORDUÑA MALEA y E. DELGADO LÓPEZ-CÓZAR (2015). Índice $H$ de las revistas científicas españolas según Google ScholarMetrics (2010-2014). Granada: EC3. (EC3 Reports; 13); y E. DELGADO LÓPEZ-CÓZAR y A. CABEZAS-CLAVIJO (2012). "Google Scholar Metrics: an unreliable tool for assessing scientific journals". El Profesional de la Información, vol. 21, n. 4, pp. 419-427.

${ }^{6}$ Á. BORREGO y C. URBANO (2006). "La evaluación de revistas científicas en Ciencias Sociales y Humanidades”. Información, cultura y sociedad, 2006, n. 14, pp. 11-27. 
prácticas editoriales. Todas las publicaciones registradas forman parte del directorio Latindex, pasando a catálogo las que cumplen 25 criterios, como baremo establecido para distinguir las publicaciones que cumplen los parámetros de buenas prácticas en la edición científica. En su primera década de funcionamiento se multiplicó por seis el número de títulos registrados, pasando de 2.460 en 1997 a 16.690 en 2008, con un 19\% en el catálogo ${ }^{7}$. Actualmente alcanza ya $24.547^{8}$, con cinco países por encima de los 2000 registros: Brasil, España, Argentina, México y Chile. El número de títulos en catálogo es ya de 8.376 revistas (el 34\%). En el caso de España de 4.220 registros, hay 2.166 en catálogo $(51 \%)$.

Las características definidas en el sistema Latindex se basan sobre todo en características formales, poco discriminantes y fáciles de alcanzar para cualquier editor. Su puesta en marcha ha potenciado una mejora considerable en el cumplimiento de buenas prácticas (Tabla II), de modo que la tendencia conduce hacia una equiparación de los resultados en un número cada vez más numeroso de publicaciones que cumplen todos o casi todos sus parámetros.

\begin{tabular}{|l|c|c|c|}
\hline $\begin{array}{l}\text { Características } \\
\text { editoriales }\end{array}$ & $\begin{array}{c}\text { Cumplimiento } \\
\text { inicial 2000- } \\
\mathbf{2 0 0 3}\end{array}$ & $\begin{array}{c}\text { Cumplimiento de } \\
\text { las revistas en } \\
\text { Catálogo en 2015 }\end{array}$ & $\begin{array}{c}\text { Cumplimiento } \\
\text { en nuevas } \\
\text { revistas }\end{array}$ \\
\hline $\begin{array}{l}\text { Cumplimiento de la } \\
\text { periodicidad }\end{array}$ & $58,44 \%$ & $89,91 \%$ & $96,63 \%$ \\
\hline $\begin{array}{l}\text { Mención del sistema de } \\
\text { arbitraje }\end{array}$ & $35,13 \%$ & $86,03 \%$ & 90,55 \\
\hline $\begin{array}{l}\text { Mención de objetivos } \\
\text { científicos }\end{array}$ & $36,64 \%$ & $82,70 \%$ & 90,55 \\
\hline Evaluadores externos & $21,75 \%$ & $68,31 \%$ & $73,65 \%$ \\
\hline $\begin{array}{l}\text { Afiliación de los miembros } \\
\text { del consejo editorial }\end{array}$ & $23,64 \%$ & $72,15 \%$ & $92,57 \%$ \\
\hline Exigencia de originalidad & $41,04 \%$ & $80,80 \%$ & $94,41 \%$ \\
\hline Instrucciones a los autores & $52,09 \%$ & $90,75 \%$ & $94,60 \%$ \\
\hline
\end{tabular}

${ }^{7}$ A.M. FLORES, S. PENKOVA y A. ROMÁN ROMÁN (2009). "Once años de LATINDEX: una experiencia al servicio de las publicaciones científicas iberoamericanas”. Simbiosis, vol. 6, n. 1 .

${ }^{8}$ Búsqueda realizada el 25/03/2016. Para valorar estas cifras, debe tenerse en cuenta que las revistas con doble versión, impresa y electrónica, cuentan con doble registro en Latindex, de modo que no se corresponden exactamente con el número de publicaciones independientes. 


\begin{tabular}{|l|c|c|c|}
\hline $\begin{array}{l}\text { Membrete bibliográfico en } \\
\text { cada página (solo revistas } \\
\text { impresas) }\end{array}$ & $26,21 \%$ & $72,05 \%$ & $72,23 \%$ \\
\hline $\begin{array}{l}\text { Fechas de recepción y } \\
\text { aceptación de originales }\end{array}$ & $10,81 \%$ & $53,20 \%$ & $64,19 \%$ \\
\hline Resumen en un idioma & $52,70 \%$ & $91,35 \%$ & $98,65 \%$ \\
\hline Resumen en dos idiomas & $42,27 \%$ & $85,56 \%$ & $87,17 \%$ \\
\hline $\begin{array}{l}\text { Palabras clave en un } \\
\text { idioma }\end{array}$ & $33,63 \%$ & $88,31 \%$ & $97,98 \%$ \\
\hline $\begin{array}{l}\text { Palabras clave en dos } \\
\text { idiomas }\end{array}$ & $28,16 \%$ & $81,89 \%$ & $83,11 \%$ \\
\hline
\end{tabular}

Tabla II $^{9}$. Evolución del grado de cumplimiento por revistas españolas de algunas características editoriales de Latindex entre 2000 y 2015, así como en revistas aparecidas entre 2011 y 2013

Aunque la mejora ha sido notable, también ha podido causar la falsa impresión de que basta cumplir parámetros formales para alcanzar la excelencia. Actualmente la presencia en el catálogo solo puede interpretarse como un requisito de mínimos, no permite categorizar o establecer niveles de calidad utilizables en la valoración de los curricula de los investigadores.

La European Science Foundation puso en marcha en 2007 otra iniciativa para categorizar las publicaciones europeas de Ciencias Humanas y Sociales: European Reference Index for the Humanities (ERIH). La novedad de este sistema radicaba en el establecimiento de categorías en base al grado de internacionalidad de las revistas. Sin embargo, los resultados publicados mostraron la complejidad de esta medición y su falta de transparencia ${ }^{10}$. El sistema ha sido transferido a un nuevo servicio gestionado en Noruega y actualmente no ofrece información sobre diferentes categorías, aunque sí unos criterios de calidad para la selección de nuevos títulos. En España cabe reseñar también las convocatorias realizadas por la FECYT desde 2007 para otorgar un sello de calidad a las publicaciones que pasan su evaluación. La certificación de la FECYT exige aportar documentación para verificar el cumplimiento

\footnotetext{
${ }^{9}$ Tabla incluida en T. ABEJÓN PEÑA y L. RODRÍGUEZ YUNTA (2015). "La participación española en Latindex: valoración de resultados e impacto sobre la calidad y evaluación de las publicaciones científicas”. Ciência da Informação, vol. 44, n. 2., pp. 258-275.

${ }^{10}$ A. ROMÁN ROMÁN y E. GIMÉNEZ TOLEDO (2010). "Cómo valorar la internacionalidad de las revistas de Ciencias Humanas y su categorización en ERIH”. Revista Española de Documentación Científica, vol. 33, n. 3, pp. 341-377.
} 
de buenas prácticas, por lo que sus resultados ofrecen mayor rigurosidad y dificultad para los editores que las descripciones realizadas en Latindex.

Otro sistema de categorización de revistas es CARHUS Plus + de la agencia de evaluación AGAUR en Cataluña, que aprovecha el indicador ICDS (Índice Compuesto de Difusión Secundaria) del portal MIAR de la Universitat de Barcelona, basado en la presencia de las revistas en bases de datos bibliográficas, índices de citas, repertorios de evaluación y portales de sumarios. Igualmente el sistema CIRC, gestionado en su versión 2.0 por la spin-off EC3metrics, establece categorías a partir de la presencia en los índices de citas junto a otras fuentes como Latindex y ERIH. La presencia en bases de datos fue valorada también en el portal DICE (Difusión y Calidad Editorial de las Revistas Españolas de Humanidades y Ciencias Sociales y Jurídicas) elaborado por el grupo EPUC del CSIC hasta 2010.

Se presupone que la difusión de una revista es un indicio de su calidad, aceptando que el mayor peso debe corresponder a los títulos seleccionados en Web of Science y Scopus y completando sus datos con fuentes nacionales y sistemas internacionales. Sin embargo, a través de estos sistemas no resulta posible distinguir si la selección realizada por ISI Thomson Reuters y Elsevier es la adecuada.

\section{LAS REVISTAS DE HISTORIA EN EL MARCO DIGITAL ESPAÑOL}

\subsection{Dimensión y crecimiento de las publicaciones de Historia en España}

La disponibilidad casi universal de Internet facilita la recopilación de datos sobre publicaciones de cualquier especialidad de la Historia ${ }^{11}$. No obstante, se trata de un universo en continua transformación, los títulos pueden desaparecer, cambiar de ubicación o sufrir demoras en la publicación. Los investigadores precisan de recursos para valorar las publicaciones de mayor estabilidad y prestigio, a fin de buscar las mayores garantías para el reconocimiento a la publicación de sus trabajos. Como en otras disciplinas la cultura de la calidad se ha impuesto en el ámbito de las publicaciones españolas de Historia. Los títulos que alcanzan cierto reconocimiento reciben también una sobredemanda de artículos para publicar, incrementándose la necesidad de esfuerzo de los editores sin obtener paralelamente mayores ayudas para

11 I. BLANCO FAURA (2009) "Revistas electrónicas de Historia de América en red". Naveg@merica. Revista electrónica de la Asociación Española de Americanistas, n. 2. 
la edición ${ }^{12}$.

La base de datos ISOC, elaborada por el CSIC, reúne información bibliográfica sobre las revistas científicas españolas de Ciencias Humanas y Sociales, editadas desde 1975, constituyendo una fuente de información idónea para los estudios bibliométricos sobre la producción científica editada en España ${ }^{13}$. El directorio de revistas incluidas en esta base de datos es un recurso apropiado para analizar las revistas académicas españolas de Historia. En marzo de 2016 figuran 1518 publicaciones vigentes de Ciencias Humanas y Sociales seleccionadas para el vaciado en la base de datos, es decir, que cumplen requisitos mínimos de calidad y no son de carácter divulgativo. Dentro de este conjunto la Historia está representada por 188 títulos $(12 \%)^{14}$, solo superado por Filología y Ciencias Jurídicas, y muy similar al de Ciencias de la Educación (Véase Gráfico II). Si se le añade Arqueología y gran parte de las Interdisicplinares, se convierte en el área de mayor peso dentro de la edición en Ciencias Humanas y Sociales.

${ }^{12}$ M.I. DEL VAL VALDIVIESO (2014). "La evaluación de las publicaciones científicas en España: las revistas de Historia”. Mélanges de la Casa de Velázquez, vol. 44, n. 2, pp. 307-311. ${ }_{13}$ Para una descripción más detallada de la base ISOC véase T. ABEJÓN PEÑA, A. MALDONADO MARTÍNEZ, L. RODRÍGUEZ YUNTA y M.C. RUBIO LINIERS (2009). "La base de datos ISOC como sistema de información y fuente para el análisis de las ciencias humanas y sociales en España”. El Profesional de la Información, vol. 18, n. 5, pp. 521-528.

${ }^{14}$ En el directorio de revistas de la base de datos ISOC se recogen todas las publicaciones que en algún momento han servido de fuente para este producto. Algunas de éstas pueden ser títulos ya no editados y en otros casos revistas que no cumplen los actuales requisitos de selección. Del total de 231 registros clasificados como de Historia, solamente 188 son revistas vigentes y seleccionadas para el vaciado en la base de datos ISOC. 


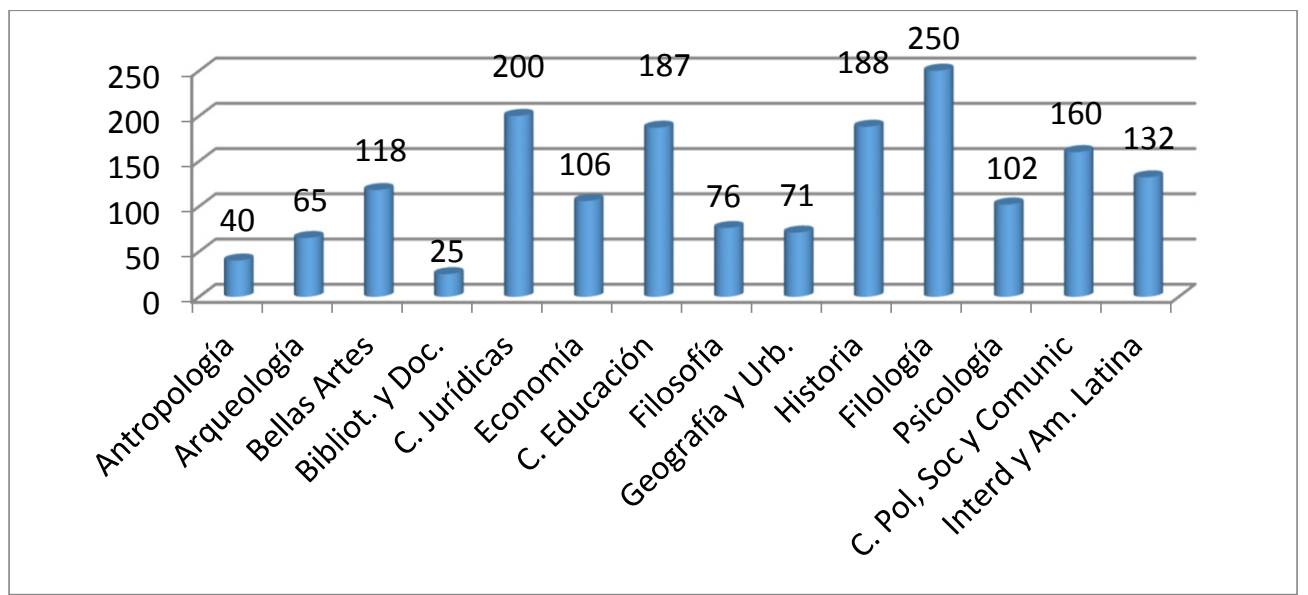

Gráfico II. Distribución por disciplinas de las revistas vigentes seleccionadas para el análisis en la base de datos ISOC. Elaboración propia, búsqueda realizada el 28/03/2016.

En la aparición de nuevas revistas ingresadas en la base de datos ISOC y nacidas a partir de 2010, la Historia representa un porcentaje algo menor: 25 nuevos títulos sobre $248(10 \%)^{15}$. Por encima se encuentran algunas disciplinas como Filología (48), Ciencias Políticas, Sociología y Comunicación (47), Educación (29), Interdisciplinares y Estudios Latinoamericanos (29), Bellas Artes (28) y Ciencias Jurídicas (26). Por debajo quedan Ciencias económicas (18), Psicología (14), Filosofía (10), Geografía y Urbanismo (9), Arqueología (7), Antropología (5) o Biblioteconomía y Documentación (4).

A partir de los datos de Latindex puede considerarse que el peso de la Historia en la edición científica es mayor en España que en los demás países iberoamericanos. En este sistema existen 4220 registros de publicaciones españolas, de los que 347 (8\%) se clasifican en Historia ${ }^{16}$, por encima del 7\% en Argentina y del 4\% en Brasil, Chile o México (Véase Gráfico III).

\footnotetext{
${ }^{15}$ El surgimiento de nuevos títulos es habitualmente mayor en disciplinas emergentes o poco consolidadas. Al ser relativamente baja en el área de Historia puede interpretarse que es un área consolidada y que se refleja una cierta saturación que no anima a iniciar nuevos proyectos editoriales.

${ }^{16}$ La cifra es mayor que la de la base ISOC porque en este caso se cuentan revistas que han dejado de publicarse junto a otras de carácter divulgativo, y debe tenerse en cuenta que en Latindex las revistas con doble versión, Impresa y electrónica, generan dos registros, mientras en la base de Datos ISOC solamente uno.
} 


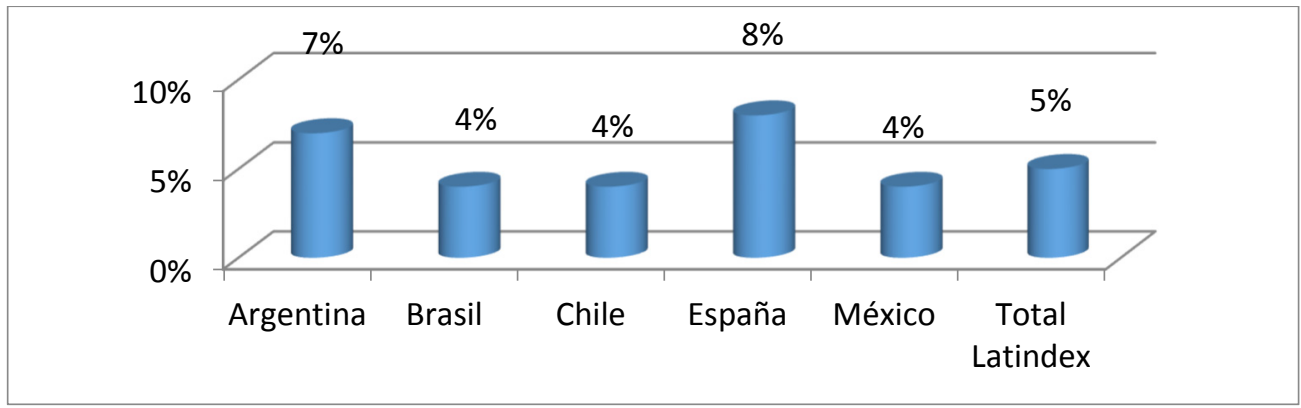

Gráfico III. Porcentaje de revistas de Historia registradas en Latindex sobre el total de publicaciones de cada país, comparativa entre los países de mayor producción editorial. Elaboración propia, búsqueda realizada el 28/03/2016.

Analizando la evolución temporal en el número de publicaciones editadas (Gráfico IV) se observa que la tendencia general es el crecimiento constante en el número de revistas académicas editadas en España. Si bien algunas publicaciones quedan abandonadas, en la mayor parte de los años es mayor el incremento de nuevos títulos.

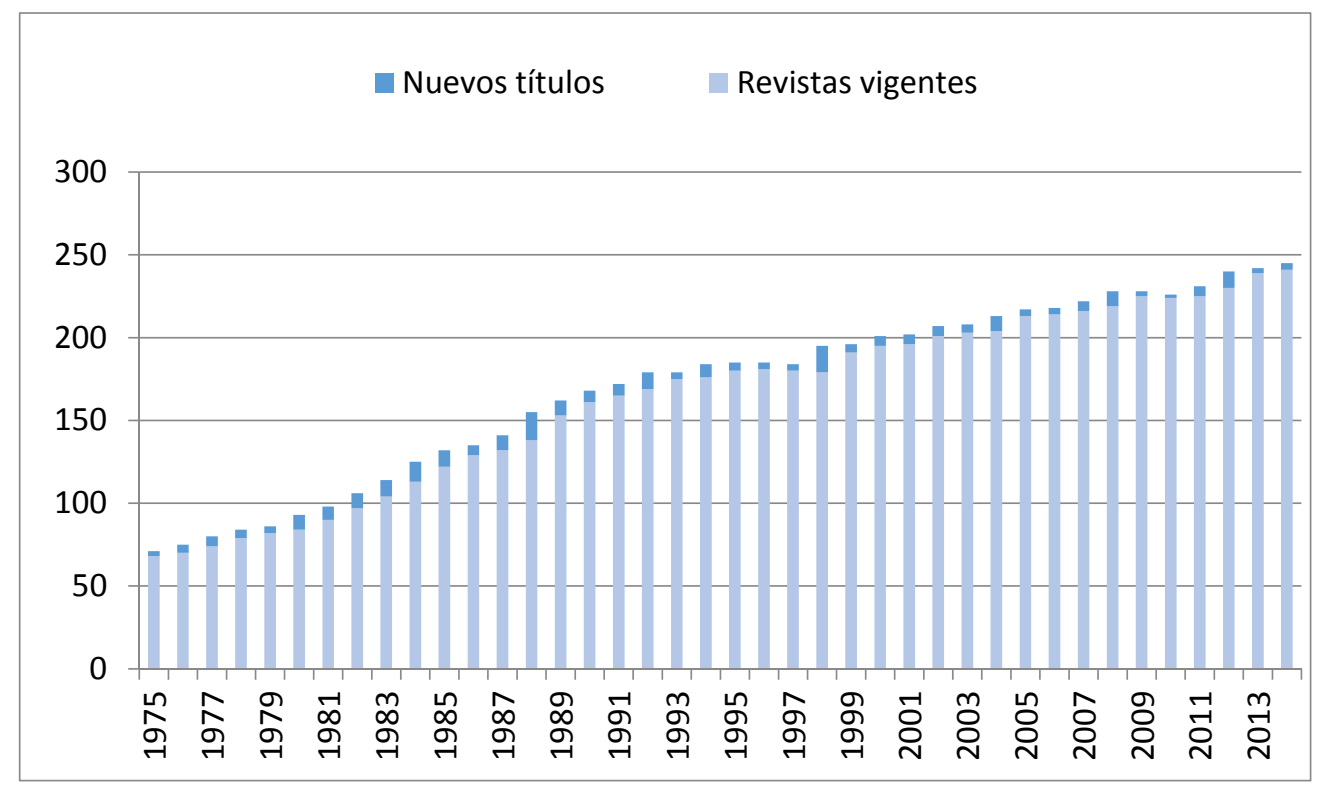

Gráfico IV. Evolución del número de revistas vigentes de Historia registradas en la base de datos ISOC desde el origen de la toma de datos en 1975. Elaboración propia, búsqueda realizada el 28/03/2016. 
En conclusión, la dispersión de revistas es elevada y creciente. Las causas son diversas:

- Al igual que en todas las áreas junto a publicaciones de amplia cobertura se crean también nuevos títulos para representar subdisciplinas y microdisciplinas, pero a ello se añaden en la Historia las especializaciones por ámbitos geográficos y áreas culturales particulares.

- Las instituciones dedicadas a la investigación histórica buscan la presencia social y el prestigio. La edición es tradicionalmente una de sus actividades principales.

- Actualmente, hay grandes facilidades para editar publicaciones con un escaso presupuesto, aunque en su mayor parte son proyectos pequeños con igualmente un escaso número de artículos.

La oferta de revistas de investigación histórica se complementa con una fuerte presencia en publicaciones de estudios locales con una extensa producción en España ${ }^{17}$ (Rubio, 2005). Se trata generalmente de estudios de menor nivel, pero también es cierto que "minusvalorar o considerar menos internacionales los estudios sobre ámbitos muy concretos, - no es lo mismo local que localista -, es una tendencia que no puede aplicarse a la investigación histórica, magnífica y profusamente representada por estudios concretos fundamentales para el avance de las Ciencias Históricas"18.

\subsection{Posición de las revistas de Historia en los sistemas de evaluación}

Los índices de citas de Web of Science Core Collection recogen en la actualidad 17 publicaciones de las 231 revistas que están clasificadas como de Historia en la base de datos ISOC. Supone por tanto solamente un 7\%. Sin embargo, la situación ha mejorado notablemente en los últimos años, pues 14 de estos títulos han sido incorporadas a partir de 2007. Antes de esa fecha solamente se incorporaban 3 revistas españolas de Historia: Dynamis (desde 1981), Hispania (desde 1975) y Revista de Indias (desde 1976).

El ranking tradicional elaborado por este producto se establece a partir del factor de impacto publicado anualmente en el Journal Citation Report (JCR), si bien el

17 M.C. RUBIO LINIERS (2005). "Evaluación y normalización de las revistas científicas españolas de Historia local". En: VII Encuentro de Primavera sobre Contenidos, edición y difusión de las revistas científicas de historia local, El Puerto de Santa María (Cádiz).

18 A. MALALANA UREÑA, A. ROMÁN ROMÁN y M.C. RUBIO LINIERS (2007). "Visibilidad internacional de las revistas españolas de historia". Scripta Nova, vol. 11, n. 234. 
sistema ofrece también otros indicadores. Para el caso de la Historia, este producto tiene tres claros inconvenientes:

a) El factor de impacto tradicional solo tiene en cuenta un recorrido de dos años, una práctica poco adaptada para disciplinas como la Historia con una alta dispersión de las citas y una escasa obsolescencia de las publicaciones. Así de las 355 citas recibidas en $2014^{19}$ por las revistas españolas de Historia a partir de las publicaciones seleccionadas por ISI Thomson Reuters, solamente 56 citas se dirigen hacia los artículos de los dos años anteriores utilizados para el cálculo de este indicador. Por tanto, el $84 \%$ son citas perdidas, quedan fuera del criterio empleado.

b) El JCR excluye las publicaciones de la base Arts \& Humanities Citation Index. Las categoría History se encuentra tanto en esta sección como en Social Science Citation Index, si bien con un número de revistas considerablemente menor (86 frente a 288 títulos del mismo apartado en Humanidades). Lo mismo ocurre para la categoría History \& Philosophy of Science (con 60 en ciencias y 45 en ciencias sociales, frente a 65 en Humanidades). Por tanto, solo algunas de las revistas de Historia seleccionadas por ISI Thomson Reuters están presentes en sus rankings y se hace difícil la comparación con las que no lo están por haber sido relegadas al ámbito de Humanidades.

c) El área de Historia no forma un conjunto homogéneo, sino un abanico de diferentes microcomunidades diferenciadas por modelos de investigación, facetas temáticas, periodos, culturas, espacios regionales y enfoques locales. Puede dudarse de que exista una corriente principal de la ciencia en idioma inglés. Así, incluso las publicaciones que acumulan más citas se sitúan en cifras muy por debajo de la media de las ciencias experimentales, y las posibilidades de obtener una posición de prestigio se reducen notablemente cuando una revista publica en otros idiomas y está escasamente acompañada de publicaciones afines temáticamente en la selección de fuentes de Thomson Reuters.

Como consecuencia, de las 17 publicaciones españolas de Historia solamente 6 obtienen datos de factor de impacto publicado en JCR, con resultados muy discretos. Destaca Historia Agraria con 0,3 en 2014, única revista situada en el segundo cuartil del área de Historia. Su factor de impacto es superado por Dynamis con 0,306, que sin embargo queda en el cuarto cuartil de su categoría, Historia de la Filosofía y de la Ciencia. Por debajo de éstas quedan Revista de Historia Industrial $(0,290)$, Revista de Historia Económica $(0,259)$, Ayer $(0,197)$ e Historia y Política $(0,023)$. Las otras 11

${ }^{19}$ Búsqueda realizada en Web of Science el 15/03/2016 
publicaciones españolas del área no presentes en JCR obtienen igualmente un factor de impacto muy bajo cuando se realiza el cálculo a partir de búsquedas directas en Web of Science ${ }^{20}$ : Anuario de Estudios Americanos $(0,093)$, Revista de Indias $(0,075)$, Hispania $(0,064)$, Anuario de Estudios Medievales $(0,055)$, Melanges de la Casa de Velázquez $(0,054)$, Hispania Sacra $(0,039)$, Anuario de Historia de la Iglesia $(0,030)$, Asclepio (0,021), Historia y Comunicación Social $(0,017)$, Gladius (0) e Imago Temporis (0).

Además de Web of Science, deben tenerse en cuenta los indicadores bibliométricos extraídos de la base de datos Scopus de Elsevier. Aunque la selección de revistas españolas de Historia es más amplia en este producto, la cobertura es a menudo irregular y los resultados de citas recibidas son igualmente muy limitados. Scopus recoge datos de 31 revistas consideradas de Historia en la base ISOC, si bien solamente 25 aparecen bajo la categoría History ${ }^{21}$. De ellas las mejor situadas son Investigaciones de Historia Económica y Revista de Historia Económica, ambas en el primer cuartil de acuerdo con la valoración del Scimago Journal Rank.

Teóricamente los indicadores extraídos a partir de Scopus deberían corregir algunas de las limitaciones apuntadas para Web of Science, ya que incluyen una selección más amplia de fuentes españolas y analizan un periodo temporal algo más amplio (3 años en el Scimago Journal Rank). Sin embargo, los resultados continúan siendo insuficientes para extraer conclusiones claras. En disciplinas de Ciencias Sociales y Humanas como la Historia, las citas se distribuyen de forma muy dispersa de modo que los datos no permiten discriminar realmente para establecer un ranking claro.

En los informes elaborados a partir de Google Scholar Metrics el área de Historia figura junto a las revistas de Arqueología, y muestra también una gran dispersión en sus resultados, con un elevado número de títulos igualmente con un bajo nivel de citas recibidas. De acuerdo a los datos de 2010-201422, la revista mejor situada en el área de Historia (excluyendo las de arqueología) es Investigaciones de Historia Económica con un índice $\mathrm{H}$ de 7 . Se trata de un resultado muy corto en comparación con la primera posición de las revistas españolas en disciplinas como Ciencias de la Salud y

\footnotetext{
${ }^{20}$ Idem, búsqueda realizada en Web of Science el 15/03/2016. El cálculo se ha realizado dividiendo el número de citas recibidas en 2014 por el número de documentos de 2012 y 2013 considerados como artículos en dichas revistas dentro de la base de datos.

${ }^{21}$ Algunas publicaciones de Historia aparecen en epígrafes como Historia y Filosofía de la Ciencia (al igual que en Web of Science) o en otros como Estudios Culturales o Misceláneas. ${ }^{22}$ Publicados en AYLLÓN, MARTÍN, ORDUÑA y DELGADO (2015) op. cit.
} 
Biológicas (índice H 39) Psicología (34), Ciencias de la Tierra (24), Educación (23), Comunicación (22), Documentación (21), Matemáticas (18), Ciencias Agrarias (17), Ciencias del Deporte (17), Ingenierías (17), Economía (13), Lingüística (13), Derecho (12), Sociología (12), Antropología (11), Ciencias Políticas (11) o Geografía (10). En definitiva, la aportación de Google Scholar Metrics no resulta tampoco adecuada para analizar las revistas de Historia, no existe un núcleo de revistas destacadas, las citas se dispersan entre publicaciones representativas de comunidades parciales o en otro tipo de documentos.

En los productos elaborados a partir de citas nacionales, la disciplina de Historia obtuvo unos resultados igualmente discretos. Un estudio pionero en este sentido realizado sobre revistas españolas de Historia de los años 1997-9823, mostraba que el $74 \%$ de las citas se dirigían a monografías y el 56\% de las revistas citadas recibieron una única mención. Además la antigüedad media de las referencias era de 14 años. Cifras similares se obtuvieron en el proyecto Modernitas Citas con datos de 2000-0124. Estos hábitos de citación, unido al tiempo de espera entre el envío de un artículo y su publicación, provocan que el análisis de citas limitado a las revistas de los últimos años sea necesariamente muy poco representativo de las citas reales emitidas.

En el portal RESH, el valor medio de impacto del área de Historia fue de solo 0,076 en el periodo $1999-2003^{25}$. Si bien este dato quedaba por encima de la mayor parte de disciplinas humanísticas y sociales excepto Derecho y Psicología, puede decirse que el recurso a índices nacionales resultaba insuficiente para establecer un ranking de revistas en estas áreas, y de hecho en este portal se combinaba este análisis junto a la valoración por pares mediante encuestas y otros factores como el cumplimiento de criterios Latindex, la antigüedad y la presencia en bases de datos.

Tampoco puede establecerse que sea un indicio claro de calidad la selección de

${ }^{23}$ E. SANZ, F. CASTRO, E. POVEDANO et al. (2002). "Creación de un índice de citas de revistas españolas de Humanidades para el estudio de la actividad investigadora de los científicos de estas disciplinas". Revista Española de Documentación Científica, vol. 25, n. 4, pp. 443-454.

${ }^{24}$ F. FERNÁNDEZ IZQUIERDO, J. OSCA LLUCH, M. LÓPEZ, J. SENDRA ROIG, y M.C. RUBIO LINIERS (2010). "Problemas planteados en la creación de índices de citas en el área de Humanidades: la base de datos Modernitas Citas y las publicaciones de Historia Moderna". Revista Española de Documentación Científica, vol 33, n. 3, pp. 498-505.

${ }^{25}$ Dato extraído de M.D. ALCAIN PARTEARROYO, A. ROMÁN ROMÁN y E. GIMÉNEZ TOLEDO (2008). "Categorización de las revistas españolas de Ciencias Sociales y Humanas en RESH”. Revista Española de Documentación Científica, vol. 31, n. 1, pp. 85-95. 
títulos españoles de Historia moderna y contemporánea que realiza la principal base de datos internacional en este ámbito, Historical Abstracts ${ }^{26}$. Este producto está actualmente integrado dentro de los servicios de la multinacional Ebsco, su política de cobertura no es independiente, se relaciona con los acuerdos que establezca la compañía con editores. Igualmente para la Historia medieval, la base International Medieval Bibliography se ha integrado en la política de la empresa Brepols. Otros productos bibliográficos, como Regesta Imperii o L'Année Philologique, sólo resultan de interés para ámbitos muy específicos, al igual que las revistas de Historia económica, del derecho, de la religión, pueden aleatoriamente quedar cubiertas por productos específicos de estas disciplinas.

Algunos estudios se han centrado en analizar de forma específica la internacionalidad de las publicaciones, incluso de forma específica para las revistas de Historia $^{27}$. De estos trabajos se desprende que la visibilidad internacional depende a menudo del prestigio de la entidad editora, de la especialidad temática y de la política editorial. Pese a la preocupación por internacionalizarse, se constata que hasta el momento las revistas españolas no están logrando atraer suficientes colaboraciones internacionales. Temas clave de Historia de España como Al-Andalus, la conquista de América, la guerra civil o el franquismo, "tienen abundante bibliografía internacional, pero no en revistas españolas" 28 . En estas circunstancias, recurrir a la internacionalización de las publicaciones no aporta un criterio suficiente para discriminar la calidad de las revistas españolas.

\subsection{Cumplimiento de características editoriales de las revistas españolas de Historia}

La toma de datos inicial de la aportación española al sistema Latindex por parte del CINDOC entre 1998 y 2002 supuso la valoración de 1.278 revistas, de las que 136

\footnotetext{
26 F. MIKELARENA PEÑA (2007). "Parámetros de calidad de las revistas científicas españolas sobre historia moderna y contemporánea". Huarte de San Juan. Geografía e Historia, n. 14, pp. 297-312.

${ }^{27}$ MALALANA, ROMÁN y RUBIO, op. cit.. A. MALALANA UREÑA (2007). "Visibilidad internacional de las Revistas Españolas de Historia Moderna". Cuadernos de Historia Moderna, vol. 32, pp. 159-193. A. MALALANA UREÑA (2007). "Visibilidad internacional de las revistas españolas de historia medieval". En la España Medieval, vol. 30, pp. 455-496. A. MALALANA UREÑA (2007). "Visibilidad internacional de las revistas españolas de historia contemporánea". Studia Histórica. Historia Contemporánea, n. 25, pp. 445-485.

${ }^{28}$ MALALANA, ROMÁN y RUBIO, op. cit.
} 
(11\%) eran de Historia En el análisis de los resultados publicado por Román, Vázquez y Urdín ${ }^{29}$, esta disciplina obtuvo unos resultados muy discretos en gran parte de las características editoriales recomendadas con porcentajes de cumplimiento por debajo del $50 \%$ en 10 parámetros: presencia de resumen (33\%), resumen en dos idiomas (31\%), exigencia de originalidad (28\%), mención del sistema de arbitraje (19\%), membrete bibliográfico en cada página (19\%), afiliación de los miembros del comité de redacción (17\%), presencia de palabras clave (14\%), palabras clave en dos idiomas (13\%), evaluadores externos (12\%) e inclusión de fechas de recepción y aceptación de los textos (4\%). Hoy en día, todas estas características son en su mayoría de cumplimiento generalizado, especialmente en los nuevos títulos.

Latindex y las agencias de evaluación han potenciado una clara difusión en las buenas prácticas de la edición científica en las revistas españolas de Historia. De las 136 publicaciones de esta disciplina analizadas en 2002, ingresaron al Catálogo solamente $18(13 \%)$. Actualmente ${ }^{30}$ se registran 347 revistas españolas de Historia en el directorio de Latindex, y 200 en el catálogo (58\%). De las 22 más recientes, nacidas entre 2012 y 2014, lo están 17 (78\%). En estas recientes incorporaciones no hay ningún parámetro incumplido por más de la mitad de las publicaciones y los problemas más frecuentes radican en la mención de bases de datos que las recogen (difícil para nuevos títulos) y en la incorporación de aspectos técnicos de la edición electrónica (metaetiquetas dublin core y servicios de valor añadido), poco frecuentes en nuevas revistas que no utilizan el software OJS pero resuelto en las que sí lo emplean, utilidad cada vez más frecuente.

La valoración realizada en la base de datos ISOC a partir de los resultados obtenidos en Latindex en 2002 permitió rechazar un 12\% de los títulos vigentes registrados en el directorio de este producto ${ }^{31}$. En el área de Historia el porcentaje de rechazo fue más elevado que la media, llegando al $28 \%$ y estableciendo un total de 98 títulos seleccionados para esta disciplina. No obstante, desde este año muchas revistas rechazadas pudieron mejorar y surgieron nuevos títulos que ya se adaptaban a los requerimientos establecidos, de modo que actualmente suponen 188 los títulos seleccionados.

\footnotetext{
${ }^{29}$ A. ROMÁN ROMÁN, M. VÁZQUEZ VALERO, M. y C. URDÍN CAMINO (2002). "Los criterios de calidad editorial Latindex en el marco de la evaluación de las revistas españolas de Humanidades y Ciencias Sociales”. Revista Española de Documentación Científica, vol. 25, n. 3, pp. 286-303.

${ }^{30}$ Búsqueda realizada el 25/03/2016.

${ }^{31}$ ROMÁN, VÁZQUEZ y URDÍN, op. cit.
} 
A fin de cuentas, la creación de Latindex, como en su día de las bases de datos bibliográficas de la UNAM y del CSIC, respondió sobre todo a la intención de aumentar la visibilidad y difusión de las revistas ${ }^{32}$. Este objetivo se ha cumplido y el sistema resulta útil para el control de la producción científica en los países de la Comunidad Iberoamericana, si bien resulta insuficiente para categorizar su calidad.

El sello de calidad de la FECYT es notablemente más selectivo. Solamente 27 publicaciones de Historia estaban en posesión de este certificado en 2015. Sin embargo, estos 27 títulos representan el 14\% de las 192 publicaciones que lo obtuvieron en el total de las disciplinas, un porcentaje destacado. Estas revistas son: Anuario de Estudios Americanos; Anuario de Estudios Medievales; Asclepio; Ayer; Cuadernos de Historia Contemporánea; Cuadernos de Historia Moderna; Edad Media; Espacio, Tiempo y Forma, Historia Medieval; Gladius; Hispania; Historia Agraria; Historia Constitucional; Historia Contemporánea; Historia del Presente; Historia Social; Investigaciones de Historia Económica; Investigaciones Históricas; Llull; Medievalismo; Melanges de la Casa de Velázquez; Revista Complutense de Historia de América; Revista de Historia Económica; Revista de Historia Industrial; Revista de Historiografía; Revista de Indias; Studia Histórica. Historia Medieval y Studia Histórica. Historia Moderna.

\subsection{Características bibliométricas de las revistas españolas de Historia}

La base de datos ISOC permite obtener una visión de conjunto del panorama editorial de las revistas españolas. En este producto se recogen 126.921 registros de documento de Historia ${ }^{33}$, un 16,5\% del total de Ciencias Humanas y Sociales.

En la disciplina de Historia domina con claridad la autoría única de los artículos. De los 126.921 registros, solamente tienen coautoría 10.294 (8\%). Este dato es muy inferior al común en otras áreas en las bases de datos del CSIC: $80 \%$ en Biomedicina, $64 \%$ en Ciencia y Tecnología, 58\% en Psicología, 38\% en Geografía, 37\% en Arqueología, 35\% en Documentación, 34\% en Ciencias de la Educación, 28\% en Economía o 22\% en Sociología. Un porcentaje similar del 8\% se da en Bellas Artes y Ciencias Jurídicas, quedando por debajo solamente en Filosofía (4\%) y Literatura $(3 \%)$.

32 J.O. ALONSO GAMBOA (2000). "Iniciativas para aumentar la visibilidad de las revistas latinoamericanas: la aportación de CLASE, PERIÓDICA y LATINDEX”. En: Las revistas cientificas latinoamericanas: su difusión y acceso a través de bases de datos, $8^{a}$ Reunión sobre Revistas Académicas y de Investigación. México: UNAM, pp. 62-72.

${ }^{33}$ Búsqueda realizada el 28/03/2016 
De las 231 revistas vigentes ${ }^{34}$ clasificadas en el área de Historia en el directorio de la base de datos, pueden analizarse diferentes características:

a) Una distribución equilibrada por su antigüedad. El 34\% son publicaciones creadas ya en el siglo XXI, manteniéndose un ritmo bastante regular de aparición de nuevos títulos.

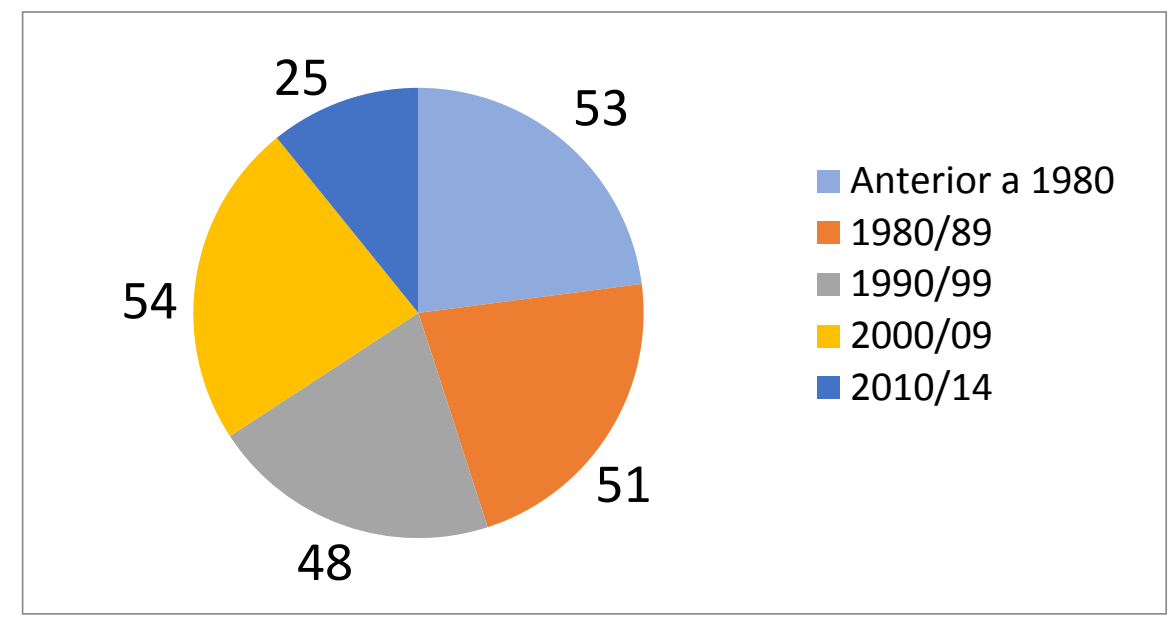

Gráfico V: Revistas vigentes de Historia en la base de datos ISOC, por fecha de aparición. Elaboración propia, consulta 15/03/2016.

b) Un $29 \%$ de las publicaciones reflejan la multidisciplinariedad en sus objetivos, quedando clasificadas junto a otras disciplinas: Estudios Latinoamericanos 13, Arqueología 8, Ciencias de la Educación 8, Ciencias Jurídicas 8, Geografía 8, Bellas Artes 7, Lingüística 6, Literatura 3, Economía 3, Sociología 3, Filosofía 2, Antropología 2, Ciencias Políticas 2, Interdisciplinares 2, Biblioteconomía y Documentación 1. Aparecen clasificadas solamente como Historia otros 164 títulos.

${ }^{34}$ Búsqueda realizada en la base de datos ISOC el 18/03/2016. Se excluyen del análisis tres publicaciones no españolas que se recogen en este directorio: Bulletin d'Histoire Contemporaine de l'Espagne, Cuadernos de Historia de España y Spagna Contemporanea. 
c) Por periodicidad, predominan con un $57 \%$ las publicaciones anuales. Se trata de una característica mostrada igualmente por los estudios publicados para las revistas españolas de ciencias sociales y humanidades en general ${ }^{35}$.

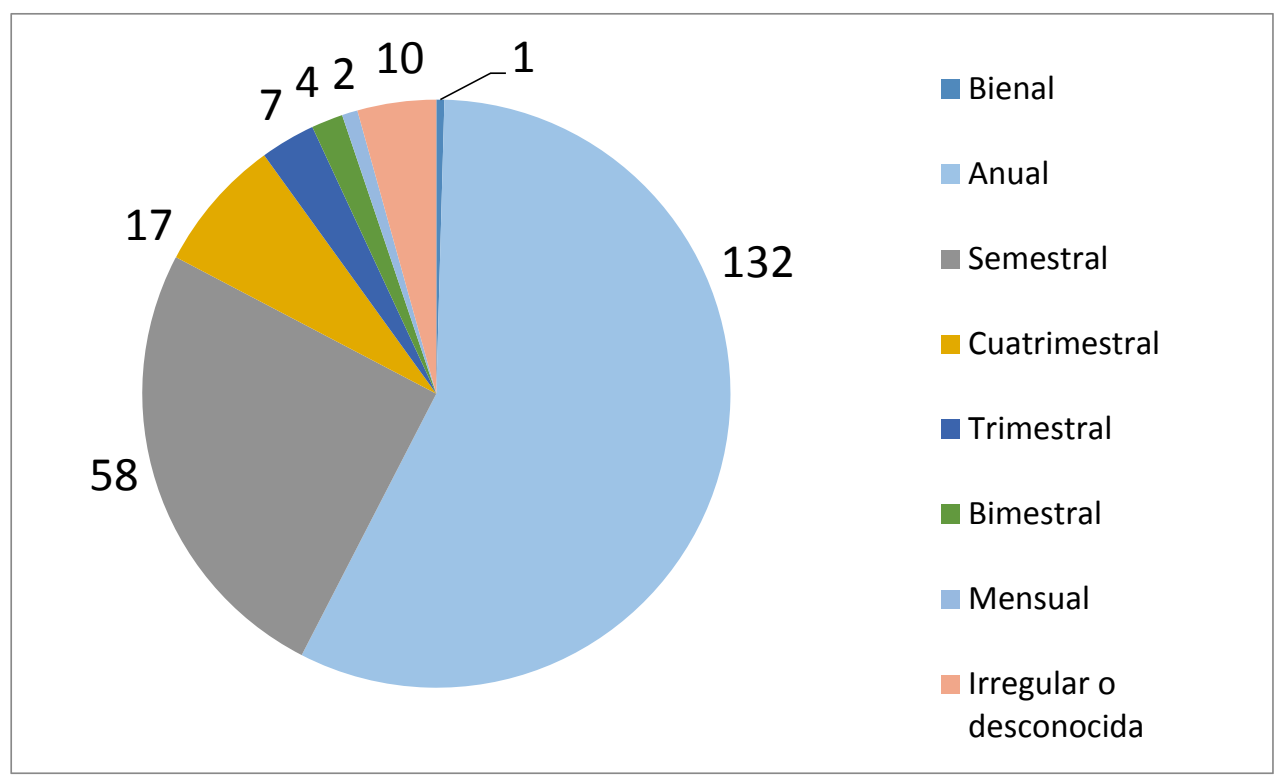

Gráfico VI: Revistas vigentes de Historia en la base de datos ISOC, por periodicidad. Elaboración propia, consulta 15/03/2016.

${ }^{35}$ J. OSCA LLUCH, M.E. MATEO MARQUINA (2003). "Difusión de las revistas españolas de ciencias sociales y humanidades. Acercamiento bibliométrico". Revista General de Información y Documentación, vol. 13, n. 1, pp. 115-132. 
d) Por soporte, solamente un 29\% permanecen ajenos a la edición electrónica, predominando la doble versión en el 50\% de los casos (Gráfico VII)

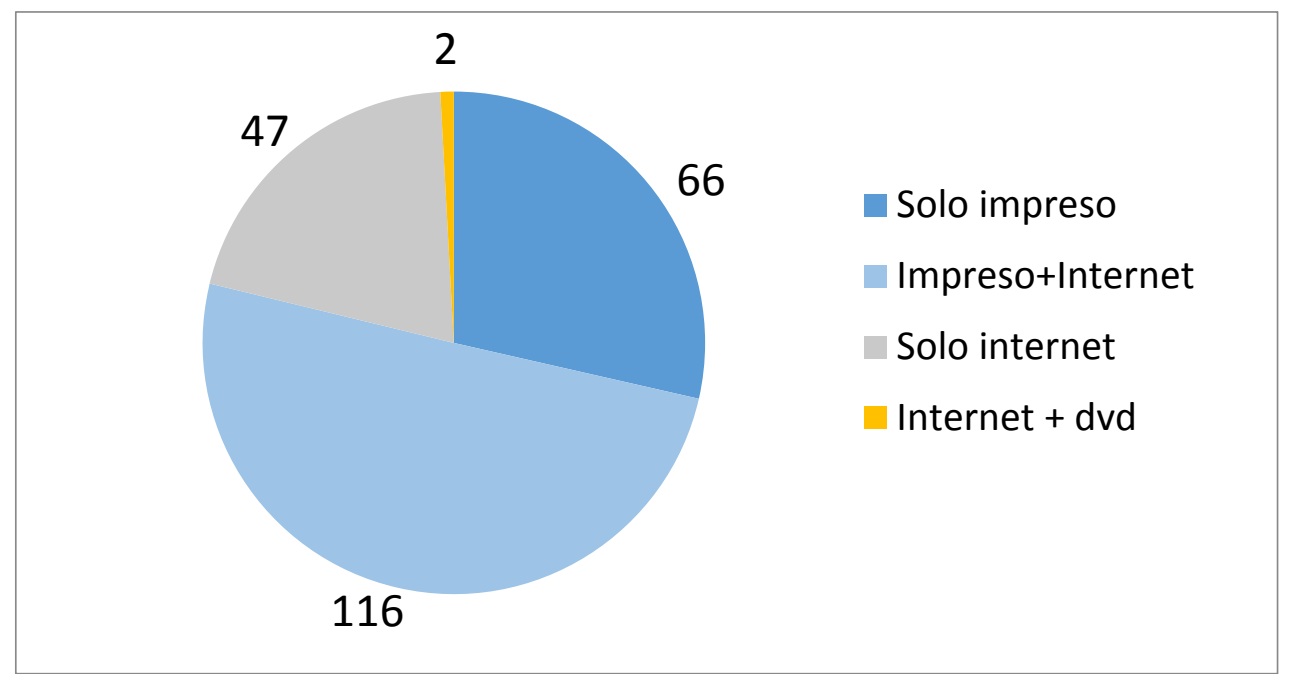

Gráfico VII: Revistas vigentes de Historia en la base de datos ISOC, por formato de edición. Elaboración propia, consulta 15/03/2016.

Estos datos muestran que la edición electrónica ha ido ganando terreno en los últimos años y ya es predominante. Los estudios anteriores sobre revistas españolas de ciencias sociales y humanidades realizados a inicios del siglo $\mathrm{XXI}^{36}$ reflejaban aún la pervivencia del formato impreso, pues cifraban en el $86 \%$ las publicaciones exclusivamente en papel.

\subsection{Sistema experimental aplicado en la base de datos ISOC}

Entre septiembre de 2014 y junio de 2015 se llevaron a cabo una serie de estudios con una metodología experimental, de cara a aprovechar los registros de la base de datos ISOC del CSIC para el establecimiento de una nueva categorización aplicada a la selección de revistas ${ }^{37}$. La propuesta se basa en un sistema multivariable alternativo a los análisis de citación que tenga en cuenta diferentes aspectos básicos que deben exigirse a las revistas de calidad: trayectoria estable, internacionalidad y ausencia de

\footnotetext{
${ }^{36}$ OSCA y MATEO (2003), op. cit.

${ }^{37}$ J.I. VIDAL LIY y L. RODRÍGUEZ YUNTA (2015) “Categorización de revistas científicas españolas en las bases de datos ISOC”. En: XII Congreso ISKO España y II Congreso ISKO España-Portugal: Organización del conocimiento para sistemas de información abiertos. Murcia: Universidad de Murcia.
} 
endogamia, hasta ahora medidas de forma insuficiente en estudios precedentes. Para ello se plantea:

a) Una medida de la trayectoria que no se base exclusivamente en la antigüedad por su fecha de inicio, sino que valore el cumplimiento de la periodicidad y la producción a lo largo de 10 años, así como la valoración obtenida en sistemas que valoran la calidad de los procesos editoriales (Latindex y Sello de calidad FECYT).

b) Una medida de la endogamia basada en la apertura en la autoría con independencia de la entidad que figure como editora. Su medida se realiza tanto por el porcentaje de repetición de los mismos autores como por la concentración de su procedencia institucional, sea o no la entidad editora.

c) Una medida de la internacionalidad que tiene en cuenta tanto la utilización de diferentes idiomas, con especial peso para el inglés, como la variedad en los diferentes países que figuran en la adscripción institucional de los autores, y la presencia en bases de datos internacionales.

El sistema aplicado, tras algunos ajustes, valoró 9 indicadores con una gradación en los baremos de 0 a 3 puntos en cada uno. La suma total permitió categorizar en cuatro grupos A-B-C-D la calidad de las revistas de varias de las disciplinas analizadas. El estudio se aplicó a diferentes disciplinas: Antropología, Arqueología y Prehistoria, Biblioteconomía y Documentación, Geografía, Historia y Lingüística. Finalmente se realizó una comparación multidisciplinar sobre los conjuntos de las revistas con el sello de calidad FECYT y las seleccionadas por Web of Science o Scopus.

El estudio inicial en el área de Historia tuvo una adenda en febrero de 2015 para incorporar las modificaciones en el sistema de indicadores en la segunda fase del estudio experimental ${ }^{38}$. Las publicaciones que obtuvieron mejor puntuación fueron Revista de Historia Económica, Revista de Indias, Anuario de Estudios Americanos, Dynamis y Melanges de la Casa de Velázquez. En general, quedaron mejor valoradas las publicaciones de Historia económica, Historia de la ciencia, Historia de América e Historia contemporánea, que las de otras especialidades, pero esto se relaciona con un mayor grado de internacionalidad y menor endogamia, que es lo que se trataba de

38 L. RODRÍGUEZ YUNTA (2014-2015) Categorización de las revistas españolas de Historia: Propuesta de indicadores sobre trayectoria, apertura de la autoría e internacionalidad en el periodo 2004-2013. Documento de trabajo ISOC 2014/02 y Addenda en Febrero de 2015. Madrid: Centro de Ciencias Humanas y Sociales. 
reflejar.

En la comparación con otras disciplinas la Historia obtuvo unos resultados intermedios $^{39}$, por debajo de áreas mejor calificadas como Lingüística y Antropología.

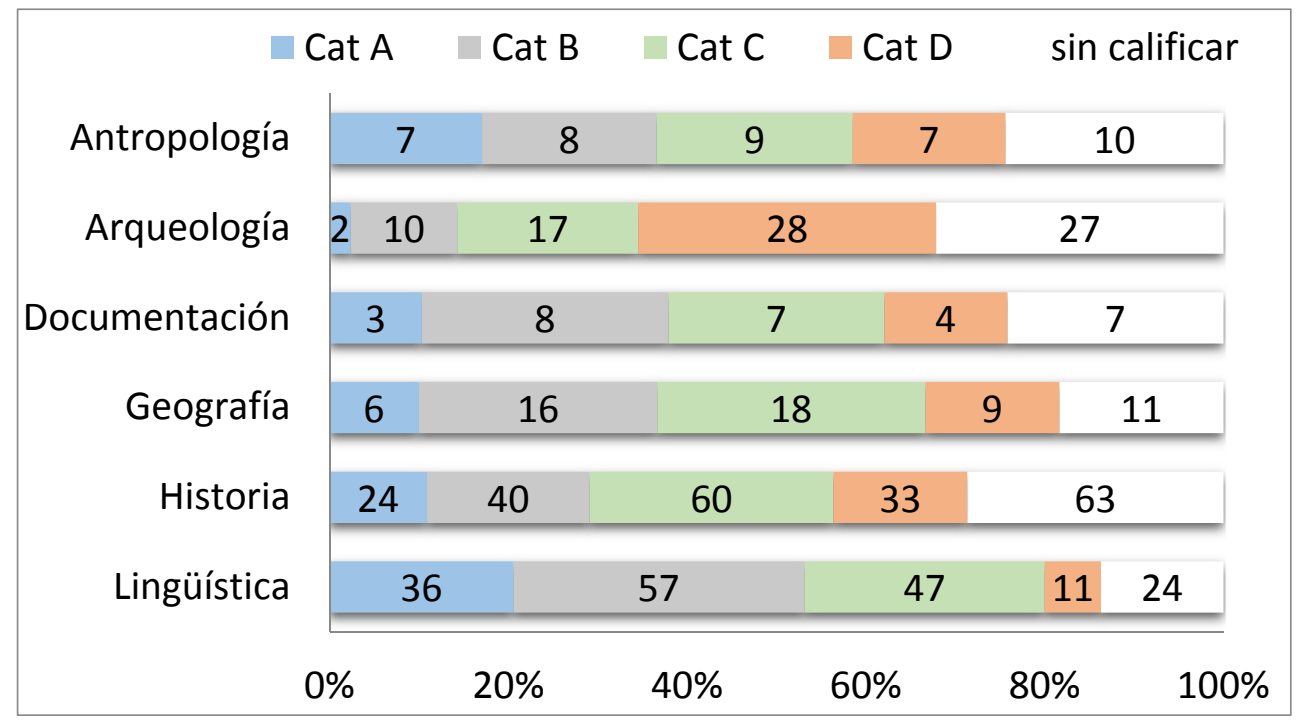

Gráfico VIII. Resultados obtenidos en la propuesta de categorización de revistas aplicada en la base ISOC en 2014-2015 ${ }^{40}$.

Uno de los aspectos que destaca negativamente en el área de Historia (gráfico VIII), es la elevada cantidad de revistas sin calificar. Dentro de este grupo se incluyen aquellos títulos que no cumplían los mínimos establecidos para ser evaluadas, por no haber editado ningún número en los últimos 3 años, ser títulos muy jóvenes, o por la ausencia de datos de afiliación de autores. En el informe del área de Historia se analizaron 157 títulos, con una producción media de 14,6 artículos al año. Los resultados fueron especialmente bajos en los indicadores de internacionalidad, mostrando un enfoque predominantemente nacional. Así, por ejemplo, solamente el $5,5 \%$ de los textos se editaron en inglés y el $76{ }^{\prime} 4 \%$ de los autores se adscribían a instituciones españolas. En 100 casos (64\%) las revistas no figuran en ninguna base de datos internacional.

\footnotetext{
${ }^{39}$ RODRÍGUEZ YUNTA (2014-2015), op. cit.

${ }^{40}$ Publicado en VIDAL y RODRÍGUEZ YUNTA, op. cit.
} 


\section{BASES DE DATOS E INVESTIGACIÓN HISTÓRICA EN EL ENTORNO DE LAS HUMANIDADES DIGITALES}

Bajo la etiqueta genérica de Humanidades digitales se encuadran diferentes líneas de trabajo sobre la aplicación de las tecnologías de la información en Ciencias Humanas y Sociales. Una de estas nuevas tendencias radica en el empleo de las bases de datos para el análisis de fuentes históricas digitalizadas, e igualmente de la producción historiográfica.

Los estudios cienciométricos no se limitan al análisis de citas. Hay otros indicadores alternativos que pueden extraerse de las bases de datos bibliográficas: producción por años, idiomas, autores más frecuentes, género en la autoría, temas tratados, procedencia de los autores, coautoría y colaboración (análisis de redes), la internacionalidad en la autoría o la internacionalidad en la temática. Otros aspectos pueden analizarse a partir de los datos descriptivos de cada revista: internacionalidad de los consejos editoriales, presencia en bases de datos, porcentajes de rechazo,...

La base de datos ISOC puede suministrar datos para el análisis de la historiografía publicada en España. A modo de ejemplo, el gráfico IX permite comparar el interés suscitado por el estudio de la guerra civil española, mantenido en el tiempo aunque con variaciones notables, frente a los trabajos en torno al 98, con un claro efecto de la conmemoración del centenario.

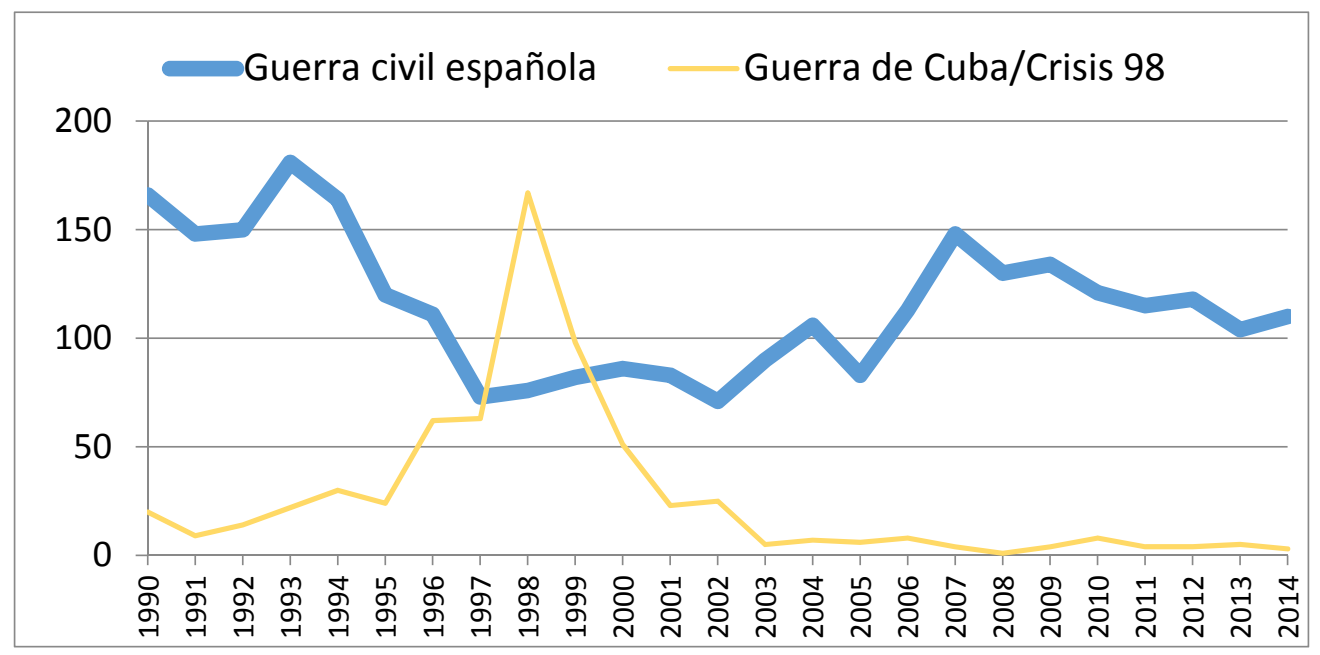

Gráfico IX: Registros con el descriptor "guerra civil española" en comparación a ("guerra de Cuba" o "Crisis del 98") en la base de datos ISOC. Elaboración propia, búsqueda realizada el 28/03/2016 
El análisis bibliométrico de la producción historiográfica sobre la guerra civil española fue abordado por Rosario Ruiz y Sergio Riesco ${ }^{41}$. En su estudio se destacaba la gran diversidad de autores que realizaron publicaciones sobre este tema, la descompensación en los diferentes aspectos temáticos tratados y el desequilibrio regional en las áreas geográficas objeto de estudio. Además de este modelo de análisis cuantitativo global, las bases de datos bibliográficas permiten comparar periodos en la historiografía, y analizar los cambios producidos. En la tabla III se muestran los descriptores más frecuentes que acompañan al término Franquismo por diferentes períodos de publicación, extraídos de la base de datos ISOC. La comparación permite visualizar cómo han disminuido en las revistas españolas líneas muy tratadas en la década de 1980, como la literatura y el exilio, frente a enfoques emergentes como la memoria histórica y los estudios sobre la mujer.

\begin{tabular}{|l|l|l|}
\hline \multicolumn{1}{|c|}{$\mathbf{1 9 8 0 / 8 9}$} & \multicolumn{1}{|c|}{$\mathbf{1 9 9 0 / 9 9}$} & \multicolumn{1}{c|}{$\mathbf{2 0 0 0 / 2 0 1 5}$} \\
\hline 1- Guerra civil española & 1- Primer franquismo & 1- Primer franquismo \\
2- Oposición política & 2- Oposición política & 2- Guerra civil española \\
3- Transición política & 3- Transición política & 3- Represión política \\
4- Posguerra & 4- Guerra civil española & 4- Transición política \\
5- Represión política & 5- Relaciones internacionales & 5- Memoria histórica \\
6- Primer franquismo & 6- Política exterior & 6- Mujeres \\
7- Política exterior & 7- Represión política & 7- Propaganda política \\
8- Literatura española & 8- Propaganda política & 8- Oposición política \\
9- Segunda república & 9- Diplomacia & 9- Posguerra \\
10-Exilio & 10-Segunda República & 10-Antifranquismo \\
\hline
\end{tabular}

Tabla III. Descriptores más frecuentes que acompañan al término Franquismo en la indización por materias de los registros de la base de datos ISOC. Elaboración propia, búsqueda realizada el 15/03/2016.

\section{CONCLUSIONES}

Aunque investigadores y editores de la disciplina de Historia están cambiando para adaptarse a los parámetros de las ciencias sociales, aún es mucho el camino por recorrer hasta los niveles de solidez que han alcanzado las revistas en las ciencias experimentales. Son muchos los retos que aún deben enfrentarse. En especial, las revistas deben aprovechar las ventajas de la globalización en Internet para liberarse de

${ }^{41}$ M.R. RUIZ FRANCO y S. RIESCO ROCHE (1999) "Veinte años de producción histórica sobre la guerra civil española (1975-1995): una aproximación bibliométrica". Revista Española de Documentación Científica, vol. 22, n. 2, pp. 174-197. 
los enfoques localistas. Las publicaciones aumentan su calidad cuando reciben mayor número de postulaciones para publicar, la internacionalidad y la difusión son elementos clave para una política de mejora continua.

El factor de impacto o los indicadores alternativos basados en citas, tiene un valor relativo y deberían adaptarse mejor a las pautas de citación de las Humanidades. No obstante, la Historia como otras disciplinas de Ciencias Humanas y Sociales, mejoraría sus resultados si se produjera una mayor concentración de la edición en revistas frente al libro, con publicaciones de prestigio, con un sistema garantizado de revisión y una mayor producción de artículos al año. La dispersión de títulos dificulta tanto la visibilidad de la producción como el rigor de la revisión en el proceso editorial. El reto es aprovechar la potencialidad de la era digital para crear una comunidad internacional en torno a revistas con capacidad para ser un referente esencial en el avance de la investigación.

En ningún caso debería aplicarse la citación como única variable para medir la calidad. Otros sistemas que valoran la presencia en bases de datos continúan considerando un factor esencial la presencia en los índices de citas, de forma que se mantiene una alta dependencia frente a estos productos. Inicialmente los criterios Latindex, pese a basarse en aspectos formales, pudieron ser utilizados para establecer un filtro de calidad de las revistas españolas. Pero éstas han mejorado notablemente en la última década; actualmente un alto cumplimiento de los criterios Latindex solo puede interpretarse como una valoración de requisitos mínimos

Las bases de datos documentales han perdido su papel central en la búsqueda de referencias bibliográficas. Sin embargo, aportan una función esencial para establecer parámetros alternativos para la evaluación de las publicaciones y estudios estadísticos sobre la producción científica. Su rol puede verse potenciado por la expansión de las denominadas Humanidades Digitales.

\section{BIBLIOGRAFÍA}

ABEJÓN PEÑA, T.; MALDONADO MARTÍNEZ, A.; RODRÍGUEZ YUNTA, L. y RUBIO LINIERS, M.C. (2009). "La base de datos ISOC como sistema de información y fuente para el análisis de las ciencias humanas y sociales en España”. El Profesional de la Información, vol. 18, n. 5, pp. 521-528. http://dx.doi.org/10.3145/epi.2009.sep.05

ABEJÓN PEÑA, T. y RODRÍGUEZ YUNTA, L. (2015). "La participación española en Latindex: valoración de resultados e impacto sobre la calidad y evaluación 
de las publicaciones científicas".Ciência da Informação, vol. 44, n. 2., pp. 258-275. http://revista.ibict.br/ciinf/article/view/1795/2371

ALCAIN PARTEARROYO, M.D.; ROMÁN ROMÁN, A. y GIMÉNEZ TOLEDO, E. (2008). "Categorización de las revistas españolas de Ciencias Sociales y Humanas en RESH". Revista Española de Documentación Científica, vol. 31, n. 1, pp. 85-95.http://dx.doi.org/10.3989/redc.2010.3.735

ALEIXANDRE-BENAVENT, R.; VALDERRAMA-ZURIÁN, J.C. y GONZÁLEZALCAIDE, G. (2007). "El factor de impacto de las revistas científicas: limitaciones e indicadores alternativos". El Profesional de la Información, vol. 16, n. 1, pp. 4-11.http://dx.doi.org/10.3145/epi.2007.jan.01

ALONSO GAMBOA, J.O. (2000). "Iniciativas para aumentar la visibilidad de las revistas latinoamericanas: la aportación de CLASE, PERIÓDICA y LATINDEX". En: Las revistas científicas latinoamericanas: su difusión y acceso a través de bases de datos, $8^{a}$ Reunión sobre Revistas Académicas y de Investigación. México: UNAM, pp. 62-72.http://hdl.handle.net/10760/12892

AYLLÓN MiLlÁN, J. M.; MARTÍN MARTÍN, A.; ORDUÑA MALEA, E. y DELGADO LÓPEZ-CÓZAR, E. (2015). Índice H de las revistas cientificas españolas según Google Scholar Metrics (2010-2014). Granada: EC3. (EC3 Reports; 13). http://hdl.handle.net/10481/36998

BEIGEL, F. y SALATINO, M. (2012). "Circuitos segmentados de consagración académica: las revistas de Ciencias Sociales y Humanas en la Argentina". Información, cultura y sociedad, n. 32, pp. 11-35. http://revistascientificas.filo.uba.ar/index.php/ICS/article/view/1342

BLANCO FAURA, I. (2009) "Revistas electrónicas de Historia de América en red". Naveg@merica. Revista electrónica de la Asociación Española de Americanistas, n. 2.http://revistas.um.es/navegamerica/article/view/55691

BORREGO, Á. y URBANO, C. (2006). "La evaluación de revistas científicas en Ciencias Sociales y Humanidades". Información, cultura y sociedad, 2006, n. 14, pp. 11-27. http://www.scielo.org.ar/pdf/ics/n14/n14a02

DELGADO LÓPEZ-CÓZAR, E. y CABEZAS-CLAVIJO, A. (2012). "Google Scholar Metrics: an unreliable tool for assessing scientific journals". El Profesional de la Información, vol. 21, n. 4, pp. 419-427. http://dx.doi.org/10.3145/epi.2012.jul.15

DI VAIO, G.; WALDENSTRÖM, D. y WEISDORF, J. (2012). "Citation success: Evidence from economic history journal publications". Explorations in 
Economic History, n. 49, pp. 92-104. http://dx.doi.org/10.1016/j.eeh.2011.10.002

FERNÁNDEZ IZQUIERDO, F.; OSCA LLUCH, J.; LÓPEZ, M.; SENDRA ROIG, J. y RUBIO LINIERS, M.C. (2010). "Problemas planteados en la creación de índices de citas en el área de Humanidades: la base de datos Modernitas Citas y las publicaciones de Historia Moderna". Revista Española de Documentación Científica, vol. 33, n. 3, pp. 498-505. http://dx.doi.org/10.3989/redc.2010.3.729

FLORES, A. M.; PENKOVA, S. y ROMÁN ROMÁN, A. (2009). "Once años de LATINDEX: una experiencia al servicio de las publicaciones científicas iberoamericanas". Simbiosis, vol. 6,n. 1.http://hdl.handle.net/10261/22942

MALALANA UREÑA, A. (2007a). "Visibilidad internacional de las Revistas Españolas de Historia Moderna". Cuadernos de Historia Moderna, vol. 32, pp.

193.http://revistas.ucm.es/ghi/02144018/articulos/CHMO0707110159A.PDF

MALALANA UREÑA, A. (2007b). "Visibilidad internacional de las revistas españolas de historia medieval". En la España Medieval, vol. 30, pp. 455496http://revistas.ucm.es/index.php/ELEM/article/view/ELEM0707110455A $\underline{121547}$

MALALANA UREÑA, A. (2007c). "Visibilidad internacional de las revistas españolas de historia contemporánea". Studia Histórica. Historia Contemporánea, $\quad$ n. 25, pp. 445-485. http://gredos.usal.es/jspui/bitstream/10366/80237/1/Visibilidad internacional de las revista.pdf

MALALANA UREÑA, A.; ROMÁN ROMÁN, A. y RUBIO LINIERS, M. C. (2007). "Visibilidad internacional de las revistas españolas de historia". Scripta Nova, vol. 11, n. 234.http://www.ub.edu/geocrit/sn/sn-234.htm

MIKELARENA PEÑA, F. (2007). "Parámetros de calidad de las revistas científicas españolas sobre historia moderna y contemporánea". Huarte de San Juan. Geografia e Historia, n. 14, pp. 297312.https://dialnet.unirioja.es/descarga/articulo/2648872.pdf

OSCA LLUCH, J. y MATEO MARQUINA, M. E. (2003). "Difusión de las revistas españolas de ciencias sociales y humanidades. Acercamiento bibliométrico". Revista General de Información y Documentación, vol. 13, n. 1, pp. 115132.http://revistas.ucm.es/index.php/RGID/article/view/RGID0303120115A 
RODRÍGUEZ YUNTA, L. (2014-2015). Categorización de las revistas españolas de Historia: Propuesta de indicadores sobre trayectoria, apertura de la autoría e internacionalidad en el periodo 2004-2013. Documento de trabajo ISOC 2014/02 y Addenda en Febrero de 2015. Madrid: Centro de Ciencias Humanas y Sociales. http://hdl.handle.net/10261/103402

ROMÁN ROMÁN, A. y GIMÉNEZ TOLEDO, E. (2010). "Cómo valorar la internacionalidad de las revistas de Ciencias Humanas y su categorización en ERIH". Revista Española de Documentación Científica, vol. 33, n. 3, pp. 341377. http://dx.doi.org/10.3989/redc.2010.3.735

ROMÁN ROMÁN, A.; VÁZQUEZ VALERO, M. y URDÍN CAMINO, C. (2002). "Los criterios de calidad editorial Latindex en el marco de la evaluación de las revistas españolas de Humanidades y Ciencias Sociales". Revista Española de Documentación Científica, vol. 25, n. 3, pp. 286303.http://dx.doi.org/10.3989/redc.2002.v25.i3.109

RUBIO LINIERS, M.C. (2005). "Evaluación y normalización de las revistas científicas españolas de Historia local". En: VII Encuentro de Primavera sobre Contenidos, edición y difusión de las revistas cientificas de historia local, El Puerto de Santa María (Cádiz). http://hdl.handle.net/10760/8828

RUIZ FRANCO, M.R. y RIESCO ROCHE, S. (1999). "Veinte años de producción histórica sobre la guerra civil española (1975-1995): una aproximación bibliométrica". Revista Española de Documentación Científica, vol. 22, n. 2, pp. 174-197. http://dx.doi.org/10.3989/redc.1999.v22.i2.337

SANZ, E.; CASTRO, F.; POVEDANO, E.; et al. (2002). "Creación de un índice de citas de revistas españolas de Humanidades para el estudio de la actividad investigadora de los científicos de estas disciplinas". Revista Española de Documentación Científica, vol. 25, n. 4, pp. 443-454. http://redc.revistas.csic.es/index.php/redc/article/view/278/334

VAL VALDIVIESO, M.I. DEL (2014). "La evaluación de las publicaciones científicas en España: las revistas de Historia". Mélanges de la Casa de Velázquez, vol. 44, n. 2, pp. 307-311.

VIDAL LIY, J.I. y RODRÍGUEZ YUNTA, L. (2015). "Categorización de revistas científicas españolas en las bases de datos ISOC". En: XII Congreso ISKO España y II Congreso ISKO España-Portugal: Organización del conocimiento para sistemas de información abiertos. Murcia: Universidad de Murcia. http://www.iskoiberico.org/wp-content/uploads/2015/11/25 Vidal.pdf 

Sección III: INVESTIGADORES NOVELES 



\title{
"A VOS EL PODEROSO Y MUY ESTIMADO REY DE LA CHINA". PRIMERA EMBAJADA REGIA DE FELIPE II CON DESTINO A LA CHINA DE LA DINASTÍA MING: ORIGEN, PREPARACIÓN Y ABANDONO
}

\section{FIRST EMBASSY OF PHILIP II DESTINED FOR THE CHINESE MING DINASTY: ORIGIN, PREPARATION AND ABANDONMENT}

\author{
Chenguang Li ${ }^{2}$ \\ Universidad Autónoma de Madrid \\ beingmonring@hotmail.com
}

\begin{abstract}
RESUMEN: El presente artículo analiza un acontecimiento significativo pero poco conocido: la primera embajada que Felipe II envió a China. Através de las fuentes relativas a esta expedición, podemos contemplar cómo funcionaba la administración de la Castilla del siglo XVI en lo que concierne a los asuntos diplomáticos. Además, cabe prestar especial atención a la carta escrita por Felipe II y dirigida al emperador de China. Con ella, no solo podemos ampliar nuestros conocimientos sobre el monarca hispano en relación con sus perspectivas sínicas, sino que también nos permite observar las estrategias y los métodos adoptados para crear contactos con aquel imperio.
\end{abstract}

\footnotetext{
${ }^{1}$ Archivo General de Indias (AGI más adelante), Patronato, 24, R. 51.Se trata de una frase de la carta escrita por Felipe II al emperador chino de la dinastía Ming, en 1580. Presentaremos la carta más adelante detalladamente. Cfr. I. RODRÍGUEZ RODRÍGUEZ (1976). Historia de la provincia agustiniana del Santísimo Nombre de Jesús de Filipinas. Vol. X. Valladolid: Estudio Agustiniano, pp. 44-46; C. HSU (2004). "Dos cartas de Felipe II al emperador de China". eHumanista: Journal of Iberian studies. Vol. 4, pp. 194-209; "China en España. Elaboración de un corpus digitalizado de documentos españoles sobre China de 1555 a 1900". Universitat Pompeu Fabra, <https://www.upf.edu/asia/projectes/che/principal.htm $>$ [Consultado: 28-122015].

Agradezco sinceramente a la profesora Elena Postigo Castellanos, mi directora de tesis y catedrática de la Universidad Autónoma de Madrid. Al redactar este artículo, me ha ofrecido muchos consejos y correcciones de gran utilidad. De manera muy especial, al profesor Jesús Paniagua Pérez, catedrático de la Universidad de León, gracias por su inmensa ayuda, tan generosa y desinteresada, a la hora de mejorar cada detalle del trabajo.

${ }^{2}$ Becario del gobierno chino y doctorando en el programa de Doctorado interuniversitario en Historia Moderna por la Universidad Autónoma de Madrid y por la Universidad de Cantabria, reconocido por la ANECA con mención de excelencia (plan de estudio RD 1393/2007).
} 
PALABRAS CLAVE: Felipe II, Embajada, China, Carta regia, Siglo XVI

ABSTRACT: The present article analyzes a profound significance but rarely known historical event: The first diplomatic mission of the Emperor Philip II sending to China. We can approach and understand the decision-making mechanism of the Spanish government to complete such diplomatic missions in sixteenth century. In addition, Philip II once wrote to the Chinese emperor one letter, through which we can not only know the Spanish monarch's familiarity and relevant knowledge of China, but also can observe the methods and tactics that Philip II used in his attempt to establish diplomatic relations with that Empire.

KEY WORDS: Philip II, Embassy, China, Royal Correspondence letter, XVI Century

\section{EL ORIGEN DE LA EMBAJADA REGIA DE FELIPE II CON DESTINO A CHINA}

Los castellanos, entusiasmados con sus hazañas en el Nuevo Mundo, llegaron a sentirse capaces de empresas aún mayores y comenzaron a plantear repetidamente proyectos sobre la conquista de China,una vez que se establecieran en las Filipinas. Algo parecido a lo que sucedería con el imperio nipón, al que se enviaría una embajada en 1592 al mando del capitán Lope del Llano y del dominico Juan Cobo, con dos chinos cristianos de Manila como intérpretes.

Según la relación de Alfonso de Arellano, capitán del patache San Lucas, que era una de las tres naves que salieron de Nueva España con Miguel López de Legazpi el 21 de noviembre de 1564 hacia el Poniente, China se consideraba como destino final por los miembros de aquella empresa "por que decían, que ellos no havían venido a la China para cortar palos, sino que en llegando havian de cargar de oro"3. En la expedición iban tres agustinos: Diego de Herrera, Martín de Rada y Pedro de Gamboa ${ }^{4}$. El primer proyecto relativo al país oriental fue propuesto en 1565, al año siguiente de la llegada de la expedición a las Filipinas. En la propuesta, se formuló una idea muy precisa que se podía interpretar como acercarse a China con doble finalidad que son el comercio y la conquista:

Si v. magestad fuere servido que se vea por vista de ojos

esta tierra yo me ofrezco dándome dos navíos de doscientas

${ }^{3}$ Colección de documentos inéditos relativos al descubrimiento, conquista y organización de las antiguas posesiones españolas de ultramar. Tomo núm. 3., II De las islas Filipinas, Madrid: Estab. Tip. Sucesores de Rivadeneyra. (1887), p. 36.

${ }^{4}$ AGI, Audiencia de Filipinas, 29, N. 2. 
"A vos el poderoso y muy estimado Rey de la China". Primera embajada regia de Felipe II con destino a la China de la dinastía Ming: origen, preparación y abandono

y cinquenta toneladas poco más o menos y con quarenta soldados en cada uno y la artillería municiones y bastimentos necesarios con el favor de nuestro señor, llevando alguna orden de embaxada al señor de la tierra de entrar en ella pormi propia persona y bolver costeándola para la Nueva España y ver la orden que se deve de tener assí para la contratación de la tierra como para la conquista[... $]^{5}$.

Desde el primer viaje hacia las Filipinas, los castellanos desembarcaron primero en la zona central de aquel archipiélago, las islas Bisayas. Nada más conseguir establecerse en Cebú, Legazpi escribió al virrey de Nueva España el 27 de julio de 1570 y en el mismo año también a Felipe II pidiendo instrucciones para los siguientes proyectos en las Filipinas:

También querría estar acerto de la voluntad de su magestad si es de cobrar a Maluco y lo que más le pertenece de aquella parte, porque para esto está más cómodo el asiento de Cebú que otro ninguno de los que sea nuestro en estas islas por la bondad del puerto, pero si su magestad pretende que sus ministros se estiendan a la parte del Norte y costa de China, tengo por más acertado de hazer asiento en la ysla de Luçón 6 .

El desplazamiento del centro de poder desde Cebú a Manila, en 1571, respondió a la cuestión planteada por el Adelantado. La decisión fue justificada por múltiples razones, aunque las principales serían la cercanía a la China y la oportunidad de tener contactos directos con aquel gigantesco imperio ${ }^{7}$, teniendo en cuenta que la ciudad de

\footnotetext{
${ }^{5}$ Ibídem, p. 239. El autor de esta relación podría ser Juan de la Isla aunque no existía la firma en el documento original.

${ }^{6}$ AGI, Patronato, 24, R. 9.En cuanto a la carta destinada a Felipe II, al tratar de los asuntos sobre China, Legazpi utilizó casi las mismas palabras, véase F. COLÍN (1900-1902). Labor evangélica, ministerios apostólicos de los obreros de la Compañia de Iesvs, fundacion, y progressos de su provincia en las islas Filipinas. II. Barcelona: Imp. y Lit. de Henrich, p. 662. ${ }^{7}$ Sobre las razones del desplazamiento del centro de operaciones castellano en las Filipinas hasta Manila, véase J.A. CERVERA (2013). Tras el sueño de China: Agustinos y dominicos en Asia Oriental a finales del siglo XVI. Madrid: Plaza y Valdés, pp. 152-154; P. HIDALGO NUCHERA (1995). Encomienda, tributo y trabajo en Filipinas (1570-1608). Madrid: Universidad Autónoma Polifemo, pp. 26-27; A. GARCÍA-ABÁSOLO (2012). Murallas de piedra y cañones de seda: chinos en el Imperio español (siglos XVIXVIII). Córdoba: Servicio de Publicaciones, Universidad de Córdoba, D. L., pp. 78-85; L.
} 
Manila se situaba en una bahía de la costa occidental de Luzón, en la isla más grande del Archipiélago y también la más próxima al continente. Desde Manila los castellanos continuaron proyectando sus empresas para acercarse a la China de los Ming. Sin embargo, el plan de tener contactos directos con los chinos no se cumplió hasta 1571, no como resultado de que los castellanos pasasen al Imperio Celeste, sino porque los chinos siguieron manteniendo contactos con las islas, como lo habían hecho siempre: "Estando surta en Mindoro la armada, llegó allí un junco grande de chinos corriendo un recio temporal, en que se hubieran evidentemente perdido y dado al través si el Adelantado no hubiera enviado a socorrerles [...]"8. Un año después de este suceso, en 1572, un grupo de comerciantes, de los que habían sido rescatados por el Adelantado el año anterior, llegaron a Manila con un cargamento de mercancías de su tierra natal. Este acontecimiento abrió una cadena de relaciones que llevan al rey Prudente a atender cada vez más peticiones y proyectos referentes a China, todos ellos propuestos por sus oficiales tanto de Castilla como de las colonias. Entre ellos, cabe destacar la expedición mandada por el entonces virrey de Nueva España, Martín Enríquez de Almansa, en 1572. Según las instrucciones, el capitán Juan de la Isla debería explorar la costa de la China y recopilar informaciones útiles sobre aquel imperio. Desgraciadamente, el viaje finalmente no pudo efectuarse'.

Asimismo, cabe señalar que fueron los hijos de san Agustín quienes estuvieron presentes en los primeros años de la presencia castellana en el archipiélago asiático. Algunos de ellos como Diego de Herrera y Martín de Rada, que mencionaremos más adelante, denunciaban constantemente a los conquistadores de las Filipinas por sus actividades dañosas para los indígenas y la manera en que se llevaban a cabo los repartimientos; estos mismos frailes comenzaron muy pronto a proponer el establecimiento de relaciones amistosas con los chinos para poder predicar la fe católica en el Imperio Celeste. Frente a aquellas pretensiones, los españoles asentados en Filipinas y enfrentados con los misioneros, amenazaban con el abandono, ya que a

DÍAZ-TRECHUELO (2001). Filipinas. La gran desconocida (1565-1898). Pamplona: EUNSA, p. 71; M. OLLÉ (2002). La empresa de China: de la Armada Invencible al Galeón de Manila, Barcelona: Acantilado, pp. 39-48, etc.

${ }^{8}$ G. de SAN AGUSTÍN (1975). Conquista de las Islas Filipinas (1565-1615). Madrid: CSIC, pp. 329-330.

${ }^{9}$ Las instrucciones dadas por el virrey de Nueva España, don Martín Enríquez al Juan de la Isla sobre lo que debe realizar durante el descubrimiento de la China, véase AGI, Patronato, 24, R. 4. 
"A vos el poderoso y muy estimado Rey de la China". Primera embajada regia de Felipe II con destino a la China de la dinastía Ming: origen, preparación y abandono

ello se unía la crisis alimenticia y una mala situación económica ${ }^{10}$.

Fue Diego de Herrera ${ }^{11}$ quien manifestaba a Felipe II, desde México, en un momento relativamente temprano, el 16 de enero de 1570 lo siguiente: "tan de çerca de Çubú [Cebú] ay tierras tan grandes y tan ricas, y son de vuestra Magestad, como son China, lequios, jauos, japones, tubimos entendido mandado yr a ellas y dexar estas $y_{\text {slas" }}{ }^{12}$. Es más, este mismo fraile, provincial de la Orden agustiniana en las Filipinas entre 1569 y 1572, tuvo la oportunidad de volver a la Península para informar personalmente al rey Prudente sobre los asuntos de la nueva colonia asiática: "con los nuevos operarios que conducía a estas islas para la propagación de la fe, no solo en ellas, sino también en las de este archipiélago y en el dilatado imperio de la China"13. Afortunadamente, el viaje de este fraile, sobre todo la entrevista con Felipe II el 15 de septiembre de 1574 en Madrid, fue descrita por otro destacado agustino de los siglos XVI y XVII, Juan González de Mendoza ${ }^{14}$, el autor de la esclarecida e influyente obra,

${ }^{10}$ Acerca de la crisis en los primeros años en las Filipinas, véase J. GAYO Y ARGAÓN (1950). Ideas jurídico-teológicas de los religiosos de Filipinas en el siglo XVI sobre la conquista de las islas. Manila: Universidad de Santo Tomás; P. NUCHERA HIDALGO (1993). Las polémicas iglesias-estado en las Filipinas. Córdoba: Universidad de Córdoba, etc.

${ }^{11}$ Nació Diego de Herrera en la localidad de Recas de Toledo y murió en 1576 en el mar de Filipinas como consecuencia de un naufragio. Se embarcó rumbo a aquellas islas junto con Legazpi en 1564. Más tarde llegó a ser elegido superior de la misión agustina en la nueva colonia y desempeñó el cargo entre 1569 y 1572. En 1569 decidió volver a la Península en busca de más religiosos para las Filipinas.

${ }^{12}$ AGI, Patronato, 24, R. 16. Cfr. I. RODRÍGUEZ RODRÍGUEZ (1978). Historia de la provincia agustiniana del Santísimo Nombre de Jesús de Filipinas. Vol. XIV. Manila: Convento de San Agustín, pp. 37-40.

${ }^{13}$ G. de SAN AGUSTÍN (1975). op. cit., p. 471.

${ }^{14}$ Juan González de Mendoza (1545-1618) nació en Torrecilla de Cameros, en La Rioja. A la edad de diecisiete años se trasladó a México, donde tomó el hábito agustiniano en 1564. En 1574, el Padre Mendoza acompañó al Padre Herrera desde Nueva España cuando regresaba a la Península. Desembarcaron en Sanlúcar de Barrameda el 13 de agosto del mismo año. Juan González de Mendoza permaneció desempeñando algunos cargos en los conventos de Soria, Granada, Madrid, etc., hasta que en 1581 se desplazara a China como embajador de Felipe II, siendo portador de regalos para el emperador. Después de diez meses de infructuosa espera en Nueva España, regresó para comunicar al monarca el abandono de la expedición por consejo de las autoridades virreinales. En 1584 el Padre Mendoza se trasladó a Roma y allí publicó, en 1585, la primera edición en castellano de su obra Historia de las cosas más notables, ritos y costumbres del gran Reino de la China, que entre 1585 y 1600 fue traducida y publicada 38 veces por toda Europa. Durante los años siguientes le vemos desarrollar su actividad en Castilla, Italia y América ocupando varios cargos de importancia, entre ellos el de obispo de Popayán, 
Historia de las cosas más notables, ritos y costumbres del Gran Reino de la China:

[Felipe II] oyó la petición con mucha satisfacción de que el deseo era santo y provechoso, y díjonos que él mandaría a su Consejo tratase con particular consideración y con la brevedad que se requería de aquel particular[...] excepto de lo que tocaba a la embajada para el rey de la China, que como cosa más importante y que requería más tiempo y mayor acuerdo se difirió para mejor ocasión ${ }^{15}$.

El proyecto relativo a China y propuesto por los castellanos en las Filipinas, una vez entregado por Diego de Herrera, se mantenía en un impase en la corte de Felipe II. Sin embargo, en el mismo año de 1574, al ser nombrado oidor de la Audiencia de México, provisto gobernador y capitán general de Filipinas el doctor Francisco de Sande ${ }^{16}$, le fueron mandadas desde la corte castellana unas primeras instruccionesrespecto a China: "Procuraréis comunicación y trato con los de la China, $y$ de entender la calidad de la gente de aquel reyno y el trato que tienen y de todo nos daréis aviso al nuestro Consejo de las Indias"17.

Más tarde, en 1575 se envió desde el archipiélago filipino, sin permiso real, la primera embajada castellana, que fue recibida oficialmente en China por el gobierno local de la provincia Fujian ${ }^{18}$. El monarca español se enteró de este acontecimiento por

donde murió en 1618. Acerca de la biografía de Juan González de Mendoza y de su eminente obra, véase J. GONZÁLEZ DE MENDOZA (1944). Historia de las cosas mas notables, ritos y costumbres del Gran Reino de la China. Madrid: Aguilar, pp. XIV-XLI; J. GONZÁLEZ DE MENDOZA (1990). Historia del Gran Reino de la China. Madrid: Miraguano; Polifemo, pp. 9-11; M.I. VIFORCOS (1998). "Semblanza de fray Juan González de Mendoza (OSA), embajador de Felipe II a China y obispo de Popayán”. La Ciudad de Dios: revista agustiniana, Número 221, pp. 729-758.

15 J. GONZÁLEZ DE MENDOZA (1944). op. cit., pp. 140-141.

${ }^{16}$ Francisco de Sande (1540-1602), natural de Cáceres, llegó a ocupar algunos cargos muy importantes en América y las Filipinas, entre ellos, oidor de la Audiencia de México y más tarde el gobernador y capitán general de las Filipinas entre 1574 y 1580 . Durante su estancia en las Filipinas escribió algunas cartas a Felipe II, proponiendo la conquista de China, aunque sus proyectos bélicos no fueron tenidos en cuenta por el monarca.

${ }^{17}$ AGI, Audiencia de Filipinas, 339, L. 1, F. 46V-47V.

${ }^{18}$ La delegación formada por los Padres Martín de Rada, Gerónimo Marín y dos soldados más zarpó rumbo a China desde Manila en el junco imperial chino, el 12 de junio de 1575. A través de las manifestaciones de Rada, podemos saber que la embajada castellana tenía una triple finalidad: establecer relaciones de amistad, comerciales y de predicación del cristianismo, conforme a las instrucciones que dio el gobernador de las Filipinas, Guindo de Lavezares. 
"A vos el poderoso y muy estimado Rey de la China". Primera embajada regia de Felipe II con destino a la China de la dinastía Ming: origen, preparación y abandono

los cauces normales de la relación entre las Filipinas y China. Uno de los protagonistas de dicha misión diplomática fue Martín de Rada ${ }^{19}$, del que el monarca comunicó que había leído la carta que le había escrito para informarle de la embajada que se había llevado a cabo en los años precedentes:

El Rey. Benerable y devoto padre fray Martín de Rada, de la Orden de Sant Agustín. Vuestra carta de primero de mayo del año passado de setenta y seis se ha reçibido, y he holgado mucho de entender el muy bueno y christiano zelo con que havéis entendido en la doctrina de los yndios naturales de esas yslas, y el con que fuestéis dellas a la çiudad de Chinchón [Ciudad de la provincia de Fujian, hoy en día Zhangzhou $]^{20}$.

Por esas fechas, comenzarían a aparecer muchas propuestas de los oficiales

Aunque ellos fueron recibidos cordialmente en la provincia china de Fujian, al cabo de treinta y cinco días, se vieron obligados a marcharse de aquellas tierras y regresar a las Filipinas. Sin embargo, según las fuentes de la dinastía Ming, las peticiones y los regalos por parte de la embajada castellana fueron presentados ante el emperador al año siguiente por los oficiales de Fujian. Es más, la corte china estimaba muy positivamente las propuestas de los embajadores castellanos. Desgraciadamente, la semilla sembrada por esta embajada castellana para crear la amistad chino-española durante el siglo XVI no lograría desarrollarse en el futuro. El 4 de mayo de 1576, la segunda embajada castellana, encabezada de nuevo por el Padre Rada, se embarcó con los embajadores chinos desde Manila. Sin embargo, los castellanos fueron abandonados en una isla situada en el camino hacia China. Acerca de las primeras embajadas castellanas con destino a la provincia Fujian de China, véase G. de SAN AGUSTÍN (1975). op. cit., pp. 439467; M. OLLÉ (2002). op. cit., pp. 64-72, etc.

${ }^{19}$ El agustino Martín de Rada nació en 1533 en Pamplona y murió en Filipinas en 1578. Formó parte de la primera expedición liderada por Legazpi hacia las Filipinas, y llegó a ser uno de los hombres más influyentes durante los primeros años de presencia castellana en la nueva posesión. Fue él quien asumió la responsabilidad de encabezar la primera embajada que se desplazó desde las islas a China. Como consecuencia, escribió unas preciosas relaciones y cartas destinadas a Felipe II, informando de las noticias de su misión diplomática y del imperio oriental. En cuanto a la biografía y las obras de Martín de Rada, véase P.G. GALENDE (1980). Apología profilipinos: the quixotic life and chivalric adventures of Fray Martín de Rada, OSA, in defense of the early filipinos. Manila: Salesiana Publishers; M. MERINO (1944). "Semblanzas misioneras: Fr. Martín de Rada, Agustino". Missionalia Hispanica, I, pp. 167212; M.I. OSTOLAZA (2006). "Fray Martín de Rada, evangelizador, cosmógrafo y embajador en China". Huarte de San Juan. Geografía e Historia, Número 13, pp. 177-198, etc.

${ }^{20}$ AGI, Audiencia de Filipinas, 339, L.1, F. 78V. Cfr. I. RODRÍGUEZ RODRÍGUEZ (1976). op. cit., pp. 32-34. La respuesta del monarca al Padre Martín de Rada fue despachada el 18 de abril de 1577 desde Madrid. 
castellanos, especialmente de los asentados en Filipinas, sobre la posible conquista de China. El 7 de junio de 1576, el gobernador de esa posesión castellana en Asia, el mencionado Francisco de Sande remitió a su rey dos cartas en las que el gobernador aconsejaba formalmente la conquista del gigantesco imperio asiático, a la vez que intentaba justificar la legalidad de aquella posible guerra ${ }^{21}$. Sin embargo, este proyecto bélico, como otros más, no fueron apoyados por Felipe II. De hecho, el 29 de abril de 1577 el monarca respondió al gobernador a través de una real cédula firmada en San Martín de la Vega. En ella el rey impugnó el plan de la conquista de China, y exigió más conocimientos sobre aquel país. Es más, en las instrucciones regias, se comenzaba a diseñar una estrategia sobre China basada en las buenas relaciones que los castellanos debían mantener con sus habitantes:

En cuanto a conquistar China, que os parece se debía hacer luego, acá ha parecido que por ahora no conviene se trate de ello, sino que se procure con los chinos buena amistad, y que no os hagáis ni acompañéis con los corsarios enemigos de los dichos chinos, ni déis ocasión para que tengan justa causa de indignación con los nuestros; y así lo haréis, e iréisnos avisando del suceso de todo, que adelante, cuando se tenga mejor entendido lo de aquella tierra, si conviene se haga novedad, se os dará orden de la que en ello se hubiere de tener $[\ldots]^{22}$.

En lo que concierne a la negativa firme de la conquista por la guerra, hay que advertir que durante este tiempo se desarrollaban las leyes relativas a los nuevos descubrimientos y poblaciones. De acuerdo con la profesora Viforcos, la controversia sobre el Nuevo Mundo, especialmente la legitimidad de las conquistas armadas y el requerimiento, se prolongó durante el siglo XVI. Las tesis iusnaturalistas y antibelicistas iban ganando terreno en la Monarquía Católica y la Iglesia, culminando con la promulgación de las Ordenanzas de descubrimiento, nuevas poblaciones y

\footnotetext{
${ }^{21}$ AGI, Audiencia de Filipinas, 6, R. 3, N. 25. En el mismo día, el gobernador Sande elaboró otra carta extensa y más detallada de 127 puntos, ocho de ellos se dedicaban directamente al proyecto de conquista militar de China y la justificación de la guerra con los chinos. Véase AGI, Audiencia de Filipinas, 6, R. 3, N. 26. Cfr. "China en España...", op. cit.

${ }^{22}$ AGI, Patronato, 24, R. 37. Cfr. P. TORRES Y LANZAS (1926).Catálogo de los documentos relativos a las Islas Filipinas existentes en el Archivo de Indias de Sevilla. Tomo II. Barcelona: Compañía General de Tabacos de Filipinas,p. XLIX; M. OLLÉ (2002). op. cit., p. 84.
} 
"A vos el poderoso y muy estimado Rey de la China". Primera embajada regia de Felipe II con destino a la China de la dinastía Ming: origen, preparación y abandono

pacificaciones, en el Bosque de Segovia, el 13 de julio de $1573^{23}$.

Los descubridores por mar o tierra no se empachen en guerra ni conquista en ninguna manera ni ayudar a vnos indios contra otros ni se rebuerlban en questiones ni contiendas con los de la tierra por ninguna caussa ni razon que sea ni les hagan dagno ni mal alguno ni les tomen contra su voluntad cossa suya sino fuese por rescate o dándoselo ellos de su voluntad ${ }^{24}$.

Asimismo, por parte de Felipe II hallamos algunas referencias por las que nos consta su interés por los asuntos sínicos. El 15 de marzo de 1577, el Consejo de Indias avisó al rey de la llegada de informaciones de Nueva España, de las Filipinas y, también de China, por lo que el monarca comentó que "ha sido bien auisarme de todo esto, y lo de las descripciones me queda acá para verlo, en pudiendo"25. Además, Felipe II pidió a sus oficiales más relaciones escritas, relativas a China, por los miembros que habían participado en las expediciones castellanas con destino a aquel imperio oriental. Incluso reclamó la presencia del Padre Rada en la corte, pero este falleció en 1578 en el Archipiélago ${ }^{26}$. Ante la imposibilidad de que Martín de Rada cumpliera con encargo real, en 1576, el gobernador de las Filipinas, Francisco de Sande, envió a España al también agustino Francisco de Ortega ${ }^{27}$.

\footnotetext{
${ }^{23} \mathrm{M}^{\mathrm{a}} \mathrm{I}$. VIFORCOS MARINAS (1998). “China, una prolongación de la polémica sobre el Nuevo Mundo". Estudios Humanísticos. Geografia, Historia y arte, Número 20, pp. 57-78.

${ }^{24}$ M. CUESTA DOMINGO (1994). Normativa para descubrimientos y Ordenanzas del Bosque de Segovia. Madrid: Colegio Universitario de Segovia, p. 186.

${ }^{25}$ AGI, Indiferente General, 739, N. 14.

${ }^{26}$ M. OLLÉ (2002). op. cit., p. 86; C.L. de la VEGA Y DE LUQUE (1980). "Un proyecto utópico: la conquista de China por España: Continuación”. Boletín de la Asociación Española de Orientalistas, XVII, pp. 46-47.

${ }^{27}$ G. de SAN AGUSTÍN (1975). op. cit., p. 701; J. de MEDINA (1893). Historia de los sucesos de la Orden de N. Gran P. S. Agustín de estas Islas Filipinas, desde que se descubrieron y se poblaron por los españoles, con las noticias memorables. Manila: Tip. de Chofré y Comp., p. 121. Francisco de Ortega (-1601) era natural del pueblo castellano-manchego de Garci-Muñoz y profesó en el convento agustino de Toledo en 1564. En 1566 llegó a Nueva España, donde ejerció como confesor y predicador. Más tarde arribó a las Islas Filipinas y logró ser electo definidor tercero y prior de Manila. En el año de 1578 fue enviado a Castilla como procurador de su Orden por Filipinas. En 1580 Felipe II le envió como embajador ante el emperador chino. Aunque la embajada finalmente no se llevó a término, el Padre Ortega volvió con un grupo de misioneros a Manila en 1590. Fue nombrado primer obispo de la Nueva Cáceres, cuya gracia confirmó el Papa el 13 de septiembre de 1599. Francisco de Ortega murió en México en 1601
} 
Con la llegada del fray Francisco de Ortega, la propuesta de enviar una embajada oficial desde Castilla a China en nombre de Felipe II, tal y como lo había proyectado Diego de Herrera en 1574, pasó otra vez a la consideración del monarca y de sus consejeros. A la vez, para entender bien los intereses y las aspiraciones que tenía el rey Prudente sobre aquel imperio asiático, hay que tener en cuenta la complicada relación en aquel tiempo entre la monarquía hispana, la corte lusa y Roma. En efecto, fueron los portugueses quienes primero lograron entablar relaciones con China e instalarse a partir de los años cincuenta del siglo XVI en Macao. Más tarde, a solicitud del rey Don Sebastián, el 23 de enero de 1576, el Papa Gregorio XIII permitió la erección de la diócesis de Macao con jurisdicción sobre China. La diplomacia de Felipe II no se descuidó y se consiguió la creación de la primera sede episcopal de las Filipinas, en Manila, a través de una bula expedida en febrero de 1578: "Tamen cum multis jam annis milites carissimi in christo filij nostri Philippi Hispaniarum Regi catholici ad mare del Sur nuncupatum prevenissente, et quamplurinas insulas, philippinas nuncapatas, continenti Chinae adjacentes invenissent" ${ }^{28}$. Dos años después se emitían las cédulas reales que propiciaban el envío de la embajada a la corte de los Ming, precisamente en el momento clave del planteamiento de la unión de las coronas portuguesa y castellana. Es decir, poco a poco iba tomando cuerpo el sueño de la Monarchia Universalis ${ }^{29}$, que implicaba el acercamiento a China iniciado por los lusos.

Sea como fuese, la moción de la embajada regia a la China Ming se resolvió favorablemente. En consecuencia, el monarca nombró al propio Francisco de Ortega, al mencionado Juan González de Mendoza y a Jerónimo Marín ${ }^{30}$ como sus

sin poder llegar a su diócesis. En cuanto a la biografía de este agustino, véase G. de SAN AGUSTÍN (1975). op. cit., pp. 701-702; A.M. CASTRO (1954). Misioneros agustinos en el Extremo Oriente (1565-1780). Madrid: Instituto Santo Toribio de Mogrovejo, pp. 99-100.

${ }^{28}$ Colección de documentos inéditos relativos al descubrimiento, conquista y colonización de las posesiones españolas en América y Oceanía, sacados, en su mayor parte del Real Archivo de Indias. Tomo VIII. Madrid: Impr. de Bernaldo de Quirós. (1867), pp. 72-79.

${ }^{29}$ J. MARTÍNEZ MILLÁN (2003). "La crisis del 'partido castellano' y la transformación de la Monarquía Hispana en el cambio de reinado de Felipe II a Felipe III". Cuardernos de Historia Moderna, Anejo II, p. 12; J.M. HEADLEY (1995). "Spain's Asian Presence, 1565-1590: Structure and Aspirations". The Hispanic American Historical Review, Vol. 75, No. 4, p. 636. ${ }^{30}$ Jerónimo Marín (-1606) nació en la ciudad de México de padres nobles y conquistadores. Recibió el hábito en el convento agustino de México, donde profesó en 1556. En 1577 regresó desde el Archipiélago a Nueva España y fue electo prior del convento de Guadalajara de Jalisco. Más tarde acompañó al provincial de su Orden en las Filipinas, Andrés de Aguirre, en el viaje a Castilla. A partir del año 1584 en el que regresó a Nueva España, ocupó varios cargos 
embajadores ante la corte de Pekín, debiendo ser portadores de una misiva y algunos obsequios. Como veremos más adelante, en la carta dirigida al mandatario chino, Felipe II valoró positivamente los contactos chino-castellanos que se habían desarrollado entre las islas Filipinas y el imperio oriental, incluso expresó su gratitud por la buena acogida que habían tenido sus diplomáticos.

\section{LA PREPARACIÓN EN CASTILLA DE LA EMBAJADA REGIA A CHINA}

El 5 de marzo de 1580 el Consejo de Indias, habiendo recordado la propuesta entregada por Diego de Herrera, la expedición liderada por Martín de Rada a Fujian y otros contactos realizados desde Filipinas, aconsejó formalmente a Felipe II el envío de una embajada con cartas regias y regalos ${ }^{31}$. El monarca respondió de su puño y letra que "Está muy bien y se podrá hazer con que no se lleue lo que toca a armas, porque no se yncurra en las censuras de lleuarse a los enemigos" ${ }^{32}$. Unavez aprobado el proyecto, el 3 de junio de 1580, se expidieron una serie de reales cédulas dirigidas a los oficiales, tanto de Castilla como de las posesiones ultramarinas afectadas. En ellas, se hacía el reparto de tareas entre unos y otros en lo relativo a aquella expedición tan larga y complicada. En las misivas destinadas a Nueva España, el monarca, tan prudente como siempre, envió cartas a los dos virreyes que por entonces se encontraban en aquel territorio, ya que eran momento de traspaso de poder $^{33}$. En la carta enviada al virrey saliente, Martín Enríquez de Almansa, Felipe II presentó resumidamente la expedición que según él:

[...] que acá se a tomado de escrivir y enbiar vn presente al rey de la China, con çiertos religiosos de la Orden de Sant Agustín, para que pareçiéndoos, según lo que se entendiere,

eclesiásticos como prior, visitador y definidor. En 1606 murió en el convento de Tlayacapan, al Sur de México. Acerca de la biografía de Jerónimo Marín, véase G. de SAN AGUSTÍN (1975). op. cit., pp. 730-731; A.M. CASTRO (1954). op. cit., pp. 120-121.

${ }^{31}$ AGI, Indiferente General, 739, N. 264.

${ }^{32} \mathrm{AGI}$, Indiferente General, 739, N. 240.

${ }^{33}$ El cambio de los dos virreyes de Nueva España ocurrió en el año 1580. El virrey saliente, Martín Enríquez de Almansa y Ulloa (1510-1583), después de doce años al frente del virreinato de Nueva España, era nombrado como virrey del Perú, por lo que salió de Acapulco el 9 de diciembre de 1580 y llegó a El Callao en 1581. Para sucederle en México fue nombrado el IV conde de Coruña, Lorenzo Suárez de Mendoza (1518-1583), que tomó posesión de su cargo el 4 de octubre del mismo año. En las reales cédulas relativas a la embajada de China y expedidas conjuntamente el 3 de junio de 1580, se mencionaba repetidamente el nombramiento del conde de Coruña como nuevo virrey de Nueva España. 
del estado de las cosas de aquella tierra, que se deve efecturar, se haga y no de otra manera ${ }^{34}$.

En otra real cédula despachada en el mismo día y dirigida a los oficiales de la Casa de la Contratación de Sevilla, se aclaró lo relativo a la cuestión de los embajadores que "llevan fray Francisco de Ortega y fray Juan González de Mendoza, de la Orden de San Agustín" 35 . Cabe señalar que aunque en la corte ya se había decidido el envío de la embajada, desde los primeros momentos, la realización final de dicha misión dependía de la decisión de la autoridad de Nueva España.

Además, en otra real cédula dirigida a los oficiales de las Filipinas, Felipe II confirmó de nuevo la responsabilidad que los mandatarios novohispanos, y de manera muy especial su virrey, tenían en la organización de aquel viaje diplomático al imperio oriental, en el que había puesto tantas esperanzas:

porque para que se ordene, como más conbenga, lo havemos remitido al conde de Coruña, nuestro visorrey de la Nueva España, os mando que la ynstrucçón y orden que sobre ello os embiaré, la guardéis y cumpláis con toda preçisión, como el negoçio lo requiere, dando todo favor y ayuda y buen abiamiento a los dichos religiosos y personas que fueren con ellos con la diligençia y cuydado que se confía de vuestra persona, y muy en particular nos daréis aviso de la llegada destos religiosos y de las cosas que llevan y de su salida para aquel reyno ${ }^{36}$.

Aunque la corte había otorgado a los gobernantes de Nueva España el derecho de decidir si finalmente convenía emprender o no el viaje de la delegación desde la colonia americana, la preparación para esta expedición desde Castilla fue muy minuciosa. Un ejemplo de lo que se viene diciendo, referido en concreto a los preparativos en la Península, es el del encargo dado por el rey a varios oficiales, de que dispusiesen los obsequios que se debían llevar al mandatario chino. En primer lugar, la Casa de la Contratación de Sevilla fue el organismo designado para conseguir los regalos que debían enviarse:

${ }^{34}$ AGI, Audiencia de Filipinas, 339, L. II, F. 4rv. Cfr. I. RODRÍGUEZ RODRÍGUEZ (1976). op. cit., pp. 38-39.

${ }^{35}$ AGI, Audiencia de Filipinas, 339, L. II, F. 5rv.

${ }^{36}$ AGI, Audiencia de Filipinas, 339, L. II, F. 4v. Cfr. I. RODRÍGUEZ RODRÍGUEZ (1976). op. cit., pp. 40-41. 
Ya savéis como por otra nuestra cédula, fecha en Çorita a veinte y çinco de abrill próximeo pasado deste presente año, os embíamos a mandar que conprásedes y hiziésedes poner a punto las cossas contenidas en vna relaçión, que se os embió, firmada de Juan de Ledesma, nuestro secretario de cámara del gobierno en nuestro Consejo de las Indias, para enviar al rey de la China, con otras que para el mismo efecto se aprerçivían en nuestra corte y las tuviésedes a punto para entregarlas a la persona[... $]^{37}$.

Finalmente, el 27 de julio de 1580, el Consejo de Indias entregó una consulta relativa a los presentes mencionados y destinados al emperador chino por parte de Felipe II. Según habían planteado los oficiales del Consejo, los obsequios para el remoto imperio oriental se enviarían en un barco, haciendo escala en Nueva España y en las islas Filipinas . El Prudente así contestó sobre esta cuestión:

A Delado he ordenado que se haga luego vna carta mía para Gasca [el presidente del tribunal de la Casa de la Contratación de Sevilla, Gasca de Salazar ${ }^{38}$ ] en que se le diga que para proueer lo de la China tome quatro mill y quinientos ducados. que ay allí en Seuilla ${ }^{39}$.

Debido al tiempo que se necesitaba para organizar la cuestión de los regalos, el embajador Francisco de Ortega se embarcó rumbo a Nueva España con otros misioneros recién elegidos para las Filipinas, quedándose en Castilla Juan González de Mendoza con otros miembros de la misión para hacerse cargos de los obsequios que debían portar. El testimonio del propio fraile así lo manifiesta:
Allí me detuve solicitándolas algunos días y porque por ser muchas las que se habían de hacer y no era posible acabarse para el tiempo en que la partida de la flota estaba pregonada, el señor licenciado Gasca de Salazar, presidente de la Contratación de Sevilla y oidor del Consejo Real de las Indias, dio de ello cuenta a Su Mejestad, que estaba en Badajoz, ocupado en las cosas del reino de Portugal, para que diese el orden que fuese servido ${ }^{40}$.

\footnotetext{
${ }^{37}$ AGI, Audiencia de Filipinas, 339, L. II, F. 6. Cfr. Ibidem, pp. 43-44.

${ }^{38}$ P. TORRES Y LANZAS (1926). op. cit., p. LV.

${ }^{39}$ AGI, Indiferente General, 739, N. 264.

${ }^{40}$ J. GONZÁLEZ DE MENDOZA (1990). op. cit., p. 153.
} 
Según las cartas escritas por Juan González de Mendoza y dirigidas al rey Prudente, la embajada liderada por el agustino salió del puerto de Sanlúcar de Barrameda el 20 de febrero de 1581 portando la carta regia y regalos para el emperador de China, y "llegué a esta Nueva España con bueno, aunque largo viaje, a primero de junio, y luego subí a México con el presente, que por orden de V. A. se traya para el rey de la China"41.

En cuanto a los obsequios ${ }^{42}$, según el documento señalado, estos eran de ricos vestidos, aderezos para su real cámara, sillas de montar, armas y armaduras, seis piezas de terciopelo de seda de distintos colores, seis pipas de riquísimo vino añejo de Jerez, algunos relojes de valor, un retrato de Carlos V y otro de Felipe II, y una preciosa imagen de la Virgen ${ }^{43}$. Además de los regalos se enviaba a dos profesionales: "Porque para tener quenta con el adereço de çiertos rreloges y pinturas, que entre otras cosas embiamos al rrey de la China, tenenmos por bien que puedan yr allá Alonso Francisco, pintor, y Hernando de Guzmán, relogero"44.

Es más, según los relatos del Padre Mendoza, "puesto todo en orden, se me entregó

${ }^{41}$ AGI, Audiencia de Filipinas, 84. Cfr. I. RODRÍGUEZ RODRÍGUEZ (1981). op. cit., pp. 2931.

${ }^{42}$ En cuanto a la importancia de los obsequios diplomáticos y las multiples funciones de los regalos en la Edad Moderna, véase N.Z. DAVIS (2000). The Gift in Sixteenth-Century France. New York: Oxford University Press; M. MAUSS (2000). The Gift: The Form and Reason for Exchange in Archaic Societies. New York: Norton; A. LOOMBA (2009). "Of Gifts, Ambassadors, and Copy-cats: Diplomacy, Exchange, and Difference in Early Modern India". En Charry, B. y Shahani, G. (eds.). Emissaries in Early Modern Literature and Culture: Mediation, Transmission, Traffic, 1550-1700. Farnham: Ashgate, pp. 41-75.

${ }^{43}$ AGI, Audiencia de Filipinas, 339, F. 7rv. En cuanto a los obsequios destinados al emperador chino, en el Archivo General de Indias encontramos una serie de documentos que tratan de este asunto. Al principio, Juan González de Mendoza entregó una memoria a fin de preponer determinados regalos. El Consejo de Indias denegó parcialmente las peticiones del Padre y por fin aprobó una lista de "las cosas que Su Magestad puede embiar al Rey de Tai bin [dinastía Ming]". Véase AGI, Patronato, 25, Ramo 3; Colección de documentos inéditos relativos al descubrimiento, conquista y organización de las antiguas posesiones españolas de ultramar. TOMO XVII. Madrid: Esta. Tip. Sucesores de Rivadeneyra. (1925), p. 149, y el TOMO XVIII de la misma obra, p. 220; P. TORRES Y LANZAS (1926). op. cit., p. LV.

${ }^{44}$ AGI, Audiencia de Filipinas, 339, L. II, F. 5rv. Cfr. I. RODRÍGUEZ RODRÍGUEZ (1976). op. cit., pp. 41-43. 
la carta de Su Majestad [para el rey de China]"45. Esta misiva ${ }^{46}$ se despachó el 11 de junio de 1580 en Badajoz, pero se había escrito unos días antes, teniendo en cuenta que el 8 de junio del mismo año, Felipe II respondió al Consejo de Indias: La carta para el rey de la China se hizo en la forma que veréis por la copia que va aqui[...]"47.

Merece la pena señalar primero que el tono general de la misiva regia destaca por estar escrita en un tono bastante modesto e incluso de humildad ${ }^{48}$. Al principio de la carta, tras relacionarse los títulos que tenía, como era privativo, Felipe II puso de manifiesto los conocimientos que tenía sobre el imperio oriental y el origen de los mismos:
a uos el poderoso y muy estimado rey de la China como aquél a quien deseamos el berdadero y entero bien salud y prosperidad, con acreçentamyento de buenos deseos, hauiendo entendido por auiso de mis gouernadores de las yslas Philipinas y relaçión de algunos religiosos que dellas han benido la pruden[ci]a y justi[ci]a con que gouernáis ese gran reyno y el buen acogimiento y tratamyento que vuestros vasallos han hecho a los nuestros en los puertos y lugares donde han llegado y olgado mucho de lo vno y de lo otro, os lo he querido significar y agradeçer por ésta[... $]^{49}$.

Siendo un rey cristiano, Felipe II estaba procurando la amistad con un rey pagano, pero en un contexto religioso concreto, en el que el monarca español revelaba la superioridad del cristianismo:

[...] me será muy agradable vuestra amistad y comunicaçión, encaminándola prinçíp[a]lmente a la gloria y onrra del berdadero Dios criador del çielo y de la tierra y de todas las criaturas del mundo visibles y ynbisibles,

\footnotetext{
45 J. GONZÁLEZ DE MENDOZA (1990). op. cit., p. 153.

${ }^{46}$ AGI, Patronato, 24, R. 51. Cfr. I. RODRÍGUEZ RODRÍGUEZ (1976). op. cit., pp. 44-46; C. HSU (2004). op. cit., pp. 194-209; “China en España...”.op. cit.

${ }^{47}$ AGI, Indiferente General, 739, N. 262.

${ }^{48}$ Acerca de la carta escrita por Felipe II y dirigida al emperador chino, tenemos un estudio excelente para ampliar las visiones y profundizar los conocimientos sobre este curioso e importante documento. C.Y. HSU (2010). "Writing on behalf of a Christian Empire: Gifts, Dissimulation, and Politics in the Letter of Philip II of Spain to Wanli of China". Hispanic Review: summer, pp. 323-344.

${ }^{49}$ AGI, Patronato, 24, R. 51. [op. cit.].
} 
salua[dor] y glorificador de los hombres que con verdadero conoçimiento creen en él y obedezen su santa ley de[c]larada por su palabra confirmada con sus diuinas señales $[\ldots]^{50}$.

Para la salvación de los chinos, el rey Prudente presentaba a los agustinos ante el emperador chino, de la siguiente manera:

[...] como os lo darán a entender en particular los religiosos

de la Orden de Sant Augustín que ésta lleuan de quien

seréis informado de la ley evangélica y cosas de nuestra

santa fee católica[...] os pido y ruego encareçidamente reçivá[is] y oyáis begninamente a estos religiosos que como ministros de Dios[... $]^{51}$.

A continuación, en la misiva dirigida al mandatario de un país no cristiano, Felipe II incluso exponía las ventajas que suponía la conversión:

[...]de mano del mismo Dios tantos beneficios y mercedes y hauiéndoos dotado de tan buen juiçio y entendimiento conosçéreis que os enbío el bien y riqueza del çielo que por este medio ganaréis en cuyo respecto es nada toda la grandeza y monarchía de la tierra y seguirse a de aquí hazer estable nuestra amistad $[\ldots]^{52}$.

Solo al final de la carta, el monarca español aludió a los obsequios, "que os inuío algunas cosas de las que ay y se vsan en estos nuestros rey[n]os por sinificaçión de la buena amistad" 53 .

\section{PROBLEMAS ENCONTRADOS Y ABANDONO DEFINITIVO A LA EMBAJADA}

La llegada, tanto de los embajadores como de los obsequios y cartas dirigidas al emperador de la China, desencadenó en Nueva España cálidos aplausos, profundas dudas y airadas protestas sobre la oportunidad de la embajada. En cuanto a los argumentos positivos hay que señalar, de acuerdo con los relatos del embajador Juan González de Mendoza, los siguientes: “[...] y subi luego a México con el presente, el

\footnotetext{
${ }^{50}$ Ibidem.

${ }^{51}$ Ibídem.

${ }^{52}$ Ibidem.

${ }^{53}$ Ibidem .
} 
"A vos el poderoso y muy estimado Rey de la China". Primera embajada regia de Felipe II con destino a la China de la dinastía Ming: origen, preparación y abandono

qual fue recibido con un muy común aplauso de todos, asi por ver el zelo de su Magestad en obra tan cathólica y piadosa, como por el provecho que a todos se les avía de seguir de la contratación" 54 .

Pero, por otra parte, también otro de los embajadores nombrados para esta embajada, el también agustino Francisco de Ortega informaba al monarca de las vacilaciones e indecisiones que existían en su momento en Nueva España sobre la expedición con destino a China. El fraile se sintió inquieto por la larga espera del envío de la embajada y escribió al monarca sobre la voluntad real ${ }^{55}$.

Poco después de recibir a los embajadores y los regalos para el emperador oriental, el virrey de Nueva España, conde de Coruña, empezó a tratar este asunto. Habiendo leído atentamente la carta escrita por Lorenzo Suárez de Mendoza, dirigida a Felipe II el 20 de octubre de $1581^{56}$, se aprecia la prudencia e incluso la neutralidad que el nuevo virrey mostraba en lo que concierne a la embajada al emperador chino. El conde de Coruña, pidió opiniones a los que conocían bien China, entre ellos, al virrey saliente de Nueva España, Martín Enríquez de Almansa; al exgobernador de lasFilipinas, Francisco de Sande ${ }^{57}$; a los agustinos, Jerónimo Marín y Andrés de Aguirre ${ }^{58}$; y por último a los jesuitas que acababan de llegar a las Filipinas en 1581, Antonio de Sedeño y Alonso Sánchez ${ }^{59}$. Es más, el virrey envió a Felipe II tanto las respuestas positivas como las negativas relativas a esta misión diplomática y especialmente al envío de los presentes.A este respecto, el antiguo gobernador de las Filipinas, el doctor Francisco de Sande, afirmó: "Me ha mandado [que] diga mi parecer sobre si convenga que Su Magestad enbie presente al rey de la China sobre esto me preguntó el conde de Coruña

\footnotetext{
${ }^{54}$ AGI, Audiencia de México, 285. Cfr. I. RODRÍGUEZ RODRÍGUEZ (1981). op. cit., pp. 3134.

55 AGI, Indiferente General, 739, N. 264. Y AGI, Audiencia de Filipinas, 84. Ibídem, pp. 4346.

${ }^{56}$ AGI, Indiferente General, 739, N. 264.

${ }^{57}$ Recordemos que precisamente Francisco de Sande había informado en algunas ocasiones al virrey Almansa sobre cuestiones de China. AGI, Audiencia de Filipinas, 6, R. 3, N. 25 y 37.

${ }^{58}$ Precisamente este fraile organizaría la conversión del los chinos que llegaban a Filipinas, estableciéndose un conflicto con el prelado de la diócesis, en 1584. AGI, Audiencia de Filipinas, 79, N. 14.

${ }^{59}$ En cuanto a la llegada de los primeros jesuitas en las Filipinas, véase M. OLLÉ RODRÍGUEZ (1998). Estrategias filipinas respecto a China: Alonso Sánchez y Domingo Salazar en la empresa de China (1581-1593). Barcelona: Tesis doctoral defendida en la Universidad Pompeu Fabra; y F. COLÍN (1900-1902). op. cit. I, pp. 161-167.
} 
por orden de su Magestad[...]que no se llevase ${ }^{\prime 60}$. A lo largo de la carta, expuso algunas de sus razones, que coinciden con las objeciones que presentaremos más adelante. Además, el mandatario novohispano convocó una junta para discutir las posibilidades y dificultades de dicha embajada ${ }^{61}$. A este respecto, disponemos de un escrito del embajador Francisco de Ortega, que contestó a todas las objeciones que había propuesto la junta, que fueron $\operatorname{diez}^{62}$ :

1. La primera, que no recibiría el presente el rey chino, y no lo resçibiendo, que sería gastar tiempo y dinero en balde;

2. La segunda objeción era que no reçibiendo el rey chino el presente y enbaxada, es menoscabo y afrenta de $V$. Magestad;

3. La tercera objeción decía que ban en gran riesgo y peligro de muerte o cárçel perpetua los que llebaren la embajada, $y$, por consiguiente, de perderse todo lo que $\mathrm{Su}$ Magestad enbia, porque diçen que lo tomarán y robarán;

4. La cuarta objeción era que ya que lo reçiba lo estimara en poco el rey chino, porque diçen que allá tiene él otras cossas más ricas y mejores;

5. La quinta objectión, que V. Magestad le abía de embiar un presente de gran valor, siendo el chino tan rico y poderoso rey, para que por el presente entendiera el gran poder y riqueça de V. Magestad;

\footnotetext{
${ }^{60}$ AGI, Indiferente General, 739, N. 264.

${ }^{61}$ Sabemos la existencia de la junta gracias a los relatos del Padre Mendoza, según él, "el virrey había hecho de los más grandes hombres de todo el reino acerca de la prosecución de la embajada". Véase J. GONZÁLEZ DE MENDOZA (1990). op.cit., p. 154.

${ }^{62}$ AGI, Indiferente General, 749, N. 55. Acerca de las objeciones que vamos a citar más adelante, véase "Respuesta que dio Fr. Francisco de Ortega, de la Orden de san Agustín, a las objeciones que se le hacían para suspender la prosecución de lo del presente para el rey de China”, cfr. I. RODRÍGUEZ RODRÍGUEZ (1981). op. cit., pp. 71-92. Cabe destacar que este documento se mantuvo durante bastante tiempo desconocido, hasta que Leandro Rodríguez lo publicara en 1979 bajo el título "Objeciones y respuestas a un proyecto de embajada a China (s. XVI)". Missionalia Hispanica, Número 83, pp. 249-262.En el documento original, no encontramos la fecha de la elaboración. Según los contenidos del escrito, podemos deducir que fue escrito aproximadamente en torno a 1582.
} 
"A vos el poderoso y muy estimado Rey de la China". Primera embajada regia de Felipe II con destino a la China de la dinastía Ming: origen, preparación y abandono

6. La sexta objectión es que es menester llevar gran cantidad de dinero para dar a los virreyes y governadores por donde an de pasar hasta llegar donde está el rey;

7. La séptima objeción decía que los intérpretes que an de llevar no tendrán fidelidad, y ques menester darles mucho dinero para llevarlos contentos;

8. La octaba objectión exponía que no ay para qué llebar cavallos, ni açémilas, porque allá ay muchos, y que a tierras tan remotas no se podrán llevar, y si fueren, que llegarán muy flacos;

9. También ponen objectión en deçir que ya que los cavallos lleguen a la çiudad de menila, que no se podrán llevar de allí a lá, porque diçen que ay muchos araçifes y baxios en la costa, por lo qual no podrán yr naos nuestras, y que aunque puedan yr, que no ay pilotos que sepan la navegaçión para guardarse de los baxios y para entrar en las barras de los puertos;

10. La décima objectión concluía que ya que no aya los inconvinientes ariba dichos, que será menester gran cantidad de dinero para gastar en la china en yr desde el puerto hasta donde está el rey, y para gastar allá, y en bolver a traer la respuesta a $V$. Magestad.

El Padre Ortega refutó cada objeción y finalmente concluyó que había que continuar con la embajada hasta China, ya que consideraba que "en mandar $V$. Magestad proseguir esta jornada se aventura a perder poco[...] y se aventura a ganar mucho"63.

A pesar de todo lo arriba señalado, al final prevaleció el voto en contra de la expedición, aunque el padre Ortega seguiría insistiendo, en 1591, en la necesidad de la conversión del imperio chino ${ }^{64}$. Esta es la constatación que se lee en una crónica de la Orden de San Agustín en Nueva España, que se publicó en 1624 por el Fray Juan de Grijalva:

${ }^{63}$ Ibídem.

${ }^{64}$ AGI, Audiencia de Filipinas, 79, N. 22. Hasta tal punto se había implicado el P. ortega en los asuntos chinos, que su propio criado era un natural de Cantón, al que se denominaba como Sebastián Pereda. AGI, Contratación 5253, N. 1, R. 21. 
Pues aumentar el presente a medida de la jactancia del chino o de su codicia, no parece que convenía, pues su amistad era de ninguna consecuencia para conservación de las islas [Filipinas], y así parecía mucho el gasto sin que dello se siguiese utilidad alguna. En estos dos puntos discurrió con tan grande eficacia y con tan buenas razones, que se tomó por entonces resolución, de que se detuviese la embajada en esta tierra hasta dar aviso a su Majestad de todo, como se hizo ${ }^{65}$.

También y según las fuentes nos indican, fue el otro embajador designado, Juan Gónzalez de Mendoza, el que comunicó a Felipe II su opinión en relación a que se detuviera la misión enviada desde Castilla:

[...] a V. Magestad suplico [...] mande se suspenda la tal resolución hasta que yo y la relaçión que digo del doctor Sandi y virrey llegue, pues a de ser con tanta brevedad, por la qual se podrá ver claramente lo que ay de verdad y dificultad en la jornada, y los medios por donde se pueda mejor conseguir el muy cathólico fin que V. Magestad pretende $^{66}$.

Es más, el Padre Mendoza autorizado por el virrey de Nueva España desembarcó en 1582 en Lisboa con objeto de informar al rey en aquella ciudad:

Llegué, prosiguiendo el orden que llevaba, al reino de México, donde ofreciéndose cierto inconveniente, que Su Majestad en el orden que había dado para la jornada mandaba se advirtiese, y siendo necesario darle noticia de él, antes de pasar adelante, pareció bien al virrey de aquel reino, que era el conde de Coruña, volviese a Lisboa, donde $\mathrm{Su}$ Majestad estaba, a darle cuenta de ciertas dificultades que se habían hallado $[\ldots]^{67}$.

El 19 de mayo de 1582, el Consejo de Indias planteó una consulta con el fin de suspender el envío de la embajada a la China de Ming y de ordenar al virrey a vender

65 J. de GRIJALVA (1985). Crónica de la Orden de N.P.S Agustín en las provincias de la Nueva España. México, D. F., p. 351.

${ }^{66}$ AGI, Audiencia de México, 285. Cfr. I. RODRÍGUEZ RODRÍGUEZ (1981). op. cit., pp. $42-$ 43.

${ }^{67}$ J. GONZÁLEZ DE MENDOZA (1990). op. cit., p. 154. 
los regalos preparados. Aunque en la misma consulta se entregó también el citado documento elaborado por Francisco de Ortega, en el cual el fraile dio contestación a las objeciones sobre la misión diplomática. El veredicto del monarca fue breve y claro: "Esta bien y va firmada" 68 .

La primera embajada mandada por Felipe II con destino a China quedó así abandonada, y los obsequios dirigidos al emperador del imperio oriental fueron vendidos en Nueva España en el mismo año ${ }^{69}$. En consecuencia, tampoco tuvo sentido cumplir con las instrucciones que se habían dado para el virrey novohispano "para la compra de çiertas cosas, que de ay se han de llevar al rey de la China"70.

\section{CONCLUSIÓN}

A modo de una breve conclusión de lo que en estas páginas se ha escrito, queremos señalar varias cuestiones.

La primera, está relacionada con el origen de la expedición, que situamos en unos primeros contactos informales establecidos por los oficiales castellanos en Filipinas, que se hicieron sin autorización real, aunque se informó de ellos puntualmente al monarca por diferentes vías.

La segunda es una cuestión que nos parece interesante resaltar, como es la relacionada con la estructura de la toma de decisiones. Dos circuitos decisivos quedan claramente establecidos: uno que consideramos más oficial, o que está mejor establecido: corte-virreinato de Nueva España- Filipinas, -ida y vuelta. No obstante, esta forma preponderante de establecer la comunicación, no exceptuaba la posibilidad

\footnotetext{
${ }^{68}$ AGI, Indiferente General, 740, N. 55.

${ }^{69}$ El virrey de Nueva España recibió las instrucciones a través de una real cédula despachada desde Castilla el 27 de mayo de 1582, para que se vendieran los regalos destinados al emperador de China en su virreinato. Acerca de esta información, véase P. TORRES Y LANZAS (1926). op. cit., p. LVII.
}

${ }^{70}$ AGI, Audiencia de Filipinas, 339, L. II, F. 4. Cfr. I. RODRÍGUEZ RODRÍGUEZ (1976). op. cit., pp. 40. Además de esta real cédula, el Consejo de Indias despachó al virrey de Nueva España para que las autoridades de aquel virreinato prepararan los siguientes objetos para regalar al rey de la China: Lo que se ordenó que se comprase en la Nueve España, fué 12 alcones, otros tantos cavallos como se llevaban jaezes, con sus tellizes de las armas reales, seis acémilas, en que vayan los cofres del presente con sus repeosteros de terciopelo carmesí con las armas reales[...]. Acerca de este documento, véase Colección de documentos inéditos relativos al descubrimiento, conquista y organización de las antiguas posesiones españolas de ultramar. (1925). op. cit., p. 104. 
menos frecuente de establecer un contacto directo Filipinas-corte y viceversa. En cada uno de estos itinerarios primaba intereses diferentes.

Como hemos manifestado en los capítulos anteriores, la primera embajada regia mandada por Felipe II quedó finalmente suspendida. Sin embargo, a través de los detalles recuperados a partir de un amplio abanico de escritos elaborados en el siglo XVI, a fin de realizar dicha misión, podemos observar la estrecha colaboración existente entre las diferentes instituciones y los oficiales dentro de todo el imperio gobernado por Felipe II. Una vez que en la corte se dieron las instrucciones, los implicados comenzaron a asumir sus propias responsabilidades a la vez que informaban al monarca del desarrollo de la tarea.

Es más, cabe señalar que en el siglo XVI, entre el mundo hispano y el chino, se crearon múltiples contactos directos. Además, los castellanos contaban con amplísimos conocimientos sobre el imperio oriental y siempre intentaron encontrar oportunidades para introducirse en él por razones políticas, religiosas y económicas. A pesar de los constantes proyectos bélicos que se propusieron continuamente por sus oficiales, Felipe II prefirió optar por la vía pacífica para iniciar la relación oficial con aquel gran imperio.

Finalmente, merece la pena destacar que la estrategia pacífica de Felipe II con China no logró calmar el entusiasmo desbordado de aquel puñado de hombres de las Filipinas, en lo que concierne a la conquista de aquel imperio oriental. Como la embajada regia no se efectuó, los castellanos desde el Archipiélago seguían insistiendo y proponiendo a su monarca proyectos bélicos contra la dinastía Ming. En las juntas celebradas en las Filipinas durante 1581 y 1586, las autoridades políticas y eclesiásticas del archipiélago filipino, además de debatirla legitimidad y la viabilidad de la colonia, reconocieron la importancia que tenía la conquista de China para el mantenimiento de las Filipinas y para la expansión misionera. En consecuencia, entre 1587 y 1588,el jesuita Alonso Sánchez logró hacer llegar al monarca el proyecto bélico sobre China; pero Felipe II, de nuevo, desautorizó la utilización de la fuerza ${ }^{71}$.

${ }^{71}$ J. GAYO Y ARGAÓN (1950). op. cit., p. 147. Acerca de los proyectos de la conquista de China propuestos especialmente desde las Filipinas durante el reinado de Felipe II, véase M. OLLÉ RODRÍGUEZ (1998). op. cit. 
"A vos el poderoso y muy estimado Rey de la China". Primera embajada regia de Felipe II con destino a la China de la dinastía Ming: origen, preparación y abandono

\section{BIBLIOGRAFÍA}

Colección de documentos inéditos relativos al descubrimiento, conquista y colonización de las posesiones españolas en América y Oceanía, sacados, en su mayor parte del Real Archivo de Indias. Tomo VIII. Madrid: Impr. de Bernaldo de Quirós. 1867.

Colección de documentos inéditos relativos al descubrimiento, conquista y organización de las antiguas posesiones españolas de ultramar. Tomo núm. 3., II De las islas Filipinas, Madrid: Estab. Tip. Sucesores de Rivadeneyra, 1887.

Colección de documentos inéditos relativos al descubrimiento, conquista y organización de las antiguas posesiones españolas de ultramar. TOMO XVII. Madrid: Esta. Tip. Sucesores de Rivadeneyra. 1925.

"China en España. Elaboración de un corpus digitalizado de documentos españoles sobre China de 1555 a 1900" por la Universitat Pompeu Fabra, $<$ https://www.upf.edu/asia/projectes/che/principal.htm $>$ [Consultado: 28-12-2015].

CASTRO, A. M. (1954). Misioneros agustinos en el Extremo Oriente (1565-1780). Madrid: Instituto Santo Toribio de Mogrovejo.

CERVERA, J. A. (2013). Tras el sueño de China: Agustinos y dominicos en Asia Oriental a finales del siglo XVI. Madrid: Plaza y Valdés.

COLÍN, F. (1900-1902). Labor evangélica, ministerios apostólicos de los obreros de la Compañia de Iesvs, fvndacion, y progressos de su provincia en las islas Filipinas. II. Barcelona: Imp. y Lit. de Henrich.

CUESTA DOMINGO, M. (1994). Normativa para descubrimientos y Ordenanzas del Bosque de Segovia. Madrid: Colegio Universitario de Segovia.

DAVIS, N.Z. (2000). The Gift in Sixteenth-Century France. New York: Oxford University Press.

DÍAZ-TRECHUELO, L. (2001). Filipinas. La gran desconocida (1565-1898). Pamplona: EUNSA.

GALENDE, P.G. (1980). Apologia pro filipinos: the quixotic life and chivalric adventures of Fray Martin de Rada, OSA, in defense of the early filipinos. Manila: Salesiana Publishers.

GARCÍA-ABÁSOLO, A. (2012). Murallas de piedra y cañones de seda: chinos en el Imperio español (siglos XVI-XVIII). Córdoba: Servicio de Publicaciones, Universidad de Córdoba, D. L. 
GAYO Y ARGAÓN, J. (1950). Ideas jurídico-teológicas de los religiosos de Filipinas en el siglo XVI sobre la conquista de las islas. Manila: Universidad de Santo Tomás.

GONZÁLEZ DE MENDOZA, J. (1944). Historia de las cosas mas notables, ritos y costumbres del Gran Reino de la China. Madrid: Aguilar.

(1990). Historia del Gran Reino de la China. Madrid: Miraguano; Polifemo.

GRIJALVA, J. de (1985). Crónica de la Orden de N.P.S Agustín en las provincias de la Nueva España. México, D. F.: Porrúa.

HEADLEY, J. M. (1995). "Spain's Asian Presence, 1565-1590: Structure and Aspirations". The Hispanic American Historical Review, Vol. 75, No. 4, p. 623-646.

HEREDIA HERRERA, A. (1972). Catálogo de las consultas del Consejo de Indias.Tomo I (1529-1591). Madrid: Dirección General de Archivos y Bibliotecas.

HIDALGO NUCHERA, P. (1995). Encomienda, tributo y trabajo en Filipinas (15701608). Madrid: Universidad Autónoma y Polifemo.

HSU, C. (2004). "Dos cartas de Felipe II al emperador de China". eHumanista: Journal of Iberian studies. Vol. 4, pp. 194-209.

(2010). "Writing on behalf of a Christian Empire: Gifts, Dissimulation, and Politics in the Letter of Philip II of Spain to Wanli of China". Hispanic Review: summer, pp. 323-344.

LOOMBA, A. (2009). “Of Gifts, Ambassadors, and Copy-cats: Diplomacy, Exchange, and Difference in Early Modern India". En Charry, B. y Shahani, G. (eds.). Emissaries in Early Modern Literature and Culture: Mediation, Transmission, Traffic, 1550-1700. Farnham: Ashgate, pp. 41-75.

MARTÍNEZ MILLÁN, J. (2003). "La crisis del 'partido castellano' y la transformación de la Monarquía Hispana en el cambio de reinado de Felipe II a Felipe III". Cuardernos de Historia Moderna, Anejo II, pp. 11-38.

MAUSS, M. (2000). The Gift: The Form and Reason for Exchange in Archaic Societies. New York: Norton.

MEDINA, J. de (1893). Historia de los sucesos de la Orden de N. Gran P. S. Agustín de estas Islas Filipinas, desde que se descubrieron y se poblaron por los españoles, con las noticias memorables. Manila: Tip. de Chofré y Comp. 
"A vos el poderoso y muy estimado Rey de la China". Primera embajada regia de Felipe II con destino a la China de la dinastía Ming: origen, preparación y abandono

MERINO, M. (1944). "Semblanzas misioneras: Fr. Martín de Rada, Agustino". Missionalia Hispanica, I, pp. 167-212.

NUCHERA HIDALGO, P. (1993). Las polémicas iglesias-estado en las Filipinas. Córdoba: Universidad de Córdoba.

OLLÉ, M. (1998). Estrategias filipinas respecto a China: Alonso Sánchez y Domingo Salazar en la empresa de China (1581-1593). Barcelona: Tesis doctoral defendida en la Universidad Pompeu Fabra.

(2002). La empresa de China: De la Armada Invencible al Galeón de Manila. Barcelona: Acantilado.

OSTOLAZA, M. I. (2006). "Fray Martín de Rada, evangelizador, cosmógrafo y embajador en China". Huarte de San Juan. Geografía e Historia, Número 13, pp. 177-198.

RODRÍGUEZ, L. (1979). "Objeciones y respuestas a un proyecto de embajada a China (s. XVI)". Missionalia Hispanica, Número 83, pp. 249-262.

RODRÍGUEZ RODRÍGUEZ, I. (1965). Historia de la provincia agustiniana del Santísimo Nombre de Jesús d Filipinas. Vol. I. Manila: Catholic Trade School. (1976). Historia de la provincia agustiniana del Santísimo Nombre de Jesús de Filipinas. Vol. X. Valladolid: Estudio Agustiniano, pp. 44-46.

(1978). Historia de la provincia agustiniana del Santísimo Nombre de Jesús de Filipinas. Vol. XIV. Manila: Convento de San Agustín.

(1981). Historia de la provincia agustiniana del Santísimo Nombre de Jesús de Filipinas. Vol. XV. Manila: Convento de San Agustín.

SAN AGUSTÍN, G. de (1975). Conquista de las Islas Filipinas (1565-1615). Madrid: CSIC.

TORRES Y LANZAS, P. (1926). Catálogo de los documentos relativos a las Islas Filipinas existentes en el Archivo de Indias de Sevilla. Tomo II. Barcelona: Compañía General de Tabacos de Filipinas.

VEGA Y DE LUQUE, C.L. de la (1980). "Un proyecto utópico: la conquista de China por España: Continuación". Boletín de la Asociación Española de Orientalistas, XVII, pp. 46-47.

VIFORCOS, M.I. (1998). "Semblanza de fray Juan González de Mendoza (OSA), embajador de Felipe II a China y obispo de Popayán”. La Ciudad de Dios: revista agustiniana, Número 221, pp. 729-758. 
(1998). "China, una prolongación de la polémica sobre el Nuevo Mundo". Estudios Humanísticos. Geografia, Historia y arte, Número 20, pp. 57-78. 
Sección IV: RESEÑAS Y NOTICIAS BIBLIOGRÁFICAS 

GARCÍA HURTADO, Manuel-Reyes y REY CASTELAO, Ofelia (eds.), Fronteras de agua. Las ciudades portuarias y su universo cultural (siglos XIVXXI), Santiago de Compostela: Universidade de Santiago de Compostela, 2016, 570 p. ISBN: 978-84-16533-87-9.

Las ciudades portuarias, en general, y las atlánticas en particular han gozado de un innegable interés por parte de la historiografía en las últimas décadas. El dinamismo vivido por estos espacios de un lado y otro del océano a partir, sobre todo, del proceso de expansión marítima auspiciado por las potencias europeas en los albores de la Modernidad, los convirtió en motores de desarrollo económico y de dinamismo cultural. Los grandes puertos atlánticos fueron centros de innovación y transformación, por lo que el estudio de sus modelos, su articulación o las transferencias entre los diferentes puntos de la redportuaria debe ocupar un lugar preferente en el análisis histórico.La cuestión es lo suficientemente compleja como para que sea necesario afrontar este reto desde una perspectiva interdisciplinar y transversal. Ese es el enfoque con el que se aborda dicha realidad en el libro "Fronteras de agua", publicado por la Universidad de Santiago de Compostela, bajo la edición de dos consumados expertos en este campo: los profesores Manuel-Reyes García Hurtado, de la Universidad de A Coruña, y Ofelia Rey Castelao, de la Universidad de Santiago de Compostela.

El libro, que recoge un total de treinta y cuatro trabajos firmados por investigadores de diferentes universidades europeas y americanas, toma como eje vertebrador el estudio del universo cultural de los puertos atlánticos. Y lo hace desarrollando su análisis desde ese necesario prisma multidisciplinar del que hacíamos referencia. Nos encontramos en la relación de autores a medievalistas, modernistas, americanistas, antropólogos, historiadores del arte, etc. Asimismo se opta por un análisis desde la larga duración, arrancando en los siglos medievales y llegando hasta nuestros días, si bien es cierto que el grueso de los estudios se focaliza en los siglos de la Edad Moderna, período en el que nace y se consolida la globalización de los intercambios al socaire de la apertura de las rutas atlánticas.

Como señalan los propios editores en la presentación de la obra, el objetivo general que se pretende parece a primera vista sencillo pero su materialización resulta ciertamente compleja, habida cuenta de las múltiples facetas que engloba. En este sentido, los trabajos contenidos en el libro pueden agruparse en tres grandes ejes temáticos. El primero, con un abundante número de estudios, nos ofrece una interesante visión sobre la diversidad de comportamientos existentes en los ámbitos portuarios. De este modo, se analizan, entre otros aspectos, diferentes sectores socio- 
laborales vinculados al mar, grupos étnicos, colectivos de inmigrantes o de transeúntes, agrupaciones de carácter religioso o la importancia del sector femenino en las economías marineras. El segundo gran bloque se centra en la concepción, organización y construcción de los puertos. Algunas aportaciones se orientanal estudio de su gobierno, otras a las infraestructuras, a los mecanismos de control ideológico, a los sentimientos religiosos, al cosmopolitismo, etc. Finalmente, el tercer bloque, el más reducido en cuanto a número de aportaciones, se adentra en el estudio de las rutas marítimas durante el período objeto de estudio desde la perspectiva de su representación gráfica y su análisis.

En resumidas cuentas, estamos ante una muy recomendable obra que abre nuevas perspectivas y debates en un tema ciertamente atractivo para los estudiosos y que, sin duda, propiciará nuevos avances en los próximos años.

Maria José Pérez Álvarez - Universidad de León
maria-jose.perez@unileon.es

APAOLAZA LLORENTE, Dorleta, Los bandos de buen gobierno en Cuba. La norma y la práctica (1730-1830), Vitoria: Servicio Editorial de la Universidad del País Vasco, 2016, 719 págs., ISBN: 978-84-9082-400-9.

Esta voluminosa obra aborda un tema de los menos estudiados dentro de las reformas borbónicas americanas, como son los bandos de buen gobierno. Incluso en la isla de Cuba, a la que se dedica el libro, tan solo se han investigado los referentes al gobernador Luis de las Casas, los del conde de Ricla y los de José Manuel Ezpeleta; estos últimos, precisamente, por quien prologa esta obra, el Dr. Juan Bosco Amores Carredano. Precisamente la misma autora nos hace una interesante reflexión bibliográfica en la introducción, que se completa con una amplia bibliografía, que nos ofrece entre las páginas 698-719.

A lo largo del extenso libro se nos pone de manifiesto la importancia de los bandos de buen gobierno en la regulación de la vida de las ciudades y, en consecuencia, la que también tenían para la organización de las mismas y el desarrollo de la vida diría, sin que se entrara en conflicto con las normativas locales.

La autora aborda en este trabajo el conjunto completo de todos los bandos que se dieron para la isla desde 1734 hasta 1828 . Como no podía ser de otra forma, en un 
principio hace hincapié en todo lo que corresponde al marco teórico de la ciencia de la policía durante la Ilustración, para luego introducirnos en todo lo que tuvo que ver con este tipo de bandos en la América española.

Pasa luego a abordar de lleno en la temática central. Comienza por el estudio de los bandos de buen gobierno en La Habana, ciudad para la que se dictaron once de ellos, que la autora va desglosando y comparando a lo largo del texto, de una manera muy precisa. Por tanto, pone de manifiesto lo que es común a todos ellos: intitulación, cláusula introductoria, cláusulas dispositivas y cláusula final; a partir del siglo XIX se considera igualmente un último apartado de anexos. De especial interés en lo tratado es el reglamento de policía de 1763, por el que la capital cubana quedó organizada en barrios y cuarteles, así como fue especialmente relevante lacreación de la figura de los comisarios de barrio.

Es en el capítulo sexto, en el que pasan a tratarse aspectos más concretos de esos 11 bandos, como era la cuestión de las armas, la vigilancia de la ciudad, los vagos,la movilidad..., es decir, de todo aquello que tenía que ver con el control social. Precisamente en este sentido era de especial interés lo que correspondía a la movilidad, que según la autora no fue más que una quimera, pero que se planteaba casi de forma obsesiva

Es interesante el que la autora se haya detenido especialmente en los grupos sociales que las autoridades consideraban más inclinadas al delito. Estos eran fundamentalmente las gentes de color, los vagos, los soldados licenciados y los fugitivos. Curiosamente, en paralelo, se hace una consideración sobre los hijos de los poderosos de la sociedad habanera, a los que se consideraba como las víctimas más propicias para el engaño, por parte de todos esos grupos "marginales". La sociedad civil sería la que de una forma más llamativa se interesó por el mantenimiento del orden, en la que medida en que era evidente a todas luces la falta de personal cualificado; en consecuencia, los vecinos y las propias familias actuaban como mecanismos de control, aunque los primeros eran más proclives a hacer denuncias que a ejercer una verdadera colaboración.

Se tratan luego, en el capítulo 5, de forma concreta, los bandos de buen gobierno de La Habana, ciudad para la que, como dijimos, se dictaron 11, de los que se estudia su evolución y características a lo largo del periodo en el que se produjeron.

En el capítulo sexto se hace alusión a algunos aspectos concretos de los bandos, que resultan de un mayor interés, como era la cuestión de las armas, la vigilancia y 
los vagos junto a otros grupos humanos que supuestamente necesitaban de un mayor control, como los desertores, los trabajadores forzados o las gentes de color. Todo ello muy relacionado con los aspectos de seguridad, fundamentales para el buen gobierno de las ciudades, por lo que la nocturnidad también encuentra un apartado en este capítulo, ya que, como nos relata la autora, respecto de la noche existía "un temor subjetivo". Como consecuencia, no podía faltar un aspecto crucial, como lo era el referente a quienes debían encargarse del mantenimiento del orden y la justicia, siempre bajo la sospecha de abusos y corrupción. Quizá en este capítulo sexto echemos de menos un marco teórico mucho más amplio, habida cuenta del interés que en muchos aspectos hubo respecto a la seguridad tanto en el siglo XVIII como en el XIX y que fue tema tocado por muchos teóricos de la época.

Muy en relación con lo anterior, el capítulo 7 aborda los temas de moralidad y de religión en los bandos, pues es precisamente la actividad religiosa de los cabildos uno de los aspectos más regulada en los mismos. De hecho, como se nos refleja en este trabajo, los referentes al siglo XVIII, a pesar del racionalismo imperante en muchos teóricos de la época, comienzan con una declaración de fe. Pero también en su desarrollo se aprecia la secularización, pues, por ejemplo, en la percepción del delito hay un avance desde su identificación con el pecado a relacionarlo con el daño social que producía. También en los aspectos morales se tocan otros temas, como el del vestido o la cristianización de los esclavos; pero recordemos ahora el de la prostitución, que no se reguló hasta mediados del siglo XIX, y no con prohibiciones sino con aspectos que tenían que ver más con la higiene pública.

El capítulo 8 es que el la autora ha dedicado a los aspectos urbanísticos de los bandos, ya que los propios ilustrados tuvieron entre sus intereses el dar con la solución de lo que podría ser la ciudad ideal; en el caso de la isla que ocupa la obra, se llegaron a dar normas urbanísticas para recuperar el espacio público, como las de Ezpeleta o las de Santa Clara.

Se recuerda que la ciudad ilustrada, además debía tener muy en cuenta la salud pública y la higiene de ahí las intervenciones en el urbanismo del que es un buen ejemplo la propia ciudad de La Habana. En este sentido, los bandos no se olvidaban del espacio al que estaban orientados, que en el caso cubano tenían que ver con el clima tropical, por lo que los aspectos higiénicos eran imprescindibles y se tenían en cuenta aspectos como el control de los alimentos, los mataderos, las basuras, las canalizaciones de agua, etc. Hubiera sido de un gran interés en este sentido hacer referencia, aunque fuera de pasada, a algunos proyectos ideales que se trataron de 
llevar a cabo en algunas ciudades americanas de la época como los de Darquea, Navarro u otros proyectistas y autores, sin olvidar a un americano como Pablo de Olavide.

Se tratan igualmente los aspectos de de construcción y urbanismo, de los incendios y su control o del tránsito urbano. Precisamente en este último aspecto se nos pone de manifiesto la congestión a la que estaba sometida La Habana, con sus problemas de pavimentación por falta de piedra y la necesidad de las calles, todo ello coincidiendo con el aumento de calesas y volandas, que congestionaban un tráfico caracterizado por su velocidad, contra la que hubo que recurrir en la regulación. Pero no se olvidan otras cuestiones como el del abasto y comercio, con un interés relevante por el precio de los productos, especialmente de los alimenticios, así como otra serie de medidas en las que se trataba de defender a los consumidores.

El capítulo 9 está dedicado a las fiestas y juegos. Nada tiene esto de extrañar, pues La Habana disponía de tal cantidad de fiestas, algunas que se prolongaban hasta una semana, que hubo que reducirlas en 1789 a los domingos y días de precepto marcados por la Iglesia; incluso en 1790 se llegó a regular sobre las fiestas realizadas en las casas particulares. Pero los bandos se centraron sobre todo en las actividades lúdicas, en la medida en que afectaban a la buena marcha de la ciudad, puesto que el juego, llamado "cáncer devorador", formaba parte de lo que la autora denomina como la tríada del vicio, formada por este, por la prostitución y por el alcohol, tratando de ejercerse un gran control en las disposiciones sobre el mismo.

En el capítulo 10 se nos acerca a los aspectos punitivos, en un momento en que las penas trataron de racionalizarse con castigos más humanizados y con la búsqueda de la redención de los reos. De todos modos se tiene en cuenta que los bandos no tenían entre sus funciones ocuparse de los delitos criminales, además de que las penas se dejaban en manos de los jueces. Aun así, la autora establece tipos de penas que van de las corporales a las pecuniarias, pasando por las correctivas, que afectaban de manera muy especial a los menores.

Por último, el capítulo 11 se ha dedicado a los bandos de buen gobierno en otros lugares de la isla y en especial de la ciudad de Santiago, pero además los de Puerto Príncipe (1734, 1772 y 1811), Trinidad (1772 y 1775) y Matanzas 1784, 1787).

Al margen de la calidad de la obra, que es indudable, para los investigadores lo más interesante es la recopilación de un corpus de los bandos, hasta ahora dispersos en el Archivo Generalde Indias, en el Archivo Histórico Nacional y en otros archivos y 
biblioteca cubanos. Esto se hace por primera vez de una forma sistemática y se recoge entre las páginas 375 a la 696. Sin duda, se trata de un aporte documental de infinito valor para el estudio de la isla de Cuba en los años en que se desarrolla el trabajo, pues tales bandos afectaban al desarrollo de la vida en las ciudades y condicionaban para bien o para mal su desarrollo. Con esta investigación, otros estudiosos tienen a su disposición, de una manera ordenada y completa, lo que hasta ahora estaba disperso.

Podemos decir que la obra de Dorleta Apaolaza Llorente ha venido a completar un vacío en la historia cubana y deberá ser tenido en cuenta, a partir de ahora, en las investigaciones sobre la isla en los siglos XVIII y XIX. Por eso, el mayor defecto que encontramos en la obra, y que podrá subsanarse en ediciones posteriores, es la necesidad de un índice alfabético y temático, que facilite su consulta a los estudiosos.

Jesús Paniagua Pérez - IHTC - Universidad de León jesus.paniagua.perez@unileon.es 
Sección V: OTRAS INFORMACIONES 



\section{La fotografía en León (1839-1900).}

\section{Isabel BARRIONUEVO ALMUZARA \\ Director: Dr. Francisco Carantoña Álvarez \\ Tesis doctoral defendida el 5 de febrero de 2016}

La fotografía en León (1839-1900), de la que es autora Isabel Barrionuevo Almuzara, fue presentada como tesis, dirigida por D. Francisco Carantoña Álvarez, catedrático de la Universidad de León, y defendida en esa Universidad el 5 de mayo de 2016. El tribunal presidido por el catedrático de Historia Contemporánea de la Universidad Complutense de Madrid, D. Secundino José Gutiérrez Álvarez, y del que formaron parte D. Felipe Zapico Alonso, de la Universidad de Extremadura y D. Elena Aguado Cabezas, de la Universidad de León, la calificó con la nota de sobresaliente cum laude.

El mundo conoció el 'invento' de la fotografía en el año 1839, tras la presentación que el diputado francés François Arago realizó ante la Academia de las Ciencias y las Artes de París sobre los avances, químicos y físicos, realizados para fijar la imagen tomada de la realidad. Intentos que se materializaron en los daguerrotipos (placas de cobre pulido con imagen fotográfica) realizados por Daguerre.

La Fotografia en León (1839-1900) se sitúa en los orígenes de la fotografía en la provincia de León, sus primeras manifestaciones y el desarrollo de la profesión y los profesionales, así como de los aficionados, que ejercieron tanto de manera ambulante como con estudio fijo en el marco temporal señalado.

Se analiza la fotografía en León en el marco temporal establecido a lo largo de seis capítulos:

- Marco socio-económico de la investigación. Se contextualiza La fotografía en León. Cómo era, qué ocurría en la ciudad en el marco cronológico en el que el 'invento' fotográfico se da a conocer al mundo, en el año 1839, hasta 1900.

- La Meta: representar la realidad de manera fidedigna. Se describen los hechos conocidos sobre el descubrimiento de los primeros procesos fotográficos, efectuados por Niépce, Daguerre y Talbot, entre otros, así como las primeras realizaciones, en Barcelona y Madrid y las primeras manifestaciones en las ciudades de la actual Comunidad Autónoma de Castilla y León.

- La fotografía en León. Primeros contactos. Se inicia este apartado con la noticia de los 'dibujos al natural' ofrecidos en 1837 por un leonés y se centra 
en las décadas de 1850 y 1860 , etapa caracterizada por la presencia de los primeros fotógrafos en la provincia, viajeros y ambulantes, que realizaron retratos y fotografiaron por primera vez monumentos y paisajes. Se reseña brevemente la industria y el comercio fotográficos. El capítulo se cierra con un apartado dedicado al cine, la fotografía en movimiento.

- La fotografía en León. Los estudios fotográficos de los pioneros. El trabajo se detiene en el relato del paso de la fotografía de los ambulantes a las primeras galerías fotográficas establecidas en León en la década de 1860. Se incluyen, asimismo, referencias a las exposiciones regionales leonesas de 1876 y 1892 en las que tuvo presencia la fotografía provincial y nacional.

- La fotografía en León. Misiones fotográficas. Este capítulo se ha reservado para las misiones fotográficas: comerciales, científicas y documentales realizadas por fotógrafos profesionales foráneos y también por aficionados que se desplazaron a León durante el siglo XIX y primeros años del siglo XX para retratar la provincia.

- La fotografía en León. Las galerías estables. Este capítulo se dedica al relato de las galerías fotográficas que, tanto en León como en la provincia, perduraron en el tiempo, a los profesionales que las pusieron en marcha y a sus herederos, que las mantuvieron durante décadas.

En las conclusiones se da respuesta a las preguntas planteadas como objetivo de la tesis: quién y cuándo se fotografió, qué se fotografió, dónde se fotografió, y por qué se fotografió en la provincia de León entre 1839 y 1900.

- Quién y cuándo se fotografió en la provincia de León entre 1839 y 1900. La primera noticia registrada sobre la fotografía en León, la daguerrotipia, es del 9 de noviembre de 1844. Un anuncio en el Boletín Oficial de la Provincia informa a los leoneses sobre la posibilidad de adquirir en el establecimiento comercial de la Imprenta de Miñónla máquina y accesorios llegados de París para hacer retratos.

Por otro lado, el primer daguerrotipista que intentó ganarse la vida haciendo retratos en Castilla y León, Bernardo Fernández Neira, había nacido en León y en la ciudad mantuvo su actividad como pintor y profesor de dibujo hasta la década de 1830, pero no fue en la capital de la provincia son en Valladoliddonde decidió aventurarse con la técnica fotográfica.

Aunque no se descarta que la primera técnica fotográfica, el daguerrotipo, fuera ejercida por algún profesional en la provincia de León, alguien que adquiriera el equipo 
que comercializaba Miñón en 1844 o por alguno de los fotógrafos ambulantes, no disponemos en la actualidad de ningún artefacto que lo atestigüe.

Sí que podemos asegurar la existencia de positivos obtenidos de papeles a la sal, el procedimiento de negativo-positivo que siguió a los daguerrotipos (imágenes directas sobre metal). Se trata de la fotografía de la Catedral realizada por Edward Tenison en 1851 y las de Charles Clifford en 1854 de la Catedral, San Isidoro y el convento de San Marcos.

A los fotógrafos viajeros señalados, le siguieron los ambulantes: Galtier, Juan José García Peribáñez, Rafael Almazán Idelmón, Madame Ludovisi, Juan Pérez Galiano, Juan Peinado, Juan M. Ocaña, Gerier y Antonio de Inés, que acudían en las fechas señaladas de las ferias de León y Astorga a realizar retratos.

Casimiro Alonso Ibáñez y José María Cordeiro en León y Matías Rodríguez Díez en Astorga fueron los pioneros que fotografiaron León y a los leoneses en la década de 1860 añadiendo a la profesionalidad de los ambulantes, galerías estables, decorados y la ambientación y ornamento propios de las galerías del siglo XIX.

Las empresas editoriales de postales más reconocidas de España: Hauser y Menet, J. Laurent y Thomas enviaron a sus profesionales la provincia desde mediados de la década de 1880 para fotografiar calles, plazas y monumentos y a los 'tipos populares', para editar postales fotográficas.

Obras públicas de envergadura, como la construcción del ferrocarril a Asturias desplazaron a Paul Sauvanaud a León en 1883 y trabajos sobre el patrimonio históricoartístico, como el emprendido por Casiano Alguacil (un catálogo monumental de España) o misiones científicas y técnicas como la del Conde de Saint-Saud y su interés en 1892 por los Picos de Europa o la del zoólogo Hans Friedrich Gadow en 1895 o la del ingeniero Manuel Diz y sus colonias escolares también en 1895, atrajeron. a la provincia a estos profesionales y aficionados con sus equipos de fotografía.A finales de 1887 se instala en León Germán Gracia, el fotógrafo que retrató durante casi cuatro décadas la ciudad de León y sus habitantes y con él se cierra el siglo XIX.

- Qué se fotografió en la provincia de León entre 1839 y 1900 . Además de retratos individuales y en grupo, hasta avanzada la década de 1890, las fotografías de León son principalmente de monumentos, plazas y calles, así como 'tipos del país', como las realizadas por J. Laurent a habitantes de diferentes comarcas leonesas (montañeses, ribereños y maragatos) que, con motivo de la boda del rey Alfonso XIII con María de las Mercedes, viajaron a 
Madrid y fueron retratados el 23 de enero de 1878. Germán Gracia realizó series de postales con la imagen de aldeanos que en los días de feria acudían a León y se retrataban en su galería. Son imágenes de la década de 1890.

- Dónde se fotografió. En cuanto a monumentos, el mayor interés estuvo en la ciudad de León: la Catedral, San Isidoro, el convento de San Marcos y sus museos, la iglesia del Mercado, la Casa Consistorial, la estación de ferrocarril, la Torre de los Ponce, la iglesia de San Pedro de los Huertos, el Palacio de los Guzmanes, las murallas y la Plaza Mayor y en la provincia: el puente sobre el río Sil, en Ponferrada; San Miguel de Escalada, Grajal de Campos, Sahagún, y Astorga.

De nuevo será Germán Gracia quien realice, ya a finales del siglo XIX, fotografías de la calle Ordoño II, de la plaza de San Marcelo, de la plaza del Espolón o de la Plaza del Grano, así como del puente de la Estación.

- Por qué se fotografió en la provincia de León. Máquina o pincel es un debate que se suscitó incluso antes de la presentación oficial del daguerrotipo en 1839 en París y que permanece vivo en la actualidad.

El interés científico, a la par que lúdico, por documentar la realidad, lo vivido, lo conocido, es lo que movió a los viajeros románticos que a mediados del siglo XIX recorrieron España en busca de lo exótico, de lo diferente, siguiendo la estela de quienes en los primeras décadas del siglo XIX habían viajado por España provistos de papel y lápiz tomando apuntes y dibujando lo que más les atraía: la belleza pintoresca, el paisaje, la antigüedad y las ruinas, algo que merced al desarrollo industrial asentado en otros países europeos como Inglaterra, Francia o Alemania, comenzaba a ser un bien escaso; España, un país anclado en otro siglo, era para ellos el mayor atractivo.

La generalización de las técnicas fotográficas de mediados del siglo XIX provocó, de alguna manera, el declive del universo romántico, del orientalismo pictórico, que poco a poco irá sucumbiendo al pragmatismo y la objetividad de la instantánea fotográfica.De los seis viajeros-fotógrafos más conocidos que recorrieron España entre 1839 y 1860 sólo dos, el matrimonio Tenison y Charles Clifford, recalaron en León. Además de que la meta era Andalucía, pesaba en la elección del destino su precario nivel de comunicación con el resto del país.

A los viajeros que fotografiaron la provincia hay que sumar los fotógrafos ambulantes, sin galería o estudio fijo, los que viajaban por España y se establecían por temporadas en una ciudad para hacer retratos. Las ferias y mercados eran su espacio natural y en ese sentido sí que León contó una presencia similar a la del resto de 
capitales de provincias del entorno.

Lo mismo ocurrió con las manifestaciones precinematográficas. Las primeras se producen en la década de 1860 y son permanentes hasta finales de siglo. Las feria sí que tenían público y las linternas mágicas y cosmoramas, así como el resto de espectáculos, el éxito asegurado.

Lo que profesionales como J. Laurent, Josep Thomas y Casiano Alguacil pretendían hay que buscarlo en un fin comercial (vender vistas postales o disponer de un archivo monumental para editoriales); y los fotógrafos que establecieron sus galerías en León y Astorga, en el caso de Casimiro Alonso Ibáñez y Matías Rodríguez, en un interés científico (su afición a la arqueología y a la historia motivó el uso de la fotografía como herramienta para documentar sus hallazgos).

Para José María Cordeiro y Germán Gracia sí que se trataba de un medio de vida. Pero tan sólo estos dos fotógrafos se dedicaron exclusivamente a la fotografía profesionalmente. El éxito de su negocio dependía de la demanda que generase su oficio, algo directamente relacionado con el tamaño (población de la ciudad) y el desarrollo económico y comercial de la misma.

El nivel de desarrollo económico y cultural de León no propició que la sociedad del siglo XIX generara una demanda suficiente como para que se desarrollasen más estudios fotográficos estables. Hasta avanzada la década de 1860, los fotógrafos transeúntes que se desplazaban desde otros puntos de la geografía más próxima satisfacían el interés de los leoneses por la fotografía en las ferias y mercados, la máxima expresión durante décadas del intercambio comercial de la provincia.

\section{La decisiva participación de los $6^{\circ}$ y $7^{\circ}$ ejércitos españoles en el triunfo aliado en las campañas de 1811 y 1812 durante la Guerra de la Independencia.}

\section{Arsenio García FUerTeS \\ Director: Dr. Francisco Carantoña Álvarez \\ Tesis doctoral defendida el 15 de enero de 2016}

El noroeste peninsular fue uno de los campos de operaciones principales del primer año de la guerra de la Independencia $(1808$ - 1814). A partir de 1809 , los poderosos 
aliados británicos harán de Portugal y su capital Lisboa, la base logística de sus operaciones peninsulares, centrando su eje de avance en España, a partir de 1811, sobre Extremadura y Salamanca.

En el noroeste de España (Galicia, Asturias, León, y Zamora) las tropas españolas allí destacadas (sucesivamente renombradas como "Ejército de Galicia", de la "Izquierda" y, finalmente, "6 $6^{\circ}$ Ejército") se convertirían, a partir de 1810 , en el imprescindible flanco norte del ejército aliado anglo lusitano de Arthur Wellesley hasta 1813.

El eje estratégico principal de este decisivo conflicto peninsular (en la historia de las guerras napoleónicas) se libró entre los valles del Tajo y del Duero y la frontera portuguesa. Esta zona era la puerta de entrada a Portugal desde España para el ejército imperial (y viceversa para el ejército aliado de Wellesley; el único capaz de lograr victorias decisivas de carácter estratégico que pudieran desequilibrar el dominio bonapartista sobre la Península). En el resto de frentes de guerra, a lo largo y ancho de España, el ejército español, (obligado a combatir, dividido y aislado, por líneas exteriores en siete pequeños cuerpos de ejército) realizó, a partir de 1810, una tenaz guerra de movimientos y desgaste con pequeñas operaciones (la única posible con los medios disponibles), que, sin embargo, lograría fijar a la mayor parte de l'Armée de Espagne (con efectivos, a lo largo del conflicto, entre los 250.000 y 300.000 hombres), en operaciones secundarias de control del territorio y comunicaciones, impidiendo la concentración de su vasta fuerza, la cual hubiera, sin duda, logrado batir a Wellesley, expulsando a los británicos de la Península y decidiendo, así, la guerra en ella a favor de la causa napoleónica.

Derrotado estratégicamente, entre 1808 y 1809, el ejército regular español (muy inferior al francés), junto con los nuevos contingentes armados de "guerrillas", tuvieron que renunciar a una guerra clásica de movimientos ofensivos de la escuela prusiana (en la que habían sido educados los generales y mandos españoles). La alternativa fue la mencionada guerra defensiva, de erosión y desgaste constante contra las fuerzas imperiales, sobre todo en la periferia peninsular, pues los franceses dominaron enseguida, a partir de 1809, su centro geográfico (Madrid y las dos Castillas). Con ello los imperiales lograron, a partir de 1810, la gran ventaja estratégica de poder operar y combatir por líneas interiores, es decir, tener en rápida comunicación a todos sus cuerpos de ejército que podían ser apoyados y reforzados, ventajosamente, ante los intentos de ofensiva españoles y anglo lusitanos sobre cualquiera de los frentes de batalla periféricos. Algo que no podían hacer los españoles. 
El esfuerzo militar español durante el conflicto se vio también condicionado por la conflictiva dialéctica entre el poder militar y el poder civil, supeditado el primero al segundo (representado por las Juntas, las Cortes y el Consejo de Regencia), que asumiría la dirección de la guerra (en sus inicios caótica y descentralizada) y el precario sostenimiento económico del gran esfuerzo militar desarrollado entre 1808 y 1814.

Dichos frentes de batalla de los siete ejércitos españoles se convertirían en "frentes secundarios" a nivel estratégico, pero imprescindibles a nivel operacional y táctico, pues de ellos dependía la inmovilización de la mayor parte de los contingentes imperiales, su desgaste, y con todo ello, la única posibilidad estratégica de que, a partir de 1811, y, sobre todo, de 1812 (en el contexto de la invasión napoleónica de Rusia, y el debilitamiento, que ello supuso, para la continuación del esfuerzo militar imperial en España), el ejército anglo lusitano de Wellesley, el único que a nivel operacional y táctico podía batir en una campaña de batallas clásicas decisivas estratégicas, a las fuerzas imperiales, pudiera pasar a la ofensiva.

Ofensiva aliada de Arthur Wellesley contra uno de los dos ejércitos imperiales que operaban en el occidente peninsular, l'Armée Sud del mariscal Soult que ocupaba la Andalucía occidental, o l'Armée de Portugal, al mando del mariscal Marmont, que se desplegaba entre la frontera portuguesa y el valle del Duero.

Para lograr este éxito estratégico, evitando que los otros cuatro ejércitos imperiales (Norte, Cataluña, Aragón y Centro) pudieran concentrarse en su socorro, era imprescindible el papel activo de los siete ejércitos y guerrillas españoles.

Este trabajo aborda y demuestra cómo entre 1811 y 1812 (este último, el año en que cambió el curso del conflicto), la aportación militar española fue imprescindible para que Arthur Wellesley desarrollara, con libertad y éxito, sus planes ofensivos estratégicos sobre el valle del Duero; planes y operaciones que llevarían a la gran victoria de los Arapiles (22 de julio de 1812), a la liberación de Madrid (el 12 de agosto) y a la ofensiva final, fallida, hasta Burgos (septiembre - octubre).

En esta decisiva aportación militar española, este trabajo de investigación se centra en el papel desempeñados por el $6^{\circ}$ y $7^{\circ}$ ejércitos al mando de los generales José María de Santocildes y Gabriel de Mendizábal. El primero amenazará, en el verano de 1812, la retaguardia de l'Armée de Portugal del mariscal Marmont (precipitando una ofensiva prematura sobre Wellesley, el cual pudo combatir, gracias a ello, en igualdad de condiciones en los Arapiles), mientras que el segundo (formado a partir de la amalgama de las fuerzas guerrilleras del norte de España situadas entre los vértices 
que van de Irún a Santander, y de estos puntos a Burgos y Pamplona), amenazaría y disputaría, de manera constante y efectiva, el principal eje de comunicaciones imperiales entre Francia y Madrid, obligando a Napoleón a tener que destinar a su defensa a todo un ejército francés al completo, l'Armée du Nord.

El $7^{\circ}$ ejército guerrillero español, además de atraer sobre sí, durante más de tres años, al doble de fuerzas francesas de sus propios efectivos, ayudaría también al éxito de los Arapiles imposibilitando el auxilio de l'Armée du Nord a l'Armée de Portugal. El $7^{\circ}$ ejército, salvaría, además, de un desastre al ejército aliado de Wellesley cuando éste, tras su fracaso ante el castillo de Burgos, hubo de emprender una precipitada retirada invernal hacia Portugal en octubre de 1812.

Los imperiales perderían la guerra en la Península Ibérica (amén del contexto estratégico europeo que se vuelve contra Bonaparte a finales de 1812), porque fueron incapaces de concentrar su esfuerzo militar sobre el eje estratégico principal que eran los valles del Duero y del Tajo sobre la frontera portuguesa. Allí era donde, en verdad, se jugaba la victoria y la derrota en la guerra.

Esa imposibilidad imperial de concentración de fuerzas, favorable a los aliados, fue posible, sólo y gracias, al ejército regular y a las guerrillas españolas (por este orden), y en especial, merced a los $6^{\circ}$ y $7^{\circ}$ ejércitos españoles.

Por otra parte, contrariamente a la tesis historiográfica predominante que sostiene que España fue ninguneada en los sucesivos congresos aliados que llevarían a la reunión en Viena en 1815, y que afirma que se llegó a ellos como potencia vencedora y salió de ellas como potencia secundaria y vencida, hay que apuntar que España, o no estuvo presente, o llegó tarde a las conversaciones, y si lo hizo se presentaría en las sucesivas conferencias de paz sin posibilidad política, ni material, de hacer valer sus reivindicaciones.

En realidad España carecía ya de peso internacional como potencia en 1808 (en esa época se había convertido en un satélite aliado de Francia); las renuncias de Bayona y la entronización de José Bonaparte como rey de España se vieron en las cortes europeas con una mezcla de sorpresa, indiferencia y desprecio por la casa reinante Borbón sometida a semejante humillación. España ya no contaba entre las grandes potencias europeas en 1808, y el final de las guerras napoleónicas no supuso un cambio sustancial en dicha apreciación. España no salió derrotada en el Congreso de Viena, por la simple razón de que llegó a dicho encuentro sin aliados, y sin ninguna posibilidad real de hacer valer sus méritos contraídos entre 1808 y 1814. 
El gobierno español (Consejo de Regencia y Cortes - ya reunidas en Madrid - y luego el propio Fernando VII y sus colaboradores) mostraron además una falta total de una línea diplomática clara. Las disensiones políticas internas españolas entre liberales y absolutistas (que desembocarían en el golpe de estado de Fernando VII del 4 de mayo de 1814), agravaron esa falta de consistencia y claridad en los objetivos de la política exterior hispana durante los cruciales meses de 1814 y 1815 que tantos cambios presenciaron en Europa durante los últimos estertores del imperio napoleónico.

Entre las causas reales podemos apuntar, por ejemplo, que en pocos meses, y debido a las tensiones políticas internas en España, la representación plenipotenciaria española ante los aliados cambió en tres ocasiones de mano con las consiguientes ausencias de un interlocutor válido y autorizado ante las cuatro grandes potencias, amén de una total improvisación: José García de León y Pizarro, Fernán Núñez y Pedro Gómez Labrador.

Por ello, la diplomacia española no estuvo presente en la reunión y firma del Protocolo de Langres del 29 de enero de 1814 en el que las cuatro grandes potencias aliadas formularon sus propuestas de paz a Bonaparte. Tampoco se tuvo en cuenta las reivindicaciones españolas en el Congreso de Châtillon abierto el 5 de febrero y al que España, ya hemos apuntado, no fue invitada formalmente por los cuatro grandes.

La ya conocida supeditación militar y exterior española respecto a Gran Bretaña y los intentos diplomáticos españoles de acercamiento, en la segunda mitad de 1814, a una Francia que volvía a estar en manos de los borbones, no ayudaron tampoco a mejorar la imagen y la influencia de España en las cortes de Europa.

El militar e historiador alemán, Bertold Schepeler, presente en la Península durante el conflicto, así lo manifestó en 1831 a la conclusión a su obra sobre la Guerra de la Independencia española cuando mencionó que:

"España se había desangrado en aquella empresa y Europa no le agradeció este sacrificio". ${ }^{608}$

Por todo lo anteriormente expuesto, recalcamos que la minusvaloración del peso militar de España en la victoria final aliada contra el imperialismo napoleónico, contribuyó decisivamente a su debilidad política en el contexto de la victoria aliada en

${ }^{608}$ H. Juretscheke (1962). "El coronel von Schepeler. Carácter y valor informativo de su obra historiográfica sobre el reinado de Fernando VII". Revista de Estudios Políticos, 126: pp. 229249, p. 248. 
1814 y 1815 , a su postergación en los acuerdos de paz (culminados en el Congreso de Viena) y, en parte, e indirectamente, al inicio de su aislamiento de Europa durante el siglo XIX.

Por ello, esta obra ha pretendido recuperar para la historia, el esfuerzo decisivo militar español en el inicio de la derrota de la aventura napoleónica en Europa en 1812. $\mathrm{Y}$ en estos hechos, hay que dar a conocer y reseñar la actuación abnegada, constante y victoriosa de $\operatorname{los} 6^{\circ}$ y $7^{\circ}$ ejércitos españoles en el noroeste de la Península Ibérica entre 1810 y 1813.

\section{Población, sociedad y familia en Tierra de Campos leonesa. La comarca de Sahagún en el s. XVIII.}

\section{Francisco Javier LAGARTOS PACHO}

Director: Dr. Juan Manuel Bartolomé Bartolomé

Tesis Doctoral defendida el 21 de enero de 2016

Para el conocimiento de cualquier ámbito cultural humano del pasado es necesario analizar las estructuras de una sociedad, especialmente los parámetros demográficos y sociales, en nuestro caso, aquellos que tiene relación con la familia y su perpetuación en el tiempo. La familia, como la célula básica de una sociedad, comprende infinidad de ámbitos de estudio: herencia, relaciones de parentesco, consanguinidad, estrategias y alianzas matrimoniales, etc., que son necesarios entender para un buen conocimiento de la misma y de la sociedad en la que está inserta. El objetivo de esta investigación ha sido el de conocer, desde la perspectiva de la historia de la familia, cuales son las pautas demográficas y cómo se llevaba a cabo el entramado familiar para conseguir el objetivo final de toda sociedad que es la perpetuación del sistema.

La consecución de este objetivo se ha plasmado geográficamente en el sureste de la actual provincia de León, en concreto en la comarca de Sahagún, y en un espacio temporal que abarca, principalmente, el siglo XVIII. Es un territorio con características propias de las zonas geográficas de transición, es decir, presenta unas particularidades que le vienen dadas de la mezcla de los modelos limítrofes perfectamente definidos, en este caso, entre los territorios de las estribaciones de la montaña leonesa y la ribera del río Esla y las zonas llanas castellanas de lo que se conoce como Tierra de Campos vallisoletana y palentina. Con este estudio hemos desmontado una serie de estereotipos 
que se han ido asentando y que giran en torno, por ejemplo, a la localización geográfica o a la homogeneidad de los parámetros socio-demográfico y que se han demostrado falsos. Ha contribuido a extender esta imagen de indefinición geográfica, simplicidad y homogeneidad la escasez de estudios relacionados con los ámbitos sociales (familia, herencia) y económicos (subsistencia) cuyo eje vertebrador sean zonas de transición, más acentuada esta carencia en el sureste leonés. Con este estudio hemos superado el aspecto geográfico, territorial y nominativo a la vez que hemos introducido planteamientos historiográficos basados en el análisis del ámbito familiar y social de forma diferenciada sin que uno condicione la forma del otro.

Nuestra investigación se ha basado en tres grandes pilares fundamentales. Hemos analizado todo lo referente al conocimiento de la población y las características de los agregados domésticos para acercarnos al potencial demográfico de la zona. Estudiando la natalidad, mortalidad y nupcialidad, la cual, nos ha abierto el camino para comprender la formación, constitución y consolidación del matrimonio como uno de los conceptos claves de nuestro estudio.

Después hemos estudiado la estructura económica de las explotaciones agrarias, la propiedad agraria y su distribución, el aprovechamiento del terreno, etc. relacionándolo con la familia y el hogar. Esta sociedad desigual ante la que nos encontramos, nos aleja de esas idílicas comunidades de carácter igualitario, aunque bien es cierto que las diferencias entre los distintos grupos están menos marcadas en la comarca de Sahagún que otras regiones de la península. Estamos hablando de una sociedad compuesta por pequeños y medianos propietarios caracterizados por desarrollar estrategias laborales muy variadas, no dudando en utilizar los recursos disponibles, tanto materiales, humanos, como laborales, para conseguir la reproducción del sistema. Aunque la mayor parte de los individuos aparecen con ocupaciones muy definidas y determinadas, lo cierto es que es muy frecuente la combinación del trabajo en su reducida explotación agraria con el trabajo asalariado, principalmente en el campo, aunque también en algunos pequeños talleres, como pastores de los grandes rebaños o como sirvientes domésticos en las casas de los terratenientes, con el objetivo de conseguir un mayor bienestar familiar y una perpetuación en el tiempo y en el espacio de la unidad familiar. En todo este desarrollo jugará un papel importante la mujer, colaborando en muchos de los procesos económicos, y los hijos, ayudando en las tareas agrícolas o con un aporte económico exterior, es decir, podemos ver como la importancia de la familia es vital en todo este proceso. 
Y, por último, analizamos los mecanismos utilizados por los individuos de la zona para la reproducción social, deteniéndonos en la transmisión de las herencias (propiedad, oficios, bienes muebles e inmuebles, etc.), la organización de las alianzas familiares, las redes de relación, etc. en definitiva todos aquellos aspectos que nos pongan sobre las pista de la forma en la que se perpetúa el sistema de generación en generación. En la práctica hereditaria se impone el igualitarismo frente a otros mecanismo que intentan suavizarlo, como es el caso la mejora post mortem y las mandas testamentarias y legados, aunque su utilización es algo menor que en otras zonas. La importancia del control que supone su utilización se une la voluntad intencionada de dirigir la familia en un determinado sentido, aquel que el testador considere el más idóneo para conseguir el fin último: mantener o mejorar la posición social. Así, este tipo de recursos se convierten en algo muy utilizado cuando desean burlar el sistema igualitario castellano, posibilitando el aumento patrimonial de sus beneficiarios y provocando con ello el distanciamiento económico entre los diferentes miembros de una familia, según las diferentes estrategias seguidas por las jefaturas familiares.

Nuestro interés siempre fue el de llegar a un análisis más dinámico que nos ha llevado a comprender la desigualdad que se produce entre los diferentes hogares y la permanencia de la misma en el tiempo y en el espacio, centrándonos en los miembros de las ocupaciones agrarias (labradores, jornaleros y pastores), que representan dos tercios del total de efectivos de la zona. Entre jornaleros y pastores la tendencia es la juventud, viendo en esta salida profesional la incorporación al mercado laboral, ya que, apenas poseían una explotación agraria propia. Toda esta situación se invierte a partir de los 35-40 años y se acelera a partir de los 50-55 años a favor de los labradores, llegando a representar un número importante los labradores mayores de 70 años. Así, los asalariados se caracterizan por la transitoriedad en edades tempranas frente a la permanencia de su trabajo asalariado más allá de los 55-60 años, mientras que la disminución del número de jornaleros y la superioridad de los labradores a partir de los 40 y 55 años, respectivamente, es fruto de una movilidad socio-profesional entre ambos grupos. La situación social viene a ser otro elemento de cambio y está determinada, en gran parte, por la propiedad. La posición social en base a este parámetro puede variar en el tiempo, no permaneciendo inmutable a lo largo de la vida de un individuo, ya que existen múltiples mecanismos que modifican los niveles de propiedad y, en consecuencia, la pertenencia o no a un estrato social determinado, constatando en nuestra zona de estudio como el tipo de actividad desempeñada a lo largo de la vida y la edad del individuo están relacionadas con el número de 
propiedades agrarias que posee. De este modo, la ocupación agraria lleva consigo que los cabezas de familia vayan ascendiendo desde el punto vista económico, pero no ocurre así con otras profesiones como los jornaleros, que con mucho esfuerzo y con el paso del tiempo, llegarán a conformar pequeñas haciendas en base, principalmente, a dos actuaciones: por los aciertos económicos que se producen en el seno del propio hogar y por las prácticas hereditarias y el dirigismo familiar por medio del recibo de donaciones, de otras herencias de familiares cercanos como tíos/as solteros/as, curas, etc.

En definitiva, nuestro trabajo ha partido de los nuevos postulados teóricos acerca del estudio de la familia en el que, sin abandonar el análisis general tradicional, hemos intentado prestar mayor atención a los comportamientos diferenciales y a las prácticas sociales, donde el individuo no es contemplado como algo rígido sino como un actor pensante y director de sus destinos.

Con estas premisas metodológicas hemos conseguido aumentar nuestro conocimiento acerca de los aspectos familiares y su relación con el medio y la sociedad propia del siglo XVIII en la comarca de Sahagún, desentrañando los entresijos que determinan la formación, consolidación y el establecimiento de una nueva unidad familiar. Además, hemos puesto de manifiesto cómo se perpetuaban y reproducían las acusadas diferencias que encontramos en el mundo rural, poniendo en relación la familia y los recursos, a la vez que hemos dejado el tema abierto para futuras explicaciones de acontecimientos o para posteriores ampliaciones de los aspectos familiares cotidianos y su relación con el medio y la sociedad propia del siglo XVIII en Tierra de Campos leonesa.

Con todo ello, en nuestro estudio hemos intentado aproximarnos a la familia terracampina partiendo de su análisis bajo tres parámetros fundamentales: hogar, trabajo y explotación agraria y su transmisión, como metodología para explicar los cimientos y componentes del funcionamiento del sistema social. De este modo, hemos interrelacionado el agregado doméstico con la explotación agraria, sobre la cual hemos situado los diferentes grupos sociales en base a unos parámetros prefijados con anterioridad. 


\section{Construyendo la democracia. Tardofranquismo, transición política y la cuestión autonómica en la provincia de León (1962- 1984).}

\section{David MARTínEZ PÉREZ \\ Director: Dr. Francisco Carantoña Álvarez \\ Tesis doctoral defendida el 28 de enero de 2016}

Esta investigación comienza con un análisis demográfico y económico de la provincia durante la dictadura franquista. Para posteriormente explicar las características de la oposición antifranquista en el ámbito leonés, en donde destacó el PCE y la acción católica obrera. En la etapa final del franquismo comenzaron a abrirse lentamente espacios democráticos, entre los que cabe destacar el IV congreso nacional de la abogacía española (1970) y la oposición a la instalación de la central nuclear de Valencia de don Juan (1975). La conflictividad laboral resultó fundamental durante el tardofranquismo. Para poder conocerla se organizó en diversos períodos, que comenzaban con la oleada huelguística minera de 1962. Después de una etapa de calma, la crisis de la minería y la elaboración de los convenios colectivos contribuyeron al incremento de la disrupción laboral entre 1968 y 1971. Posteriormente disminuyó el número de conflictos en la provincia, pese a que se incrementó en el ámbito estatal.

El siguiente apartado explica la evolución de la Transición democrática en León. Resultaron fundamentales en este aspecto la configuración de las asociaciones políticas (todavía franquistas), la organización de los grupos de la oposición y el surgimiento de los nuevos movimientos sociales (feminismo o asociaciones vecinales). Asimismo se investigaron los resultados del referéndum de la ley para la reforma política. Que evidenciaron la diferenciación entre zonas abstencionistas, tal vez cercanas a la oposición y favorables al voto afirmativo. En esta etapa la conflictividad sociolaboral se incrementó y extendió a sectores antes tranquilos como la agricultura o la construcción. Resultaron esenciales las primeras elecciones democráticas, que tuvieron lugar en junio de 1977, y que mostraron la importante victoria de la UCD, que se repitió en los comicios de 1979, tanto legislativos como municipales. El apoyo de la mayoría de los partidos políticos a la constitución de 1978 explica el éxito de los sufragios afirmativos en ese referéndum, pero en pequeñas poblaciones del sur y este provincial la abstención y los votos en contra fueron destacados.

Finalmente se indagó sobre la cuestión autonómica en León. Se partió para ello de 
la evolución de los regionalismos en la provincia desde el siglo XIX hasta la dictadura franquista. La evolución de la organización territorial de España durante la Transición propició la aparición de organizaciones e instituciones regionales. Cabe señalar a la alianza regional de Castilla y León, el instituto regional de estudios castellano-leoneses y el grupo autonómico leonés. Como hechos reseñables se encontraron las manifestaciones a favor de la autonomía leonesa, y el cambio de posición de la UCD y el PSOE en 1980 a favor de la entrada en Castilla y León. Mientras la autonomía se consolidaba en La Rioja y Cantabria, en León no se realizó ningún trabajo legislativo, la responsabilidad, por tanto, fue de buena parte de la ciudadanía y de algunos políticos. Sin embargo, cuando el mapa autonómico estaba cerrado, se produjo una fuerte reacción de los grupos conservadores a favor de la autonomía leonesa, lo que contribuyó a que aumentara el volumen de las movilizaciones. Pero la sentencia del Tribunal Constitucional en 1984 que incluía a León dentro de la autonomía de Castilla y León generó una enorme frustración en el movimiento leonesista.

La economía de posguerra en la provincia de León (1937-1953): El Servicio Nacional del Trigo, los molinos y las fábricas de harinas. Los años del hambre y del estraperlo.

Javier ReVIlla CASAdo

Director: Dr. D. José Javier Rodríguez González

Tesis doctoral defendida el 19 de enero de 2016

El objetivo principal de esta Tesis Doctoral ha sido investigar la economía agrícola y sus industrias transformadoras -especialmente los aspectos vinculados al trigo, la harina y el pan-, en la provincia de León y para el período de la posguerra franquista. Así, documenta a través de fuentes archivísticas la dura realidad social de aquellos años y la respuesta al intervencionismo estatal de la producción triguera, hecho que supuso también un absoluto control sobre la harina y el pan (racionado hasta 1952).

Una de las principales conclusiones obtenidas ha sido la comprobación de que, pese al imperioso intento de control estatal -tanto de las producciones agrícolas, como de su transporte y depósito, así como de su transformación para el consumo-, las instituciones creadas por el franquismo fueron incapaces de conseguirlo en los años estudiados. No lo lograron eficientemente ni el Servicio Nacional del Trigo, ni la 
Comisaría General de Abastecimientos y Transportes, ni las Fiscalías de Tasas, entre otros organismos.

La investigación se centra en la documentación existente sobre el Servicio Nacional del Trigo (SNT) relacionada con la provincia de León. El SNT fue creado el 23 de agosto de 1937 con objeto de llevar a cabo una "intervención totalitaria" de la producción triguera, de tal modo que los agricultores quedaron obligados a declarar sus cosechas y a venderlas al Estado a cambio de su precio oficial de tasa. El SNT a su vez distribuía el trigo entre los transformadores -molinos y fábricas de harinas-, a unos determinados valores y según unos cupos; también la harina resultante y el pan cocido tenían marcados sus precios, completándose así un proceso completamente encorsetado. A ello hay que añadir que el SNT controlaría puntualmente otros cereales y leguminosas.

Para almacenar las producciones intervenidas, el SNT estableció una red de graneros o paneras a lo largo de la provincia de León, partiendo de 8 almacenes arrendados ya en 1937 y llegando a tener más de 30 en la década de 1950. La promesa de construir una red de silos propia se estancaría durante años, siendo el primer silo del SNT el inaugurado en Córdoba en 1951, mientras que la provincia leonesa no contó con este tipo de edificios hasta 1954 (silo de Valderas) y el resto -hasta totalizar 11- se construyeron más tardíamente.

Las consecuencias de la autarquía triguera fueron muy negativas. La caída de la producción fue tal que, en el año 1945, en el conjunto de España se produjo un 60\% menos de trigo que en la media del quinquenio 1931/35 (en León la cifra es algo mejor, $-50 \%$, pero de igual modo desastrosa). Ello obligó, por ejemplo, a realizar grandes importaciones de grano desde Argentina y otros países, pese a que el SNT nació como oposición a ello. Con todo, la consecuencia más trágica fue la generalización del hambre.

Otra secuela muy negativa fue el anquilosamiento de la agricultura leonesa. Queda constatado un gran atraso tecnológico, pues en 1956 apenas había en toda la provincia 96 tractores, 25 trilladoras o 40 segadoras. Las faenas, por tanto, eran realizados masivamente de modo manual o con ayuda de yuntas de labor (unas 60.000 cabezas en 1948 , casi el $80 \%$ vacunas). Tampoco se puede hablar prácticamente de fertilizantes -salvo los abonos naturales- ni de mejora/selección de semillas.

Como resultado, se producía poco y se trataba de ocultar porque los precios de tasa oficiales eran inicialmente muy bajos -incluso inferiores a los costes de producción-, 
mientras que en el estraperlo se disparaban. Así, el recurso al mercado negro fue en unos casos por obligación (como mecanismo de supervivencia), mientras que otros lo hicieron para enriquecerse.

En la campaña 1940/41 los propios Servicios Agronómicos reconocieron públicamente que casi la mitad de las producciones agrícolas de la provincia de León circulaban por lo que las autoridades denominaban "mercado invisible". Cifraron en un $38 \%$ el trigo que se vendía ilegalmente; y el 37\% de las alubias, el $51 \%$ de la cebada o el $52 \%$ de los garbanzos. Debemos entender que en años precedentes las cifras habían sido aún más escandalosas, puesto que estos datos se difundieron como supuesta demostración de la mejora en los controles.

Esta tesis estudia las 27 fábricas de harinas que tuvieron actividad durante la posguerra en la provincia de León y documenta una significativa parte de los molinos maquileros que existían en aquel momento -al menos 602-. Establece los beneficios obtenidos por unos y otros: los fabricantes leoneses llegaron a ganar más de 1 peseta por cada kilo de harina a mediados de la década de 1940 (ganancia bruta: sin restar gastos de producción), mientras que los molineros percibían la maquila, un cobro en especie que solía rondar el $4 \%$ del trigo que se les llevaba a moler. Ambos valores se dispararían en el estraperlo.

Por tanto, los fabricantes harineros -los industriales capitalistas- fueron los grandes beneficiados del período. En el lado opuesto, los molineros sufrieron duramente la legislación y la represión franquista, hasta el punto de que se les llegó a prohibir totalmente su actividad entre 1940 y 1949 ante la imposibilidad gubernamental de controlarlos; especialmente dura fue la etapa en que Arias Navarro fue Gobernador Civil de León, constatándose entonces numerosos cierres, sanciones y detenciones.

Se evidencia que, además del generalizado mercado negro -el cotidiano, a pequeña escala y/o de supervivencia- existió lo que esta investigación denomina "gran estraperlo", considerándose como tal el desarrollado para amasar grandes fortunas. Así, esta Tesis Doctoral estudia por primera vez varias redes de contrabando de trigo en la provincia de León, con casos sorprendentes en los que, por ejemplo, aparecen implicados funcionarios de hasta 6 ayuntamientos leoneses; destaca la detención nocturna, en Valencia de Don Juan -agosto de 1950-, de un camión cargado con trigo ilegal cuyos conductores iban fuertemente armados y llevaban documentación falsa proporcionada por un cómplice de la Guardia Civil. 


\section{Antropología del Género. Identidad sexual y géneros alternativos: un estudio sobre la homosexualidad femenina.}

$M^{a}$ Concepción Unanue Cuesta

Director: Dr. Óscar Fernández Álvarez

Tesis doctoral defendida el 21 de enero de 2016

El lesbianismo es una realidad muy desconocida a nivel social y siguiendo la línea de autores/as como Fuss (1999), Francisco, Andrea y Moliner (2011), Trujillo (2009), Suárez Briones (2013), Sanfeliú (1996) o Platero (2009), nos atreveríamos a decir que incluso a nivel de investigaciones, y no porque en los últimos tiempos no exista un creciente interés por investigar y acercarse a esta realidad, desde muy diversas disciplinas. Más bien diríamos que una de las dificultades que tiene realizar una investigación que aborde lo lesbiano, es la invisibilidad de las lesbianas y el difícil acceso ellas, fuera de los grupos de activismo.

Y con respecto a la investigación, como la mayoría de los trabajos desde diferentes perspectivas sobre el tema en los últimos 10 años, siguiendo a Sala (2008), Osborne (2012) y Mira (2004), podríamos decir que son desarrollados por parte de las propias lesbianas, y la mayor parte de estas investigaciones tienen una motivación común de sus autoras, empoderar al colectivo devolviéndole la voz que siempre ha debido tener para recuperar su historia, estructurar su biografía, y hacerse visibles desde su persona, que sean las propias voces lesbianas las que hablen, evitando que su historia y su realidad, sean "secuestradas" e interpretadas por quienes de manera más o menos activa y de manera más o menos consciente colaboran a su invisibilización y a “ocupar" sus propias realidades lésbicas.

Por otra parte, la diferencia de los contextos en los que estas personas viven, provoca una gran interacción en las redes sociales, chats, foros temáticos, como realidad alternativa a la que acceder para obtener información, socializarse, plantear dudas, conocer gente con la que poder salir y hablar, en definitiva socializarse en un contexto seguro para ellas.

Según proponen entre otros/as Aparici (1996), Arriazu (2007) o Hine (2004) si en todo trabajo de campo es necesario que el/la investigador/a sea capaz de adaptarse a la realidad de su grupo objeto de estudio, en este caso es necesario además que sea capaz de conocer y manejar las nuevas tecnologías que estas personas utilizan en su vida diaria para establecer vínculos y relacionarse. Por ello cobran una gran importancia las nuevas tecnologías como "contexto social" y como "contexto geográfico virtual". 
Además de conocer y manejar los contextos cibernéticos, en los que las lesbianas se relacionan, interactúan, preguntan dudas, hacen amistades y usan para tener algún referente o grupo de ellos que les haga más fácil el propio desarrollo personal, tendremos que aplicar herramientas profesionales compatibles con la recopilación de datos e información en internet, ser capaces de aplicar la denominada "etnografía virtual”, que nos permita investigar y llegar a un análisis de las realidades.

La invisibilización de la realidad lésbica es un círculo viciado que se retroalimenta, debido a ella, apenas hay referentes reales, por lo que los estereotipos son creados de forma artificial, en base a un imaginario que carece de base cierta, o incluso creados con muy diversas intenciones (industria del porno, control social, señas de identificación lésbica...). Pero a su vez estos estereotipos producen una opinión social que nada tiene que ver con el colectivo de lesbianas, lo que refuerza la estigmatización social y a su vez el deseo de estas personas para no ser identificadas como tales. Pero sin lesbianas que den el paso y se muestren con libertad, no podemos tener referentes reales, que retiren los estereotipos creados Esteban (2004), Gauntlett (2002), Platero (2009).

Los medios de comunicación con las construcciones de imágenes y las representaciones que hacen de las lesbianas a través de los personajes en series, webseries y películas, no son desde luego el mejor lugar en el que buscar y aprender, más bien, me atrevería a decir que todo lo contrario. La televisión como medio de comunicación más consumido, tiene gran influencia en los procesos de socialización y por tanto sería un entorno ideal para rastrear el discurso social y el imaginario colectivo, cuestión que abordaremos en esta investigación con el análisis de las series y películas más referidas por las participantes, como sostienen entre otros/as Chatman (1990), Berger y Luckmann (1978), Fiske (1997), Platero (2008), González (2011).

Forés \& Grané (2008), Turkle (1997), Giddens (1992), Dancecy (1990), entre otros/as sostienen que la falta de referentes reales no solo perjudica a la sociedad en su conjunto, puesto que ignoran una parte de la diversidad, perjudica y mucho a otras lesbianas que están en la etapa de asunción de su propia identidad, que se encuentran fuera de lugar, que se sienten mal o que incluso piensan que tienen una enfermedad mental, como he podido comprobar a raíz de los testimonios de algunas de las personas que han accedido a participar en la parte empírica de este trabajo.

Esta falta de visibilidad, se refleja en una falta de representación en los grupos LGTB+, donde siguiendo la tónica social, los espacios, los turnos y recursos están en manos de los gais, quienes a pesar de ser gais, son hombres y conservan las ventajas 
provenientes de las masculinidades hegemónicas Giddens (1992).

La forma en la que se desarrolla la investigación tiene la intencionalidad de poner en el centro a las lesbianas como auténticas y únicas protagonistas, de tener en cuenta sus aportaciones y su información en todo momento, para que los resultados sean lo más representativos posible de sus inquietudes y demandas, y no solamente una interpretación, o un análisis desde fuera, cuestión de la que se quejaron desde el primer momento las personas que aceptaron participar en la investigación, y por la que rehúsan participar en estudios.

Estas mujeres -incluso desde antes de definirse como lesbianas-, han sufrido una doble o múltiple discriminación, una por su condición de mujer, otra por su orientación sexual, y varias que pueden añadirse por diversas condiciones (etnia, clase social, diversidad funcional, lugar de residencia...) (De Lauretis, 1993). Este hecho se ha materializado, junto con muchos otros, en una invisibilidad que se extiende a casi todos los ámbitos de la sociedad. Sin embargo, desde hace unas décadas, el movimiento activista lésbico ha luchado por visibilizarse en nuestra sociedad, dentro y fuera de los movimientos gais. Este tipo de activismo ha pasado por diferentes etapas y reivindicaciones hasta llegar al momento actual, caracterizado, en general, por una gran agitación social y política que se extiende, sin duda, a toda nuestra sociedad.

Encontramos mucha bibliografía sobre homosexualidad, (la mayoría referente exclusiva, o casi exclusivamente, a la homosexualidad masculina), también encontramos mucha bibliografía sobre cuestiones de género y teorías queer (durante los últimos años con una mayor presencia, aunque todavía limitada, de autoras españolas). Específicamente en cuanto a identidades lésbicas, encontramos una relativamente amplia bibliografía, aunque, por supuesto, mucho menor que aquella que tiene por objeto a los hombres homosexuales; sin embargo, cuando unimos lesbianismo y antropología, activismo o cambio social, medios de comunicación o con ciberespacio, la literatura al respecto se ve bastante reducida, siendo, en la mayoría de los casos, una bibliografía editada por asociaciones u organizaciones LGTB+.

El trabajo consta de dos partes más amplias que son el Marco Teórico y la Investigación Empírica, dentro del Marco Teórico hay varios capítulos que responden a una revisión bibliográfica y documental, desde la que se intenta dar una base teórica a la parte empírica. La Investigación Empírica refleja el trabajo de campo propiamente dicho.

Dentro del Marco Teórico tenemos: una revisión del estado de la cuestión, 
conceptos básicos que ayudan a situarnos para abordar el posterior análisis bibliográfico, también contienen un breve repaso del género y los estudios comparativos de etnografías a través de la antropología.

Se analiza brevemente la relación entre cultura y relaciones sexuales entre mujeres, desde la antropología.

Para pasar finalmente a un breve repaso por el lesbianismo desde el punto de vista histórico y geográfico.

Se revisan:

El desarrollo de la identidad de la persona, analizando los principales modelos de desarrollo identitario.

Las principales aportaciones científicas para la despatologización de la homosexualidad/lesbianismo.

El concepto de homofobia/lesbofobia, los tipos de homofobia/lesbofobia existentes y la clasificación en función del contexto en el que tiene lugar.

Se realiza un análisis de la identidad lésbica, a través del cuerpo, de la experiencia, de las identidades naturales y las sexualidades normativas frente a las alternativas periféricas, para llegar a la visión de identidad lesbiana como movimiento de acción, se hace un breve recorrido por los movimientos lesbianos organizados del Estado español, para terminar analizando el papel de la identidad lesbiana como eje de resistencia y organización política.

Se realizó una revisión de la dicotomía fem y butch, para posteriormente analizar la rebelión de lo lesbiano frente a la heteronorma, a través de las ficciones, el lenguaje y la deconstrucción de la heteronormatividad desde su epicentro (falocentro).

Una revisión de los discursos mediáticos sobre el amor, la atracción y sus modelos, además de analizar los espacios "on line", la identidad digital, las redes sociales, las app, las nuevas tecnologías, y la incidencia que pueden tener en la propia identidad.

Se plasma el análisis de las series, webseries y películas visionadas, para trazar un perfil del personaje lesbiano predominante.

También se analizan a través de la información aportada por las participantes cuestiones como la tipología de lesbianas, lesbofobia, referentes y visibilidad lésbica, espacios de ocio e internet.

Se realiza la verificación de las hipótesis. Utilizando la información de las 
participantes y el análisis de las hipótesis, para realizar una breve conexión entre el marco teórico y la investigación empírica.

Finalmente se enuncian las conclusiones y se plasman unas líneas de investigación futuras, que ya se están trabajando.

En último lugar aparece la bibliografía de referencia, usada en la tesis, recogida a lo largo de varios años de interés investigador por el tema.

\section{BIBLIOGRAFÍA CITADA}

APARICI, R. (coord.) (1996). La revolución de los medios audiovisuales. Educación y nuevas tecnologías. Madrid: Ediciones La Torre.

ARRIAZU MUÑOZ, R. (2007). “¿Nuevos medios o nuevas formas de indagación?: Una propuesta metodológica para la investigación social on-line a través del foro de discusión". "FQS" Forum: Qualitative Social Research/Sozialforschung, vol. 8, $\mathrm{n}^{\circ} 3$.

BERGER, P.L. \& LUCKMANN, T. (1978). La construcción social de la realidad. Madrid: Amorrortu-Murguia.

CHATMAN, S. (1990). Historia y discurso. La estructura narrativa en la novela y en el cine. Madrid: Taurus.

DANCEY, C. P. (1990). "Sexual orientation in women: an investigation of hormonal and personality variables". Biol Psychol, 30 (3), pp. 251-264.

DE LAURETIS, T. (1993). "Sujetos excéntricos: La teoría feminista y la conciencia histórica". En Cangiano, M. y Du Bois, L. (eds.). De mujer a género: teoría interpretación y practica feminista en las ciencias sociales. Buenos Aires: Centro Editor de América Latina.

ESTEBAN, MáL. (2004). Antropología del cuerpo. Género, itinerarios corporales, identidad y cambio. Barcelona: Edicions Bellaterra.

FISKE, J. (1997). Television culture. London: Routledge.

FOUCAULT, M. (1978). Historia de la Sexualidad: 1, 2 y 3. La voluntad del saber. Madrid: Siglo XXI Editores.

FRANCISCO, A. y MOLINER, L. (2011). "Porque la visibilidad importa. Una propuesta para trabajar la diversidad sexual en la ESO a través de la educación en medios". Revista de Educación Inclusiva, 2, pp. 147-168. 
FORÉS, A. y GRANÉ, J. (2008). La resiliencia. Crecer desde la adversidad. Barcelona: Plataforma Editorial.

FUSS, D. (1999). "Dentro/Fuera". En Carbonell, N. y Torras, M. (eds.). Feminismos literarios. Madrid: Arco Libros.

GAUNTLETT, D. (2002). Media, Gender and Identity: An Introduction. New York, NY: Routledge.

GIDDENS, A. (1992). La transformación de la intimidad. Sexualidad, amor y erotismo en las sociedades modernas. Madrid: Cátedra.

GONZÁLEZ, C. (2011). "Visibilidad y diversidad lésbica en el cine español. Cuatro películas de la última década". Icono 14. Revista de Comunicación y Nuevas Tecnologías, 9, pp. 221-255.

HINE, C. (2004) Etnografia virtual. Barcelona: Editorial UOC. Colección Nuevas Tecnologías y Sociedad.

MIRA, A. (2004). De Sodoma a Chueca: historia cultural de la homosexualidad en España 1914-1990. Madrid: Egales.

OSBORNE VERDUGO, R. (2012). Mujeres bajo sospecha. Memoria y sexualidad 1930-1980. Madrid: Fundamentos.

PLATERO, R.(L.) (2008). "Las lesbianas en los medios de comunicación: madres, folclóricas y masculinas". En Platero, R. (L.) (coord.). Lesbianas. Discursos y representaciones. Madrid: Melusina, pp. 307-338.

PLATERO, R.(L.) (2009). “La construcción del sujeto lésbico”. LES Online, 1 (1), pp. 36-44.

SALA, A. y DE LA MATA BENÍTEZ, M. (2008). "La construcción dialógica de la identidad lésbica”. En García Jiménez, A., Núñez Puente, S. y Pérez-Amat, R. (coords.). Comunicación, identidad y género. Madrid: Fragua. Vol. 1, pp. 181191.

SANFELIÚ, L. (1996). Juego de Damas. Aproximación Histórica al Homoerotismo Femenino. Málaga: Ed. Atenea.

SUÁREZ BRIONES, B. (2013). Las lesbianas (no) somos mujeres. En torno a Monique Witting. Vigo: Suárez Briones

SUÁREZ BRIONES, B. (2014). Feminismos lesbianos y queer: Representación, visibilidad y políticas. Madrid: Plaza y Valdés. 
TURKLE, S. (1997). La vida en la pantalla: la construcción de la identidad en la era de internet. Barcelona: Paidós.

TRUJILLO, G. (2009). "Del sujeto político la Mujer a la agencia de las (otras) mujeres: el impacto de la crítica queer en el feminismo del Estado español". Política y Sociedad, 46 (1), pp. 161-172.

WITTING, M. (1980). Pensamiento heterosexual y otros ensayos. Barcelona: Egales. 

ISSN \เดЬ-0300

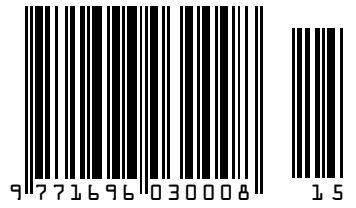

Sección I. MONOGRÁFICO. J.M. Bartolomé Bartolomé y M. García Fernández (Coords.) PRESENTACIÓN: CONSUMOS DE APARIENCIA EN LA CASTILLA MODERNA

BARTOLOMÉ BARTOLOMÉ, Juan Manuel, GARCÍA FERNÁNDEZ, Máximo. Presentación: Consumos de apariencia en la Castilla moderna

BLANCO CARRASCO, José Pablo. Sedas, rasos y damascos en la casa del Conde de Benavente (C. 1533)

GARCÍA HERAS, Víctor Alberto. El pan y el oro. Consumo diferenciado en la ciudad de Cuenca durante la guerra de sucesión española

GIORGI,Arianna. Sastres y roperos en Madrid. La imagen cotidiana de la moda del siglo XVIII

GARCIIAFERNÁNDEZ, Máximo. Vestidos pobres: consumos estancados. Valladolid en el siglo XVIII

BARTOLOMÉ BARTOLOMÉ, Juan Manuel. Vestir los cuartos y el cuerpo en el clero regular masculino: Ios canónigos de San Isidoro de León(1700-1825)

BIRRIEL SALCEDO, Margatita M. ¿Un consumo imprescindible? El traje femenino en las cartas de capital del Valle de Lecrín (1730-1770)

CRESPO SÁNCHEZ, Francisco Javier. Vestidos y adornos: la crítica a las apariencias externas a través de la prensa española (finales del siglo XVIII - siglo XIX)

ROSO DIAZ, José. Vestimenta, moda y sociedad en la comedia española de buenas costumbres

\section{SECCIÓN II. ESTUDIOS}

FERNÁNDEZ MENÉNDEZ, Mercedes. La respuesta patronal durante la Restauración ante los accidentes laborales en una empresa minera. El caso de la SociedadAnónima Minas de Riosa (Asturias, 1899-1916)

RODRIGGUZZ YUNTA, Luis. Difusión y evaluación de la investigación histórica en la era digital: revistas españolas y bases de datos

\section{SECCIÓN III. INVESTIGADORES NOVELES}

LI, CHENGUANG. "A vos el poderoso y muy estimado Rey de la China". Primera Embajada Regia de Felipe /I con destino a la China de la dinastia Ming: origen, preparación y abandono

\section{SECCIÓN IV. RESEÑAS YNOTICIAS BIBLIOGRÁFICAS}

GARCÍA HURTADO, Manuel-Reyes y REY CASTELAO, Ofelia (eds.), Fronteras de agua. Las ciudades portuarias y su universo cultural (siglos XIV-XXI), por María José PÉREZÁLVAREZ

APAOLAZA LLORENTE, Dorleta, Los bandos de buen gobierno en Cuba. La norma y la práctica (1730-1830), por Jesús PANIAGUAPÉREZ

\section{SECCIÓN V. Informaciones}

BARRIONUEVOALMUZARA, Isabel. La fotografia en León (1839-1900). Tesis doctoral defendida 5-febrero-2016

GARCIA FUERTES, Arsenio. La decisiva participación de los $6^{\circ}$ y $7^{\circ}$ ejércitos españoles en el triunfo aliado en las campañas de 1811 y 1812 durante la Guerra de la Independencia. Tesis doctoral defendida 15-enero-2016

LAGARTOS PACHO, Francisco Javier. Población, sociedad y familia en Tierra de Campos leonesa. La comarca de Sahagún en el s. XVIII. Tesis Doctoral defendida 21-enero-2016

MARTÍNEZ PÉREZ, David. Construyendo la democracia. Tardofranquismo, transición política y la cuestión autonómica en la provincia de León (1962-1984). Tesis doctoral defendida 28-enero-2016

REVILLACASADO, Javier. La economia de posguerra en la provincia de León (1937-1953): El Servicio Nacional del Trigo, los molinos y las fábricas de harinas. Los años del hambre y del estraperlo. Tesis doctoral defendida 19-enero-2016

UNANUE CUESTA, Ma Concepción. Antropología del Género. Identidad sexual y géneros alternativos: un estudio sobre la homosexualidad femenina. Tesis doctoral defendida 21-enero-2016 